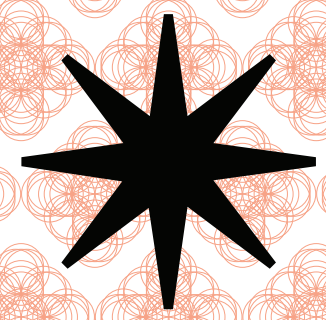

вопросы

\author{
перевода
}

и восприятия

Eva Kudrjavceva Malenová Maria Nenarokova

Paulina Wójcikowska-Wantuch Giulia De Florio 



\title{
Сказка - вопросы перевода и восприятия
}

\author{
Eva Kudrjavceva Malenová \\ Maria Nenarokova \\ Paulina Wójcikowska-Wantuch \\ Giulia De Florio
}

Masaryk University Press

Brno 2019 
Reviewers

Mgr. Elena Vasilyeva, CSc.

prof. Irina Mineralova, CSc.

(C) 2019 Masaryk University Press

ISBN 978-80-210-9344-7

https://doi.org/10.5817/CZ.MUNI.M210-9344-2019 


\section{Содержание}

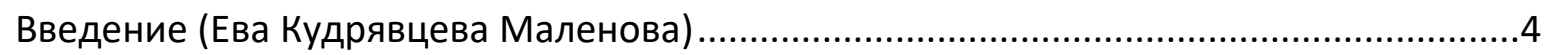

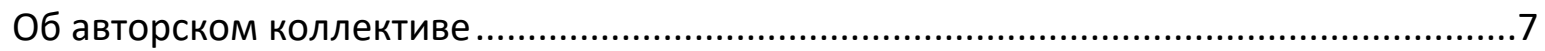

РУССКАЯ НАРОДНАЯ СКАЗКА ЗА РУБЕЖОМ И ЗАРУБЕЖНАЯ СКАЗКА

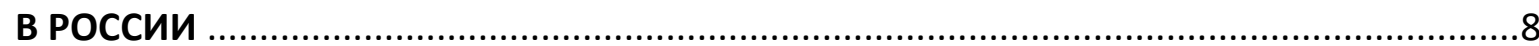

Русская народная сказка в англоязычном контексте - трудности перевода

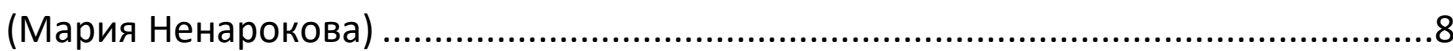

Западноевропейская народная сказка в России: издание бытование,

восприятие (чешские, польские, итальянские, английские сказки)

(Мария Ненарокова)

РУССКАЯ ЛИТЕРАТУРНАЯ СКАЗКА ЗА РУБЕЖОМ И ЗАРУБЕЖНАЯ СКАЗКА

В РОсСИи (Ева Кудрявцева Маленова) ….............................................................55

От перевода к переложению и обратно (Ева Кудрявцева Маленова)...................56

Итальянаский оригинал и русский перевод - Пиноккио и Буратино

в польском контексте (Паулина Вуйциковска-Вантух) ........................................57

Итальянский оригинал и русский перевод - Пиноккио и Буратино

в чешском контексте (Ева Кудрявцева Маленова) ...............................................80

La fiaba letteraria russa in Italia: traduzione e ricezione - Русская

литературная сказка в Италии (Джулия Де Флорио) ..............................................94

Сказочная повесть в творчестве Владимира Кантора

(Паулина Вуйциковска-Вантух) .......................................................................110

Заключение (Ева Кудрявцева Маленова) .................................................................126

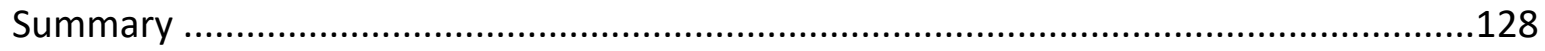

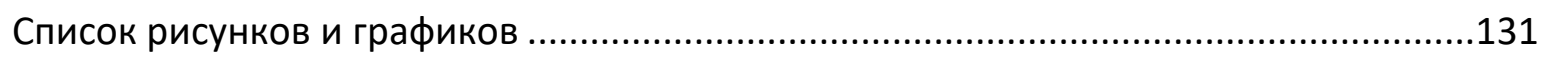

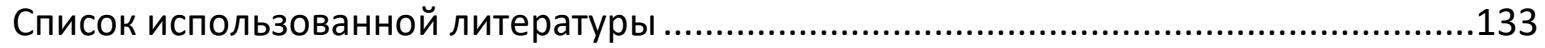

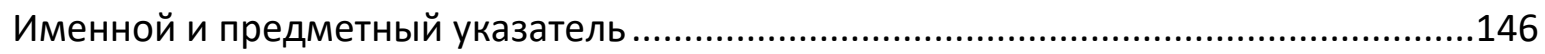




\section{Введение}

\section{(Ева Кудрявцева Маленова)}

Центральной темой данной монографии явлется один из древнейших и одновременно один из самых современных жанров художественной литературы сказка. Она до сих пор является удивительно актуальной практически во всем мире, что стало причиной объединения четырех авторов данной монографии. Таким образом, в монографии рассматривается сказка в разных языковых контекстах русском, чешском, польском, итальянском, и отчасти английском. Сказка рассматривается с точки зрения перевода, благодаря которому она может существовать в иноязычной среде, т. е. может произойти ее восприятие.

Сказкой как жанром, а также его истоками, традициями, определениями и т.д. занимались разные исследователи - из русскоязычных необходимо упомянуть: В. Проппа, Е. Мелетинского, М. Азадовского, Т. Леонову, В. Непомнящего, Э. Померанцеву, Е. Зубареву, Т. Полозову, И. Лупанову, Е. Неелова, И. Мотяшова, Л. Брауде, М. Липовецкого, Л. Овчинникову, В. Аникина, И. Минералову, И. Арзамасцеву и других.

Однако, традиционный жанровый подход в наше время предоставляет с исследовательской точки зрения лишь ограниченные возможности, потому что сказка как жанр исторически слишком долгое время развивается, она перенесла многие изменения, впитала черты других жанров и т. п. Отметим лишь важнейшие формальные изменения - от изначально устного народного творчества путь развития сказки вел, через записанные редакции (т. е. варианты) самих фольклорных текстов, котдельным авторским версиям народного творчества, которые постепенно, но все заметнее уходили от фольклорного источника и становились новым, самобытным вариантом изначального жанра, т. наз. литературной сказкой. Стоит особо отметить, что во второй половине XX века сказка, благодаря технологическому прогрессу, обрела новые возможности с подчеркнутой визуальной формой (фильмы, мультфильмы, компьютерные игры и т. д.). Таким образом, визуальная форма в наше время зачастую существует не только параллельно с текстом сказки в духе традиции книжных изданий с 19 века, но и заменяет письменную форму. Под влиянием всеобщего синтеза приближаются или стираются границы раньше отличавшихся жанров - например, в т. называемую 
«лирическую сказку» ${ }^{1}$ явно проникли черты притчи, басни, а также анекдота, аллегории, жанровой зарисовки и т. Д.

С течением времени менялось и предназначение сказки. Если изначально она предназначалась взрослым, затем рассматривалась преимущественно как жанр литературы для детей, то особенно в последнее время (со второй половины XX века) можно наблюдать тенденцию расширения ее читательской аудитории, т. е. возвращение сказки квзрослому читателю. Можно также говорить о двуплановости сказок и двойной адресации или «многоуровневой адресации» термин Е. М. Неелова - согласно которому «взрослый план содержания с большей или меньшей степенью проявленности присутствует, в сущности, в любом детском произведении» ${ }^{2}$, т. е. сказка предназначена не только для детей, но одновременно и для взрослых.

Следовательно, авторы данной монографии осознают, что именно длинный и разнообразный исторический путь сказочного жанра в комбинации с его актуальностью по сей день - являются причиной сложностей в его научном осмыслении. В данной монографии намеренно не представляется попытка нового жанрового определения. Главная цель данной книги - исследование возможностей существования сказочного жанра вне территории его происхождения или естественного распространения. Таким образом, обращается внимание на вопросы и возможности международного восприятия сказок. Давно доказано, что среди т. наз. бродячих сюжетов есть и сказочные. Они появлялись издавна в разных географических пространствах. Однако в данном исследовании обращается внимание не на бродячие сюжеты, а на тексты, которые передаются заведомо, т. е. намеренно переводятся и искусственно вводятся в другой языковой контекст. В данной монографии дается исследование русской сказки сквозь призму ее существования в контексте некоторых европейских стран - Польши, Чехии, Италии. С другой стороны, в исследование включается и обратный взгляд - т. е. контекст перевода зарубежных сказок на русский язык. Однако, необходимо подчеркнуть, что центральное место в монографии принадлежит русской сказке.

Целью нашей работы является не поиск нового теоретического определения сказки как жанра или ее комплексная систематизация, а выявление возможного

\footnotetext{
1 Л. Овчинникова определила данный вариант как «философская сказка» и далее уточнила «философско-лирическая сказка» (Овчинникова 2003, 112), однако термин «лирическая сказка» является более точным, не уводит внимание к другой дисциплине. Более о нем и его значении (Кудрявцева Маленова, 65-106).

2 НЕЕЛОВ, Е. М. Сказка и литература: судьба царевны-лягушки. Петрозаводск: Издательство ПетрГУ, 2011, c. 5.
} 
(не)совпадения восприятия в рамках разных языковых контекстов, т. е. русских сказок за рубежом и европейских сказок не только в России. В качестве материала были выбраны русские народные сказки и избранные западноевропейские народные сказки. В разделе литературной сказки на примере итальянского произведения К. Коллоди о Пиноккио, переложенного на русский язык А. Толстым под названием «Золотой ключик, или Приключения Буратино» рассматривается продуктивная тенденция русской литературной обработки и ее жизнеспособность вне русскоязычной территории (в польском и чешском контекстах) на протяжении 20 века. Отдельное внимание уделяется истории русской литературной сказки и ее восприятию в Италии. И наконец, рассматривается русская литературная сказка второй половины 20 века на материале сказочных повестей В. Кантора.

Главный тезис нашей работы вытекает из утверждения, что именно перевод играет для восприятия художественного произведения виноязычной среде ключевую роль и является первичным фактором. Без перевода восприятие текста ограничивается лишь владеющими языком знатоками зарубежной литературы. Однако предполагается, что качество восприятия (особенно положительное восприятие) зависит не только от перевода, а преимущественно от внетекстовых факторов. Поэтому попытаемся сравнить факторы восприятия оригинального итальянского произведения К. Коллоди ифакторы восприятия переложения А. Толстого в рамках разных языковых контекстов. Из вышеуказанного вытекает, что центральным является компаративистский метод, далее используются историкогенетический и историко-типологический методы, приемы целостного, текстологического анализа и интерпретации литературного произведения.

Коллективная монография состоит из трех частей:

1. Введения, в котором выясняются теоретические задачи, методы и цели, а также терминологические нюансы;

2. Главы, посвященной народной сказке;

3. Главы, посвященной литературной сказке.

Отделение и последовательность сказки народной (иногда называемой «фольклорной» или «традиционной») и литературной (иногда называемой «авторской») в монографии представляется необходимым по причине их основательного различия и логики исторического развития. 


\section{Об авторском коллективе}

Джулия Де Флорио, исследователь, преподаватель русского языка и русской литературы (ДФ)

Научные интересы: детская литература, гитарная поэзия, перевод

giulia.deflorio@unimore.it

Государственный университет Модены и Реджо Эмилии, Италия

Ларго Сант-Эуфемия 19, 41121 Модена, Италия

\section{Ева Кудрявцева Маленова, кандидат филологических наук (ЕКМ)}

Научные интересы: русская литературная сказка, Геннадий Цыферов, детская литература и вопросы ее международного восприятия

eva.malenova@gmail.com

Кафедра русского яз. и лит., Педагогический факультет, Университет им. Масарика, Чехия

ул. Поржичи 9, 60200 г. Брно, Чехия

Мария Ненарокова, доктор филологических наук (МН)

Научные интересы: перевод и переводоведение, английская, русская литература maria.nenarokova@yandex.ru

Институт мировой литературы им. А.М. Горького Российской академии наук (ИМЛИ РАН), Россия

ул. Поварская 25а, 121069 г. Москва, Россия

\section{Паулина Вуйциковска-Вантух, кандидат филологических наук (ПВ)}

Научные интересы: новейшая русская литература, жанр сказки в литературе, славянская мифология и фольклор

paulina.wantuch@filolozka.pl

Институт Иностранных Языков, Высшая Государственная Профессиональная Школа в Новом Сонче, Польша

ул. Кохановского 44, 33-100 Новы Сонч, Польша 


\title{
РУССКАЯ НАРОДНАЯ СКАЗКА ЗА РУБЕЖОМ И ЗАРУБЕЖНАЯ СКАЗКА В РОССИИ
}

\author{
Русская народная сказка в англоязычном контексте - трудности \\ перевода \\ (Мария Ненарокова)
}

\section{Ранние переводы русских сказок на английский язык.}

Традиция переводов русских сказок на английский язык насчитывает около 150 лет. Интерес кним объяснялся желанием англичан и американцев узнать культуру России, поскольку, по словам А. Н. Толстого, «Сказка - великая духовная культура народа, которую мы собираем по крохам, и через сказку раскрывается перед нами тысячелетняя история народа» (цит. по: Плотникова, Юйшина 2016, 8).

Впервые англоязычная читающая публика познакомилась с русскими сказками в 1873 г., когда известный английский ученый ипереводчик Уильям Ральстон-Шедден Ральстон (1828-1889) издал сборник под названием Russian FolkTales (Nisbet Bain 1915, 5). Источником для него послужило собрание сказок А. Н. Афанасьева, а также некоторых других собирателей фольклора. Как переводчик написал в предисловии к изданию 1873 г., его «главной целью было знакомство английских читателей с русской народной сказкой» ${ }^{3}$ (Ralston 1873, X). По мнению Ральстона, сказки необходимо было «передавать настолько близко к тексту, насколько это было возможно» (Ralston 1873, X), ведь «в зарисовке с натуры более всего требуется точность. "Нетронутая” фотография в определенных случаях гораздо более предпочтительна, чем та, над которой усердно “поработали”» (Ralston 1873, XI). Критики оценили русские сказки в переводе Рольстона как «дикие, кровожадные и ужасные» (McCrimmon 1988, 183). Возможно, поэтому впоследствии переводчики шли по пути адаптации фольклорных текстов. Так, в 1892 г. появился еще один сборник русских сказок, переведенных на английский язык. Автором перевода был Роберт Нисбет Бейн (1854-1909), историк и лингвист, сотрудник Британского Музея. Он обратился не к афанасьевскому собранию, а к изданию П.Н.Полевого, который опубликовал свои «Народные русские сказки» (1874), «смягчив грубость и сгладив встречающиеся время от времени шероховатости этих очаровательных историй» (Nisbet Bain 1915, 5). Такой подход к изданию русских народных сказок сохраняется

\footnotetext{
${ }^{3}$ Все цитаты, кроме оговоренных особо, являются переводами, выполненными автором статьи.
} 
до сих пор. Так, например, в предисловии к учебному пособию «Учим русский через сказку» (2005), которое фактически является двуязычным изданием сказок, составители сразу определяют свой подход ктекстам: «Удаляя из исконного сказочного текста грубые выражения и вульгаризмы (зачастую присущие фольклору), авторы оставили в неприкосновенности характерные словосочетания, идиоматические выражения, синтаксические конструкции, которые и создают своеобразие и неповторимость русского сказочного повествования» (Блох 2005, с.3-4).

Обзор английских переводов русских сказок, выполненных в XX- нач.XXI вв., выявил проблемы, с которыми сталкиваются переводчики, когда они приступают к работе над текстами такого рода. Одна из проблем перевода народной сказки на иностранный язык, как кажется, состоит втом, что не существует одного, неизменяемого ее текста, так как она может быть записана в нескольких вариантах. Составители сборников сказок выбирают тот вариант, который кажется им наиболее уместным для именно этого издания. С другой стороны, из текста сказки могут исключаться диалектные слова, указывающие на место ее записи, язык ее может приближаться клитературному. Текст сказки может не только очищаться от просторечий и диалектизмов, но и сокращаться, однако и такой адаптированный текст может быть переведен на иностранный язык. В отличие от авторской, литературной сказки, перевод которой можно сравнительно просто проанализировать предложение за предложением, сравнивая его с оригиналом, перевод фольклорной сказки, как кажется, нужно анализировать не сплошь, а сосредоточиться на особенностях, сохраняющихся хотя бы в каком-то виде в переводах всех ее вариантов.

\section{Перевод названия сказки.}

Название произведения является одной из его сильных позиций. Его можно рассматривать как краткое изложение того, о чем рассказывается в сказке, например, «Поди туда не знаю куда - Найди то не знаю что» - Go I know not whither Fetch I know not What (Nisbet Bain 1915, 7). Однако и название сказки может существовать в разных вариантах. Таков случай сказки «Перышко Финиста Ясна Сокола», записанной А.Н.Афанасьевым под этим названием в середине XIX в. Сказка неоднократно публиковалась в сборниках, ориентированных на детскую аудиторию, ее текст редактировался. В переводах мы встречаем варианты названия. Точнее всех название этой сказки перевел Р.Нисбет Бейн: The Little Feather of Fenist the Bright Falcon (Nisbet Bain 1915, 7). Как видим, переводчик постарался передать даже 
значение уменьшительно-ласкательного суффикса «-ышк-», переведя «перышко» как The Little Feather, хотя слова с уменьшительно-ласкательными суффиксами не легко переводятся на английский язык. Далее название сказки видоизменяется: The Feather of Fenist the Falcon (Wheeler 1957, 176), Finist the Bright-Eyed Falcon (Finist 1979), Finist the Bright Falcon (Russian Folk Tales 1987, 125), Finist the Falcon (Finist 2000). Как видим, переводчики идут по пути упрощения названия, перестройки его по модели «название - имя главного персонажа».

Такие названия характерны как для русских - «Терешечка» (Афанасьев 1984, онлайн), «Князь Данила Говорила» (Афанасьев 1984, онлайн), «Никита Кожемяка» (Афанасьев 1984, онлайн), так и для английских сказок: Jack Hannaford (World of Tales, 1, онлайн), Childe Rowland (World of Tales, 2, онлайн), Earl Mar's Daughter (World of Tales, 3, онлайн). Переводчики постепенно избавились и от эпитета «ясен/ясный», видимо, потерявшего первоначальное значение для современного читателя ипереводчика. Водном случае «ясен/ясный» понято как «ясноокий/ясноглазый» - Bright-Eyed (Finist 1979). В русском языке «ясные глаза» понимаются как «светлые» (по цвету), «с искренним выражением», но существуют и ассоциации с хорошим зрением. В то же время зоркость как качество в понимании русского человека характерна для хищных птиц - сокола и орла. Стоит отметить, что переводчики обращают внимание на прозвище героя, но не на его имя - Финист, которое, как полагают, является вариантом слова «феникс» - «птица, сжигающая себя и возрождающаяся из пепла» (Максимович 1992, 327). В сочетании с именем прилагательное «ясный» может означать «огненный». Тем не менее, даже не понимая, что стоит за именем «Финист Ясный Сокол», переводчики создали название, используя аллитерацию: Finist/Fenist the Falcon, что соответствует поэтике английского фольклора. Среди английских сказок находим Tom Tit Tot (World of Tales, 4, онлайн), Nix Nought Nothing (World of Tales, 5, онлайн), The Stars in the Sky (World of Tales, 6, онлайн) и другие.

Одной из первых русских сказок, известных англоязычному читателю, стала сказка «Морозко». Она была включена У.Р.С.Ральстоном в его сборник Russian FolkTales еще в 1873 г. и с тех пор переводилась неоднократно. Первый переводчик сказки, У. Ральстон, перевел название дословно - Frost (Ralston 1873, 214), а в сборнике Р. Нисбет Бейна встречаем уже транслитерацию - Morozko (Nisbet Bain $1915,17)$, поскольку «Морозко» является именем одного из главных героев сказки, пусть это и мифологический персонаж. В переводческом комментарии к названию сказки Р.Нисбет Бейн отмечает, что «Джек Фрост (Jack Frost), является, пожалуй, самым близким английским эквивалентом» главного героя сказки (Nisbet Bain 1915, 17). Этой же традиции перевода придерживается Пол Уильямс, в переводе которого 
сказка была опубликована в 2000 г. С другой стороны, шотландский фольклорист Эндрю Лэнг, издававший сборники, в которые входили сказки разных народов, предпочел нейтральный перевод King Frost (Andrew Lang, онлайн), возможно, для того, чтобы достичь единообразия в переводах. Советская переводчица Ирина Железнова перевела «Морозко» как Father Frost (Words of Wisdom 2000, 31), использовав имя, имеющее более широкие культурные ассоциации, поскольку россиянин XX в. представляет себе героя по имени Father Frost не как некий персонаж славянского фольклора (Мифы народов мира 2008, 176), а как Деда Мороза, участника новогодних представлений, приносящего детям подарки. Американский переводчик Н.Гутерман перевел название сказки по аналогии - Jack Frost (Guterman 1945, 7), использовав имя персонажа английского фольклора и тем самым привнеся в перевод ассоциации с культурой принимающего языка.

Название знаменитой сказки «Царевна-Лягушка» имеет несколько вариантов в английских переводах: название, образованное по модели «сказка о...» - Tale of the Frog Tsarevna (Zamchuk 1998, 35), а также более короткие названия - The FrogTsarevna (Nisbet Bain 1915, 118), The Frog Tsarevna (Перышко Финиста 2000, 40), The Frog Princess (Russian Folk Tales 1987, 99). Последнее название отражает тенденцию перевода по аналогии, когда слово, отсутствующее в английском языке и обозначающее русскую реалию, заменяется словом, обозначающим сходную реалию в английской культуре (tsarevna заменяется на princess). Исключение составляет название Three Golden Arrows (Yoch Schwab 1934, 15), полученное в процессе целостного преобразования. Сказка получила новое название, выбрать которое позволил один из ключевых моментов ее сюжета: царевичи пускают золотые стрелы в разные стороны, чтобы найти себе жен. Можно предположить, что переводчик хотел сделать издание более понятным ипривлекательным для читателей и создал новое название в традициях английского фольклора, имея в виду такие сказки, как The three heads of the well (World of Tales, 7, онлайн), Three Feathers (World of Tales, 8, онлайн), The Three Cows (World of Tales, 9, онлайн) и похожие на них.

\section{Перевод имен персонажей.}

В качестве названий сказок нередко используются имена, которые потом мы находим и в текстах. Это неизменяемые элементы текста, которые сохраняются в переводах, выполненных в разное время. В большинстве своем имена сказочных существ и героев связаны с культурой имифологией русского народа, они уникальны, поэтому чаще всего при их передаче переводчики прибегают 
к транслитерации. Так, в переводах Роберта Нисбет Бейна встречаем царя по имени Umnaya Golova - «Умная Голова» (Nisbet Bain,1915, 41) - и его дочерей - Neotsyenaya - «Неоценная» (Nisbet Bain 1915, 41) и Beztsyenaya - «Бесценная» (Nisbet Bain 1915, 41). Поскольку для английского читателя эти имена оказываются набором звуков, переводчик сопровождает текст подстрочным комментарием, объясняя имена царской семьи как Wise Head (Nisbet Bain 1915, 41), Not to be priced (Nisbet Bain 1915, 41), Without price (Nisbet Bain 1915, 41) соответственно. Написание английских вариантов имен заставляет думать о транслитерации, так как, например, в слове Golova передаются обе буквы «о», хотя ударение при произношении падает на последний слог. Интересно, что в оригинале сказки имена царевен звучат иначе: «царевна прекрасная, которую назвали Неоценой» (Полевой 1874, 25), «другая дочь, столько же прекрасная, которую назвали Безценой» (Полевой 1874, 25). Далее П.Н. Полевой в именительном падеже пишет «Неоцена» и «Безцена». Переводчик же был введен взаблуждение формой творительного падежа существительных женского рода 1-ого склонения, совпадающей с такой же формой прилагательных. Поэтому в его тексте царевны называются Neotsyenaya - «Неоценная» и Beztsyenaya - «Бесценная».

Интересен случай «Сказки о Горе-Горинском». Имя одного из главных героев сказки, Горя, которое преследует крестьянина, вынесено в название сказки - The Story of Gore-Gorínskoe (Nisbet Bain 1915, 61), однако переводчик не перегружает текст длинным и непонятным словом и не приводит подстрочный комментарий. Он переводит имя персонажа как Woeful Woe (Nisbet Bain 1915, 63) - букв. «Горькое Горе». Перевод можно считать в высшей степени удачным, поскольку, с одной стороны, Р. Нисбет Бейну удалось для передачи имени воспользоваться тем же художественным средством, что и в русской сказке, то есть аллитерацией, с другой, вписать перевод в английскую сказочную традицию.

Часто сказочные персонажи наделяются христианскими именами. Так, встречаем в русских сказках царевичей Димитрия (Dimitry) (Nisbet Bain 1915, 119), Василия (Vasily) (Nisbet Bain 1915, 119), Алексея (Alexei) (Nisbet Bain 1915, 123), Ивана (Ivan) (Nisbet Bain 1915, 119; Ralston 1873, 85; Yoch Schwab 1934, 18), царевен Настасью (Nastasia) (Nisbet Bain 1915, 133), Марию (Marya) (Ralston 1873, 85), Ольгу (Olga) (Ralston 1873, 85), Анну (Anna) (Ralston 1873, 85), Елену (Helena) (Wheeler 1957, 123). Стоит отметить, что имя царевны приводится в его народном варианте: «Анастасия» - «Настасья». Малоизвестный в России испанский святой - св.муч. Афраний - дал имя другому персонажу, но иэто имя отражает просторечное произношение - царь Афрон Афронович (Afron Afronovich) (Nisbet Bain 1915, 119). Если сказка повествует о крестьянах, то имена героев соответствуют их социальному 
положению: Danilo...Gavrilo... Ivan (Wheeler 1957, 67); Pakhom, Thomas, and Ivan (Nisbet Bain 1915, 133). И здесь ведущим приемом передачи имени персонажа становится транслитерация.

Исключение составляет имя «Фома»: оно заменяется своей английской формой, причем в сказке «Фома Беренников» находим как полную форму имени Thomas Berennikov (Nisbet Bain 1915, 147), так и краткую - Thommy (Nisbet Bain 1915, 148).

Имена мифологических персонажей, как правило, переводятся: царевна Краса Несказанная называется у Р.Нисбет Бейна Loveliness-Inexhaustible (Nisbet Bain 1915, 96), а в анонимном переводе 1987 г. - Princess Lovely (Russian Folk Tales 1987, 138). Мужья царевен из «Сказки об Иване Царевиче иГуслях-Самогудах» называются «Чудище Лесное» - the Forest Monster (Nisbet Bain 1915, 51) - и «Чудище Морское» - the Sea Monster (Nisbet Bain 1915, 53).

В русских сказках есть герои, образы которых переходят из сказки в сказку: таковы Баба Яга, Кощей Бессмертный. Имя Бабы Яги, «самой страшной ведьмы в русских волшебных сказках» (Nisbet Bain 1915, 50), как писал о ней в переводческом комментарии Р. Нисбет Бейн, традиционно транслитерируется, однако только первый из переводчиков, У. Р. Ральстон, пишет его в два слова - Baba Yaga (Ralston 1873, 92). Дальнейшая переводческая традиция отдает предпочтение написанию через дефис (Finist 1979, 11), и это лишает знаменитую героиню одной из главных ее характеристик, старости. Хотя обычно имя Бабы Яги транслитерируется, однажды попадается и ее прозвище - оно переводится: «Костяная Нога» - bony-leg (Nisbet Bain 1915, 50). Сходная ситуация сложилась и в случае Кощея Бессмертного. Первый переводчик русских сказок на английский язык, У.Р.Ральстон, предлагает два варианта передачи имени этого персонажа, частью транслитерируя, частью переводя его: Koshchei the Deathless (Ralston 1873, 86), Immortal Koshchei (Ralston 1873, 97). Р. Нисбет Бейн транслитерирует и прозвище Кощея: Koshchei Bezsmertny (Nisbet Bain 1915, 124), а через несколько лет в книге А. Брылинской и Г. Смита находим и перевод слова «Кощей»: «Кощей Бессмертный» - The Deathless SkeletonMan (Brylinska, Smith 1919, 31). Американский переводчик Й. Шваб передал имя Кащея при помощи транскрипции и расшифровал прозвище, записав его в виде придаточного предложения Kaschei the One-Who-Cannot-Die (Yoch Schwab 1934, 26) «Кащей Тот-Кто-Не-Может-Умереть». Для XX в. характерно написание через дефис: Koshchei-the-Deathless (Russian Folk Tales 1987, 105).

Не всегда имена сказочных героев бывают понятны переводчику, поэтому появляются такие казусы, как Tsar-Morskoi the Sea-Ruler (Wheeler 1957, 87) - букв. «Царь-Морской Морской Правитель» в переводе П.Уилера, где Tsar-Morskoi 
понимается как имя персонажа. УА. Брылинской иГ. Смита, напротив, находим «Царь Морской» как The Sea-King (Brylinska, Smith 1919, 43) - «Морской Король».

Притом что обычными способами передачи имен персонажей в русских сказках являются транслитерация и перевод, в редких случаях встречаем использование калькирования. Например, в сказке «Летучий корабль» при помощи калькирования передается такое имя, как «Объедало» - Gobbler (Nisbet Bain 1915, 24). Имена «Скороход» - Swift-of-Foot (Nisbet Bain 1915, 26) - и «Стреляло» Marksman (Nisbet Bain 1915, 26) (букв. «меткий стрелок») - подбирались по аналогии.

\section{Перевод слов с уменьшительными суффиксами.}

Сложность для перевода представляют слова с уменьшительными суффиксами. Русский язык богат такими суффиксами, в то время как в английском их немного, и они не являются продуктивными, поэтому английским переводчикам приходится передавать значения уменьшительности, ласкательности, пренебрежения самыми разными средствами. Это отчетливо видно на примере обращений к различным персонажам. Так, обращение к старику менялось от Little Grandfather (Yoch Schwab 1934, 28) - «дедушка» к разговорному granddad (Finist 1979,5) - «дедушка»; к старушке, в частности к Бабе Яге: от dear little Granny (Nisbet Bain 1915, 50) - «милая бабуля» к нейтральному grandmother (Finist 2000, 26) - «бабушка»; к царю-отцу: от Little Father (Yoch Schwab 1934, 16) - «батюшка» к разговорному my beloved Dad «мой любимый папочка» (Finist 2000, 10).

Интересные примеры можно найти в сказке «Морозко» в переводе Р.Нисбет Бейна. Переводчик снабжает название сказки комментарием: Morozko. Caressing diminutive of Russian moroz (frost) (Nisbet Bain 1915, 17) - «Морозко. Уменьшительноласкательное [производное] от русского “мороз"». При помощи транслитерации Р. Нисбет Бейн передает уменьшительно-ласкательную форму от имени «Мороз» Morozushko (Nisbet Bain 1915, 18) - и прибавляет подстрочный комментарий: i.e darling Moroz (Nisbet Bain 1915, 17) - «то есть милый Мороз». Однако в сказке есть и более сложные по составу обращения к Морозу, передающие значение уменьшительности и ласкательности: Morozushko, little father (Nisbet Bain 1915, 18) «Морозушко, батюшка»; dear little father Morozushko (Nisbet Bain 1915, 18) «дорогой батюшка Морозушко», darling little pigeon mine, Morozushko (Nisbet Bain $1915,18)$ - «милый голубочек мой, Морозушко». Стоит отметить, что главным способом передать уменьшительность оказывается использование прилагательного little; теплые чувства передаются при помощи прилагательного dear - «дорогой, милый, любимый» - и существительного darling - «дорогой, любимый, душка». 
В другой сказке, в «Сказке о Горе-Горинском», герой обращается к Горю: darling little Woe (Nisbet Bain 1915, 64) - «дорогое Горюшко».

Так как имена сказочных героев обычно транслитерируются, они воспринимаются англоязычными читателями как целостные, присутствие в имени уменьшительноласкательного суффикса не отмечается. Имена героев при этом теряют положительную эмоциональную окраску: Аленушка - Alyonushka (Russian Folk Tales 1987, 93), Иванушка - Ivanushka (Russian Folk Tales 1987, 93), Марьюшка - Maryushka ( Finist 1979, 3). Отдельный случай представляет собой сказка «Крошечка Хаврошечка». Героиню называют уменьшительно ласкательным именем «Хаврошечка» (народный вариант имени «Феврония») - Khavroshichka (Brylinska, Smith 1919, 4), Havroshechka (Russian Folk Tales 1987, 92), при этом существительное «Крошечка» заменяется словами с общим значением «крошечный»: в одном случае Mite (Brylinska, Smith 1919, 4) - «крошечное существо», в другом сочетание прилагательных - диалектное, шотландское Wee - «крошечный» и нейтральное Little (Russian Folk Tales 1987, 92) - «маленький». В разных переводах сказки «Василиса Премудрая» встречаем ласковое обращение к девочке Василисе (Vasilisa) (Finist 2000, 23) - «Василисушка» как словосочетание little Vasilisa (Wheeler 1957, 50) и как транслитерацию русского Vasilisushka (Finist 2000, 23).

Встречаются в сказках и уменьшительные имена не с оттенком ласкового обращения, а скорее как варианты имен, употребляющихся в семье. Так отец трех могучих богатырей, рекомендуя их на службу царю, называет их уменьшительными именами. Р.Нисбет Бейн транслитерирует эти имена иприбавляет к каждому подстрочный комментарий: Zor'ka. Diminutive of Zorya, the Red Dawn (Nisbet Bain 1915, 31) - «"Зорька”. Уменьшительное от “Заря”, “Алая Заря”», Vechorka. Diminutive of Vecher, Evening (Nisbet Bain 1915, 31) - «"Вечорка". Уменьшительное от “Вечер”», Polunochka. Diminutive of Polunoch, Midnight (Nisbet Bain 1915, 31) - “Полуночка". Уменьшительное от “Полночь"».

Иногда в сказках возникает необходимость передать не только теплые чувства, но и пренебрежение, презрение, в случае знаменитой Избушки на Курьих Ножках подчеркнуть ее ветхость. В сказках Избушка воспринимается почти как живое существо. Существительное «избушка», имя нарицательное, становится иногда именем собственным и передается транслитерацией: And Ivan Tsarevich cried to it, "Izbushka! Izbushka! turn your back to the wood... (Nisbet Bain 1915, 50) - «И Иван Царевич крикнул ей: “Избушка! Избушка! поворотись клесу задом"...» Обычно небольшие размеры Избушки выражаются употреблением прилагательного little: a little hut (Nisbet Bain 1915, 32; Finist 2000, 24) - букв. «маленькая изба», но когда необходимо подчеркнуть внешне неприглядный вид лесной избушки, 
дополнительно используются прилагательные miserable - «убогий»: a miserable little hut on hen's legs (Wheeler 1957, 52) - «убогая избушка на курьих ножках»; wretched «жалкий»: a wretched little hut turning round and round on hen's legs (Nisbet Bain 1915, 50)- «жалкая избушка, все время поворачивающаяся кругом на курьих ножках».

Уничижительно в сказках характеризуются и некоторые герои из крестьян, которые на поверку оказываются либо мудрыми советчиками, либо главными героями сказки, причем на социальное положение персонажей указывает транслитерированное существительное «мужик/мужичок»: a miserable little muzhik (Nisbet Bain 1915, 25)- "убогий мужичок», little withered old grey-beard Muzhichek (Nisbet Bain 1915, 30) - «морщинистый седобородый старый мужичок».

Наконец, прилагательное little может использоваться в нейтральных контекстах, когда нужно подчеркнуть небольшой размер: a little ring (Nisbet Bain 1915, 38) - «колечко», a little frog (Yoch Schwab 1934, 17) - «лягушечка», my little doll (Wheeler 1957, 57) - «моя куколка».

\section{Перевод русских реалий.}

Еще одна группа слов представляет собой немалую трудность для переводчика: это - реалии, отражающие своеобразие жизни и культуры русского народа ине имеющие эквивалентов в других языках. Как показал анализ текстов сказок, переводчики выбирают один из двух путей: они либо разными способами передают русские реалии (транскрипция, транслитерация, калькирование), либо подыскивают аналоги в своем родном языке. В первом случае национальный колорит сохраняется, но текст подчас требует комментариев. Во втором случае текст становится нейтральным, иногда смысл текста искажается.

В каждой группе реалий есть подтверждение этого наблюдения. Так, например, в сказках находим денежные единицы rouble (Nisbet Bain 1915, 11) (транслитерация) - «рубль» и copeck (Nisbet Bain 1915, 44) (транскрипция) «копейка», но также и обозначение английской мелкой монеты, подобранное по аналогии, penny (Nisbet Bain 1915, 63) - «пенни, пенс, однопенсовик».

По сказкам можно представить себе общую структуру русского общества (до 1917 г.). Само государство определяется, как tsardom (Nisbet Bain 1915, 46) «царство», слово образованное путем частичного калькирования (русское tsar и исконный английский суффикс -dom). Верхнюю ступень общественной иерархии занимает семья правителя - царя: the Tsar (Nisbet Bain 1915, 22) - «царь», the Tsaritsa (Nisbet Bain 1915, 29) - «царица», слово, потребовавшее особого комментария (the consort of the Tsar (Nisbet Bain 1915, 29) - «супруга царя»), их дети, the Tsarevna 
(Nisbet Bain 1915, 22) - «царевна» и the Tsarevitch (Nisbet Bain,1915, 87) - «царевич». Названия членов царской семьи переданы при помощи транслитерации. В переводе Р.Нисбет Бейна кцарю обращались: Gosudar (Nisbet Bain 1915, 32) - «государь», причем это обращение сопровождалось комментарием: Emperor (Nisbet Bain 1915, 32) - «император». В переводе 2000 г. к царю обращаются по-европейски Your Majesty (Finist 2000, 32) - «Ваше Величество». Царской семье служат boyars (Nisbet Bain 1915, 29) - «бояре», и этому слову дается пояснение: nobles (Nisbet Bain 1915, 29) - «знать». В переводе П.Уилера двор составляют Boyars and Court Ministers (Wheeler 1957, 87) - «бояре и министры двора». Если «бояре» относятся к русским реалиям, тогда как слово “министр» лишено какой-либо особой национальной окраски, но может считаться «европейским». Двору противопоставляется жизнь простых людей со своей иерархией. Жители деревень, мужики (muzhik (Nisbet Bain 1915, 25) - «мужик», или peasant (Nisbet Bain 1915, 25) - «крестьянин») подчиняются сельскому старосте, или «голове» (Golova (Ralston 1873, 42)), а за порядком в крестьянском обществе следит «казак» (Cossack (Ralston 1873, 42)). Все эти слова переданы при помощи транслитерации. В XX в. в сказках появляются слова, напоминающие скорее о западноевропейском обществе: a duke (Yoch Schwab 1934, 15) - «герцог», a princess (Finist 2000, 16) - «принцесса», nannies and governesses (Finist 2000, 16) - «няньки и гувернантки», соответствующие традиционным «нянькам и мамкам».

Против ожидания группа реалий, обозначающих национальные пищу и питье, оказалась очень маленькой: vodka (Nisbet Bain 1915, 51) - «водка», то есть Russian brandy (Nisbet Bain 1915, 51) - «русское бренди». Бренди и водку объединяет только то, что это крепкие алкогольные напитки, но в состав водки входит спирт, который получают из пшеницы, картофеля ит.д., а бренди изготавливается из фруктовой браги или путем дистилляции виноградного вина. Название другого напитка - kvas (Finist 2000, 26; Wheeler 1957, 50) («квас»). Транслитерируются и churochki (Nisbet Bain 1915, 55) [опечатка charochki - M.H.], переводчик прибавляет объяснение: small glass or bowl for drinking spirits (Nisbet Bain 1915, 55) - «маленькие стаканы или чаши для спиртных напитков». С другой стороны, традиционное русское блюдо «щи» переводится описательно - cabbage soup (Wheeler 1957, 56) («капустный суп»). Интересно, что типичные признаки русской повседневной жизни также были переданы при посредстве аналога (вместо «баня» - bathroom (Nisbet Bain 1915, 27), «ванная комната») или описательно (вместо «иконы» - the holy pictures (Ralston 1873, 47), букв. «священные картины»)

Русская природа также описана скудно, но словосочетания описывают самые характерные черты России: the broad steppe (Nisbet Bain 1915, 32) - «широкая степь», 
a dense forest (Nisbet Bain 1915, 32) - «густой лес», в котором водится sable (Nisbet Bain 1915, 41) - «соболь».

Интересны переводы названий сказочных существ и волшебных предметов. Если У.Р.Ральстон, первый переводчик русских сказок, передал слово «леший» при помощи транскрипции - the Leshy (Ralston 1873, 206), то Р.Нисбет Бейн передает название духа - хозяина леса при помощи словосочетания wood demon (Nisbet Bain 1915, 48) - «злой лесной дух», причем национальный колорит утрачивается. Советская переводчица Ирина Железнова использует слово goblin (the wood goblin «лесной гоблин» (Words of Wisdom 2000, 142)), то есть маленькое уродливое существо, напоминающее карлика, которое любит причинять неприятности людям. Изначально гоблин является героем не только английского, но и французского, точнее нормандского, фольклора. Лешего с гоблином объединяет лишь склонность вредить людям, но образ лешего гораздо более сложен: леший может менять свой облик, он может выглядеть карликом или великаном, может принимать облик родных и знакомых встретившегося с ним человека. Он охраняет свои владения, наказывает пришельцев, но может и помочь им. Замена в переводе русского ишире - славянского «лешего» английским «гоблином» не просто приводит к потере национального колорита, но и вводит в сказку персонаж, принадлежащий чужой культуре, искажает смысл сказки.

Уже на примере передачи реалии «леший» можно увидеть, как менялась переводческая политика по отношению кпередаче названий предметов, явлений, процессов, характерных для русской культуры. У.Р.Ральстон, первый переводчик русских сказок на английский язык, старался избегать транслитерации названий реалий, справедливо полагая, видимо, что они будут утяжелять текст, запутывать читателя, но приводит транслитерированные названия в примечаниях и добавляет свой комментарий. Так, переводя сказку «Морозко», Ральстон опускает диалектное название хлеба «челпан», заменяя его словом, знакомым его английским читателям - a loaf - «каравай, буханка хлеба»: he took out a loaf and cut bread for himself and his daughter (Ralston 1873, 216) - «он вынул каравай и отрезал хлеба себе и дочери». Тем не менее, слово «челпан» не исчезает окончательно. У того, кто изучает русский язык или интересуется Россией, есть возможность познакомиться с этим словом в переводческом комментарии: Chelpan, a sort of dough cake, or pie without stuffing (Ralston 1873, 216) - «Челпан, вид круглого хлеба из дрожжевого теста или пирог без начинки». Из комментария Ральстона явствует, что замена «челпана» на «каравай» вполне правомерна даже при адаптации сказки на русском языке, поскольку оба вида хлеба имеют сходные признаки: они делаются из дрожжевого теста и не имеют начинки. И все же Ральстон сохраняет диалектизм, пусть и в постраничной сноске, 
поскольку «челпан» оказывается не совсем обычным хлебом. Это свадебный каравай, а по сюжету сказки деду приходится везти свою дочку к жениху - Морозко. Помещая реалию в постраничную ссылку, переводчик оставляет своему читателю возможность более глубокого прочтения сказки.

По такому же пути Ральстон идет, переводя такие реалии, как «суженыйряженый» и «женихи», причем обнаруживает знание тонкостей русского языка и русской народной культуры. Первая реалия передана в сказке «Морозко» как bridegroom - «жених, новобрачный» (Ralston 1873, 218), то есть определенный молодой человек, уже выбранный в мужья девушке, ее судьба. В постраничном комментарии находим реалию, переданную путем транскрибирования - sushenoiryazhenoi (Ralston 1873, 218). Ральстон не снабжает эту реалию никаким комментарием, поскольку для него важен факт определенности, избрания жениха, а не действия девушки, связанные с понятием «суженый-ряженый» (например, святочные гадания, во время которых определяется, с кем девушке суждено обвенчаться, кто ее «суженый»). Если «суженый-ряженый» может быть только один, то парней, обращающих внимание на девушку, может быть и несколько. Ральстон употребляет в переводе «Морозко» слово suitors (Ralston 1873, 218) - «поклонники», молодые люди, которые могут просить руки девушки, но они все находятся в равном положении. Ральстон приводит и русскую реалию, передавая ее при помощи транслитерации, - zhenikhi (Ralston 1873, 218), то есть молодые люди, выражающие желание жениться и достаточно взрослые для этого. В отличие от «суженого-ряженого» они выражают желание соединить свою судьбу с определенной девушкой, но еще не знают ее решения.

Некоторые реалии не имеют аналога в английской культуре. Таковы лапти, крестьянская обувь жителей Северной и Восточной Европы (финнов, прибалтов, русских, а также восточнославянских народов). Ральстон пользуется описательным переводом: on the log there sat a moujik plaiting a bast shoe (Ralston 1873, 206) - «на бревне сидел мужик и плел башмак из лыка».

Случай слова «богатырь» для переводов Ральстона не совсем обычен: переводчик помещает транслитерированное слово в текст - he himself a bogatir! (Ralston 1873, 216) - «он сам богатырь!», в а в комментарии объясняет: Bogatir is the regular term for a Russian "hero of romance' (Ralston 1873, 216) - «"Богатырь" - это обычный термин для русского "героя [рыцарского] романа"», то есть рыцаря. Можно сказать, что Ральстон подобрал точный аналог для русской реалии, но смог и сохранить национальный колорит. В более поздних переводах «богатырь» прямо заменяется на knight, например: Does what you have done befit an honourable knight? 
(Finist 2000, 14) - «Подобает ли то, что ты сделал, делать благородному рыцарю?» В этом случае национальный колорит в переводе утрачен.

Если У.Р.Ральстон старался как можно точнее передать названия русских реалий на английском языке, то у следующего по времени переводчика, Р.Нисбет Бейна, ошибок гораздо больше. Трудно сказать, вызваны ли эти ошибки незнанием русской народной культуры или незнанием языка. Ярким примером ошибочного перевода стало предложение: The life of man is like a variegated tapestry, interwoven with dark flowers and bright (Nisbet Bain 1915, 43) - «Жизнь человека подобна разноцветному гобелену, затканному темными и яркими цветами». Гобелен, ковер ручной работы, на котором выткана некая композиция или картина, является европейской, точнее изначально французской, реалией. Гобеленами украшали сначала средневековые замки, затем дворцы королей и знати. Конечно, в контексте, где говорится о царской семье, упоминание гобелена, сравнение с ним человеческой жизни, может показаться уместным. Однако, если обратиться к оригиналу, с которого Нисбет Бейн делал перевод, к книге П.Н Полевого «Русские народные сказки», мы увидим совершенно иной образ: «Век человеческий, словно ткань пестрядевая, что цветами черными и красными переткана» (Полевой 1874, 27). Пестрядевая ткань, которую упоминает Полевой, сразу напоминает нам, что перед нами народная сказка, пусть и рассказывается в ней о царе и его семье. Такую ткань из разноцветных льняных или хлопчатобумажных ниток крестьянки ткали дома для нужд семьи. Обычно для основы и утка использовали разные нитки, поэтому белые ицветные нитки переплетались. Из пестрядинной ткани шили повседневную одежду, например, рубахи, фартуки, сарафаны, шаровары. С гобеленом пестрядинную ткань роднит только изготовление вручную, в остальном это совершенно разные ткани, в том числе вызывающие и разные культурные аллюзии. Перевод Нисбет Бейна показывает, что и слово «цветами» вызвало у него трудности, потому что форма множественного числа творительного падежа слов «цвет» и «цветок» совпадает.

Переводы сказочных реалий наводят на мысль, что Нисбет Бейн недостаточно хорошо знал русский язык. Как кажется, он не чувствовал внутренней формы слова и потому делал ошибки в переводах. В одной из сказок в сборнике П.Н.Полевого встречаем «скатертку-хлебосолку» (Полевой 1874, 30). Название скатерти происходит от прилагательного «хлебосольный», то есть гостеприимный, щедро угощающий. Такое название вполне соответствует характеру скатерки, которая готова кормить всех, кто ее расстелет, причем не только хлебом и солью, но и самыми разнообразными кушаньями. Нисбет Бейн переводит «скатерткухлебосолку» буквально, как a little bread-and-salt table-cloth (Nisbet Bain 1915, 49), 
и не учитывает того, что дорогих гостей встречали хлебом-солью, чтобы выразить свою радость от встречи с ними, но на стол ставили все самое лучшее, что было в доме.

Сказочные реалии, смысл которых совершенно искажен, часто встречаются в русских сказках, - это шапка-невидимка и терем, где обычно живет красна девица, если только она не крестьянская дочь. Нисбет Бейн понимает сложное слово «шапка-невидимка» как an invisible little cap (Nisbet Bain 1915, 49) - буквально «невидимая шапочка», а не как "шапка, которая делает невидимым того, кто ее надевает». «Крепкий терем» (Полевой 1874, 30), то есть комнаты на верхнем этаже дворца или отдельно стоящее высокое строение, где живут незамужние дочери хозяина дома, превращаются у Нисбет Бейна в the strong fortress - «мощную крепость» (Nisbet Bain 1915, 30), в укрепленное здание или место, защищающее от нападений врага.

\section{Передача стилистических особенностей русской сказки.}

Говоря о языке и стиле русских народных сказок, нужно помнить, что в течение долгого времени они были устным жанром. Формульные выражения, характерные для них, возникли как средство, помогающее запоминанию текста. Таковы повторы, синонимические сочетания, устойчивые эпитеты. Описания сказочных героев можно назвать каноничными, соответствующими определенным раз и навсегда правилам, поскольку и их действия однотипны. Для сказочных текстов характерны, с одной стороны, архаизмы, историзмы, диалектная лексика, с другой, основной текст сказки близок к разговорной речи. С этими особенностями языка и стиля русских народных сказок столкнулись переводчики.

В передаче особенностей языка и стиля сказок можно отметить две естественные тенденции - сохранение характерных черт русской сказки и, напротив, их сглаживание.

Первый переводчик русских народных сказок, У.Р.Ральстон, предпочитал буквальный перевод, так что даже сохранял порядок слов оригинала, не отвечающий нормам английского языка. Так, в английском переводе he went with his sisters into the garden green to stroll (Ralston 1873, 85) - «он пошел со своими сестрами погулять в зеленый сад" встречаем выражение the garden green, соответствующее сказочной формуле «сад зеленый» даже порядком слов.

Ральстон точно, практически дословно, переводил и русские фразеологизмы, не пытаясь подобрать английские аналоги. Так, в предложении now you will sooner see your own ears than Marya Morevna (Ralston 1873, 88) - «теперь ты скорее увидишь 
свои уши, чем Марью Моревну» можно легко угадать «теперь не видать тебе Марьи Моревны как своих ушей».

Традиция передавать дословно зачины и концовки русских народных сказок, малоизменяемые элементы, также начинается с переводов Ральстона: In a certain kingdom there lived a Prince Ivan (Ralston 1873, 85) - «В некотором царстве жил принц/царевич Иван».

У Ральстона находим и попытку архаизации речи персонажей: Art thou warm, maiden? (Ralston 1873, 217) - «Тепло ли тебе, девица?» Видимо, это была попытка придать речи героев народную окраску.

Если текст сказок, записанных А.Н.Афанасьевым, с точки зрения языка приближается к нейтральному, то сказки, обработанные П.Н.Полевым, гораздо более богаты стилистическими средствами. Переводчик сборника Полевого Р.Нисбет Бейн также выбрал буквальный или по возможности близкий ктексту способ перевода.

Одной из черт русской народной сказки является употребление словосочетаний, в состав которых входят числа. В сказках, обработанных Полевым, таких словосочетаний много, и переводчик точно передает их: seven-and-seventy of your nurses and seven-and-seventy of your guardians (Nisbet Bain 1915, 43) «семьдесят семь нянек и семьдесят семь воспитателей»; twelve youths and twelve maids (Nisbet Bain 1915, 49) - «двенадцать юношей и двенадцать девушек»; three hundred and three buckets of mead to toast him (Nisbet Bain 1915, 41) - «триста три ведра меда, чтобы выпить за его здоровье»; bade them regale his whole realm with beer for three days (Nisbet Bain 1915, 41) - «попросил их потчевать все его царство пивом в течение трех дней».

В текстах сказок, обработанных Полевым, достаточно много синонимических сочетаний, которые также переданы Нисбет Бейном, например, Tsar-Gosudar (Nisbet Bain 1915, 46) - «Царь-государь»; the old man began to lament and weep... (Nisbet Bain $1915,17)$ - «старик начал стенать и плакать», she began to howl and cry... (Nisbet Bain 1915, 15) - «она начала выть и плакать»; to find him hale and whole (Nisbet Bain 1915, 35) - «найти его живым и здоровым».

У Нисбет Бейна встречаем дословные переводы фразеологизмов, играющих роль формул в сказках: as goodly as blood and milk. (Nisbet Bain 1915, 58) - «красивый, как кровь с молоком»; a ruddy countenance like milk and blood (Nisbet Bain 1915, 12) «румяный, как кровь с молоком»; was walking like a peacock (Nisbet Bain 1915, 58) «шла, как пава»; turned as scarlet as the red poppy-flower (Nisbet Bain 1915, 59) «покраснела, как маков цвет». Как и Рольстон, Нисбет Бейн иногда переводит 
сказочные формулы слово в слово: the lovely maiden soul (Nisbet Bain 1915, 120) «прекрасная девица-душа»; good youths (Nisbet Bain 1915, 31) - «добры молодцы».

Стремление Нисбет Бейна передать своеобразие языка сказок, собранных Полевым, приводит и к тому, что некоторые формулы он передает пусть и точно, но многословно. В переводном предложении the daughter was beautiful with a beauty that no man can imagine or devise and no tale can tell (Nisbet Bain 1915, 12) - «дочь была красива такой красотой, что никто не может вообразить или выдумать, ни одна сказка не расскажет» - можно увидеть аналог «ни в сказке сказать, ни пером описать». Выражение at the merry banquet and the wedding feast - «на веселом пиру и на свадебном празднестве» (Nisbet Bain 1915, 59) явно соответствует известной сказочной формуле «честным пирком да за свадебку». Обычное выражение русских сказок "долго ли, коротко ли...» стало унисбет Бейна довольно пространным предложением: a long time and a little time passed by... (Nisbet Bain 1915, 14) "долгое время и короткое время прошли...» Часто по сюжету сказки герой в детстве растет очень быстро, что описывается выражением «не по дням, а по часам». У Нисбет Бейна находим буквальный перевод: He grew not by the day but by the hour... (Nisbet Bain 1915, 44).

Еще одним ярким примером является передача варианта столь же распространенного предложения-связки «Скоро сказка сказывается, да не скоро дело делается»: The tale of his going is soon told, but the deed that he did is not soon done (Nisbet Bain 1915, 47) - «Сказка о его путешествии быстро рассказана, но дело, которое он сделал, не скоро сделано».

Интересен перевод пословицы «суженого и на коне не объедешь». Нисбет Бейн постарался как можно передать ее смысл: ... a destined wooer cannot be avoided even on a swift horse (Nisbet Bain 1915, 42) - «поклонника, предназначенного судьбой, не избегнуть и на быстром коне».

Как уже было сказано, зачины и концовки русских народных сказок тоже формульны. В сказках, изданных Полевым, находим: «В некотором царстве, в некотором государстве жил-был царь» (Полевой 1874, 13). Нисбет Бейн передает этот зачин таким образом: In a certain kingdom, in a certain empire, there once lived a Tsar (Nisbet Bain 1915, 30) - «В неком королевстве, в некой империи жил однажды царь». Как видим, переводчик выбрал слова kingdom - «королевство» (первое значение слова) и етріге - «империя» (первое значение слова), поскольку они понятны английским читателям. Рядом с такими словами легко догадаться о значении незнакомой реалии Tsar - «царь» - ипонять ее как «правитель». Традиция перевода зачинов иконцовок как можно ближе коригиналу для сохранения национального колорита сохранялась до конца 50-ых гг. XX в. Так, 
у П. Уилера находим: In a certain Tsardom, across three times nine kingdoms, beyond high mountain chains, once lived a merchant (Wheeler 1957, 49) - «В некотором царстве, за три-девятью королевствами, за высокими горами жил-был купец». Следует отметить, что более поздние переводчики отказались от подобного близкого к тексту перевода и стали использовать аналог из английских народных сказок once upon a time there lived..., который может переводиться как «однажды, некогда, во время оно, когда-то жил-был...», например, Once upon a time there lived a peasant (Finist 1979, 3) - «Во время оно жил-был крестьянин»; Once there lived an old man and his wife (Russian Folk Tales 1987, 135) - «Давным давно жили-были старик со своей женой»; Once upon a time there lived an old man who had three sons (Russian Folk Tales 1987, 93) - «Жил некогда старик, у которого было три сына».

Если рассмотреть концовки сказок, то можно проследить ту же тенденцию. Первые переводчики стараются переводить концовки близко ктексту. Переводы Нисбет Бейна предоставляют нам много примеров точных переводов. Так, например, концовка сказки «Пойди туда - не знаю куда, принеси то - не знаю что» в сборнике Полевого такова: «Он на то свое согласье дал и весь свой век тем царством управлял» (Полевой 1874, 284). Нисбет Бейн переводит концовку практически слово в слово: To this he gave his consent, and ruled that kingdom peaceably all the days of his life (Nisbet Bain 1915, 87) - «На это он дал свое согласие и мирно правил этим королевством во все дни своей жизни». Обратный перевод на русский язык показывает, что в этом случае добавление незначительно (peaceably «мирно», но и «спокойно»), а выражение "свой век», в переносном смысле означающее «жизненный путь человека», переводчик заменил выражением пусть и более громоздким, однако лишенным всякой метафоричности (all the days of his life - «во все дни своей жизни»). П. Уилер также стремился сохранять формульность концовок. Так в сказке о морском царе, название которой переведено как TsarMorskoi The Sea-Ruler, П.Уилер передает заключительные слова сказки так: There they two dwelt together in happiness to the end of their lives, and in time he ruled the Tsardom in his father's stead (Wheeler 1957, 49) - «Они жили там вместе в радости до конца своей жизни, и со временем он [царевич] стал править царством вместо своего отца». А вот как переведена концовка «Сказки об Иване-царевиче, жар-птице и о сером волке» из собрания А.Н.Афанасьева: “...Иван-царевич женился на прекрасной королевне Елене и начал с нею жить дружно, полюбовно, так что один без другого ниже единой минуты пробыть не могли» (Афанасьев 1984, онлайн). В конце XX в. российский переводчик А.А.Замчук продолжает эту же традицию, переводя концовку близко к тексту: Tsarevich Ivan married Princess Elena the Beautiful and they lived in true love and friendship and no one of them could spend a single minute 
without the other's presence (Zamchuk 1998, 22) - «Царевич Иван женился на принцессе Елене Прекрасной, и они жили в истинной любви и дружбе, и ни один из них не мог провести и одной минуты в отсутствие другого». Изменения, которые внес А.Замчук, незначительны и направлены на то, чтобы англоязычный читатель легче воспринимал инокультурный текст. Так, в русско-английских словарях «королевна» обычно переводится как king's daughter - «дочь короля» илишь изредка как princess - «принцесса», вариант, который и выбрал переводчик, ориентируясь на англоязычную культуру.

Как переводчики-иностранцы работали с языком русских сказок, можно понять из книги, изданной в Лондоне в 1919 г. А.Брылинской и Г Смитом. В издании Russian Fairy Tales. An Accented Russian Reader with Notes and Vocabulary - «Русские сказки. Русская хрестоматия для чтения с проставленными ударениями, примечаниями исловарем» (Brylinska, Smith 1919) весьма ценны именно комментарии, позволяющие понять, как могло происходить переосмысление национально окрашенной русской лексики англоязычными переводчиками. Так, например, фразеологизм «хоть глаз выколи» сначала переводился буквально с пометой lit. - even pick out an eye (pick out - букв. «выковырять, вытащить»). Это метафорическое выражение, звучащее несколько кровожадно, тут же объясняется: even if one's eyes were picked out it would make no difference - «даже если бы у кого-то были выколоты глаза, разницы бы не было». Последняя часть комментария отсылает читателя к народной культуре: A popular expression to indicate pitch darkness - «Народное выражение для обозначения кромешной тьмы» (Brylinska, Smith 1919, 3). Таким же образом объясняется выражение «ни свет, ни заря»: сначала даются буквальный английский перевод neither light nor dawn - «ни свет, ни заря»; затем английский аналог before daybreak - «до рассвета», наконец, объяснение выражения - very early, «очень рано» (Brylinska, Smith 1919, 28). В примечаниях к текстам сказок даются объяснения и некоторым реалиям народной жизни, например, «суженыйряженый». Буквальный перевод fated and appointed (Brylinska, Smith 1919, 29) «предопределенный и назначенный» - сопровождается культурологическим комментарием: Epithet applied to a bridegroom, as in olden times he was chosen by parents without their daughters' knowledge or consent (Brylinska, Smith 1919, 29) «эпитет, относящийся кжениху, поскольку встарые времена его выбирали родители, не сообщая об этом дочери и не спрашивая ее согласия». Авторы хрестоматии переводили и комментировали и устойчивые выражения, типичные для жанра сказки. Так, например, концовка «на душе пьяно и сыто стало» переводится как I was completely satisfied with food and drink (Brylinska, Smith, 1919, 42), то есть «я был полностью удовлетворен едой и питьем». Концовка «по устам 
текло, а в рот не попало» снабжена не только переводом It trickled through my moustache, but fell not into my mouth (Brylinska, Smith 1919, 30) - «[Питье] просочилось сквозь мои усы, но не попало в рот», но и развитым комментарием. С одной стороны, читатель узнает об особенностях использования выражения в русском фольклоре: A regular formula in the description of a wedding feast in Russian fairy tales (Brylinska, Smith 1919, 30) - «Обычная формула для описания свадебного пира в русских сказках». С другой, точно определяется, как нужно понимать эту «формулу»: This jocular conclusion suggests that the story teller treats himself and his narrative lightly (Brylinska, Smith 1919, 30) - «Это шутливое заключение намекает на то, что рассказчик воспринимает и себя, и свой рассказ несерьезно», то есть в юмористическом ключе. Комментарии к хрестоматии Брылинской и Смита давали возможность будущим переводчикам отступить от уже сложившейся традиции перевода русских сказок, научиться подыскивать аналоги национально окрашенной лексике и русским реалиям.

Одной из характерных черт английских переводов русских сказок является употребление архаизмов, особенно в речи сказочных персонажей. Вплоть до конца 50-ых гг. XX в. встречаем в переводах устаревшие грамматические формы, например, у Ральстона: Qua, qua! Ivan the Tsarevich! wherefore art thou so sad? <...> Or hast thou heard unpleasant words from thy father the Tsar? (Ralston 1873, 119) - «Ква, ква, Иван царевич! Почему ты так печален? <...> Или ты услышал неприятные слова от твоего отца, царя?» (архаичные формы art - совр.are; thou - coвр.you, hast совр.have, thy - совр. уоur), у Нисбет Бейна: How's this, darling little Princess, thou art for ever fretting? (Nisbet Bain 1915, 155) - «Как же так, дорогая царевна, ты всегда недовольна» (архаичные формы art - совр.are; thou - совр.уоu), What dost thou say now... (Nisbet Bain 1915, 156) - «Что ты скажешь теперь...?» (архаичные формы dost совр.do; thou - совр.уои); у Уилера Wert thou not frightened? (Wheeler 1957, 90) - «Hе испугалась ли ты?» (архаичные формы wert - совр.were; thou - совр.уои). Позже архаизмы постепенно исчезают из переводов, язык персонажей с точки зрения грамматики становится все более простым, например: Your Majesty. There is a kid in your garden and a maiden who is so nice leads him on a belt (Zamchuk 1998, 4) - «Ваше Величество, в Вашем саду - козленок, и девица, которая так мила, ведет его на ремешке». Единственное архаичное слово здесь maiden - «девица». 


\section{Проблема ошибок и потерь при переводе русской сказки.}

Разговор о бытовании русских сказок на английском языке не будет полон без указания на потери при их переводе. Некоторые потери и искажения смысла происходят, как кажется, от недостаточного знания переводчиками русского языка. Много подобных примеров можно найти в переводах Р.Нисбет Бейна. В сказке «Морозко» встречается выражение «как сыр в масле купалась» (Полевой 1874, 298), которое Нисбет Бейн перевел как would have swum in cheese and butter (Nisbet Bain $1915,17)$ - «плавала бы в сыре и масле». В этом выражении «сыр» употребляется в значении "творог», получающийся путем сквашивания молока. На начальном этапе сквашивания молока получается простокваша, довольно густое закисшее молоко. Теоретически в нем можно «плавать». Однако в английском языке cheese понимается в первую очередь как твердый продукт, хотя в Европе вообще и в Англии в частности известны многие разновидности сыров. Наиболее известные английские сыры, например, чеддер и стилтон, относятся к твердым сырам, в них «плавать» невозможно. Таким образом, для англоязычного читателя фраза would have swum in cheese and butter (Nisbet Bain 1915, 17) становится совершенно непонятной.

Иногда причина искажения текста в переводе не вполне ясна. Так, например, предложение «Чудное дело случилось: вышли царевны в царский сад погулять, пестрых бабочек половить, красного маку пощипать и наливными яблочками полакомиться» (Полевой 1874, 26-27) в переводе Нисбет Бейна по непонятной причине теряет словосочетание «пестрых бабочек половить»: A strange thing had happened. The Tsarevnas had gone out to walk in the Tsar's garden to pluck a few sweet peas and pull off a red poppy or two and feast upon a few ripe pippins (Nisbet Bain 1915, 43) - «Случилась странная вещь. Царевны вышли погулять в царский сад, чтобы сорвать немного цветного горошку, выдернуть один-два алых мака и насладиться несколькими спелыми яблоками-пепинками». Интересно, что для передачи словосочетания «наливное яблочко», то есть яблоко особого, летнего, сорта, полупрозрачное, налитое соком, Нисбет Бейн использует название старинного сорта «пепинка», распространенного в России; его плоды отличаются сочностью. Введение «цветного», или букв. “сладкого», горошка, который в этом контексте может означать и цветок в пару к «алому маку», и лакомство, подобное «спелым яблокам-пепинкам», делает текст более уравновешенным и единообразным, но образы царевен становятся скучными и плоскими: это не веселые резвые девушки, бегающие за бабочками, собирающие цветы и угощающие друг друга яблоками, а степенные и хозяйственные молодые дамы, более интересующиеся едой, чем 
весельем. Можно предположить, что образ юных царевен, созданный в оригинале русской сказки, с точки зрения переводчика не соответствовал их грядущей судьбе: они, девушки на выданье, будут украдены из царского сада, и в следующий раз мы встречаем их уже замужними женщинами.

В переводе иногда происходит сдвиг значения, который обнаруживается только при его сравнении с оригиналом. Так, например, Полевой пишет: «Хороша песня, да ведь казны царской ею не наполнишь, царства не защитишь, излого ворога не побьешь...» (Полевой 1874, 28). Читателю, выросшему в русской языковой среде, понятно, что сравнения, которые находим в сказке, имеют переносный смысл, они родственны по значению таким известным русским пословицам, как "соловья баснями не кормят», означающая, что от слов нужно переходить к делу или что нужно оказать кому-то не только словесную, но и материальную поддержку, или «из спасибо шубу не сошьешь», то есть за похвалой должно следовать и материальное вознаграждение. Смысл предложения из оригинального текста состоит в том, что песни могут доставлять удовольствие, но не приносят ощутимой пользы в реальной жизни. Нисбет Бейн меняет время глаголов, переводя действие из настоящего в прошедшее: Beautiful songs they were, but they did not replenish the Tsar's treasure. nor defend the realm, nor smite the evil foe (Nisbet Bain 1915, 44) «Красивые это были песни, но они не восполнили царского сокровища, не защитили государства, не разбили злого врага». Если бы Нисбет Бейн ввел в свой перевод прошедшее время модального глагола can - «мочь, быть в состоянии», изначальный смысл был бы сохранен. Однако он не сделал этого, и перед читателем появляется герой, который производит бессмысленные действия - пытается песнями увеличить количество царского золота, защитить границы государства и победить врагов.

Вот еще один похожий пример сдвига значения: «...тогда увидишь ты, что умразум острее меча булатного и крепче копья закаленного» (Полевой 1874, 29). Слова героя можно понять как пословицу или афоризм, заключающие в себе глубокий смысл, философское обобщение. Переводчик ввел в свой текст личное местоимение my - «мой», и образ героя, Ивана царевича, оказался искаженным: then thou shalt see that my wisdom and my wit is sharper than a damask blade, and stronger than a lance of steel (Nisbet Bain 1915, 46) - «тогда ты увидишь, что моя мудрость и мой ум острее дамасского клинка и крепче стального копья». Вглазах читателя герой оказывается скорее самоуверенным хвастуном, чем мудрецом, постигшим некие духовные истины.

Переводчику приходится прибегать кдобавлениям иуточнениям, чтобы донести до читателя точный смысл текста. Вот Иван царевич говорит отцу, не верящему, что сын способен выполнить поручение: «...если кто тебе такую службу 
сослужит, отдай тому царство мое, а мне вели у него поваренком быть, скоморохом слыть» (Полевой 1874, 29). Нисбет Бейн передает это предложение так: if any one of them shall do thee this service, give to him my tsardom and bid me be unto him as a scullion, to lick his pots, and as a fool to make him sport (Nisbet Bain 1915, 46) - «если кто-то из них сослужит тебе эту службу, отдай ему мое царство и вели мне быть при нем поваренком, чтобы вылизывать его горшки, и шутом, чтобы ему было над кем посмеяться». Такая реалия как scullion - «поваренок», то есть «помощник повара» или «слуга, выполняющий физическую работу на кухне», была понятна англоязычному читателю, но, видимо, было неясно, почему быть поваренком унизительно, поэтому Нисбет Бейн добавляет деталь to lick his pots - «вылизывать его горшки», питаться объедками. С другой стороны, русская реалия “скоморох» «средневековый актер и музыкант» - лишь частично совпадает по значению со словом fool - «шут», живший при дворе вельможи или короля и веселивший своего хозяина шутками, забавными историями, глупыми выходками. Тем не менее, скоморохи тоже разыгрывали забавные сценки, вызывавшие смех, поэтому замена русского «скомороха» на нейтрального, понятного европейцам «шута» вполне оправдана. Потеря в этом случае заключается в невозможности передать ритм и рифму: отрывок «поваренком быть, скоморохом слыть» представляет собой двустопный каталектический хорей, причем рифмуются исуществительные «поваренком» - «скоморохом», и глаголы «быть» - «слыть».

Подобного рода потери довольно часты у Нисбет Бейна, например, перевод концовки «Сказки об Иване-Царевиче и гуслях-самогудах»: «..жил он долго, царствовал славно, угощал меня исправно, то-то я исказку про него сложил забавно» (Полевой 1874, 39). Все наречия в этом отрывке рифмуются, напоминая русский народный стих, называемый раешным. Такие стихи сопровождали балаганные представления на ярмарках в дореволюционной России. Ни ритм, ни рифму передать переводчику не удалось: And he lived long and regned gloriously, and feasted me right royally, so I made up this merry tale about him (Nisbet Bain 1915, 60) «И он жил долго, и правил славно, и угощал меня и вправду по-царски, поэтому я сложил о нем эту веселую сказку».

В переводе иногда теряются и сочетания синонимов, например, в случае «благослови меня в путь-дорогу!» (Полевой 1874, 29) словосочетание двух синонимов «в путь-дорогу» заменяется словосочетанием, соединяющим в себе смысл обоих существительных: on my journey (Nisbet Bain 1915, 47) - «на мое путешествие». Эти же два синонима, входящие в словосочетание «идти путемдорогою», также переводятся одним словом: «Шел, шел Иван-царевич путем- 
дорогою...» (Полевой 1874, 31) - Ivan the Tsarevich went on his way (Nisbet Bain 1915, 50), то есть «Иван-царевич шел по своей [то есть ранее выбранной] дороге».

\section{Переводы русских сказок как часть англоязычной культуры.}

Благодаря трудам переводчиков - и тех, кто был упомянут в этой главе, и тех, чьи работы не попали в поле зрения автора - русская сказка постепенно становится частью англоязычной культуры, однако, как кажется, разница между самими культурами, русской и западной, в частности культурой Британии и США, достаточно велика, и поэтому в рецензиях на сборники русских сказок в первую очередь подчеркивается сходство между непривычными русскими сказками и сказками, известными читателю с детства: «Некоторые русские сказки имеют сходство с народными сказками Западной Европы, а другие знакомят нас с необыкновенными существами и ситуациями, присущими только русскому воображению» (3), «В сокровищнице русских сказок есть герои, в некоторых отношениях сходные с нашими любимыми героями, авдругих отношениях совершенно на них не похожие» (5), «В русских сказках есть излые ведьмы, и прекрасные принцы, но также и дома, которые разгуливают на куриных ногах, и волшебные говорящие рыбы» (5). Неизвестное легче объяснить через известное, проводя параллели между русскими и западными сказками, причем читателю указывают и на сходство, и на различие: «"Царевич" - это прекрасный принц, а Дед Мороз русского фольклора, с одной стороны, похож на Рождественского Деда, с другой, на сказочное существо Джека Мороза. Вместо нашей злой колдуньи во многих русских сказках говорится о Бабе Яге, старой ведьме, которая летает в ступе, подгоняя ее пестом, и живет в доме, разгуливающем по округе на куриных ногах» (5).

Разница культур заметна даже маленьким читателям. Так, читательница, которой в шесть лет подарили русские сказки, вспоминает: «Волшебные сказки, к которым я привыкла, например, «Спящая красавица» и «Золушка», изображали беспомощных девиц и доблестных принцев, а герои русских сказок были другие. Большинство девочек были очень умными, добродетельными и изобретательными; большинство мальчиков были настоящими лентяями, неумелыми и неудачливыми» (4). Интересны наблюдения над языком русских сказок в сравнении с английскими: «Английские сказки, которые мы узнаем в детской, начинаются словами: «Давнымдавно...». Русские сказки чаще всего начинаются словами: «Жили-были...». Эта фраза наводит на мысль: «Все еще живут и все еще существуют...» - так фантазия и реальность сосуществуют в литературе и жизни» (4). 
Процесс включения русских сказок ванглоязычную культуру, их культурная адаптация, непрост. Слишком многое приходится объяснять читателям - и большим, и маленьким, для чего издания сказок сопровождаются комментариями, даже визуальными. Выпуская в свет книгу «Баба Яга: Вредная Ведьма Востока в русских сказках» (8), издатели вынуждены были уделить особое внимание оформлению, чтобы читатель мог представить себе эту колоритную героиню русского фольклора: «издатели украсили страницы изображениями Бабы Яги, взятыми из фильмов, театральных постановок, репродукциями картин, иллюстрациями и даже рисунками обуви» (8). Само название книги свидетельствует о том, что читательской аудитории требуется объяснить, кто такая Баба Яга. Для этого проводится параллель со сказочной повестью, которую знает каждый американский ребенок, - с книгой Л.Ф.Баума «Волшебник из страны Оз» (8).

На что в первую очередь обращают внимание читатели? Безусловно, на «чисто русских героев» (7): «Среди фантастических героев молодые читатели встретят в этих сказках легендарную Жар-Птицу, играющего на цимбалах Садко, чья музыка могла заставить танцевать Морского царя; ведьму Бабу Ягу с железными зубами, имногих других» (3), «Кощей Бессмертный, Баба Яга, Дева-Лебедь и знаменитая Жар-Птица» (7), «волшебные животные, отважные молодые люди, страшные великаны, злобные ведьмы ипривлекательные морские существа» (6), «живые, захватывающие, поэтические сказки о богах и духах, героях и ведьмах» (1). Особенно воображение маленьких детей, любящих страшные истории, поражает «избушка на курьих ножках, окруженная частоколом из человеческих костей, над которыми возвышаются черепа с горящими глазами» (4).

Одной из сказок, ставших известными в англоязычной читательской среде, оказывается «Василиса Прекрасная», сказка, сохранившая в себе черты глубокой древности. Она делается более понятной маленьким читателям в сравнении с «Золушкой», сказкой Шарля Перро, давно вошедшей в круг детского чтения в адаптированном виде: «самой выдающейся личностью в этих сказках является героиня, чье имя стало названием сказки, Василиса Прекрасная. Как и Золушка, она жила с жестокой мачехой и злобными сводными сестрами, в отличие от Золушки у нее не было никакой феи-крестной, которая могла бы помочь ей, но только волшебная куколка, подарок ее матери, когда та лежала на одре смерти. Куколка помогает Василисе одолеть страшную Бабу Ягу» (4).

Баба Яга, наряду с Василисой, оказывается одной из запоминающихся героинь русского фольклора, пробуждающих интерес кнему: «Впервые я встретилась с Бабой Ягой, когда мне было примерно шесть лет. Я взялась за книжку сказок, иллюстрированную британским художником, поляком по происхождению, 
Яном Пеньковским. ... нарисованный им затейливый силуэт Бабы Яги, летящей по небу в ступе с пестом, или забор вокруг ее избушки, сделанный из человеческих костей, пробудили во мне любовь к сказкам» (5).

Образы Бабы Яги и Василисы используются ивкнигах современных писательниц, работающих в жанре фэнтези. Так, в книге Сары Портер «Васса в ночи» (Sarah Porter, Vassa in the Night) героини живут не в русской деревне на краю дремучего леса, а в Нью-Йорке, где, тем не менее, также происходит множество волшебных событий. Общая сюжетная канва сохраняется: главная героиня книги, Васса (возможно, сокращение от «Василиса»), живет по соседству со свирепой Бабс Ягг, хозяйкой винного погребка, имя которой отсылает нас к русской Бабе Яге. Когда сводная сестра Вассы посылает ее с поручением к Бабс Ягг, Вассе помогает Эрг, заколдованная куколка с дурным характером, которая твердо настроена спасти свою хозяйку (2). С Бабой Ягой встречаются и героини книги Теодоры Госс «Красна, как кровь, и бела, как кость» (Theodora Goss, Red as Blood and White as Bone), дочь дровосека, живущая в дремучем лесу, и переодетая принцесса, обращающаяся к ней за помощью (2). Кэтрин М. Валенте в романе «Бессмертный» помещает героев русского фольклора в необычную ситуацию - во времена и обстоятельства революции 1917 г. (Catherynne M.Valente, Deathless). На первый план в ее книге выходит еще один известный герой русских сказок - Кощей Бессмертный, хотя и Баба Яга в книге упоминается. По сюжету, девушка Мария, потеряв свою некогда счастливую и процветающую семью во время революции, скрывается от страшной действительности в мире колдовства, когда выходит замуж за Кощея Бессмертного. Вразрез с русской фольклорной традицией этот брак оказывается счастливым, но мир вокруг Марии изменяется: «Баба Яга превращается в товарища Ягу, волшебные существа учатся жить при сталинском режиме, а домовые создают комитеты, чтобы перевести свое волшебство на бюрократические рельсы» (2). Книга детской писательницы Кэтрин Ранделл (Katherine Rundell) «В глуши с волками» (The Wolf Wilder) навеяна совершенно определенной русской сказкой: “ ... моя последняя детская книга в некотором смысле является волшебной сказкой: в ней двое детей путешествуют верхом на волках по заснеженной России ... Текстом-источником для меня стала знаменитая русская сказка, “Сказка об Иване Царевиче, Жар-Птице и Сером Волке" » (10).

Для вхождения русских сказок в англоязычную культуру много делают издатели илитературные критики. Врецензиях, публикующихся ив прессе, и в интернете русские сказки активно рекомендуются читателям. Иногда рецензия сообщает о книге самую необходимую информацию идает ей краткую, но благожелательную оценку, как, например, рецензия на переиздание книги сказок 
У.Ш-Р. Ральстона: «Этот текст откроет нечто и читателю-интеллектуалу, и тем, кому просто доставляет удовольствие хорошая сказка» (9), или на книгу сказок Old Peter's Russian Tales (1916), собранную Артуром Рэнсомом: «Наслаждение для читателей любого возраста, любящих сказки» (6). Отрывки, характеризующие книгу сказок Александра Афанасьева, которые можно прочесть на сайте книжного интернетмагазина «Амазон», взяты, видимо, из обширных рецензий, две из которых написаны известными американскими писателями: «К счастью, эти драгоценности были собраны до того, как они были утрачены, и изданы в одном томе, прежде чем они ушли в небытие... Книга полна действия, волшебства и человечности» (газета «Сент-Луис Глоуб-Демократ», St. Louis Globe-Democrat) (7); «Прекрасная книга. Я рекомендую ее читателям любого возраста, интересующимся народной сказкой и ее особыми чертами» (американский писатель Айзек Башевис Сингер, Isaac Bashevis Singer) (7); «Неукротимые, полнокровные и страстные, эти сказки полны действий, которые совершаются по волшебству и по человеческой воле. Они великолепны» (американская писательница Юдора Уэлти, Eudora Welty) (7); «В России устная народная традиция и вправду была волшебным родником, вода которого лилась без устали, оживляя, утешая и просвещая всех, кто черпал из него ... Этим сказкам присущи оригинальность и изобретательность, указывающие на их русское происхождение» (газета «Тайм», Time) (7).

\section{Заключение.}

Как видно из вышеизложенного, перевод русских сказок открывает возможности для их культурной адаптации в англоязычной среде. При этом русская народная сказка может быть достаточно привлекательным материалом для работы, если учитывать ее особенности. Необходимо помнить, что в течение многих столетий русская сказка передавалась от поколения к поколению в устной форме, поэтому она существует, как правило, в нескольких вариантах. Переводчику приходится решать, какой вариант он выбирает. При этом в сказке есть неизменяемые или малоизменяемые элементы, ккоторым относятся название сказки, имена персонажей, формулы и устойчивые выражения. Перед переводчиком русских сказок открываются две возможности. Если он хочет сохранить национальный колорит, при передаче русских реалий ему придется прибегать ктранскрипции и транслитерации, возможно, к калькированию, переводить формулы и устойчивые выражения близко к тексту. Такой подход традиционен, однако недостатком его является перегруженность переводного текста непонятными читателю словами и непривычными синтаксическими конструкциями. Вэтом случае необходим 
переводческий комментарий в виде вставки в текст или постраничного примечания. Если переводчик решает пожертвовать национальным колоритом, он может пользоваться переводом по аналогии, различными заменами, обращаться к целостному преобразованию отдельных фрагментов текста. Такой перевод будет гораздо более ясен для читателя, но, с одной стороны, при таких кардинальных изменениях смысл оригинала может исказиться, с другой, сказка может потерять связь с культурой, ее породившей. Хотя в наши дни преобладает второй подход, как кажется, нельзя окончательно отказаться и от первого. Плоды трудов поколений переводчиков начинают сказываться во вхождении, пусть и небыстром, русских сказок в англоязычную культуру. Важным показателем этого становятся книги англоязычных писателей, источниками для которых послужили переводы русских народных сказок.

\section{Западноевропейская народная сказка в России: издание, бытование, восприятие (чешские, польские, итальянские, английские сказки)}

(Мария Ненарокова)

\section{Российские писатели о сказке.}

Одним из любимых жанров детской литературы в России всегда была сказка. С самого раннего детства сказка сопровождает детей, рассказывая им, по словам замечательного поэта С.Я.Маршака (1887-1964), «обо всем на свете - о краях и народах, о морях и звездах, о том, что близко, и о том, что за тридевять земель, о временах нынешних и давно минувших» (Маршак 1964, 24). Сказка зачастую оказывается первым текстом, который ребенок запомнил на всю жизнь. Так, по выражению российского педагога к.XIX в. Ир.Скворцова, сказки ребенок усваивает «вместе с молоком матери, с ее горячими ласками и нежными словами» (Скворцов-1 1898, 192). В центре любой сказки чаще всего мы видим конфликт добра и «темных сил жизни» (Чуковский 1946, 23). Отождествляя себя с главным героем сказки, стремящимся к победе добра над злом, ребенок «ощущает себя активным участником этой борьбы» (Чуковский 1946, 23). По словам Корнея Чуковского (1882-1969), пожалуй, наиболее читаемого детского поэта России, «сказка является одним из самых действенных средств обогащения и гуманизации детской психики» (Чуковский 1946, 23). В этом заключается привлекательность сказки для воспитания «несметного числа поколений» (Чуковский 1946, 23). Маленькие читатели знакомились не только со сказками своей родины. История издания западноевропейской сказки в России, в частности, чешской, польской, 
итальянской английской, делится на два периода. Один из них охватывает время со 2-ой пол.XIX в. до революции 1917 г, второй начинается в 40-ыХ гг.XX в. и продолжается до сего дня. Подробно об истории переводов, бытования и восприятия сказок Чехии, Польши, Италии, Англии в России будет сказано ниже.

\section{А.М.Горький и издание народных сказок.}

До революции 1917 г. сказки разных народов выходили в разных издательствах и в таких крупных и известных, как, например, товарищество И.Д.Сытина ${ }^{4}$ в Москве, и в небольших издательствах, подобных товариществу скоропечатания А.А.Левенсон. Часто на книге указывается имя «книгопродавца», то есть человека, который владел книжным магазином и торговал книгами, но одновременно мог заказывать типографиям издание книг, которые соответствовали его торговой политике. На сборниках сказок находим такие указания: «Издание книгопродавца А.Д.Сазонова» (Москва), “Издание книжного магазина В.В. Думнова» (Москва). Издавал зарубежные сказки и В.М.Саблин. ВСанкт-Петербурге было известно издательство «книгопродавца В.И.Губинского», издавшего сборники итальянских, английских, польских сказок. Переводы сказок этого времени можно назвать скорее переложениями, пересказами. Часто в тексты переводов вводились русские реалии, герои получали русские имена.

В Советской России уистоков издания произведений для детского и юношеского чтения, в том числе и сказок разных народов стоял Максим Горький (1868-1936), один из самых известных во всем мире русских писателей, «друг детей и детской литературы» (Книга - друг ребенка 1964, с.3).

Интерес Горького к сказкам разных народов отразился уже в его письмах к сыну (1909 г.). Так, однажды он просит сына: «...напиши мне, читал ли “Японские сказки", - если нет, я тебе вышлю их, а также вышлю и сказки североамериканских индейцев» (Горький 1989, 45). Спустя некоторое время в другом письме Горького к сыну находим: «Посылаю тебе, милый сынище, десять японских сказок и «Семилетку». Индейские сказки - те самые, про которые я писал» (Горький 1989, 45).

Вскоре после Октябрьской революции, в 1918 г., Горький возглавил работу по изданию книг для детей (Медведева-1, 10). Полагая, что издательства «Русская литература» и «Всемирная литература», организованные в 1919 г., не смогут сосредоточиться на выпуске детских книг, Горький планировал выпускать их

\footnotetext{
${ }^{4}$ Сведения об издательствах приводятся по каталогам Российской Государственной Библиотеки (Москва) и Российской Национальной Библиотеки (Санкт-Петербург).
} 
в издательстве «Парус», которое он организовал еще до революции (Медведева-1, 10). В том же 1919 г. было создано «Издательство З.И.Гржебина», фактически возглавляемое Горьким. Предполагалось, что с «Издательством З.И.Гржебина» будет сотрудничать академик Сергей Федорович Ольденбург (1863-1934), известный ученый-востоковед. Под его редакцией должны были выходить сказки разных народов. В планах издательства было записано:

Задача этой серии - ввести в детское чтение новые сказки, обогатить сказочное достояние детей, которое уже довольно давно остается одним и тем же. Из богатой сокровищницы народных сказок выбраны те, которые по темам и по интересам являются подходящими кдетскому возрасту; подход к сказкам этой серии не этнографический, а имеет в виду читателя - ребенка, которому желательно показать все многообразие сказки и разное отношение к ней у разных «народов». (Горький 1989, 80).

Однако планам А.М.Горького не было суждено осуществиться при его жизни. После Октябрьской революции 1917 г., когда квласти пришли большевики, народной сказке пришлось нелегко. Советские педагоги 20-ых гг. XX в. считали народные сказки ненужными и даже вредными для воспитания советских детей. Ведь любая народная сказка - русская, чешская, польская, итальянская, английская передавала ребенку определенный исторический и культурный опыт, воспитывала его, соответственно, как представителя своего народа, а пролетарский ребенок должен был расти интернационалистом, поскольку родиной пролетариата становится весь мир.

Отношение кнародной сказке совершенно поменялось после Второй Мировой войны, когда народы и Советского Союза, и всего мира объединились в борьбе с фашизмом. В середине 50-ых гг. в России начали издаваться зарубежные сказки в новых переводах. О важности знакомства со сказками разных народов известный фольклорист и писатель-сказочник М.А.Булатов (1913-1963) писал: Нечего и говорить о том, какое исключительно важное значение имеет издание сборников сказок различных народов для детей. Ведь именно эти сказки с самого раннего возраста дают большой познавательный материал, помогают укреплению дружбы между народами, вызывают интерес к другому народу, уважение е его национальной «культуре». (Булатов 1955, 46).

В 40-ых-50-ых гг. XX в. в Советском Союзе появились переводы чешских, польских, итальянских, английских народных сказок, сделанные с учетом особенностей этих языков, передающие характерные черты культуры этих народов. 


\section{Чешские сказки в России 5}

Интерес к чешским сказкам в России зародился в середине XIX в., когда российская читающая публика познакомилась с творчеством замечательной чешской писательницы Божены Немцовой. С ней планировали сотрудничество представители славянофильских кругов, в частности Пыпин и писатели Н.С.Лесков, И.С.Аксаков, знаменитый филолог-славист И.И.Срезневский. Фольклорист А.Ф.Гильфердинг был лично знаком с писательницей. Славянофилов в Божене Немцовой привлекали «живой интерес к жизни и культуре славянских народов, страстное стремление содействовать сближению славян, деятельность фольклориста-собирателя, популяризатора произведений народного творчества и знаний о жизни народа» (Карская 1969, 4). Неудивительно поэтому, что первой чешской сказкой, опубликованной в России, оказалась сказка «О двенадцати месяцах», записанная чешской писательницей.

Сказка «О двенадцати месяцах» вышла в журнале «Северная пчела» в марте 1863 г. Переведена она была с чешского языка Н.С.Лесковым, писавшим под псевдонимом «М. Стебницкий». Перевод был сделан в Париже, завершен, как указано рядом с подписью переводчика, «25 декабря 1862 г.» (Немцова 1863, 10). В примечании кпереводу говорится «Pohadka “O Dvanásti mesickách” записана известной чешской писательницей Божиной Немцовой, с уст народных, и напечатана в литературном сборнике, изданном в Праге, под названием "Lada Niola". В переводе, по возможности, удержан строй народной речи, неподражаемо верно переданный в оригинале» (Немцова 1863, 1).

В 1898-1899 гг. в Петербурге были изданы на русском языке сборники чешских исловацких сказок, снабженные многочисленными иллюстрациями (Иванова 1990, 466). Таково, например, издание, которое так и называется: «Чешские сказки, собранные Карлом Эрбеном и Боженой Немцовой» (ЭрбенНемцова 1897). Книга была издана в 1897 г. в Петербурге. Переводчицей с чешского языка выступила детская писательница М.А.Лялина. Сборник сказок 1897 г. фактически состоит из двух частей, что видно из его содержания (Эрбен-Немцова $1897,287)$. Хотя в тексте самой книги нет никакого деления на части, сказки, собранные К.Эрбеном и Б.Немцовой, опубликованы двумя блоками. Благодаря этому изданию, российские читатели познакомились с такими чешскими сказками, как «Высокий, Широкий и Зоркий», «Златовласка», «Язинки», «Три золотых волоса Деда-Всеведа», «Лесная женка», «Ум исчастье», «Три пряхи», записанными

\footnotetext{
${ }^{5}$ Данные обо всех сборниках сказок, упоминающихся в статье, приводятся по каталогам Российской Государственной Библиотеки (Москва) и Российской Национальной Библиотеки (Санкт-Петербург).
} 
К.Эрбеном, а также «Солнышко, Месячко и Ветричко», «Добрунка и Злобога», «Небесный спутник», «Бесстрашный Микеш», «Чудотворный меч», «Дочь русалки», записанными Б.Немцовой.

В 1912 г. в Москве выходит следующее издание чешских сказок - «Божена Немцова. Чешские народные сказки» (Немцова 1912). Перевод был сделан заново Анной Ивановной Гржимали-Егоровой (01.06.1877-1960), женой известного русского математика Д.Ф. Егорова. Чешка по национальности, Анна Гржимали родилась и выросла в России ипрекрасно знала оба языка, русский ичешский. В книгу, переведенную ею, вошли сказки "О двух братьях», «Как Яромил счастье нашел», «О трех заколдованных собаках», «О Маришке», «Крестный». Заново были переведены сказки две сказки - «Неустрашимый Микош» (в 1897 г. - «Бесстрашный Микеш») и, видимо, «Русалка» (в 1897 г. - «Дочь русалки»).

Издания сказок, записанных Боженой Немцовой, имеют свою отдельную историю в России. Сборники сказок из ее собрания выходили в России под названием «Золотая книга сказок» (Л, 1978; М, 1993, Новосибирск, 1993, М, 2016, 2018) и «Серебряная книга сказок» $(С П б, 2016)$. Иногда обе книги выходили под одной обложкой (М, 1996, Красноярск, б.г.). В виде тонких книжек для маленьких читателей с множеством картинок публиковались и отдельные сказки: «Пастух и рыцарь» (М-Л, 1951, Свердловск, 1961), “Счастье Яромила» (М., 1974, 2017), «Король времени» (Курган, 1992). В 1961 г. вышел сборник «Немцова, Божена Сказки. Повести. Рассказы» (М-Л, 1961), рассказывающий о разных сторонах творчества Божены Немцовой, включая и собранные ею сказки.

После революции 1917 г. в издании и переводе чешских сказок в России по причинам, изложенным выше, наступил перерыв. Снова советские дети смогли познакомиться с ними только в 1948 г., когда вышла книга «Эрбен К.я. Баллады. Стихи. Сказки» со вступительной статьей, рассказывающей о жизни и творчестве чешского писателя. Сказки вэтой книге были представлены как иллюстрация деятельности Карела Эрбена - исследователя, собирателя и издателя народных сказок.

Издание 1951 г. предназначалось «для младшего возраста» (Чешские народные сказки 1951, 104). Сказки переводились с чешского языка переводчиками М. Зельдович, С.Шмераль, В.Ветлиной, Т.Аксель. В книгу были включены сказки, собранные Б.Немцовой «Пастух и рыцарь», «Мудрый ювелир», «Кум Матей и кум Иржи» (в издании 1897 г. «Кум Матей»), «Счастье Яромила» (в издании 1912 г. «Как Яромил счастье нашел»). Из собрания К.Эрбена были выбраны «Школа приносит богатство», «Король Хорек», «Догадливый Куба» и «Золотоволоска». Находим здесь же и сказки, не только впервые переведенные, но и обработанные 
(«перевод и обработка» (Чешские народные сказки 1951, 104)), например, «Гонза и хозяин», «Валибук и красавица-цыганка», «Янко-крепыш», «Крестьянин и купцы», «Франта, Вашек и Гонза», «Ученый пес». Сказки вышли с иллюстрациями художника В.Минаева в твердом переплете.

Через три года, в 1954г., часть сказок, вошедших в издание 1951 г., была переиздана в серии «Книга за книгой». Это издание вышло под названием «Златовласка. Чешские народные сказки». В него вошли сказки «Златовласка», «Янко-крепыш», «Ученый пес», «Гонза и хозяин».

Сразу дважды чешские сказки издавались в 1956 г.: в Москве как отдельный сборник «Чешские народные сказки» (в пер. М. Таловой) (Чешские народные сказки 1956) и в Ленинграде как часть книги "Славянские сказки», куда, кроме чешских сказок, вошли еще сказки Болгарии, Польши и Югославии (Славянские сказки 1956).

Чешские сказки издавались не только в Москве и Ленинграде. В 1962 г. в Саратове был издан сборник под поэтическим названием «Сказки Золотой Праги» (Сказки Золотой Праги 1962).

В середине 70-ых гг. XX в. российские дети познакомились с новым изданием чешских сказок. Уникальность этого издания состояла в том, что издание было подготовлено и осуществлено в Праге, в издательстве «Артия» (Чешские сказки 1974), то есть представляло собой чешский взгляд на то, какие сказки будут приняты русскоязычной аудиторией. Составлен этот сборник был Иржи Гораком, переводчицей выступила Л.Рюрикова. Еще раз подобный сборник, «Чешские сказки», был издан в Праге только в 2007 г. (Чешские сказки 2007). В него вошли лучшие сказки из собраний Божены Немцовой и Карела Эрбена в переводах Екатерины Бобраковой-Тимошкиной.

В самом начале перестройки, в 1990 г., чешские сказки (вместе со словацкими) наконец-то дождались серьезного, критического издания, рассчитанного не только на детей, но и на взрослых читателей, специалистов по славянскому фольклору (Чешские и словацкие народные сказки 1990). Кроме того, что в книгу вошло большое количество новых, качественных переводов, она была снабжена академической статьей И.Ивановой, рассказывающей о собирании чешского и словацкого фольклора и о его особенностях.

90-ые гг. XX в. были, с одной стороны, нелегким временем для книгоиздателей, хотя и давали им определенную свободу, с другой, были снижены критерии издательского дела. Во втором номере альманаха «Почитайка», издававшемся в Самаре (тираж 75 000) и посвященном славянским сказкам, сказка «Златовласка» вышла без упоминания имени К.Эрбена, с подзаголовком «чешская сказка» («Почитайка»,№2 1994). Можно было бы оправдать такое упущение 
издателей тем, что альманах рассчитан на малышей, но ведь и серия «Книга за книгой», в которой в 1954 г. вышла «Златовласка», тоже была предназначена младшим школьникам, а имя чешского писателя-фольклориста было упомянуто.

Новый век ознаменовался двумя значительными по объему изданиями чешских сказок. Первое из них «Сказания древней Чехии» вышло в 2000 г. в серии «Легенды, предания и сказки народов Европы» (Сказания древней Чехии 2000). В книгу вошли переводы М.Таловой иФ.Боголюбовой. Издание этой книги было поддержано Федеральной программой поддержки книгоиздания России. Второе издание до некоторой степени возвращает нас к началу пути: в 2013 г. снова были изданы сказки, записанные К.Я.Эрбеном. Они вышли под названием «Златовласка: чешские волшебные сказки» в новом переводе Ольги Акбулатовой и предназначены детям среднего школьного возраста. В то же время издаются и отдельные сказки Карела Эрбена в виде иллюстрированных книг увеличенного формата, рассчитанные на маленьких читателей: «Горшочек, вари!; Ум и Счастье» (M, 2013) и «Три золотых волоса Деда Всеведа» (М.,2014), известная еще по изданию сказок 1897 г.

Хотя чешские сказки в России читают уже около полутора столетий, самой популярной и известной из них оказывается «Златовласка», записанная Карелом Эрбеном. Можно сказать, что для российских читателей она стала символом чешской сказки. Как говорят на читательских форумах: «Самая известная унас в стране чешская сказка про доброго слугу Иржика и принцессу Златовласку» (6), «Известнейшая (да, наверное, самая известная у нас) чешская народная сказка “Златовласка"» (6). Поколения советских, а затем российских детей росли, читая ее или слушая запись на пластинке: «В далёком детстве была у меня пластинка с этой сказкой ... слушала часто. Иржик и Златовласка мне очень нравились. Купила книгу ... при прочтении стала замечать, что читаю с такой же интонацией как и на той пластинке. Прям мурашки по коже» (6). Как правило, эту сказку читают младшие школьники, видимо, в качестве задания по внеклассному чтению. На сайтах школ, где открыты персональные страницы учеников, есть отчеты о прочтении этой знаменитой сказки: «Мне понравилась эта сказка, потому что она поучительная. <...> В конце сказки добро побеждает. А коварство и зависть в лице короля погибают!» (1); «Больше всего мне понравилось, как звери помогали Иршику во всех его бедах» (2). Иногда запись содержит и краткий пересказ текста «Златовласки», и выводы, к которым ребенок пришел, прочтя сказку: «Главная мысль сказки «Три золотых волоска» ${ }^{6}$ заключается в том, что доброе отношение кдругим людям всегда возвращается ответными добрыми делами. Иржик помог муравьям, воронятам,

\footnotetext{
${ }^{6}$ Другой перевод названия сказки «Златовласка».
} 
золотой рыбке и мухе, и они оказали ему ответную помощь. Сказка К.Эрбена учит быть внимательным по отношению к людям, уметь распознавать коварных людей» (3). Среди прочих сказок «Златовласка» оказывается одной из наиболее привлекательных для ребенка, еще не умеющего читать. Так, в отзыве о книге «Златовласка. Чешские волшебные сказки», изданной в Москве в 2013 г., читательница пишет: «Закончили читать книгу "Златовласка"... Дочка читала лишь небольшие части сказок, остальное предоставляла читать мне... Среди них дочка отметила понравившиеся...» (4). Одной из понравившихся сказок оказалась «Златовласка». Почему российским детям так нравится эта сказка? Ответы находим на читательских форумах: «Эта сказка учит не бояться трудностей. Надо всегда помогать другим в сложной ситуации» (5), «В сказке «Три золотых волоска» мне понравился главный герой, Иржик. Это честный, добросовестный и доброжелательный человек» (3), «Неторопливый поэтический рассказ о благородстве, взаимопомощи, любви» (6). «Златовласка» настолько известна в России, что на детских конкурсах, посвященных чешскому языку ичешской культуре, встречаем задание - дописать продолжение этой сказки (15).

Популярности сказки «Златовласка» способствовал и чешский фильм, снятый в 1973 г. режиссером Властой Яничковой. В 70-ых-90-ых гг. на советском (позже российском) телевидении каждое воскресенье шла передача «В гостях у сказки» с ведущей Валентиной Леонтьевой, «тетей Валей», «самая любимая передача не только детей, но и взрослых» (7), которую и дети, и их родители всегда ждали с нетерпением. Целью этой передачи был показ фильмов-сказок, и «Златовласку» включали в программу показа трижды - в 1976/77 гг. (первый сезон), в 1978/79 гг. и в 1983/84 гг. Шел он и в кинопрокате: «Работники кинотеатров советского периода вспоминают, что во время кинопроката этой сказки залы кинотеатров были забиты школьниками - многие приходили посмотреть сказку три-четыре раза» (9). С появлением интернета фильм появился на многочисленных сайтах. Там же можно найти и отзывы зрителей, свидетельствующие о том, как экранизация «Златовласки» была принята публикой. Как и сказка, фильм стал знаковым в советской культуре: «Культовая для советских детей экранизация чешской волшебной сказки» (10), «Один из лучших детских фильмов застойного советского периода» (11), «Гениальный фильм!!! Обожаю!!!» (11). Для многих поколений советских, а затем и российских детей чешский фильм вызывает воспоминания о раннем детстве и о просмотре по телевизору, что приводит на мысль дом или детский сад: «Добрая, волшебная, уютная сказка из времен передач с тетей Валей» (12), «Смотрел еще в детском саду в программе «В гостях у сказки». Очень эту сказку тоже люблю. Люблю Златовласку и Иржика. Недавно 2 года назад посмотрел» (12), «До сих пор 
помню тоненькие голоса муравьев, разговаривающих с ним. Да и Златовласку с ее роскошными золотыми волосами трудно забыть. Когда я был маленьким, очень любил эту и другие киносказки, если были в телепрограмме - всегда смотрел. Я даже не могу представить свое детство без этих сказок, без доброты и тепла, шедшего с экрана телевизора» (12). Первые зрители, смотревшие этот фильм еще детьми в 70-ых-80-ых гг., рассказывали о нем своим детям и пробудили интерес и к нему, и к самой сказке: «Моя мама смотрела в детстве «Златовласку». У меня есть такая книга; я сначала прочитала, а потом решила посмотреть» (13). Что же для зрителей оказывается важными составляющими волшебной сказки? «В ней есть злой король, прекрасная принцесса, добрый юноша, невыполнимые задания. А, главное, умение понимать язык животных, живая и мертвая вода. И, конечно же, песни!» (10). Отмечается и воспитательное значение фильма: «как детский фильм, он, безусловно, научит помогать в беде всему живому, выполнять данные обещания» (10). Возможно, в детстве авторы отзывов не особенно обращали внимание на игру актеров, но, став взрослыми кинозрителями, они оценивают фильм и с этой точки зрения: «Хороший добрый фильм. Хорошо подобраны актеры. Очень хорошо переданы чувства фильма. Одним словом - Молодцы!» (12), «Прекрасная Златовласка в исполнении Йорги Котрбовой получилась такой, какой идолжна быть девушка, обладающая волшебным сокровищем - золотыми волосами: осторожной, доброй, красивой и способной на самопожертвование» (9), «Старый король получился капризным, подловатым, подозрительным, жестким, а отец Златовласки - немного чудаковатым, но, в сущности, добрым, и по-отечески влюбленным в своих дочерей» (10). Советским детям, не выезжавшим за рубеж, чешский фильм давал возможность перенестись в далекие страны, наслаждаться «прекрасными пейзажами Чехословакии, ее замками, зеркальным озерами, лесами и полями» (9). Как вспоминает один из кинозрителей, “... Было в них [в чешских фильмах-сказках, в том числе и в «Златовласке» - М.Н.] какое-то особое очарование, может от того, что снимали их на фоне настоящей готической архитектуры, может от того, что чешским режиссерам лучше удавалось изображать королевскую жизнь...» (14). Поэтому посещение места, где снимался фильм, ощущается как особое, удивительное событие: «Я была в этом замке, где снимали «Златовласку»!!!» (11). И до сих пор фильм «Златовласка» открывает Чехию, чешскую культуру, чешскую сказку маленьким россиянам.

Если говорить о собирателях сказок, то больше всего в России, наверное, известно имя Божены Немцовой, поскольку собранные ею сказки под названиями «Золотая книга сказок» и «Серебряная книга сказок» переиздавались в России неоднократно: «Замечательная книга - хорошо что переиздали!» (15), «Для меня 
большое счастье купить книгу, которая была одной из любимых в моей домашней библиотеке. Я и сейчас помню, какое она производила на меня впечатление, когда я её читал. Это что-то особенное. Страх, перемешанный с любопытством. Волшебство, не иначе» (15), «Одна из самых любимых книг детства» (21), «Отличное переиздание вечной классики!» (17). Как видим, чешские сказки остаются любимым чтением россиян, книгами, «знаковыми» (18) для них.

\section{Польские сказки в России.}

Первый сборник польских сказок был издан в Санкт-Петербурге, в 1880 г. Как утверждает автор предисловия кнему, доктор О.Гримм: «У нас существуют переводы сказок немецких, шведских и датских, но до сих пор, сколько мне известно, не было издано сказок славянских национальностей, за исключением немногих чешских легенд, рассеянных в разных изданиях» (Польские сказки 1880, v). Таким образом, можно считать, что польские сказки были первыми славянскими сказками, изданными в виде книги, а не в виде журнальных публикаций. В основу сборника доктора Гримма были положены сказки, записанные К.В.Войцицким и К. Балинским. Российские читатели познакомились тогда с такими сказками, как «Беда и нищета», «Поветрие», «Рыцарь с заячьим сердцем», «Троян», «Заколдованные глаза», «Хрустальная гора» и другими, в переводе писательницы К.Одынец.

В 1897 г. был издан следующий сборник польских сказок. Если в первом сборнике было всего 92 страницы исказки были взяты из коллекций двух фольклористов, то сборник 1897 г. насчитывал уже 312 страниц и кименам К.Балинского и К.Войцицкого прибавились имена других польских фольклористов А.Глинского, А.Дыгасинского, И.Крашевского, В. Пржиборовского, З.Моравской. Сказки, входившие в первый сборник, были переведены заново: «Беда и нищета» (1880) - «О беде и нищете» Войцицкого (1897), «Поветрие» (1880) - «О поветрии» Балинского (1897), «Рыцарь с заячьим сердцем» (1880) - «О рыцаре с заячьим сердцем» (1897), «Троян» (1880) - «О царе Траяне» Балинского (1897), «Заколдованные глаза» (1880) - «О пагубных глазах» Войцицкого (1897), «Зефир» (1880) - «О царевиче Зефире» Балинского (1897).

Сборник сказок 1897 г., богато иллюстрированный и в твердом переплете, был доступен, видимо, только достаточно обеспеченным людям. Для народа, для бесплатных сельских библиотек и читален, польские сказки были изданы в 1899 г. под №97 в серии «Иллюстрированная сказочная библиотека Ф. Павленкова». Книжечка «Польские сказки» (СПб, 1899), стоившая 15 копеек, включала в себя три 
сказки в переводе Т.С.Якубовского - «Цветок папоротника», «Чудесный грошик», «Волшебная скрипка».

Особую группу сказок, в частности, польских, составляют сказки и легенды, героями которых становятся Христос, Пресв.Богородица, святые. В Москве в 1911 г. вышла небольшая книга, подготовленная двумя видными деятелями польской культуры, писателем и драматургом Марианом Гавалевичем (1852-1910) ихудожником Петром Стахевичем (1858-1938). Книга называлась «Польские народные Легенды о Богородице». Сами легенды были так охарактеризованы их собирателем М.Гавалевичем: «... легенды о Божией Матери, издавна создаваемые воображением нашего народа и сохраняемые в заветном ковчеге его от самых старых до новейших времен. Затаенные в этой сокровищнице, мерцали они таинственным блеском, светились как червяки Ивановой ночи, благоухали запахом лесных ландышей иполевой богородицыной травки ипод этой деревенской простотой скрывали великолепие драгоценных камней, просивших яркого солнца, чтобы заиграть цветами радуги и вспыхнуть румянцем утренней зари» (Гавалевич 1911, I). Текст книги был прекрасно переведен на русский язык известным поэтом Владиславом Ходасевичем, который равно владел русским и польским языками.

Сборник «Польские сказки» 3.Карабановой, вышедший в Москве в 1914 г., по объему почти не уступает сборнику 1897 г. В нем 292 страницы, и все сказки за исключением одной - «Княжич-ворон» («Ворон» в издании 1880 г., "О царевиче вороне» в издании 1897 г.) были переведены на русский язык впервые. Это, например, такие сказки, как «Валигора и Вырвидуб», «Чудный перстень», «Заколдованный замок», «Мудрая королевна», «Золотые груши», «Малиновый домик», «Смерть-крестная мать», «Королевич Лель».

После длительного перерыва сборник польских сказок под названием «Гороховый Стручок - Огородный Старичок. Польские народные сказки» вышел в 1953 г. в издательстве «Детгиз» (М-Л, 1953). Сказки там опубликованы в пересказе (Гороховый Стручок 1953, 80), то есть не только в переводе, но и в обработке. В содержании указаны имена переводчиков, адаптировавших тексты сказок для младшего школьного возраста: Н.Белинович и К.Дунин-Борковский. Как кажется, из сказок, уже известных по ранним сборникам, выбрана и заново переведена одна «Король-мужик» («О мужичке-короле» Крашевского в издании 1897 г). Выбор продиктован, видимо, господствовавшей тогда идеологией. Сказка, давшая название всему сборнику, «Гороховый Стручок - Огородный Старичок», была переиздана спустя два года в Чите (Чита, 1955). Там же, в 1958 г. вышла книга польских сказок «Пастух тысячи зайцев» (Чита, 1958) объемом 91 страница, а в 1960 г. - сборник «Цветок папоротника» (Чита, 1960) объемом 102 страницы. 
В обоих случаях переводчицей выступала Л.Пивоварова. Выбор такого места издания польских сказок не случаен: за последние двести лет в результате ссылок до 1917 г. и во времена репрессий 30-ых гг. XX в. в Сибири образовалась огромная польская община, и, соответственно, польские сказки были востребованы местной читательской аудиторией. Польские сказки издавались не только на востоке, в Чите, но и на западе, в Калининграде («Как мужичок Бурачок пана в дураках оставил. Зимовье зверей», Калининград, 1961. Серия «Шкатулка сказок»).

Поворотным годом в издании польских сказок стал 1965 г., когда вышло в свет первое в истории перевода польских сказок их критическое издание, рассчитанное не только на детей, например, среднего и старшего школьного возраста, но и на специалистов-славяноведов - «Польские народные легенды и сказки» (М., 1965). В книгу включена статья советской полонистки и переводчицы Янины Мацюсович. Весь корпус сказок организован в разделы: «Легенды и предания», “Сказки о животных», «Бытовые сказки, анекдоты и шутки», причем есть и небольшой раздел «Указатель источников», где указаны первые публикации сказок в Польше с выходными данными (с 1867 г.).

Как и в случае с чешскими сказками, советские дети смогли прочитать книгу сказок, отражающую польский взгляд на то, какие сказки наиболее типичны для польской народной культуры, - книгу «Королевна-волшебница и другие польские сказки», вышедшую в Варшаве, в издательстве «Полония», в 1966 г.

До начала 90-ых гг.XX в. в СССР вышли еще два больших издания польских сказок: для младшего возраста «Там, где Висла-река» (М, 1975), в которую были включены ипересказы ранее переведенных сказок (например, «Цветок папоротника», «Пастух, который тысячу зайцев пас») и новые переводы и обработки, и второе критическое издание сказок «Польские народные сказки» (Л, 1980). В издании 1980 г. воспроизведена статья Янины Мацюсович, но больше половины сказок переведено впервые. Как и в издании 1965 г., сказки разнесены по разделам, но разделов теперь больше: «Сказки о животных», «Волшебные сказки», «Сказкишутки, сказки-анекдоты», «Сказки-рассказы», «Легенды, предания и поверья».

В самом начале 90-ых гг., в 1992 г., в России выходят два больших собрания польских сказок - «Польские сказки» (Тула-Нижний Новгород, 1992, 253 страницы) и одноименная книга в серии «Антология сказок» (т.4, СПб, 1992; 300 страниц). До настоящего времени нового отдельного издания польских сказок в России не выпускали, хотя, конечно, они входят наряду со сказками других народов в различные сборники, например, «Сказки народов мира» (M, 2006), предназначенные «для чтения родителями детям», куда включены сказки славян (белорусские, украинские, чешские, польские, болгарские, сербские), немецкие, 
французские, итальянские, английские сказки, а также сказки народов Дальнего Востока.

При том, что, как кажется, польские сказки довольно часто издавались и до 1917 г., когда часть польских земель входила в состав Российской империи, и в 50-90-ых гг. XX в., они не стали привычным чтением в России: «... какие польские народные сказки вы знаете? С большой вероятностью можно предположить, что большинство россиян ответит на него одинаково: «никаких». А жаль! Ведь в сказках живёт душа народа, нравственное наследие его предков, культурный и цивилизационный код. А, кроме того, между сказками, мифами и легендами разных народов много общего, изнание об этом может облегчить взаимопонимание между соседними странами» (18). Однако не все так безнадежно. Основные издания польских сказок - 1965 и 1980 гг. - выложены в интернете полностью, на различных сайтах, посвященных сказкам, также есть польские разделы (19). На одном из сайтов отмечен рейтинг сказок по отзывам читателей 4,2 из 5, что довольно высоко в ситуации, когда нужно читать текст с экрана компьютера (20). Находим и читательские отзывы, например, о сказке «Плащневидимка», причем заметно, что читательница сопоставляла эту сказку с известным каждому россиянину текстом Н.В.Гоголя: «Ах, какая любопытная сказка! Во-первых, такой замечательно сконструированный мистический сюжет, до мурашек по спине. Во-вторых, настолько каноническая кровососущая нежить в произведении устного народного творчества, что крайне интересно само по себе. А в-третьих, это же просто гоголевский "Вий" почти один в один, только со счастливым финалом» (22). Однако наиболее часто польские сказки находят путь к читательской аудитории как материал для домашнего чтения при изучении польского языка: «...ценность данного издания сложно преувеличить. Будет очень полезна для дополнительных занятий при изучении польского языка» (21), «Очень импонирует эта серия - тем, что оригинальный текст не адаптирован, не сокращен» (21), «Очень хорошая и полезная книга. Для тех, кто изучает язык - это просто находка» (21). Как кажется, чтение сказок в оригинале - прекрасный выход из положения, поскольку читатель лучше понимает не только содержание сказки, но и погружается в атмосферу польского языка и культуры.

\section{Итальянские сказки в России.}

С Италией Россию связывают давние культурные связи, ставшие особенно прочными в XVIII в, в правление Петра І. Следующее столетие видело многих представителей российской творческой интеллигенции, художников и писателей, приезжавших 
в Италию и иногда остававшихся в Италии навсегда. Так, в Риме была колония русских художников, некоторые жили там постоянно, другие, так называемые пенсионеры академии Художеств, ехали в Вечный город для завершения образования. Италию посещали ижили в разных ее городах русские поэты и писатели Евгений Баратынский, Константин Батюшков, Николай Языков, Федор Достоевский, Николай Гоголь, Иван Тургенев. Неудивительно поэтому, что итальянские сказки занимают совершенно особенное место в русской культуре.

В издании итальянских сказок в России сложилась определенная традиция. Существует как бы несколько основных «ветвей» и отдельные тоненькие веточки, вырастающие из одного корня.

Надо сказать, что первые итальянские сказки, с которыми познакомилась российская читательская публика, не были народными. Они принадлежали перу писателя и сказочника Луиджи Капуана (1839-1915), прекрасно знавшего итальянский, в частности сицилийский, фольклор. В 1894 г. в Санкт-Петербурге была издана книга сказок Л.Капуано под традиционным для России названием «.. Жили были...». Сказки были переведены с итальянского языка Е. Левицкой-Рогаль под редакцией писателя Н.Арепьева. Издание Капуано было переведено еще раз, но не полностью, в 1912 г. Марией Андреевой, секретарем и гражданской женой Максима Горького, причем Горький принимал участие в редактировании перевода. Перевод М.Андреевой был издан двумя томами. В первый том вошли сказки «Фея-цветок», «Сказка о золотом перышке», «Баба Яга», «Король Гром», «Мастер что починит - что испортит», «Дочь людоеда», «Куколка». Пять сказок оказались включенными во второй том: «Иголка», «Гипсовый котик», «Сковородка», «Мельник», «Сверчок». Переводы М.Андреевой выполнены в старинной русской переводческой традиции, сложившейся еще в XVIII в. Согласно этой традиции иностранные тексты предполагалось для лучшего понимания читателями переделывать «на русский лад". Поэтому в переводах М.Андреевой встречаем такие слова и выражения, как «зыбка» (Итальянские сказки-1 1912, 45), «барыня» (Итальянские сказки-1 1912, 53; Итальянские сказки-2 1912, 5), «Баба Яга» (Итальянские сказки-1 1912, 45), «скатываться с лестницы кубарями» (Итальянские сказки-1 1912, 70), «ни отдыха, ни срока» (Итальянские сказки-1 1912, 4). Цены на итальянском рынке неожиданно исчисляются в «рублях»: «сто рублей» (Итальянские сказки-1 1912, 128), «триста рублей» (Итальянские сказки-1 1912, 128), а разговор героинь приобретает русское простонародное звучание: “ - Кого ты там в окошко высматриваешь? - А королевича!» (Итальянские сказки-1 1912, 4). Сказки Капуано в переводе Марии Андреевой были полностью включены в книгу «Итальянские сказки» (М, 1991), составленную Н.В.Котрелевым и вышедшую тиражом 500000 экземпляров. 
Сказки Луиджи Капуано имеют свою традицию издания. Как кажется, в начале 90-ых гг. (в выходных данных отсутствует год издания) они вышли в издательстве «Радуга» с пометкой «для дошкольного имладшего школьного возраста» в пересказе Л.Вершинина (Луиджи Капуана. Сказки. Тверь-Москва, б.г.), а к столетию первого издания его сказок петербургское издательство «Милета» переиздало перевод Е. Левицкой-Рогаль.

Следующая «ветвь» представляет собой переводы русской дореволюционной писательницы Евгении Михайловны Чистяковой-Вэр. В 1907 г. в Санкт-Петербурге вышел сборник "Итальянские сказки», собранный и обработанный ею. Несколько итальянских сказок вошло и в ее книгу «Сказки бабушки про чужие странушки» $(С П б, 1912)$ наряду со сказками и историями других народов. В составе этого сборника они издавались еще в 1992 и 2015 гг.

«Ветвь» Итало Кальвино начинается с издания, рассчитанного не только на широкие читательские круги, но и на специалистов, поскольку в этом сборнике указывается, в какой области Италии была записана та или иная сказка. В аннотации к книге говорится: «В настоящем издании представлены переводы избранных сказок из сборника «Итальянские сказки, записанные втечение последних ста лет, обработанные и переведенные с диалектов на современный язык Итало Кальвино». Издательство Джулио Эйнауди, 1956 г.» (Итальянские сказки 1959, 2). Сказки, собранные И.Кальвино, были переизданы в 1991 г. Под названием «Волшебные сказки Италии» в новом переводе А.Печерской часть этих сказок была издана в Москве в 2014 г.

На волне издательской политики 40-50-ых гг. XX в. был издан сборник сказок, ставший, пожалуй, наиболее популярным из всех упоминающихся в этом разделе изданий, - «Три апельсина», который определяется как «сборник бытовых и волшебных сказок» (Три апельсина 2016, 4). Переводчицами выступили Ю.Ильина и Э.Казакова, но сказки были еще и пересказаны Н. Гессе и 3. Задунайской. Готовился этот сборник постепенно: некоторые переводы издавались сначала в литературных журналах. Так, например, сказка «Скворцы и дрозды» в переводе Э.Казаковой и пересказе Н. Гессе была отдельно опубликована в так называемом «толстом» журнале «Нева» (№9, 1957, 215-216), а сказки «Огонь, вода и честь» и «Богатое приданое» в переводе Ю.Ильиной и пересказе Н.Гессе вышли в журнале «Вокруг света» (№11, 1958, 27-28). Первый вариант этой книги вышел в Москве до 1949 г. в издательстве ОГИз (1930-1949), после чего в Ленинграде «Три апельсина» переиздавались еще два раза - в 1960 и 1969 гг. Одна из сказок из этого сборника, «Синьора Сосиска», была издана тоненькой книжечкой увеличенного формата с цветными иллюстрациями (Л, 1973). После перестройки эта книга издавалась 
в разных городах: ВСанкт-Петербурге в 1992 и 2016, в Москве в 1993 и 2006, в Петрозаводске (Карелия) в 1993 г. Часть сказок из сборника «Три апельсина» вошла в книгу «Сказки. Русские народные сказки. Казахские народные сказки. Итальянские народные сказки», вышедшую в издательстве «Союзинформкино» (М, 1991). Цель этого сборника состояла в том, чтобы пробудить интерес к сказкам у возможных сценаристов мультфильмов: «есть среди нас люди, которые возвращаются к сказкам снова и снова - это режиссеры, актеры, художники словом все те, кто делает детские фильмы» (Сказки 1991, 2).

Сборник сказок под схожим названием - «Любовь ктрем апельсинам» выходил в Москве в 2014 и 2015 гг. Хотя переводчицей там значится Е.Широнина, обрабатывали сказки Н. Гессе и 3. Задунайская. Видимо, вариацией все того же сборника «Три апельсина» являются издания «Сказки Италии» (M, 2004) и «Итальянские сказки» (М, 2017). На такую мысль наводит состав авторов: «перевод с итальянского Ю. Ильиной, Э. Козаковой в пересказе Н. В. Гессе, 3. М. Задунайской»

В 50-ых гг. XX в. в России начал работать такой переводчик с итальянского языка, как упоминавшийся выше Лев Александрович Вершинин (1926-2013), переводивший сказки Л.Капуана. Ему принадлежат переводы сказок «Тредичино» (М, 1957) и «Ленивая Бручолина» (M, 1961), пересказанные для детей дошкольного возраста. Благодаря Л.Вершинину советские дети познакомились со сказками из собрания Джузеппе Питре, записанными им на Сицилии. Сборник под названием «В моих краях» (M, 1972) также предназначался для дошкольников. Еще одним сборником итальянских сказок, переведенных и обработанных Л.Вершининым для детей того же возраста, стал «Альбероне - герой» (М, 1977).

В 2011-2013 гг. выходили итальянские сказки для детей младшего школьного возраста в пересказе переводчика Леонида Львовича Яхнина: «Кикибио и журавль», «Ленивая Бручолина», «Тредичино», «Джеппоне», «Польдино и судья» и другие (Яхнин 2011), а также сборники для самых маленьких (для детей до трех лет): «Находчивая девушка», «Преццемолина», «Веселый Монакиккьо», «Лежебока» (Яхнин 2012, 2013), напечатанные и в сборнике 2011 г.

Еще один сборник - «Хитрый Камприано» - представляет собой собрание новых переводов сказок из книги Итало Кальвино, например, «Борода Графа», «Красавица Фанта-Гиро», «Я люблю тебя, как соль», «Ешь, моя одежка!», «Одна ночь в раю», а также сказок, переведенных впервые, - «Семиглавый Дракон», «Чикко Петрилло», «Как хитрец Ферраццано посмеялся над Королевой», «Крикке, Крокке и Манико Унчино» и другие (Хитрый Камприано 2018). Переводы выполнены Натальей Михайловной Сухановой. Первое издание книги было выпущено 
в 1993 г. (Москва-Пермь, 1993) тиражом 200000 экземпляров, а в 2018 г. книга была переиздана в серии «Дар речи» (СПб-М, 2018).

Как ипольские сказки, сказки итальянские приходят кчитателям и в оригинале, поскольку они успешно используются при изучении итальянского языка как в качестве домашнего чтения. Таково, например, учебное пособие, составленное Л.Бевз, «Итальянский язык с Итало Кальвино "Волшебное кольцо"» (M, 2007). Текст сказок дается параллельно по-русски ипо-итальянски для самостоятельного изучения языка по методу чтения Ильи Франка. Книга «Подарок северного ветра» (СПб, 2015) представляет собой сборник адаптированных итальянских сказок с комплексом упражнений, который предназначен для углубленного изучения языка.

Для многих российских читателей сказки стали «первым знакомством с Италией» (23). Из всех перечисленных изданий итальянских сказок два оставили глубокий след в читательской памяти. В первую очередь, это конечно, сборник «Три апельсина», который читали и продолжают читать поколения советских, а позже и российских, детей: «У меня есть книга издания 1960 года, мой дед дарил ее моей маме :) потом книга досталась по наследству мне, а теперь я читаю ее дочке» (22), «Очень интересные сказки не только для маленьких. До сих пор их помню, хотя читали мне эти сказки еще лет 20 назад» (22). Сборник, выходивший в России несколько раз за 58 лет, стал частью самых светлых воспоминаний о детстве: «Такая книга была у меня в детстве. Как же я её любила! Все-все сказки в этом сборнике! <...> Я рассказывала их своим одноклассницам на уроках труда (были в моем детстве такие уроки), когда мы шили-вышивали. И чувствовала себя не хуже Шахерезады, потому что девочки с нетерпением ждали продолжения моих сказок-рассказок» (22). Однако и сказки, обработанные Итало Кальвино, которые вошли в издание 1991 г., столь же популярны: «Эта книга - одна из многочисленных вещей, о которых мне хочется говорить: "Если у вас ее не было вдетстве, то не было и детства". В каждой шутке есть маленькая доля шутки, однако, как показывает практика, сказки эти любили многие и перечитывали не по разу» (23). Читатели не только оставляют на форумах прочувствованные воспоминания, но и объясняют, что именно привлекает их в итальянских сказках: «Это прекрасные, поэтичные, солнечные сказки» (23), «итальянские сказки необычны, они отличаются от привычной формы народной сказки других стран. Здесь часто непредсказуемые сюжеты, более сложная композиция, более разнообразные темы» (22), «Каждая сказка больше напоминает притчу, потому как рядом с вымыслом уютно устроился дух доброты, честности и юмора. В каждой истории находишь что-то поучительное, отнюдь не детский и не сказочный смысл, который порой заставляет задуматься, 
а действительно ли это детская книга. Любовь, долг, коварство, дружба, преданность, осуждение лени и глупости - все это встречается на страницах книги, причем не в том приторно-конфетном виде, как в других сказках, а в форме разговора с ребенком практически на равных» (24).

\section{Английские сказки в России.}

Так случилось, что сами британцы стали поздно записывать свои сказки, и только в 1890 г. фольклорист Джозеф Джекобс опубликовал двухтомник «Английские народные сказки», переизданный в 1893 и 1896 гг. (Английские народные сказки $1957,4)$. Первый перевод английской сказки на русский язык появился очень быстро - в 1899 г. В Москве без указания имени переводчика была издана сказка «Карлик с длинными ступнями». Качество перевода невысоко. Переводчик, видимо, гораздо лучше знал французский язык, поэтому имя главного героя передано как «мистер Жорж» (Карлик 1899, 3), а не «Джордж».

Первое значительное собрание английских сказок вышло в 1908 г. в СанктПетербурге. Перевела их упоминавшаяся выше Евгения Михайловна Чистякова-Вэр. Переводчица намеренно включила в книгу не только народные сказки, но и отрывки из произведений английских и американских писателей, предназначенных детям, «чтобы мой сборник не вышел однообразным» (Английские сказки 1908, 3), «чтобы не утомить читателя однообразием» (Английские сказки 1908, 3). Народные сказки взяты из собрания «Т.Джекобса», но их названия показывают, что написание имени фольклориста ошибочно. Это, конечно, Джозеф Джекобс. Благодаря переводам Е.Чистяковой-Вэр маленькие читатели познакомились со сказками, которые неизменно включались и в более поздние сборники, например, "Джек и золотая табакерка», «Джек и великаны», «Готемские умники», "Джек и бобовый стебель», «Том мальчик с пальчик», «Колодец конца света». Кроме фольклорных текстов, переводчица включила в свой сборник отрывки из сочинений Р.Киплинга, Луизы Мей Олкотт, Элизы Скотт и некоторых других, забытых теперь авторов.

В «Золотой книге сказок всех стран инародов» (СПб-М, 1913) со вступительной статьей известного педагога и ученого, профессора А.Погодина среди прочих сказок был представлен перевод ранее не известной русским читателям сказки «Чайльд Уинд изаколдованная змея» иновые переводы сказок уже известных - «Джек или золотая табакерка», «Джек истребитель людоедов». В небольшой статье «От издателей» определялась не только цель издания («дать подбор характернейших и содержательнейших народных сказок всех стран света и всех времен» (Золотая книга сказок 1913, 5), но и формулировалась переводческая 
стратегия: «При переводе главное внимание обращалось не только на тождественность содержания, но и на сохранение по мере возможности, всех внутренних и внешних художественных особенностей каждой сказки. Илишь местами было прибегнуто к известной фильтрации для устранения некоторых элементов, по мнению педагогической критики, нежелательных и неуместных в книге, предназначенной для юношества. ... удалено все жестокое, грубое или двусмысленное, без всякого, однако, ущерба для ее образности и типичности» (Золотая книга сказок 1913, V-VI).

Публикация в одном издании авторских, литературных и народных сказок была обычна до 1917 г. В том же 1913 г., когда была издана «Золотая книга сказок», в Санкт-Петербурге был выпущен сборник под названием «Английские сказки», видимо, как литературное приложение кжурналу «Золотое детство». Сборник открывает “Алиса в Волшебной стране” (Л.Карроля)» (Английские сказки 1913, V), а остальные сказки взяты из фольклорных собраний, например, «Принцесса с золотым мячиком», «Три вора».

Дальнейшая история переводов английских сказок довольно проста. В 1957 г. был выпущен сборник английских народных сказок в переводах Натальи Викторовны Шерешевской, известной советской и российской переводчицы и писательницы. Практически все изданные позже сборники сказок либо воспроизводят это издание (как, например, одноименные издания 1960, 1992, 1993 гг.), либо включают в себя большую часть сказок из него, как сборники «Источник на краю света», впервые вышедший в 1969 г. и постоянно переиздающийся (последнее издание в 2017 г.), и «Сквозь волшебное кольцо» (М., 1987, 1988). Оба сборника представляют читателю сказки разных народов Британских островов. Английский раздел восходит к изданию 1957 г. Сказки в переводах Н.Шерешевской включены в сборник «Путешествие в сказку. Английские народные сказки» (М, 1993). Без указания имени переводчика английские сказки были опубликованы в уже упоминавшемся выше альманахе «Почитайка», адресованном детям младшего школьного возраста. Маленьким читателям были предложены такие сказки, как «Ленивая красавица и ее тетушки», «Джек и бобовый стебель», «Кэт-Щелкунчик», «Кто всех одолеет», «Как Джек ходил счастья искать» («Почитайка» №3 1994).

Лишь XXI век увидел новые переводы и обработки английских сказок. В 2009 г. было выпущена книга «Английские народные сказки» в пересказах Ю.Денисова (Английские народные сказки 2009). В книге публикуются обработанные Ю.Денисовым сказки из знаменитого собрания Джозефа Джекобса с краткими комментариями английского фольклориста к каждой сказке. Тем не менее, и этот 
сборник сохраняет связь с изданием 1957 г.: послесловие 2009 г. восходит к вступительной статье В.Важдаева, открывающей первое издание сказок.

Так же, как польские и итальянские сказки, сказки английские приходят к детям и в оригинале, хотя при этом их тексты обрабатываются в качестве учебного материала. Книги «Английские народные сказки» (издавались в 1985, 2003, 2005, 2006, 2007, 2008, 2009, 2010, 2012, 2013, 2014, 2016, 2017, 2018 гг.) и «Волшебные сказки Британии» (издавались в 2002, 2003, 2004, 2006, 2007, 2008, 2009, 2011, 2012, 2013 гг.), подготовленные В.А.Верхогляд и И.П.Твердохлебовой, считаются образцовыми учебными пособиями для домашнего чтения при изучении английского языка.

Как видно из рецензий на сборники английских народных сказок, эти сказки входят в жизнь российских детей в детстве, и память о них остается на всю жизнь: «Ох, наверное самая любимая книга детства» (24); «Шикарнейший сборник сказок, зачитанный мной почти до дыр (шучу, книга сохранилась в довольно хорошем состоянии). Бережно храню ее до сих пор. Книжные магазины маленьких северных городов в 80-е годы редко баловали такими сериями книг. И я с благодарностью вспоминаю, как папа, уезжая в командировки, большими стопками закупал детскую литературу и отправлял домой по почте. Эта книга - одна из многих, что пришла в одной из посылок с большой земли» (24); «Звук волынки, зеленые луга, затерянные замки и маленькие деревушки... Я до сих пор помню эти сказки - милые, добрые, действительно волшебные, своеобразные, совсем не похожие на русские, со своими героями <...> Уверена, что возвращусь к этой чудесной книжке, когда буду читать сказки своим детям» (24). Читатели видят в этих сборниках возможность познакомиться с особенностями английского фольклора: «однозначно её советую всем, кто любит фольклор» (25), «Каждый, кто увлекается британским фольклором, не должен проходить мимо» (25), а также с английской культурой, так сильно отличающейся от русской: «...не будут ли сказки живым и ярким дополнением к тем страноведческим знаниям, которые получаешь во время знакомства со страной. Будут! Однозначно !!!» (25).

\section{Заключение.}

Зарубежные сказки - чешские, польские, итальянские, английские - посредством переводов прочно вошли в культуру России и разделяли вместе с русскими сказками и запреты 20-30-ых гг., и интерес к фольклору разных народов, пробудившийся в 40-ых гг. Одни сказки известны поколениям советских и российских детей, как итальянские и английские, другие, как польские, не столь распространены. Иногда 
одна сказка, как «Златовласка», записанная Карелом Эрбеном, становится символом всего фольклора народа. Как бы то ни было, в России каждая сказка находит своего читателя, уча его добру, милосердию, справедливости. Большевистские, позже коммунистические, призывы к интернационализму, кбратству всех народов на земле, как кажется, благодаря сказкам трансформировались в гораздо более человеческие чувства. Еще в 1913 г., накануне Первой Мировой войны, профессор А.Л.Погодин в «Предисловии» к «Золотой книге сказок» высказал мысль о роли сказок разных народов в жизни людей: «Гремят пушки, все больше вооружаются народы, и, кажется, все их разъединяет, все им вселяет взаимную ненависть и недоверие. Но рядом с этим идет другое течение, еще более, гораздо более сильное: это стремление народов к взаимному познанию, уважение их к духовной жизни другого. <...> Такой интерес воспитывает людей в духе истинной гуманности, и на самое появление нашего сборника на нескольких европейских языках следует смотреть, как на проявление широкого духа гуманности, который в будущем победит и разрушит ненависть и корыстную вражду отдельных народов» (Золотая книга сказок 1913, 13). Примерно через сто лет наш современник написал о сборнике английских сказок на одном из читательских форумов: «... эта книжица привела меня к осознанию, что все люди в мире живут одними и теми же заботами, переживаниями, страстями, стремлением к счастью. Вот только имена героев сказок в книжке - нерусские. А так, все то же самое, что иунас» (25). Как видим, наблюдение профессора А.Погодина оказалось верным: сказки разных народов вот уже больше ста лет помогают воспитывать российскую читательскую аудиторию, открывая ей широкий и добрый мир. 


\title{
РУССКАЯ ЛИТЕРАТУРНАЯ СКАЗКА ЗА РУБЕЖОМ И ЗАРУБЕЖНАЯ СКАЗКА В РОССИИ
}

\author{
(Ева Кудрявцева Маленова)
}

Зарубежная сказка неоднократно сыграла очень важную роль в развитии данного жанра в России. Можно обратить внимание на эпоху немецкого романтизма и сказки братьев Гримм, которые стали «популярными уже во времена Жуковского и Пушкина» (Минералова 2016, 80); из писателей зарубежных литературных сказок необходимо выделить немецкого романтика Вильгельма фон Гауфа (ученика Э. Т. Гофмана) - по мнению И. Г. Минераловой его творчество повлияло на русские сказки Н. П. Вагнера и Л. Чарской. Данный факт бесспорен, однако, помимо выше указанных, одним из важнейших импульсов для русских читателей и писателей стали сказки датского сказочника Ханса Кристиана Андерсена. Особенно плодотворной оказалась для России лирическая основа его сказок. Прямыми или косвенными продолжателями Андерсена можно назвать Н. П. Вагнера, В. М. Гаршина, Л. Чарскую, К. Лукашевича, Е. Л. Шварца, А. Гайдара, В. Бианки, М. Пришвина, К. Паустовского, и с 60-х годов 20 века можно говорить о целом направлении уже сформировавшегося жанрового варианта - т. наз. лирической сказки. Ее развили в своем творчестве, например, Г. Цыферов, С. Козлов, Р. Погодин, Ю. Коваль, Б. Заходер и многие другие.

Однако, вернемся, кпервой трети 20 века изарубежным импульсам в русской литературной сказке. Исследователи обращают внимание на то, что в 20-30-е годы 20 века русская детская литература особо плодотворно наполняется импульсами западных произведений. Отметим лишь три перевода, которые постепенно стали своеобразными вехами в развитии русской литературной сказки. Это «Доктор Дулиттл» Хью Лофтинга, которого К. Чуковский сначала перевел в 1924 году, а затем постепенно перерабатывал в самобытное стихотворное произведение «Доктор Айболит» (1935), мало похожее на прозаический оригинал. Следующим можно упомянуть произведение «Удивительный волшебник из страны Оз» американского писателя Ф. Л. Баума, переведенное А. М. Волковым под названием «Волшебник Изумрудного города» (1939, 2-ая редакция 1962). А. М. Волков по сравнению с К. Чуковским остался намного ближе к англоязычному оригиналу.

В контексте данной монографии обращается особое внимание на итальянские импульсы в развитии русской литературной сказки. Важнейшим из них можно считать произведение К. Коллоди «Приключения Пиноккио. История деревянной куклы», которое перевел на русский язык А. Н. Толстой под названием 
«Золотой ключик, или Приключения Буратино» (1936). Вне нашего внимания оставляем, например, «Три толстяка» (1924) Юрия Олеши. Заметим лишь вкратце, что сюжет связан с неопределенной европейской страной, однако по именам и фамилиям (наследник Тутти и др.) можно догадаться об итальянском прообразе. Тем более, что в основе произведения лежит стилизация итальянской комедии дель арте, перенесенная в сферу циркового искусства (уКоллоди это другая разновидность сценического искусства - кукольный театр). Если шире учесть контекст 20 века, необходимо было бы отметить произведение итальянского сказочника Джанни Родари (неоднократно побывавшего в России) с названием «Приключения Чиполлино» (в русском переводе с 1953 года). Однако это не является задачей данной монографии.

\section{От перевода к переложению и обратно}

\section{(Ева Кудрявцева Маленова)}

Обратим еще раз внимание на перевод. Ключевым явялется то, что упомянутые выше переводы «переводами» в России давно не ощущаются. Это подтверждают два факта - во-первых, то, что на российском книжном рынке сосуществуют переводы (с указанием переводчика в тираже книги и зарубежного автора на обложке) с авторскими обработками-переложениями (как правило, с указанием автора «перевода» на обложке); во-вторых, русские переложения могут переводиться на иностранные языки - чему уделяется внимание вниже приведенных двух главах о польском ичешском контексте (на примере переложения А. Н. Толстого «Золотой ключик, или Приключения Буратино»).

Из сложной ситуации, когда изначальный авторский текст растворяется в оригинальном творческом подходе переводчика-соавтора, вытекают сложности терминологического определения и особенно культивируемое научной сферой стремление избежать плагиаторства - см. название статьи «Является ли «Золотой ключик» плагиатом «Пиноккио»?» (Курий, 2009). Исследователи понимают, что говорить о «переводе» неправильно, так как текст основательно изменился, стал оригинальным, и рассчитан, таким образом, на русского читателя. Поэтому часто употребляются термины: «переложение» (Минералова, 2016, 133), «пересказ» (Арзамасцева-Николаева, 2007, 305), «переделка» (Зубарева, 2004, 305), и появляются новые термины: «перевоссоздание» (Минералова, 2016, 124).

Как уже намекалось, именно в данном контексте периодически возвращается (и особенно в наше время) вопрос по выяснению границ между сугубо авторским 
текстом и скопированным, т. е. плагиатом. Данный вопрос, однако, давно решен, например, в самой эволюции жанра, которому посвящена данная монография ведь, если бы не возникли своего рода «плагиаты», т. е. авторские варианты народных сказок и их последующие переработки, то вряд ли была бы сегодняшняя литературная сказка как жанровый вариант настолько плодотворна и актуальна.

\section{Итальянаский оригинал и русский перевод - Пиноккио и Буратино в польском контексте}

(Паулина Вуйциковска-Вантух)

(под редакцией Марии Ненароковой)

Если попытаться коротко охарактеризовать место книг Приключения Пиноккио История деревянной куклы (1883) Карло Коллоди и Золотой ключик или приключения Буратино (1936) Алексея Толстого в современной польской детской литературе, то, к сожалению, следует сказать, что сказку про Пиноккио знают почти все, а Буратино уже никто не помнит. Еще тридцать лет тому назад ситуация выглядела иначе, русскую детскую литературу читали и издавали, в том числе

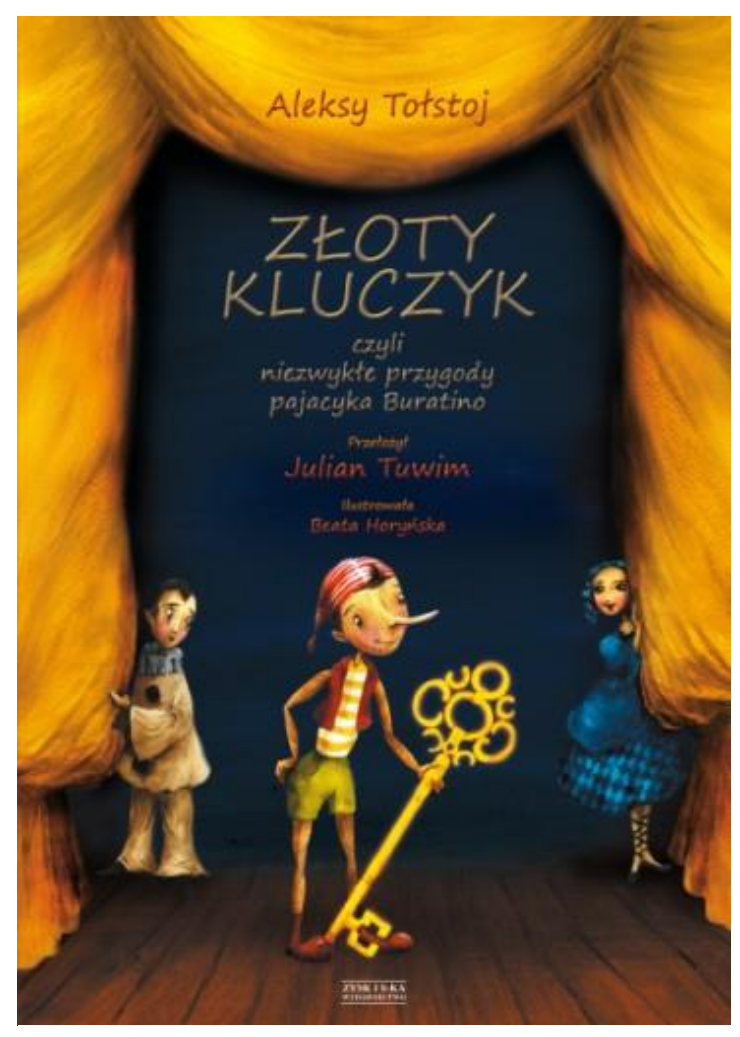

Рисунок 1 - Олбожка издания польского перевода Ю. Тувима и Золотой ключик или приключения Буратино. Все изменилось под влиянием политических перемен в 1989 году, когда в результате переговоров властей Польской Народной Республики ипрофсоюза "Солидарность” был отменен режим ПОРП (Польская Объединенная Рабочая Партия) и Польша перешла к демократии и рыночной экономике. Последовательно в 90-ые годы польская культура отказалась от советского культурного наследия и полностью переориентировалась на западноевропейскую и американскую культуры (А. Вавжинчак 2010, 317; Anna Musioł 2011, 100). Исследовательница Алиция Володзко-Буткевич пишет даже о дискредитации русской литературы 
(Alicja Wołodźko-Butkiewicz 2009, 1-10) в это время. Потом, примерно через десять лет начались размышления о том, что в советское время не все было так плохо. После периода отрицания русскоязычной литературы издатели начали переиздавать русскую классику (Л. Толстой, Ф. Достоевский, А. Чехов, А. Солженицын, М. Булгаков) ипроизведения современных авторов бестселлеров, втом числе книги А. Марининой, Б. Акунина, В. Пелевина, Л. Улицкой, Т. Поляковой (Semczuk 2010, 67-82). Тем не менее, следует отметить, что сегодня издания русской литературы для детей и молодежи на польском языке (за исключением народных сказок) практически отсутствуют, прежде всего из-за экономических причин - они не могут рассчитывать на массового читателя. Как доказывает Дарюш Кардела, в годы 2007-2012 были изданы лишь пять книг в жанре сказки (Kardela 2014, 53). Итак новые переводы и издания русской детской литературы не появляются, кроме того, забытые книги, заполняющие библиотеки, почти никто не читает. Об этом говорят статистические данные, полученные в результете исследования читательского спроса. Например, на протяжении 2007-2012 гг. русская литература для детей составила лишь 0-1 \% всех русскоязычных книг, которые были прочитаны пользователями городской библиотеки во Вроцлаве, где самым большим спросом пользовались детективы, фантастика и мемуары (ibidem, 54).

В связи с этим сопоставление книг Карло Коллоди и Алексея Толстого - тема интересная не только с точки зрения истории возникновения этих книг и места, которое они занимают в детской литературе Польши и России, она привлекательна и потому, что затрагивает важные проблемы восприятия детской литературы. Пример Приключений Буратино показывает, как забывают качественную переводную литературу, которая создавалась в период соцреализма в СССР и в других коммунистических странах (например тексты К. Чуковского, С. Маршака, Э. Успенского, П. Бажова, Ю. Олеши, А. Гайдара, В. Катаева, Б. Сутеева и др.). Этот вопрос оказывается тем более важным, что в последнее время охотно переиздается польская литература этого же периода Польской Народной Республики (1944-1989) в оригинальном художественном оформлении ${ }^{7}$. Издатели ичитатели признают высокой артистический уровень текстов и иллюстраций этих книг. История Пиноккио другая, хотя герой, придуманный Карло Коллоди, еще популярен, эта книга пример того, как произведение входит в канон детского чтения, а потом ее сюжет подвергается процессу постепенной коммерциализации вплоть до полного забвения авторского текста из-за большого числа адаптаций плохого качества.

\footnotetext{
${ }^{7}$ Большой популярностью среди читателей пользуются детские небольшие рассказы из серии Почитай мне мама а также Наши книжечки.
} 
Понятно, что указанные выше вопросы становятся частью общей проблемы восприятия детской книги в современной Польше. Одним из факторов, влияющих на современную ситуацию в детском книгоиздании, являются рыночные и коммерческие отношения на книжном рынке, а также реклама как способ формирования читательских вкусов с самого раннего возраста. С 90-ых годов XX века начались перемены, которые по сравнению с периодом ПНР можно назвать революционными. Раньше книжным рынком управляли центральные государственные органы, а немногочисленные издательства принадлежали государству (детские книги с 1921 издавались в издательствах Nasza Księgarnia, Krajowa Agencja Wydawnicza, Biuro Wydawnicze Ruch, Czytelnik, Iskry), все тексты подвергались цензуре и должны были отражать культурную политику государства. В связи с этим большими тиражами издавались в основном русскоязычные книги. Как отмечает Малгожата Семчук, в 1945-1989 годы суммарный тираж изданий русских книг достиг 110 млн экземпляров (Semczuk 2005, 18). После 1989 года в детской литературе восновном доминировала книжная продукция из США, издававшаяся по лицензии крупных концернов. Заметное оживление всреде писателей, издателей, художников, заинтересованных в создании продукции для детей, наступило в начале XXI века. Вчисле причин мощного развития детской литературы в Польше в начале нового тысячелетия авторы издания Национальной Библиотеки Ruch wydawniczy w liczbach 2016 указывают на глобальный успех книги о Гарри Поттере, который повлиял на возрождение жанра литературной сказки, а также стремление польских издателей показать национальную продукцию на Ярмарке Детской книги в Болонье. В это время начинает свою деятельность фонд, продвигающий издание детской литературы - Fundacja ABC XXI, начавший акцию „Cała Polska czyta dzieciom”/„Вся Польша читает детям” (Ruch wydawniczy w liczbach 2016, 34-35). На рынке появляются небольшие, узко-ориентированные издательства, которые издают книги польских и зарубежных авторов для малышей, детей и молодежи, в первую очередь заботясь о хорошем качестве издания, перевода и иллюстраций (Muchomor, Adamada, Zakamarki, Kultura Gniewu, EneBueRabe, Dwie siostry, Татарак идругие). Эти „карликовые издательства”, как определила их журналист газеты „Gazeta Wyborcza”, часто издают маленькими тиражами книги, поднимающие трудные или спорные темы (Maciejewicz 2010, online), но качество

\footnotetext{
8 Издательство было основано в 1921 году Союзом Учителей Польши и действует до сих пор. Издательство доминировало на рынке детской книги с 1946 по 1989 год (1852 заглавия, вторая по очереди Krajowa Agencja Wydawnicza - 216 заглавий, Elżbieta Jamróz Stolarska 2014, 49), сотрудничало со знаменитыми польскими авторами детской литетратуры (Л. Керн, Я. Бжехва, Х. Бехлер, В. Хотомска, Э. Низюрски и другие).

http://www.sbp.pl/wydawnictwa/archiwum_cyfrowe/pdf/?book_id=2318.
} 
издания всегда высоко. Это позволяет их книжной продукции конкурировать с крупными издательскими концернами (Foksal, Egmont), большими и средними издательствами (Nasza Księgarnia, Znak, Zielona Sowa, Olejesiuk, Wilga, Bajka).

Статистика подтверждает, что количество изданий для детей постоянно растет (см. таблица ниже). В 2015 году вместе детская и молодежная литература составляли $26 \%$ всей литературной продукции в Польше (соответсвенно 22\% детская литература и 4\% молодежная литература), при этом научная и профессиональная литература по предмету не учитываются.

\begin{tabular}{|c|c|}
\hline Год & $\begin{array}{c}\text { Количество новых изданий } \\
\text { (заглавий) для детей и молодежи }\end{array}$ \\
\hline 1950 & 324 \\
\hline 1989 & 437 \\
\hline 2005 & 1056 \\
\hline $2006-2014$ & 1079 \\
\hline 2015 & 2144 \\
\hline
\end{tabular}

Таблий 1 - Ruch wydawniczy w liczbach 2005, 2015; Jamróz-Stolarska 2014, s. 30-32

Среди переводной литературы наибольшую часть составляют переводы с английского (475), французского (318) и немецкого (195) языков. В Польше постоянной популярностью пользуются также детские книги скандинавских авторов. Важно отметить, что вчисле изданий, относящихся кдетской имолодежной литературе, в 2015 году на польский была переведена лишь одна книга с русского языка, 57 книг с итальянского, 3 с чешского (Ruch wydawniczy w liczbach 2016, 88).

О том, что рынок детской книги в Польше стремительно развивается, помимо растущего количества новых заглавий свидетельствует высокая посещаемость выставок детской книги в Познани, Варшаве и Вроцлаве, большое количество блогов и сайтов посвященных обзорам и рецензиям книг для детей и юношества ${ }^{9}$, профессиональные журналы („Ryms”, „Filoteknos”, „Czy tam, czy tu”) и, наконец, литературные премии: Книга Года Польской Секции IBBY, „Przecinek i Kropka” премия сети Empik, премия имени Корнеля Макушинского, Премия Зеленого Гуся (Laskowska 2017, 207-209). К сожалению, участь русскоязычной переводной литературы в рынке детской книги совсем незавидна.

\footnotetext{
${ }^{9}$ я привожу лишь некоторые адреса сайтов: https://www.strefapsotnika.pl/tag/blog-o-ksiazkach-dladzieci/; http://znak-zorro-zo.blogspot.com; http://www.malekruki.com; http://www.lupuslibri.pl; http://www.makiwgiverny.pl [дата обращения 20.12.2018].
} 


\section{Восприятие книги Пиноккио в Польше}

Карло Коллоди постоянно занимает высокое место среди самых издаваемых в Польше писателей. Он известен в Польше как автор одной книги про приключения деревянной марионетки. До 2015 года книга Пиноккио выдержала 75 изданий (Ruch wydawniczy w liczbach 2016, 153). Наиболее часто ее издавали в 1986-95 (13), 1996-2005 (27) и 2006-2014 (18) гг. Оригинальный текст Коллоди переводился 12 раз, однако следует отметить, что текст существует в многочисленных адаптациях

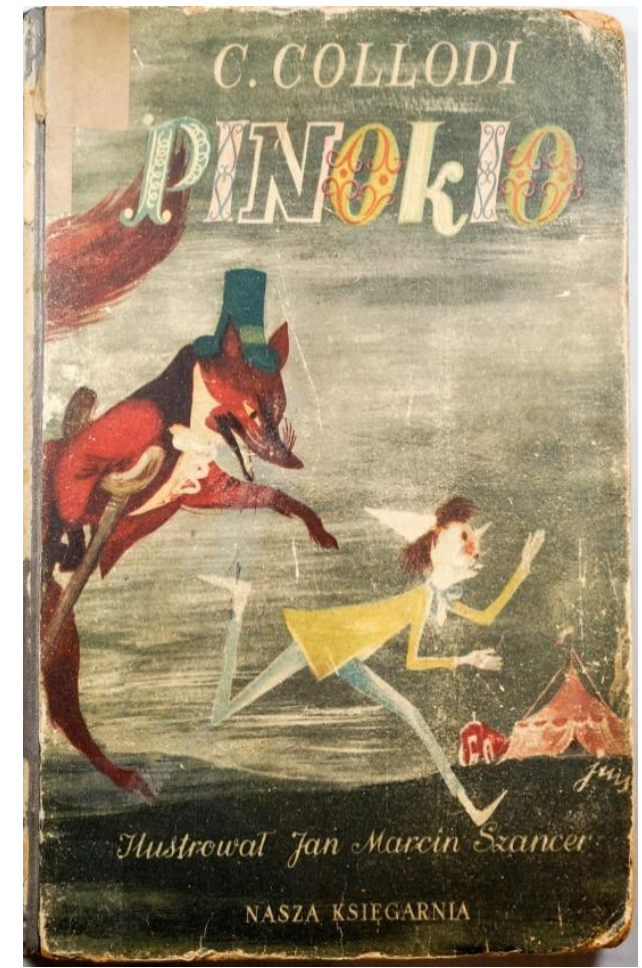

Рисунок 2 - Пиноккио в переводе Зофии Яхимецкой с иллюстрациями Марцина Шанцера «Nasza Księgarnia» (1954). и пересказах, которые не всегда отличаются хорошим качеством и подчас имеют мало общего с оригинальным текстом. Большая часть этой низкокачественной продукции написана по мотивам книги Коллоди и предназначена для самого маленького читателя.

Первый полный перевод книги Карло Коллоди вышел в Польше в 1912 году в издательстве „Gebether i Wolff” под названием Przygody pajaca. Что интересно, на титульном листе мы находим не фамилию Коллоди, а другого итальянского писателя Евгения Херубини, переводчик не указан. Второй перевод книги принес ей известность. Его автором стал Юзеф Виттлин. Книга вышла в 1926 году в издательстве „Biblioteka Groszowa" под заглавием Pinokio: przygody drewnianej kukiełki. Переводчик был настолько увлечен книгой, что во вступлении к изданию предсказал ее будущее:

Приключения деревянной марионетки - это великий фильм в прозе, пленка которого, длиной в несколько метров, представляет собой быстро сменяющиеся необычайно удивительные приключения. Даже если какой-нибудь кинорежиссер попытается экранизировать Пиноккио, книга не потеряет своего обаяния, будущие поколения будут читать ее на одном дыхании [...] (M. Woźniak, K. Biernacka-Licznar, B. Staniów 2014, 161) ${ }^{10}$.

\footnotetext{
${ }^{10}$ Перевод - Паулина Вуйциковска-Вантух.
} 
Перевод Виттлина имел несколько переизданий в 40-ые годы (1946, 1948, 1950). Моника Возьняк замечает, что в это время Пиноккио стал героем коллективного воображения так же, как Золушка, Красная Шапочка идр. Как известно, книга Коллоди вдохновляла многих писателей, в том числе и польских. Известнейшей польской книгой, написанной по мотивам Пиноккио, является Kichuś majstra Lepigliny (1924), автором которой является Янина Поразиньска (1882-1971) ${ }^{11}$. Что интересно, герой книги Поразиньской создан своим папой из глины илишен характерных для Пиноккио черт трикстера - Кихусь с самого начала добрый и милосердный. Действие сюжета проходит в Кракове во времена Средневековья. Писательнице удалось передать местный краковский колорит и поместить в тексте массу познавательной информации по истории и культуре Польши (Z. Białek 1979, 100-101).

Самым популярным переводом книги о Пиноккио считается перевод Зофии Яхимецкой с уникальными картинками польского художника Яна Марцина Шанцера. Книга была выпущена издательством „Nasza Księgarnia”. Перевод стал классическим, до 1994 года было предпринято около 12 переизданий, эта книга переиздается до сих пор, хотя язык перевода можно уже считать устаревшим. В 1994 в издательстве „Siedmiogród” книга Карло Коллоди вышла в переводе Кристины и Евгения Кабатц, потом ее переводили еще Агнешка Пётровска, Галина Козёл, Агнешка Рулыковыска, Патриция Яблоньска, Ярослав Миколаевский и другие. Стоит отметить, что в 90-ые годы XX века появилось наибольше число переводов и адаптаций книги итальянского автора.

\footnotetext{
${ }^{11}$ Одна из самых знаменитых писательниц детской литературы. Автор более чем 30-ти произведений, переводчик с шведского языка, любительница польского фольклора, лауреат литературных премий: Премия Союза писателей Польши (1950), Командорский крест ордена Возрождения Польши (1966), Орден Улыбки (1969).
} 


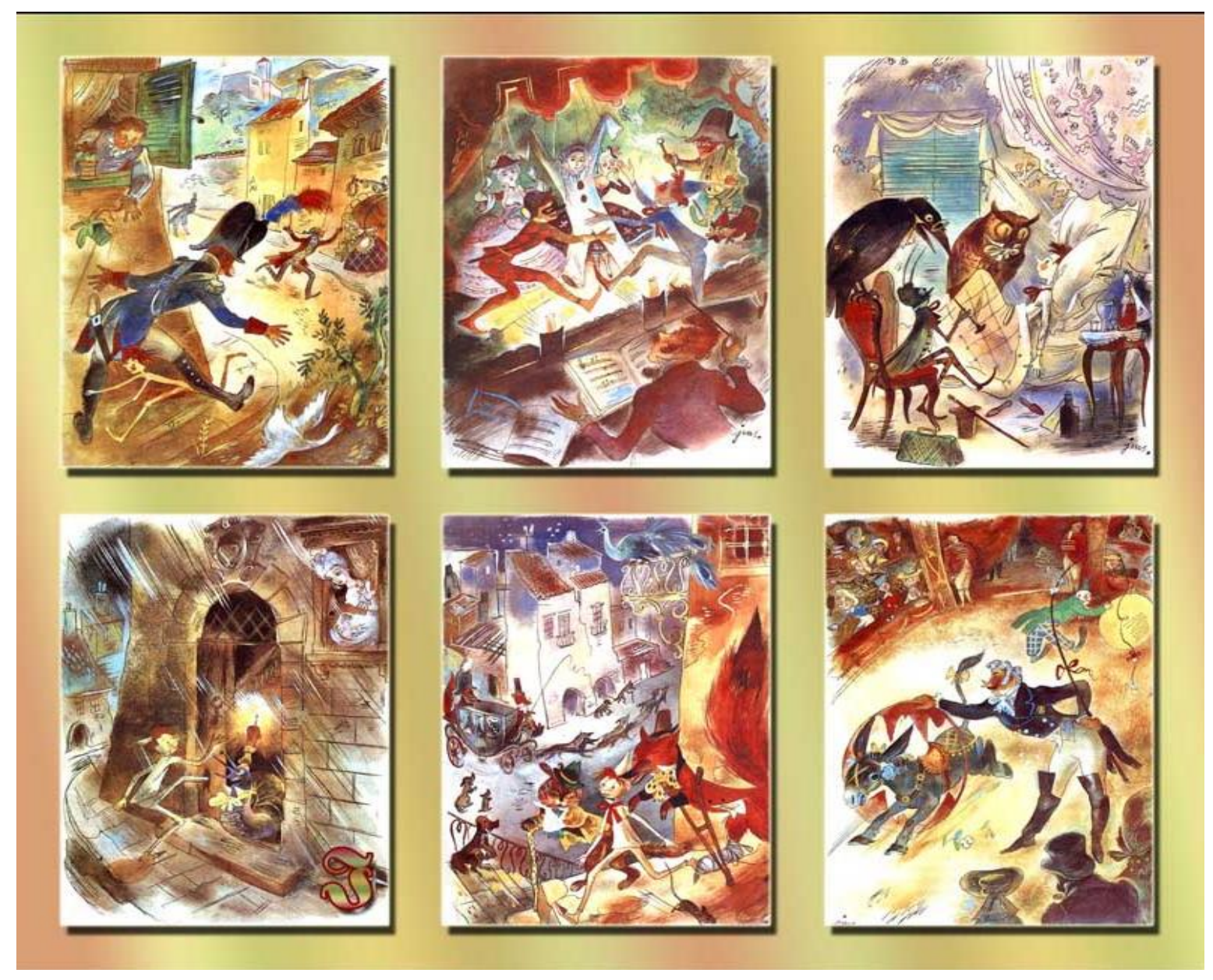

Рисунок 3 - Иллюстрачии Мариина Шанцера к книге "Пиноккио" в переводе Зофии Яхимецкой (https://jarmila09.wordpress.com/2011/11/14/pinokio/) [дата обращчения 20.12.2018].

Особого внимания заслуживает последний из указанных переводчиков Ярослав Миколаевский. Его перевод книги Коллоди 2011 года активно обсуждался в прессе. Книга вышла в издательстве „Media Rodzina” в большом, альбомном формате, в твердой обложке с прекрасными иллюстрациями итальянского художника Роберто Инноченти ${ }^{12}$. В газетах и журналах публиковались восторженные рецензии, и их авторы указывали на удачную попытку переводчика осовременить язык сказки и передать атмосферу Тосканы (Olech 2011, онлайн). Сам переводчик в эпилоге утверждает, что книга многослойная идо сих пор актуальная, в приключениях деревянной марионетки отразилась нелегкая жизнь самого Карла Коллоди - жизненные ошибки инеудачи, борьба со слабостями и сложные

\footnotetext{
${ }^{12}$ Итальянский иллюстратор стал лауреатом многих премий. В 2008 он получил Медаль Ганса Христиана Андерсена (2008). "Нью-Йорк Таймс» назвал Инноченти одним из величайших в мире художников-иллюстраторов детских книг а его иллюстрации кПиноккио самым красивым изданием, какое только видел мир (Humphrey Carpenter 1988, online).
} 
отношения с женщинами. По мнению Миколаевского, книга о Пиноккио продолжает лучшие традиции итальянской литературы, так как она создавалась на родине

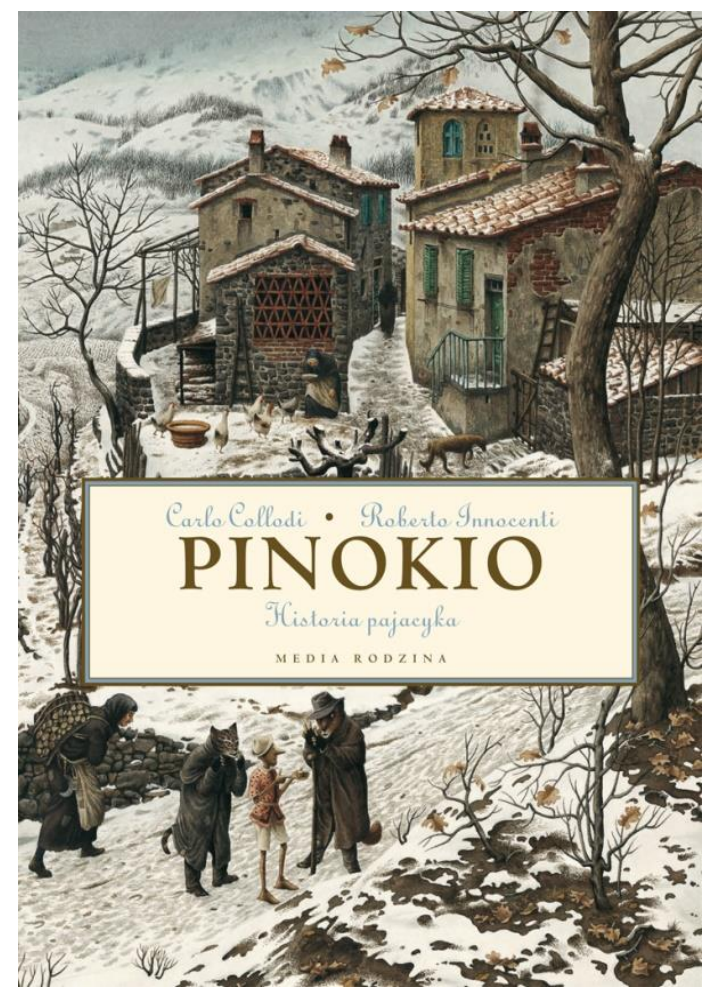

Рисунок 4 - Обложка книги в переводе Я. Миколаевского с иллюстрациями

P. Инноченти, "Media Rodzina" 2011 год. Петрарки, Данте и Боккаччо (Mikołajewski 2011, 201-203).

Всемирный успех Пиноккио очевидно связан с исключительностью героя, так похожего на каждого ребенка. По своей натуре трикстер, Пиноккио не идеален ипоэтому он так близок человеческой натуре. С другой стороны, вовсе не новость, что героем детской сказки становится кукла, игрушка или зверек. Польский исследователь Зигизмунд Бялек дал этому типу литературного героя определение "субдетский": в образах таких героев отражается способ понимания и восприятия мира, присущий ребенку (Białek 1979, 50), подобные персонажи встречаются в литературе очень часто. Кроме образа героя повесть привлекает читателя эстетикой сериала, авантюрностью сюжета, переполненного неожиданными поворотами действия. Кроме того, история Пиноккио имеет счастливый конец, подобно народным волшебным сказкам, и благодаря этому выполняет компенсационную функцию. Польская исследовательница детской литературы Ванда Кжеминьска обращает внимание именно на фольклорный характер Пиноккио, о чем, по ее мнению, свидетельствует близость к народным бытовым сказкам, элементы абсурда и смесь реального с фантастикой (Wanda Krzemińska 1963, 106-107).

В Польше, видимо, как и вдругих странах, «Пиноккио» стал книгой, связывающей поколения и благодаря своему продолжительному присутствию в круге детского чтения. Этому способствовали экранизации, особенно Пиноккио, снятый в студии Уолта Диснея (фильм стал очень популярен в Польше в 90-ые годы). Иоанна Олех пишет в одной из рецензий, что: «мультфильм Диснея повлиял на книгу Коллоди, как омолаживающее лекарство. С другой стороны, в связи с продолжительным существованием книги, в ней стали сглаживать углы и лишать ее 


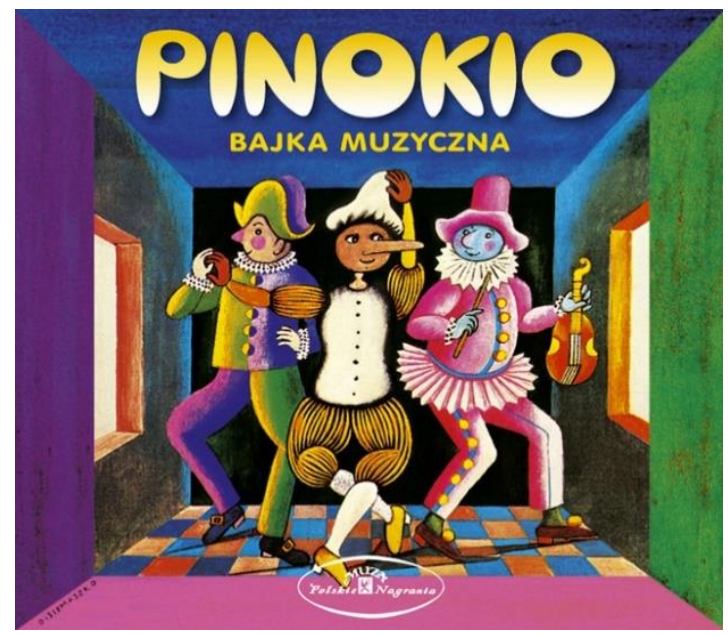

Рисунок 5 Рисунок - Обложка диска с польской аудиозаписью сказки Пиноккио. Текст Зофия Яхимеика по мотивам сказки Карло Коллоди, музыка Рушард Селиики, MUZA (1976). горечи и ужаса» (Olech 2011, online). Благодаря многочисленным театральным постановкам книга стала частью культуры, спектакли по мотивам Коллоди ставят охотно вплоть до сего дня во многих театрах Польши - не только кукольных. В 1932 году во Львове состоялась премьера первого польского спектакля по мотивам книги Коллоди в постановке Бронислава Домбровского, в 1946 году сказку ставили в детском театре «Wesoła Gromadka» в Кракове (режиссер Мария Билижанка). «Онлайн-энциклопедия польского театра» насчитывает больше

100 постановок, в основу которых была положена сказка Карло Коллоди. Стоит еще упомянуть, что ее можно было слушать и по радио, а в 1978 году была создана знаменитая музыкальная сказка Пиноккио, текст которой написала переводчица книги - Зофя Яхимецка, великолепную музыку сочинил композитор - Рышард Селицки.

Нет сомнений, что на успех книги и ее бытование в коллективном воображении заметно повлияла культурная политика государства. Пиноккио с 1959 года находился в списке книг, которые рекомендовались для чтения в школе (Jędrych 2014, 205). В 2008 году книга Коллоди официально была помещена в список обязательного чтения для четвертого класса начальной школы и оставалась в нем вплоть до 2014 года. Однако, согласно последнему распоряжению Министерства Образования (2018 год) Пиноккио бвл исключен из списка, хотя по словам сотрудницы городской детской библиотеки в Тарнуве ${ }^{13}$, некоторые учителя все еще продолжают работать с этой книгой во время уроков. В 2002 году Пиноккио вписали в канон Книг для Детей и Молодежи, составленный газетой „Gazeta Wyborcza”, и объявили одной из 50-ти книг, которые должны находиться в детской библиотеке (Woźniak, Biernacka-Licznar, Staniów 2014, 244).

Рассуждая на тему Пиноккио как текста культуры, стоит упомянуть что, в Польше особенно популярен мотив удлиняющегося носа Пиноккио. Иногда про человека, который открыто врет, говорят, что у него «растет нос как у Пиноккио».

\footnotetext{
${ }^{13}$ Город средний по величине, насчитывает около 100000 жителей.
} 
Несмотря на культурные ассоциации, которые вызывает этот мотив (в свое время внимание людей привлек рекламный ролик средства для усиления потенции), книга прежде всего считается притчей, поучительной сказкой, утверждающей христианские жизненные идеи. Кстати, в 2009 году на польский язык была переведена книга Алессандро Гноччи и Марио Пальмаро Пиноккио не только сказка.

Другое дело - это восприятие книги о Пиноккио современным детским читателем. Большинство детей в возрасте семи лет Пиноккио знают, но в адаптациях и пересказах, или же смотрели фильм. Оригинальный текст для них слишком труднен и длинен (Woźniak, Biernacka-Licznar, Staniów 2014, 30). С другой стороны, старшеклассники считают книгу совсем детской и оценивают ее не очень высоко, указывая на нереальность описанных в книге событий (Krasińska 2006, 579). Это показывает, как меняются вкусы и ожидания молодых читателей подросткового возраста. Фонд Fundacja ABC XXI, о котором я упоминала выше, создал „Золотой список" книг для детей согласно их возрасту ${ }^{14}$. Пиноккио Карло Коллоди поместили среди книг для детей в возрасте 4-6 лет (sic!) вместе со сказками Андерсена, Винни Пухом Алана Милна и Пеппи Длинныйчулок Астрид Линдгрен. Парадокс в том, что полный текст Пиноккио для детей дошкольного возраста, потенциального адресата книги, недоступен - для них он слишком длинный и сложный, хотя, как кажется, дети вполне способны отождествлять себя с героем книги. Поэтому адаптации Пиноккио оказываются столь популярны.

Место книги Карло Коллоди в польской детской литературе уже не изменится, она вошла в канон, стала классикой и скорее всего всегда найдет своего читателя, как и книги Алана Милна и Астрид Линдгрен. С другой стороны, нельзя забывать, что в последние годы рынок детской книги заметно расширился и предлагает читателю замечательные новые книги и издания, поэтому вряд ли Пиноккио вновь удастся привлечь массовую публику.

\section{Золотой ключик или приключения Буратино в польском контексте}

Мирон Петровский в работе Книги нашего детства пишет, что «можно искренне пожалеть каждого, кому не посчастливилось в детстве прочесть Золотой ключик» (Петровский 2010, 219). Исследователь в главе Что отпирает «золотой ключик»? подробно описывает обстоятельства возникновения книги Алексея Толстого

\footnotetext{
${ }^{14}$ Список можно посмотреть онлайн:

http://www.calapolskaczytadzieciom.pl/ckfinder_pliki/files/zlota_lista/Zlota_Lista_\%2B_lista_dla_rodzic ow_WRZESIEN2018.pdf [дата обращения 20.12.2018].
} 
и раскрывает все тайны, связанные с ее истолкованием. Оказывается, что культовая в России книга содержит намного больше значений, чем обыкновенная книга для детей. Она задумана Толстым как двухадресное произведение, ведь в рукописи к книге был добавлен подзаголовок «новый роман для детей и взрослых» (ibidem, 220). Чтобы раскрыть все тайны этой книги, нужно много знать как об эпохе модернизма и литературе этого времени, так и о самом авторе, которому пришлось жить в то время.

Исследователь Марк Липовецкий замечает, что вокруг сказки Толстого в советское время образовалась обильная субкультура ${ }^{15}$. Золотому ключику присущи многослойность и глубина, которые «позволили деревянной кукле стать архетипом, оформившим какие-то важнейшие элементы культурного бессознательного, открытым для многочисленных творческих интерпретаций и в то же время сохраняющим свои неповторимые и узнаваемые черты, подобно таким (немногим) архетипам советской культуры, как Сталин иЛенин, Чапаев или Штирлиц». (Липовецкий 2003, online).

Если не вдаваться в подробности,то можно сказать, что главным различием между книгой про Пиноккио (1826-1890) и Буратино (1935) является культурная и историческая ситуация, в контексте которой возникли эти книги. Сказка итальянского писателя является примером детской литературы XIX века, она написана в духе педагогики этого периода и сосредоточивается на воспитании читателя-ребенка. На первое место выходит мораль, последняя сцена, в которой кукла окончательно превращается в мальчика, награда, которую получает герой в результате своего нравственного роста. Эта сцена отсутствует в Золотом ключике, где кукла остается куклой, но побеждает врагов, раскрывает тайну золотого ключика и достигает счастья. Книга Толстого была написана на полвека позже и кроме сюжетной линии содержит элементы, характерные для модернистской литературы - символы, цитаты, намеки. Время создания является исходной точкой для всех дальнейших рассуждений ${ }^{16}$. Факты таковы, что с момента публикации книга Толстого полностью вытеснила Пиноккио с читательского рынка СССР.

В польском контексте, к сожалению, нет оснований рассматривать Золотой ключик как культовую книгу. Даже наоборот - она скорее всего принадлежит к забытым шедеврам советской литературы. К тому же, проблема восприятия

\footnotetext{
${ }^{15}$ Автор указывает на определенные составляющие этой субкультуры: театральные постановки, фильмы, песни городского и детского фольклора, конфеты, вафли, лимонад, игрушки, маски, магазины, настольные и напольные игры, репертуар эротических анекдотов и т. д. (Липовецкий 2003, online).

${ }^{16} \mathrm{O}$ различиях между итальянским оригиналом и его русской адаптацией речь пошла в предыдущих разделах.
} 
Приключений Буратино в Польше вообще не затронута. Нет научных статьей, разрабатывающих эту тему, существуют лишь немногочисленные упоминания в работах, посвященных детской литературе в Польше (Wortman 1958, Białek 1979).

Во времена тесного сотрудничества ПНР и СССР книги русских писателей издавали и читали, в том числе и эту сказку Алексея Толстого. Культурная политика «обеспечивала» читателей как детской, так ивзрослой профессионально написанной литературой. Эта литература была написана в соответствии с законами соцреализма в искусстве ипринципами перевоспитания общества в духе диалектического материализма. Как отмечает Билински, за время ПНР в среднем в Польше издавали 285 новых книг в год, общий тираж которых составлял около 15 миллионов экземпляров, тираж одного заглавия в среднем превышал 50 тысяч экземпляров (Biliński 1977, 106). Литература для детей выполняла важнейшую роль в воспитании молодых поколений в духе советской идеологии - после пленарного съезда партии в 1947 и 1949 годах приоритетом стала социальная проблематика, даже в фантастических и сказочных жанрах. Однако, кроме откровенно пропагандистских текстов, появлялись книги, которые учили детей нравственности, описывали проблемы в семье, в школе и среди друзей (Maria Ostasz 1999, 54-59). Настоящей популярностью среди молодежи пользовалась например книга Гайдара Tимур и его команда (13 польских изданий), несмотря на ее полное согласие с действующей идеологией. Халина Вятрова пишет, что тираж книг Гайдара изданных в Польше превысил 1,3 миллионов экземпляров (Н. Wiatrowa 1973, 24). В своей статье исследовательница также перечисляет известных в Польше советских авторов детской книги, в первую очередь это Корней Чуковский и Алексей Толстой.

С творчеством Алексея Толстого польские читатели могли познакомиться в 20ые годы XX века. В 1927 году в Варшаве в издательстве «Rój» была издана антология рассказов современных русских писателей под заглавием Ludzie jaskiniowi в переводе Мечислава Бинома. Рассказ Алексея Толстого Cuchnqcy diabet (Тухлый дьявол) был помещен в сборнике рядом с текстами Михаила Зощенко, Евгения Замятина, Ивана Бунина, Бориса Пильняка идругих. Годом позже в очередной антологии под заглавием Z motykq na słońce, выпущенной в этом же издательстве и тоже в переводе Бинома, были помещены рассказы на тему «литература и революция». На этот раз текст Толстого Rękopis znaleziony pod łóżkiem (Рукопись найденная под кроватью) оказался среди рассказов Пантелеймона Романова, Алексея Бибика, Валентина Катаева, Сергея Заяицкого и Исаака Бабеля. В 1935 году в переводе Алиции и Анатоля Стернов вышел фантастический роман Толстого Гиперболоид инженера Гарина под польским заглавием Eksperyment inż. Garina. Интересно, что известнейший фантастический роман 30-тых годов - Аэлита - 
в Польше был издан лишь в 1956 году (перевод - Алиция Стернова). В 30-ые годы читатели могли ознакомиться и с другими произведениями писателя. В 1934 году, когда в СССР был опубликован исторический роман Петр Первый ${ }^{17}$, в варшавском

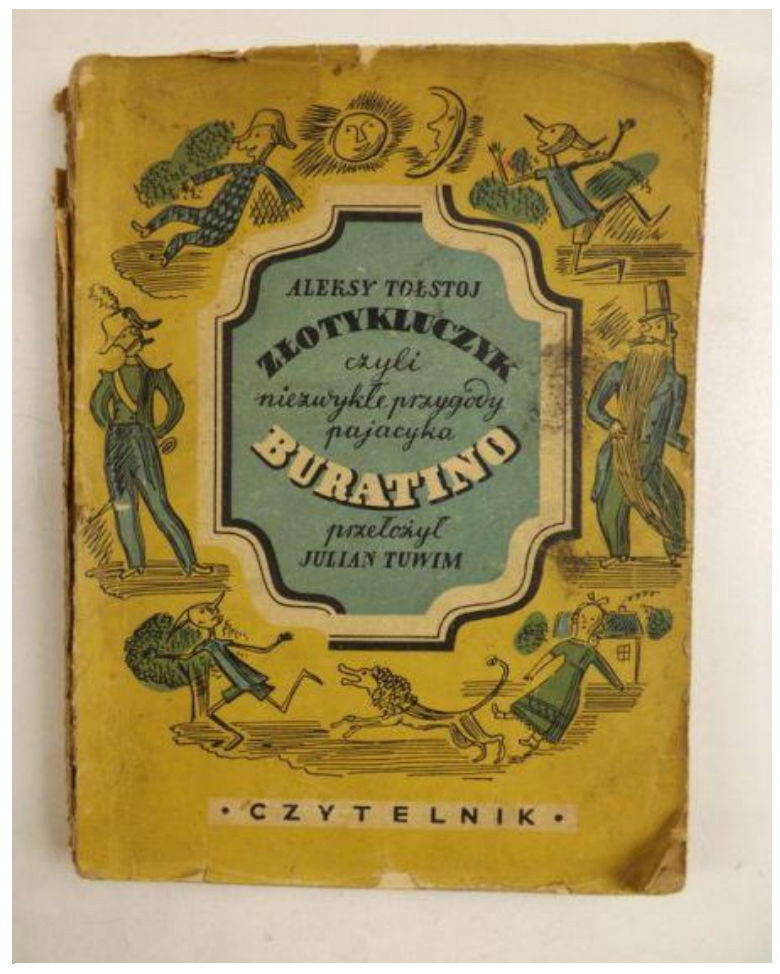

Рисунок 6-Обложка книги «Złoty kluczyk czyli niezwykte przygody Buratino» Алексея Толстого в переводе Ю. Тувима, Czytelnik (1949). издательстве Яна Пжеворского вышли сразу два тома в авторском переводе Андрея Ставара. В послевоенное, неспокойное время, когда в Польше укреплялась коммунистическая власть, в издательстве «Czytelnik» были изданы два тома трилогии Хождение по мукам (Droga przez mękę): Siostry (1946) и Rok osiemnasty (1946) в переводе знаменитого польского поэта и писателя - Владислава Броневского. Третий том - Pochmurny poranek вышел в 1949 году. Трилогия Толстого многократно переиздавалась (15 изданий) и является до сих пор самым популярным и узнаваемым произведением этого писателя

в Польше. Издатели не обошли вниманием и малой прозы писателя. Издавались как новеллы, так и рассказы Толстого, среди них Chleb: obrona Carycyna (5 изданий), антология рассказов Błękitne miasta (2 издания), антология новелл Żmija.

В 1949 году снова в издательстве «Czytelnik» тиражом 10.000 тысяч экземпляров вышло первое издание Приключений Буратино. Книгу под польским заглавием Złoty kluczyk. Niezwykłe przygody pajacyka Buratino перевел знаменитый польский поэт Юлиан Тувим. Год позже издательство издало автобиографическую новеллу для детей Dzieciństwo Nikity (Детство Никиты). Кстати, Станислав Фрыче, автор работы Literatura dla dzieci i młodzieży w latach 1945-1970 замечает, что в начале 50-ых годов в Польше не хватало польской продукции для юного читателя, отвечающей идеологическим переменам в стране. Количество переводной литературы в это время составляло более, чем 50\% продукции для детей и молодежи, число книг постоянно росло (1950 - 56,7\%, 1951 - 59,6\%, 1954 -

\footnotetext{
${ }^{17}$ Всего этот романChyba! Záložka není definována. издавался десять раз, последний в 1986 году.
} 
41,7\%, 1956 - 26,4\%, Frycie 1983, 228-239). Самую большую часть продукции иностранной переводной литературы составляли тексты советских писателей (Россия и другие республики СССР) ${ }^{18}$. После 1956 года ситуация немного изменилась, и издательства начали интенсивно издавать книги западных классиков (ibidem 237-256).

Вернемся к переводам А.Толстого. Младшие читатели могли познакомиться со сказками писателя, а точнее с его адаптациями русских фольклорных сказок собранных в антологии Baśnie, bajki, bajeczki: ludowe bajki rosyjskie. Сказки умело перевела сестра Юлиана Тувима - Ирена Тувим, и вышли они в детском издательстве «Nasza Księgarnia» в 1969 году (4 переиздания) с красивыми иллюстрациями Юлиюша Маковского. Перевод Ирены Тувим отличается легкостью и юмором. В 70-ые и 80-ые годы издатели восновном переиздавали уже существующую на читательском рынке продукцию Алексея Толстого. Не углубляясь в детали, следует сделать вывод, что Алексей Толстой принадлежит кгруппе довольно часто издаваемых зарубежных писателей. Электронный каталог NUKAT, в которым собрана информация из всех библиотек в Польше, насчитывает в общем 118 публикаций этого автора на польском языке. Зато, по данным профессионального издания Ruch wydawniczy w liczbach za rok 2016 число всех изданных в Польше книг Алексея Толстого начиная с 1944 года составляет $68^{19}$. Статистика однозначно показывает, что наибольшее число книг писателя было издано в 50-ые годы, потом число изданий постепенно снижается (1986-1994 гг. 2 издания, 1995-2005 гг. - 0, 2006 г. -2015 г. - 3, 2016 г. - 0).

\section{Польские издания сказки Алексея Толстого}

Всего а Польше вышло 9 изданий Приключений Буратино в переводе Юлиана Тувима. Первое издание 1949 года появилось в издательстве «Czytelnik». Стоит упомянуть, что книга вышла в художественном оформлении советского художника польского происхождения - Бронислава Малаховского, который был лично знаком с Алексеем Толстым иявлялся автором иллюстраций кпервому изданию Приключений Буратино в СССР (Детгиз, 1936). По данным издательства «Czytelnik», второе издание (1951 год) вышло стандартным тиражом 10.000 экземпляров, а третье (1952 год) увеличенным 20.000 экз.

\footnotetext{
${ }^{18}$ Самые популярные детские произведения, изданные в Польше в 50-тые гг.: Pawlik Morozow Виталия Губарева, Szwambrania Льва Кассиля, книги Николая Носова, Opowiadania o Leninie Александра Кононова, Dziesiq̨a planeta Беляева и Odkrywcy Arktyki Георгия Кублицкого (Frycie 1983, 228-239).

${ }^{19}$ Сравним: книги Льва Толстого были изданы в Польше 140 раз, Ивана Тургенева 71, Николая Гоголя 61, Пушкин 122 раза (Ruch wydawniczy w liczbach 2016, 111).
} 

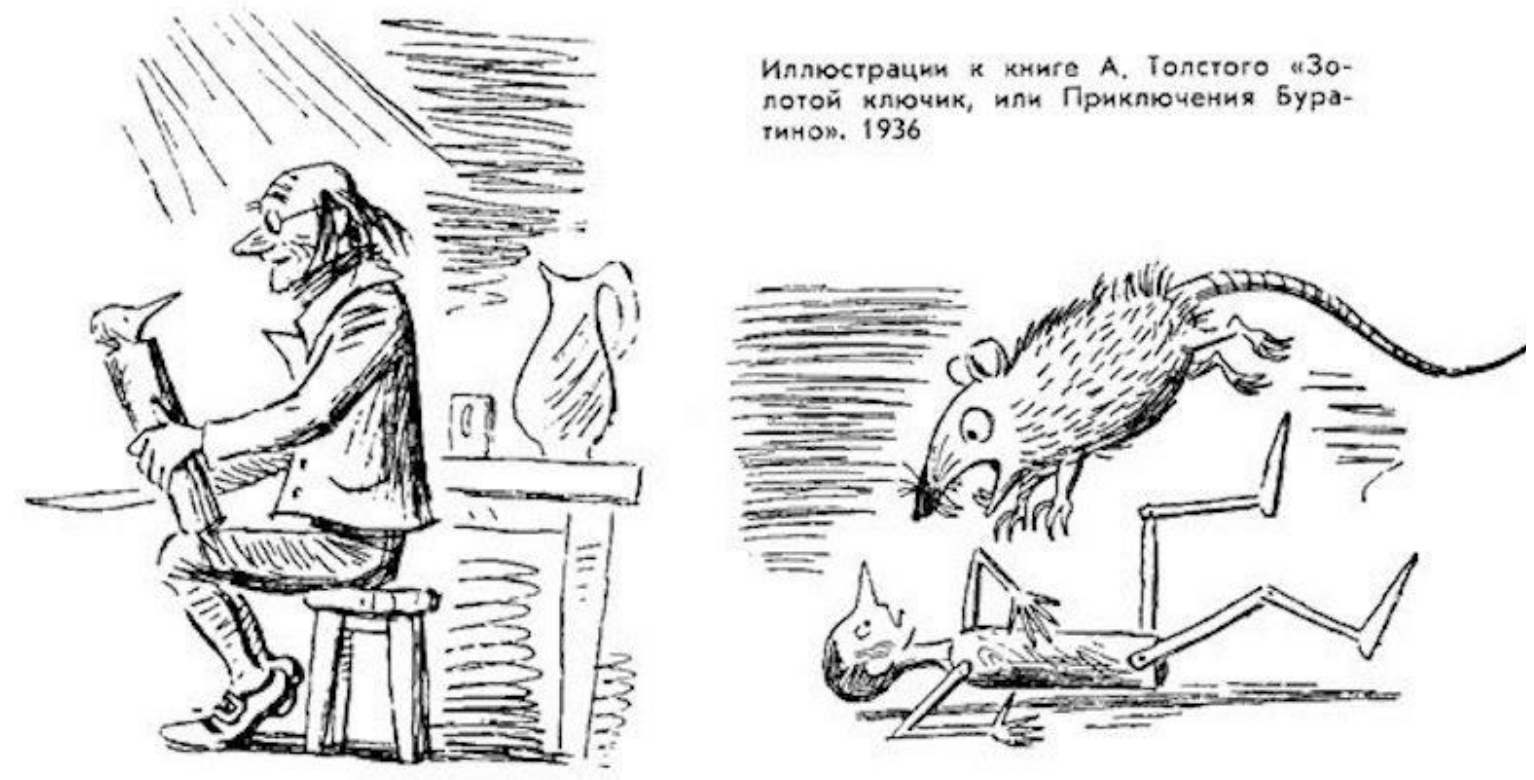

Рисунок 7 -Источник иллюстращии: https://golos.io/ru--istoriya/@ramin/istoriyaillyustracii-bronislav-malakhovskii-zolotoi-klyuchik-ili-priklyucheniya-buratino [дата обращения 20.12.2018]

Четвертый раз (1953 год) книга вышла уже в детском издательстве «Nasza księgarnia» (тираж 30.000) с иллюстрациями Збигнева Рыхлицкого.

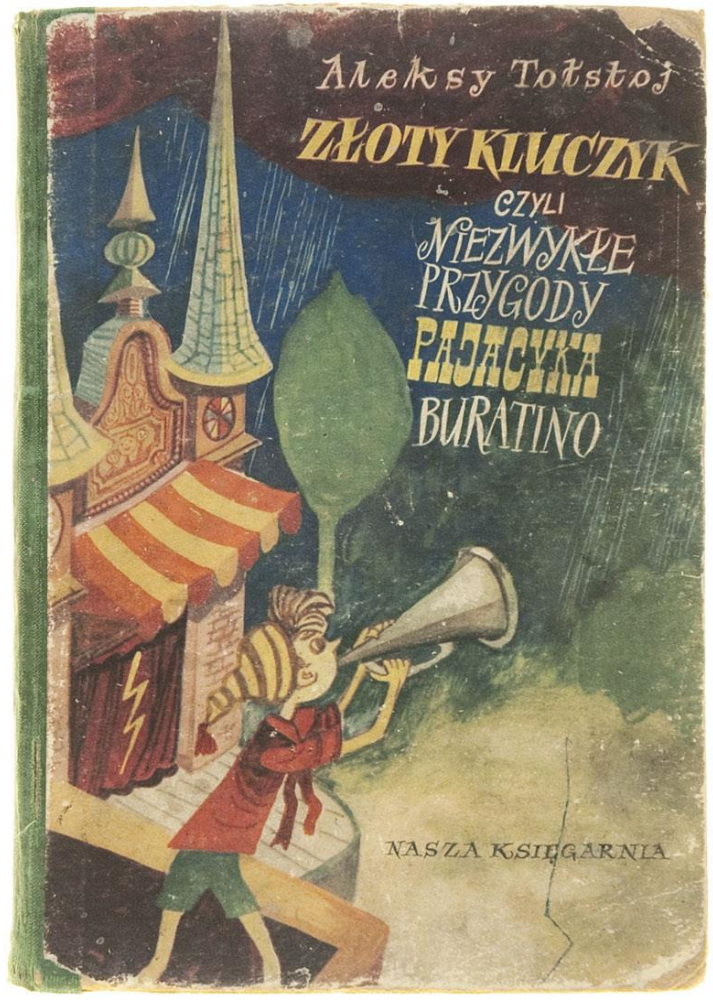

Рисунок 8 - Обложка книги «Złoty kluczyk czyli niezwykte przygody Buratino» Алексея Толстого в переводе Ю. Тувима, Czytelnik (1953).

Следующих польских изданий Приключений Буратино пришлось ждать тридцать лет. В 1983 году московское издательство «Радуга» переиздало книгу с иллюстрациями Алексея Каневского (впервые книга Алексея Толстого с этими рисунками была выпущена в 1950 году в (CСР), а пять лет спустя в сотрудничестве с варшавским издательством «Współpraca» в художественном оформлении Александра Кошкина (1988, тираж 100.000 экземпляров). Стоит подчеркнуть, что с этими изданиями хорошо знаком и русский читатель. 
Далее издания сказки Алексея Толстого были выпущены уже после политических изменений 1989 года. В 1992 году в варшавском издательстве «Votum» в рамках серии Niezapomniane ksiq̨żki dzieciństwa (Незабываемые книги детства, m. 4) книга Золотой ключик вышла в художественном оформлении Малгожаты Коморовской. Кстати, в этой же серии кроме польских классиков детской литературы

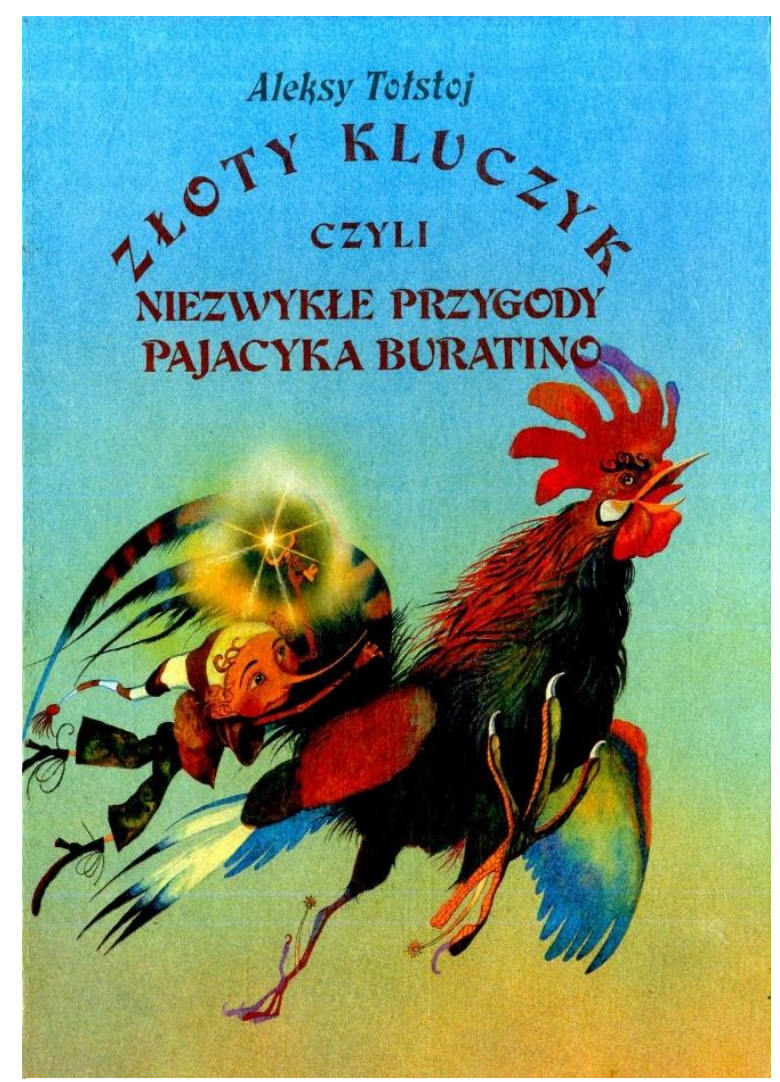

Рисунок 9 - Обложка издания: «Złoty kluczyk czyli niezwykte przygody Buratino» Алексея Толстого в переводе Ю. Тувима в художественном оформлении Малгожаты Коморовской, издательство Votum (1992).

были изданы также сказки Ивана Крылова, Александра Пушкина и Льва Толстого (т. 2), рассказы Антона Чехова (т. 11), Приключения барона Мюнхаузена Рудольфа Распе и др. Последнее издание Золотого ключика было выпущено в 2014 году в издательстве «Zysk i S-ka» с иллюстрациями Бэаты Хорыньской. Авторы интернет-блогов высоко оценивают художественное оформление этого издания. Красивые картинки дополняет твердая обложка, закругленные углы иэффект бумаги в клетку ${ }^{20}$.

Что интересно, читатели, сравнивая книгу Толстого с Пиноккио Коллоди, отмечают существенную разницу между ними. Она заключается, во-первых, в языке, в вовторых, в некоторых мотивах: «[...] obie historie różnią się od siebie diametralnie i naprawdę ciężko uznać, by Aleksy Tołstoj zaczerpnął z powieści Carla Collodiego coś więcej, niż samą postać ożywionej kukiełki» (онлайн). Стоит еще упомянуть, что в Польше издательством «Olejesiuk» выпущена всего одна книжная адаптация Приключений Буратино для детей младшего возраста (автор Гордан Малетич, перевод Анна Матусик-Дыяк, художник Ана Григориев).

В польском контексте вообще невозможно говорить о субкультуре книги

\footnotetext{
${ }^{20}$ Сайты, на которых можно найти рецензии Золотого ключика:

http://jedennatydzien.blogspot.com/2015/02/aleksy-tostoj-zoty-kluczyk-czyli.html http://recenzjeami.blogspot.com/2014/12/zoty-kluczyk-aleksy-tostoj.html http://www.dzieciakitestuja.pl/2015/01/zoty-kluczyk-czyli-inne-przygody.html [дата обращения 12.12.2018].
} 
Золотой ключик, она никогда не стала здесь настолько общеизвестной и популярной, как в России. Тем не менее ее присутствие заметно в культурной жизни Польши как в кино, так и в театре. Кукольный фильм Золотой ключик Александра Птушко 1939 года и мультфильм Приключения Буратино (1959), снятый Дмитрием Бабченко и Иваном Ивановым-Вано, были знакомы польскому зрителю. К сожалению, мне не удалось уточнить дату премьеры. Однако, есть свидетельства, что в 1949 году польский поэт Ян Бжехва написал поэтический перевод текста фильма Александра Птушко (Woźniak, Biernacka-Licznar, Staniów 2014, 30) ${ }^{21}$.

Интересно, что театральные режиссеры иногда сознательно выбирают текст Алексея Толстого в качестве основы для представления приключений деревянной куклы, указывая на динамичность сюжета, отсутствие лишней дидактики и развернутый мотив кукольного театра (Bardijewska 2004, online). Всего Электронная Энциклопедия польского театра насчитывает семь постановок по мотивам сказки Толстого с 1955 года (online). Премьера спектакля под заглавием Złoty kluczyk состоялась в 1958 году в Кукольном театре «Guliwer» в Варшаве. Текст пьесы написала Екатерина Борисова, перевела Кристына Снядецка. Самые последние постановки по мотивам сказки Золотой ключик подготовили: Театр «Lalka» из Варшавы (Buratino, 2004), Kielecki Teatr Tańca (Złoty kluczyk, czyli przygody Pinokia, 2011) и Кукольный театр «Banialuka» из города Бельско-Бяла $(2017)^{22}$. Режиссер последней из указанных постановок - Мариан Пэцки так объяснил свой выбор: «Posługiwaliśmy się tekstem Tołstoja, który jest bardziej rozbuchany, ma więcej tropów i odniesień» (Odziomek 2017, online).

\section{«Золотой ключик» в Польше - критика и восприятие}

Рассуждая о критической литературе, рассматривающей сказку Алексея Толстого, следует подчеркнуть, что читатели и исследователи разделились на две равные группы: тех кто обожает Пиноккио, и тех, кто предпочитает книгу Толстого. Приведу примеры: знаменитая исследовательница детской литературы Стефания Вортман в конце 50-х годов в книге Baśń w literaturze i życiu dziecka критично высказывается о книге Алексея Толстого. Она упрекает советского писателя в неубедительном окончании книги. По ее мнению, раскрытая тайна театра кукол, спрятанного за дверями, разочаровывает читателя. Стефания Вортман обвиняет писателя в том, что он лишил свое произведение элемента фантастики, нарушил гармонию между

\footnotetext{
${ }^{21}$ Jan Brzechwa, Złoty kluczyk: streszczenie filmu radzieckiego podług bajki G. Collodiego, Wydawnictwo PP "Film Polski". Centralny Zarząd Rozpowszechniania Filmów, 1949.

${ }^{22}$ Encyklopedia Teatru Polskiego (онлайн) насчитывает всего семь постановок по мотивам сказки Толстого начиная с 1955 года.
} 
выдумкой и реальностью, напрасно сделал произведение современным (Wortman 1958, 81) 23 . Сходным образом высказывается изнаток детской литературы профессор Гжегож Лешчиньски на пятьдесят лет позже. В интервью он говорит, что Толстой переработал знаменитое произведение, сделав из него вещь «незнаменитую», опошляя его. И не случайно эта книга унас почти неизвестна. Исследователь утверждает, что ребенку всегда лучше дать оригинал, чем переделку (Kęczkowska 2004 online).

Такая резкая критика произведения вытекает из непонимания текста, поверхностного чтения, а также из-за стереотипного восприятия советской литературы. Сказку Толстого часто несправедливо обвиняют в коммунистической пропаганде (Świetlicki 2015, 237). Марк Липовецкий в своей статье доказывает, что Буратино по своей природе трикстер - аморальный озорник, хулиган и нарушитель условностей, он совсем не вписывается в социалистическую идеологию:

Он наиболее безыдейный персонаж советской культуры, никак не связанный ни с какими социальными или идеологическими моделями. Показательно, что, войдя в канон соцреализма, сказка Толстого не вмещается в соцреалистический протосюжет в том виде, в каком его описывает К. Кларк: социальные обретения Буратино не оплачены ростом его "сознательности" - он, вопреки соцреалистическому канону, так и остается “стихийным" героем (Липовецкий 2003, online)

Можно предположить, что успех книги в СССР и ее вхождение в канон в советской литературе принесли противоположные результаты в Польше, что стало особенно заметно после введения рыночных отношений. Клеймо коммунистического произведения негативно повлияло на восприятие Золотого ключика после 1989 года. Ханна Балтын в рецензии спектакля по мотивам сказки Толстого отмечает, что книга стала жертвой «дикой люстрации» (Baltyn 2005, online).

Несмотря на это, можно найти доказательства, что у Золотого ключика есть свои поклонники. Есть среди них исследователи, которые называют версию Толстого остроумной (Woźniak, Biernacka-Licznar, Staniów 2014, 29) или ни в чем не уступающей оригиналу (Woźniak 2013, 31-32), а также отвечающей детским потребностям (Kadykało 2014, 554). Критики отмечают, что сказка Толстого менее жестока, чем оригинал Коллоди (Kęczkowska 2004, online

\footnotetext{
${ }^{23}$ Интересным может показаться совсем противоположное мнение Малгожаты Вуйцик-Дудэк, которая упрекает именно Карло Коллоди в том, что заключение его книги неубедительно. По мнению исследовательницы, Пиноккио должен остаться марионеткой. Кроме того, Малгожата ВуйцикДудек замечает, что отрицательные персонажи в книге Карло Коллоди в отличие от варианта Толстого, не были наказаны за свои поступки. Это полностью противоречит законам сказочного жанра (Wójcik-Dudek 2012, 14-17).
} 
http://warszawa.wyborcza.pl/warszawa/1,34861,2402008.html), а с другой стороны лишена раздражающего морализаторства, свойственного педагогике XIX века (Olech 2011, online). На различных интернет форумах и блогах читатели тепло высказываются о книге и особенно высоко оценивают перевод Юлиана Тувима. http://lubimyczytac.pl/ksiazka/242744/zloty-kluczyk-czyli-niezwykle-przygody-pajacykaburatino

\section{О переводе «Золотого ключика»}

На всех польских изданиях Золотого ключика стоит одна ита же фамилия переводчика. Юлиан Тувим (1894-1953) - великолепный польский поэт, сатирик и детский писатель, родился в еврейской семье в городе Лодзь. Тувим принадлежал к модернистской поэтической группе «Skamander». Лингвистические способности и увлечения он унаследовал от отца. Тувим знал эсперанто, греческий, идиш, переводил с латыни, русского, французского и немецкого языков. Поэт является автором незабываемых детских стихотворений, среди которых Lokomotywa, Bambo, Okulary. Он также перевел с русского языка на польский Слово о полку Игореве, Горе om ума Грибоедова, стихотворения и поэмы Пушкина (Медный Всадник, Руслан и Людмила), поэтические тексты Маяковского атакже детские произведения Самуила Маршака и Сергея Михалкова. О настоящем увлечении Тувима российской поэзией и русским языком пишет Петр Мативецки в книге Twarz Tuwima. В стихотворениях поэта можно заметить, что его вдохновляла поэзия Пушкина, Брюсова, Иванова, акмеистов и футуристов. Биограф приводит слова поэта Чеслава Милоша, упрекающего Тувима в том, что он хотел писать по-польски, так как пишется по-русски, то есть повторить ритм и мелодию характерную для русского языка (Matywiecki 2008, 280)24. Примечательно, что после войны Тувим с надеждой и одобрением принял политические перемены в стране, за что его в последствии сильно критиковали.

Кто же был автором перевода книги Золотой ключик или приключения Буратино? Существуют серьезные подозрения, что автором перевода является младшая сестра поэта - Ирена Тувим. Исследовательница Моника Возьняк ссылается на воспоминания Ирены Тувим, по словам которой, брат из-за нехватки времени попросил сестру сделать этот перевод вместо него (Woźniak 2012, 118). Работа начинающей переводчицы была высоко оценена издателем, но именно

\footnotetext{
${ }^{24}$ Русская культура всегда была близка сердцу поэта, он учился в русскоязычной гимназии. В возрасте 11-12 лет даже не принял участие в школьной антироссийской забастовке, друзья его за это возненавидели (ibidem, 281). Сложные отношения между поляками и русскими Тувим представил в поэме Kwiaty polskie.
} 
Юлиан Тувим подписался под переводом (Tuwim, 1981). Стоит однако заметить, что деньги за работу Юлиан передал Ирене и этот факт может подтверждать ее версию (Augustyniak 2016, 113-114). Тайной останется, какое участие в окончательном переводе принял Юлиан и насколько текст являлся самостоятельной работой Ирены. Отношения между Иреной и ее старшим братом Юлианом были очень близкими, они разделали поэтические увлечения, читали и комментировали друг другу свои стихи. Хочется подчеркнуть, что со временем Ирена Тувим стала замечательной переводчицей, прежде всего английской литературы, ей принадлежит классический перевод на польский язык книги Винни-Пух Алана Милна (Kubuś Puchatek, 1926). Несомненно у нее был поэтический талант, уже с юных лет писала стихотворения и со временем стала, так же как и брат, автором произведений для детей (Marek Wagarek 1955, Pampilio 1962). Примечательно, что Ирена никогда не получила широкой известности, так как всегда жила в тени двух любимых мужчин - брата и мужа (переводчика - Юлиана Ставиньского).

Несмотря на все сомнения по поводу авторства перевода, это никак не повлияло на оценку его качества. Его автору удалось передать динамичность текста, особенности разговорного стиля в высказываниях персонажей, сохранить звуковую сторону русского подлинника (фонетическая редупликация, восклицания, повторения, звукоподражательные слова, разговорная лексика, ласкательноуменьшительные слова ит.п.). Этой теме посвящена статья Беаты Рыцельской О количественной иконичности в сказке Алексея Толстого "Золотой ключик или приключения Буратино» иее польском переводе (Рыцельска 2018, 93-106). Рыцельская приводит многочисленные примеры количественной иконичности (принцип больше формы-больше содержания) в тексте Толстого:

\begin{tabular}{|c|c|c|c|}
\hline 1. & $\begin{array}{l}\text { Оччччень мне нужны советы старого } \\
\text { сверчка... (17) }\end{array}$ & & $\begin{array}{l}\text { Strrrrrrasznie potrzebne mi są rady starego } \\
\text { świerszcza... (13) }\end{array}$ \\
\hline 2. & $\begin{array}{l}\text { Мне ужжжжжжжасно хочется посмотреть } \\
\text { кукольный театр! - сквозь слёзы сказал } \\
\text { Буратино.(24) }\end{array}$ & 2. & $\begin{array}{l}\text { Tak bym strrasznie chciał zobaczyć teatr } \\
\text { kukiełek - ze łzami w oczach powiedział } \\
\text { Buratino (18) }\end{array}$ \\
\hline 3. & $\begin{array}{l}\text { 3. Задевая мягким крылом за его нос, } \\
\text { Сплюшка повторяла: - Не верь, не верь, не } \\
\text { верь! (40) }\end{array}$ & 3. & $\begin{array}{l}\text { 3. Trqcajqc go lekko skrzydłami w nos, sówka } \\
\text { powtarzała: - Nie wierz im, nie wierz im, nie } \\
\text { wierz im! (30) }\end{array}$ \\
\hline
\end{tabular}

Таблица 2 - Примеры количественной иконичности в польском переводе

Заметно, что благодаря редупликации фонем $(1,2)$, повторениям слов или целых синтагм (3), усиливается их значение или могут быть выражены разные эмоции как, например, неуважение к словам старого сверчка (1). 
Диалоги между героями являются примером «живой речи», в них используется разговорная лексика, лаконичные и меткие реплики, полные эмоции. Как можно заметить в приведенных цитатах, в местах, где оригинально применяется автором разговорный стиль, переводчик тоже использует разговорную лексику (хныкать - chlipać, дуралей - dureń, отколотить - okładać) и пытается восстановить индивидуальный стиль речи героев.

- Ты чего хнычешь, дуралей?

ответил Пьеро.

- А почему ты не женился?

- Потому что моя невеста от меня убежала...

- Ха-ха-ха, - покатился со смеху

Арлекин, - видели дуралея!

Он схватил палку и отколотил Пьеро. (28)

- Czego chlipiesz, durniu?

- Jestem smutny, bo chcę się żenić - odparł Pierot.

- A czemuś się nie ożenit?

- Bo mi narzeczona uciekła...

- Cha-cha-cha! - zatoczył się ze śmiechu Arlekin. - Widzieliście durnia! Złapał kij i zaczął okładać Pierota. (33)

Таблица 3 - примеры польских переводов «живой речи»

Хочется подчеркнуть, что язык героев Толстого (особенно реплики самого Буратино) прекрасно отражает их характер иощущения в данной ситуации. Эмоциональная насыщенность высказываний достигается путем употребления междометий и восклицаний (довольно - dosyć, akurat), экспрессивных глаголов (пошли прочь - wynosić się, лизаться -_lizanie) и оценочных существительных, а также благодаря инверсии в предложениях (Очень нужно мне, я вам не дохлая кошка). Переводчику в основном удается передать эмоциональность и динамику диалогов при помощи тех же приемов, что и в исходном тексте, хотя не во всех случаях (например, в приведенных ниже фрагментах Тувим не использует инверсию, но чаще, чем у Толстого, использует междометия - Dalej przedstawienie! Akurat!).

\begin{tabular}{|c|c|}
\hline $\begin{array}{l}\text { - } \text { Очень нужно мне раскаиваться! Не } \\
\text { дождётесь. (62) }\end{array}$ & $\begin{array}{l}\text { - } \quad \text { Akurat! Będę żałował!... } \\
\text { Niedoczekanie...(75) }\end{array}$ \\
\hline $\begin{array}{l}\text { Буратино это наконец надоело, он зашлёпал } \\
\text { пятками по воде: } \\
\text { - } \quad \text { Пошли прочь! Я вам не дохлая кошка. (71) }\end{array}$ & $\begin{array}{l}\text { Buratino miał wreszcie tego dosyć, więc zatupotał } \\
\text { gniewnie piętkami po wodzie. } \\
\text { - } \quad \text { Wynosić się! Nie jestem zdechłym kotem! }\end{array}$ \\
\hline $\begin{array}{l}\text { Только мальчишки на задних скамейках сердились } \\
\text { и топали ногами: } \\
\text { - Довольно лизаться, не маленькие, } \\
\quad \text { продолжайте представление! (32) }\end{array}$ & $\begin{array}{l}\text { Tylko chłopcy z ostatnich rzędów złościli się i tupali } \\
\text { nogami. } \\
\text { - Dosyć tego lizania! Coście wy - dzieci? Dalej } \\
\quad \text { przedstawienie! (33) }\end{array}$ \\
\hline
\end{tabular}

Таблица 4 - Примеры эмоциональной насыщеенности перевода 
Не потерялось в переводе чувство юмора и индивидуальный стиль писателя Алексея Толстого, что подтверждает нижеприведенный фрагмент. В эпизоде, проникнутом юмором, Богомол говорит совершенно абсурдные вещи по поводу состояния пациента и наконец притворяется «мертвым» и убегает. Польский вариант вызывает те же ощущения и образы учитателя, что и оригинал, а это наилучшее доказательство высокого качества перевода.

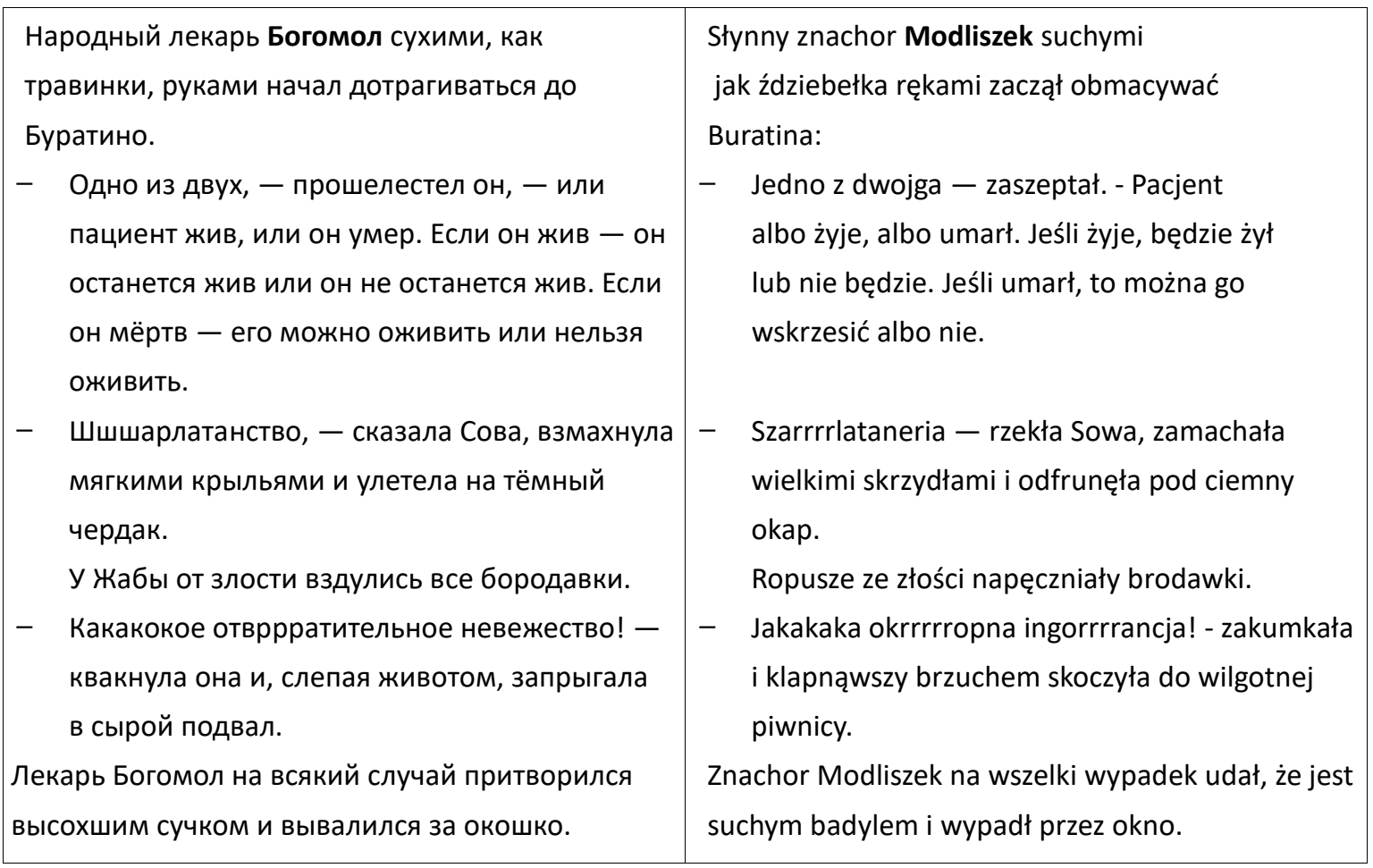

Таблииа 5 - Примеры перевода смешного

Интересным примером несовпадения языковых систем польского и русского языка является перевод слова Богомол - название этого насекомого по-польски выражается существительным женского рода modliszka. Переводчик создал неологизм (Modliszek), чтобы передать принадлежность героя к мужскому полу. Хочется добавить, что одним из главных различий между переводом и оригиналом является отсутствие в польском тексте перевода песни «Полька птичка», которую поют куклы в театре. Остальные песни и стихотворения, которые Пьеро читает Мальвине, переведены с поэтическим мастерством.

Особого внимания заслуживает перевод имен собственных в польской версии Приключений Буратино. Я попыталась их дополнительно сравнить с именами героев в польском переводе Пиноккио Ярослава Миколаевского. По мнению Марии Ненароковой, «Имена персонажей относятся к ключевым словам текста, их смысл проявляется по мере прочтения текста. Изучение имен собственных в тексте позволяет глубже понять систему его образов, часто служит ключом кего интерпретации, особенностям композиции» (Ненарокова 2018, 25). 


\begin{tabular}{|c|c|c|}
\hline Толстой & Тувим & Пиноккио Миколаевский \\
\hline Крыса Шушара & Szczur Szurszur & - \\
\hline Папа Карло & Papa Carlo & Geppetto \\
\hline Буратино & Buratino & Pinokio \\
\hline Говорящий Сверчок & Gadający Świerszczyk & Świerszcz-Który-Mówi \\
\hline Джузеппе & Beppo & Majster Czereśnia \\
\hline Мальвина & Malwina & $\begin{array}{l}\text { Niebieskowłosa Dziewczynka/ } \\
\text { Wróżka }\end{array}$ \\
\hline Карабас Барабас & Karabasz Barabasz & Ogniożerca \\
\hline Лиса Алиса & Lisica Petronela & Lis \\
\hline Кот Базилио & Kot Bazyli & Kot \\
\hline $\begin{array}{l}\text { Дуремар } \\
\text { (продавец лечебных пиявок) }\end{array}$ & Drągajło & - \\
\hline Букашка-таракашка & Muszka-rajcuszka & - \\
\hline Пудель Артемен & Pudel Artemon & Pudelek Medora \\
\hline Арлекин и Пьеро & Arlekin i Pierot & Arlekin i Poliszynel \\
\hline
\end{tabular}

Таблица 6-Сравнение собственных имен в русском оригинале и в польских переводах

Анализируя приведенные в таблице примеры можно сделать вывод, что большинство имен собственных переведено точно, как по смыслу, так ипо звучности. Лишь некоторые совсем не совпадают (Lisica Petronela, Drągajło). Переводчик решил заменить имя Дуремар именем Drągajło, которое звучит похоже, но относится к внешнему виду героя, а не к профессии (дуремар это архаизм со значением «доктор»). По польски сарлово dragal от которого происходит имя Drągajło, означает очень высокого и неуклюжего человека (Słownik Języka Polskiego PWN, online). Дополнительно используемый переводчиком суффикс - ajło, усиливает отрицательное значение этого слова (Gala 1993, 78-79).

Хочется обратить внимание на то, что, переводя имена Джузеппе и Шуршур, автор польского перевода сосредоточивается на фонетическом сходстве переводного слова и оригинала (Верро, Szurszur), хотя и нельзя говорить о стопроцентной эквивалентности, как в случае имен главных героев (Буратино и Карабас-Барабас), которые по-польски звучат так же. Интересным примером таланта переводчика является перевод уменьшительного названия насекомого букашка-таракашка, который по польски звучит muszka-rajcuszka. Как видми, переводчик решил изменить вид насекомого, чтобы сохранить звуковое сходство 
слов и их ласкательно-уменьшительное значение. Таблица указывает также на отсутствие некоторых имен персонажей в польском переводе Пиноккио, что связано с существенными отличиями в сюжете книг.

Наконец, учитывая результаты анализа, хочется подчеркнуть, что главное достоинство польского перевода заключается в том, что перечитывая его, мы не чувствуем, что он был написан в 30-ые годы XX века. Это свидетельствует о том, что перевод не устарел, как это происходит со многими переводами классики.

\section{Заключение}

Подводя итоги, необходимо указать на существенную разницу между восприятием книг Пиноккио и Золотой ключик в Польше и России. Сказка Карло Коллоди в польской детской культуре приобрела статус книги, принадлежащей к литературному канону. Это обеспечивает книге читателей, хотя в связи с быстро меняющимися трендами в детской литературе, их может быть меньше, чем раньше. По контрасту, в России Пиноккио почти неизвестен, зато Буратино выдержал испытание временем и вошел вряд русских культурных архетипов наряду с Чапаевым и Штирлицем.

История и политика помешали объективной оценке книги Алексея Толстого в Польше и, следовательно, в восприятии ее как художественного произведения. На данный момент книга полностью исчезла с читательского рынка, и ее постепенно забывают. Однако анализ перевода книги указывает на привлекательность польского текста и высокий художественный уровень перевода. Это доказывает, что книга в Польше могла бы приобрести обширную группу читателей, если бы не клеймо «советской книги».

\section{Итальянский оригинал и русский перевод - Пиноккио и Буратино В чешском контексте}

\section{(Ева Кудрявцева Маленова)}

В предыдущей главе рассматривалось положение русской детской литературы в польском контексте. Большинство найденных тенденций можно обнаружить не только в польских, но и в чешских переводах. Однозначным рубежом в чешском контексте является 1989 год, т. е. год т. наз. Бархатной революции. Конкретные последствия, проявившиеся после упомянутого переворота, описаны в конце данной главы. 


\section{Коллоди и Пиноккио в чешском контексте}

Карло Лоренцини известен в мире детской литературы под псевдонимом Карло Коллоди, который прославила его книга "Le Avventure di Pinocchio» (отдельным изданием вышла впервые в 1883 году). Этот успех не обошел чешских читателей. Первый перевод на чешский язык «Oříškova dobrodružství» был выполнен Франтишеком Повером в 1908 году, и на сегодняшний день можно говорить одостойной переводческой истории данной книги. В 2018 году в Карловом университете возникла бакалаврская работа, посвященная сравнительному анализу четырех основных, несокращенных чешских переводов «Пиноккио» (HOLANEC, 2018). Отметим лишь изменения названия и годы новых переводов:

- 1908 г. - переводчик Франишек Повер «Oříškova dobrodružství»

- 1941 г. - переводчик Отакар Кунстовны «Nosáčkova dobrodružství»

- 1962 г. - переводчики Ян и Марие Голицких «Pinocchiova dobrodružství» (самый распростаненный перевод, - см. историю переизданий: в 1969, 1976, 1988, 1995, 2007 а 2013гг.)

- 2008 г. - переводчица Зора Обстова «Pinocchiova dobrodružství»

На сегодняшний день доступны не только вышеуказанные переводы на чешский язык, но также целый ряд адаптированных произведений массового характера, которые связаны прежде всего с фильмами ${ }^{25}$ и продукцией компании «Walt Disney» - они стали распространяться в Чехии особенно интенсивно с 90-х годов 20 века (напр. тетради-разрисовки, картонные книги ит. д.), т. е. можно констатировать, что тенденции в Чехии похожи на тенденции в Польше (см. предыдущую главу). В итоге можно согласиться со словами М. Ржезачовой, что «книгу «Приключения Пиноккио» можно считать классикой мировой литературы для детей имолодежи, иона является одним из самых известных итальянских произведений. Книгу перевели больше чем на 24 языка, у нее есть несколько продолжений, существуют обработки для фильма, для театра, для комикса, именем главного героя назвали даже астероид.» (Мандыс, 26).

\footnotetext{
${ }^{25}$ Кроме самого известного мультфильма существует еще фильм компании «Walt Disney» с названием «The Adventures of Pinocchio» - т. е. «Приключению Пиноккио» (1996), который отчасти снимался на улицах чешского города Чески-Крумлов.
} 


\section{Коллоди и Пиноккио в русском контексте}

Данную тему открыла П. Вантух в предыдущей главе, но ее важно еще немного дополнить. Начнем с фактов. В России сказку Коллоди впервые перевел С.В.Павловский под названием «Приключения Фисташки. Жизнеописание Петрушки-марионетки» в 1906 году, затем появлялись другие издания и редакции на русском языке. Однако, Пиноккио не стал шедевром - «but Pinocchio had never really caught on in Russia» (HELLMAN, 2013, 421). Во время Советского Союза оригинальный «Пиноккио» на русском языке издавался только в 1959 году в переводе Г. Казакевича (HELLMAN, 2013, 422), и можно констатировать (согласно каталогу Российской государственной библиотеки), что данный перевод лежит и в основе немногочисленных постсоветских изданий оригинального произведения Коллоди.

Гораздо большей популярностью пользуется до сих пор книга, написанная А. Н. Толстым по мотивам Коллоди: «Золотой ключик, или Приключения Буратино». В предисловии к изданию 2016 года написано: «Сказочный мир и герои А. Толстого созданы настолько живо и ярко, что вот уже больше полувека у сказки о Буратино каждый год появляется множество новых юных поклонников. В 2016 году исполнилось 80 лет со дня первой публикации книги в нашей стране.» (ТОЛстОЙ, 2016). Вполне правдоподобно, что большую роль вобщероссийском успехе Буратино сыграли еще два факта:

1. Успешная театральная постановка. Данную мысль предлагает Б. Хеллман: «The play version of 1936 also enjoyed great success at the Central Children's Theatre in Moscow.» (HELLMAN, 2013, 421)

2. Успешная экранизация. Б. Хеллман отмечает фильм 1939 года режиссера Александра Птушко - «it was a landmark in the history of Soviet children's culture» (HELLMAN, 2013, 422). Однако, гораздо более культовыми стали двухсерийный телевизионный фильм, созданный в 1975 году, и мультфильм, возникший в 1959 году. Не в последнюю очередь можно упомянуть новое продолжение приключений, вышедшее в 2013 году под названием «Возвращение Буратино».

Итак, посмотрим ближе на произведение, созданное в советской России на основе итальянской сказки. 


\section{«Золотой ключик» А. Толстого}

Напомним вкратце, что Алексей Николаевич Толстой (1883-1945) переработал популярную ктому времени книгу итальянского автора, и первое издание «его» произведения на русском появилось в России в 1936 году (т. е. практически полвека спустя после появления итальянского оригинала). Работал он при этом с переводом Нины Петровской (HELLMAN, 2013, 421) и многое существенно изменил. Некоторые избранные моменты сравнительного анализа итальянского оригинала и русского «воссоздания» приведены нами ниже, далее обращено внимание на сравнительный анализ собственных имен (в предыдущей главе сравнение русско-польское, в данной главе русско-чешское). При этом необходимо отметить, что полный сравнительный анализ не является целью нашей работы.

\section{«Золотой ключик» и его место в русской литературе}

Произведение А. Толстого стало неотъемлемой частью истории русской детской литературы 20 века, и его популярность не угасла с концом советского периода и даже в конце 20 века. В каталоге Российской государственной библиотеки за 2016 год можно найти десять изданий (в разной степени обработки):

\section{1. Толстой, Алексей Николаевич (1882-1945).}

Золотой ключик, или Приключения Буратино [Текст] : повесть-сказка : [для младшего школьного возраста] / Алексей Толстой ; худож. Н. Шеварёв. - Москва : MAXAOH, 2016. - 142, [1] с. : ил.; 25 см. - (Библиотека детской классики).; ISBN 978-5-389-10470-9 : 5000 экз.

\section{2. Толстой, Алексей Николаевич (1882-1945).}

Золотой Ключик, или Приключения Буратино [Текст] : [для среднего школьного возраста : 0+] / А. Толстой ; рис. Аминадава Каневского. - Москва : Эксмо, 2016. 109, [2] с. : ил.; 23 см. - (Золотое наследие).; ISBN 978-5-699-86807-0 : 5000 экз.

3. Толстой, Алексей Николаевич (1882-1945).

Золотой ключик, или Приключения Буратино [Текст] : [для младшего школьного возраста : 6+] / А. Н. Толстой ; рис. А. Каневского. - Москва : АСТ, Малыш, 2016. 110, [1] с. : цв. ил.; 27 см. - (Серия "Мировая классика для детей").; ISBN 978-5-17096640-0 : 4000 экз.

4. Приключения Буратино, или Золотой ключик [Текст] : [повесть-сказка : в сокращении : для дошкольного возраста : 0+] / А. Толстой ; худож. Л. Владимирский. - Москва : АСТ, Малыш, сор. 2016. - 46, [1] с. : цв. ил.; 22 см. (Всё для детского сада).; ISBN 978-5-17-099302-4 
5. Толстой, Алексей Николаевич (1882-1945).

Золотой ключик, или Приключения Буратино [Текст] : повесть-сказка : [для младшего школьного возраста : 0+] / Алексей Толстой ; худож. Аминадав Каневский. - Москва : МАХАОН, 2016. - 158, [1] с. : ил.; 22 см. - (Чтение - лучшее учение).; ISBN 978-5-389-10691-8 : 12000 экз.

6. Толстой, Алексей Николаевич (1882-1945).

Золотой ключик или Приключения Буратино [Текст] : [сказка : для детей дошкольного возраста : 0+] / А. Н. Толстой ; рис. Г. Бедарева. - Москва : Фламинго, 2016. - 110, [1] с. : цв. ил.; 27 см. - (Сказка А. Н. Толстого в адаптации для малышей).; ISBN 978-5-7833-1806-1 : 5000 экз.

7. Толстой, Алексей Николаевич (1882-1945).

Золотой ключик, или Приключения Буратино [Текст] : [для чтения взрослыми детям : 0+] / Алексей Толстой ; [худож. Петр Северцов]. - Москва : УМка : СТрейд, 2016. - 159 с. : цв. ил.; 26 см. - (Детская библиотека).; ISBN 978-5-50600900-9 : 5000 экз

8. Толстой, Алексей Николаевич (1882-1945).

Золотой Ключик, или Приключения Буратино [Текст] : [для среднего школьного возраста : 0+] / А. Толстой ; ил. Ольги Зобниной. - Москва : Эксмо, 2016. - 153, [6] с. : цв. ил.; 22 см. - (\#Эксмодетство).; ISBN 978-5-699-89453-6 : 5000 экз.

9. Толстой, Алексей Николаевич (1882-1945).

Золотой ключик, или Приключения Буратино [Текст] : книжка-комби : [по сказке А. Толстого "Золотой ключик, или Приключения Буратино] / [А. Толстой]. [Россия] : [б. и.], [2016]. - [32] с. : цв. ил.; 27 см

10. Толстой, Алексей Николаевич (1882-1945).

Приключения Буратино, или Золотой ключик [Текст] : [сказка : книжка-картинка : для дошкольного возраста : 0+] / А. Толстой ; худож. Леонид Владимирский. Москва : АСТ, Малыш, сор. 2016. - 76, [3] с. : цв. ил.; 27 см. - (Я читаю сам!).; ISBN 978-5-17-099504-2 : 4000 экз.

Как уже упомянуто выше, некоторые из найденных нами изданий являются адаптациями (см. пункт шестой) или это книжки-картинки для самых маленьких (см. пункт десять), но повторим, что это в очередной раз подтверждает основную и прочную позицию Буратино в русской детской литературе. 
На основе того же каталога РГБ можно сравнить количество книг Коллоди, изданных в 2016 году на русском языке:

1. Коллоди, Карло (1826-1890) Collodi, Carlo (1826-1890).

Приключения Пиноккио [Текст] : история деревянного человечка : [6+] / Карло Коллоди ; [пер. с итал. Эм. Казакевича]. - Москва : Издательский дом Мещерякова, 2016 . - 239 с. : цв. ил. ; 25 см. - Пер.: Collodi, Carlo. Pinocchio. ISBN 978-5-91045-912-4:3100 экз.

2. Коллоди, Карло (1826-1890) Collodi, Carlo (1826-1890).

Приключения Пиноккио [Текст] : [сказка : для среднего школьного возраста] / Карло Коллоди ; пер. с ит. Э. Казакевича ; ил. М. Митрофанова . - Москва : РОСМЭН, 2016 . - [200] с. : ил. ; 32 см. - ISBN 978-5-353-08087-9:2000 экз.

3. Коллоди, Карло (1826-1890) Collodi, Carlo (1826-1890).

Приключения Пиноккио [Текст] = The adventures of Pinocchio / Карло Коллоди ; адапт. текста Г. К. Магидсон-Степановой ; упражнения, слов. С. В. Монахова . Москва : АЙРИС ПРЕСС, 2016 . - 205, [1] с. : ил. ; 21 см. - (Английский клуб. Elementary).. - (Домашнее чтение). - ISBN 978-5-8112-6395-0:5000 экз.

\section{4. Коллоди, Карло (1826-1890) Collodi, Carlo (1826-1890).}

Приключения Пиноккио [Текст] : [для детей до 3 лет : 0+] / Карло Коллоди ; [пер. с итал. К. Данини ; худож. Катя Лонги] . - Москва : Эксмо, 2016 . - 30, [1] с. : цв. ил. ; 29 см. - (Самые красивые сказки). - Фактическая дата выхода в свет - 2015. - ISBN 978-5-699-82395-6:5000 экз.

\section{5. Коллоди, Карло (1826-1890) Collodi, Carlo (1826-1890).}

Приключения Пиноккио [Текст] : [для среднего школьного возраста : 6+] / Карло Коллоди ; [пер. с итал. К. Данини]; ил. Либико Марайя . - Москва : Эксмо, 2016. - 169, [2] с. : цв. ил.; 33 см. - Фактическая дата выхода в свет - 2015. - ISBN 978-5699-85213-0:3000 экз.

Заметно, что первые две книги (пункты один, два) основаны на переводе Э. Казакевича, возникшем больше полувека назад. Третья книга является двуязычным изданием, популярным ныне в обучении иностранным языкам, однако иностранный текст приведен не в итальянском оригинале, как можно было бы ожидать, а на английском языке (см. пункт три). Четвертая и пятая книга основаны на переводе Камиллы Данини, который возник более чем 100 лет назад - при этом четвертый пункт содержит лишь 30 страниц, итаким образом, является сокращенной обработкой для самых маленьких детей. Из пяти изданий лишь три 
предназначены для детей школьного возраста и соответствуют по объему итальянскому источнику. В связи с тем, что все три упомянутые издания основаны на старых переводах, может возникнуть вопрос - связан ли этот факт с издательской тенденцией экономить расходы (в том числе на перевод), или с высоким качеством и жизнеспособностью старых переводов. И. Минералова в своем сравнительном анализе наглядно показала недостатки перевода Казакевича (Минералова, 125), хотя целью исследовательницы было не выявление качества перевода, а сравнение итальянского сюжета с переводом А. Толстого. Однако, основываясь на вышеуказанном, мы вправе предполагать, что большую роль, чем качество старых переводов, у современных издателей играет экономическая функция. Этот тезис можно поддержать небольшой популярностью, которой пользуется текст Коллоди в современной России по сравнению с текстом А. Толстого.

\section{От Коллоди к Толстому - избранные вопросы сравнительного анализа}

Исследователи (Хеллман, Минералова) обычно обращают внимание на само название книг - и это на самом деле показательный пример. У Толстого выходит на первый план сюжетообразующая деталь - золотой ключик, тогда как у Коллоди в центре внимания лежат «приключения». Можно согласиться с И. Минераловой, что само название Толстого более конкретно, сжато и приспособлено для маленьких читателей (Минералова, 125).

При сравнении оригинала и русского переложения (в связи с текстом А. Толстого нами намеренно не используется термин «перевод») можно отметить следующие важные отличия:

1. Алексей Толстой придерживался (более или менее) итальянского оригинала лишь до главы, в которой главный герой теряет полученные монетки (т. е. у Коллоди - главы 19/20, у Толстого глава 16-ая).

2. Далее у Коллоди преобладают ПРИКЛЮЧЕНИЯ Пиноккио (см. название), связанные с мечтой деревянной куклы стать человеком. У Толстого начинается борьба за золотой ключик (см. название), это не только предмет, это символ, открывающий дорогу кновой счастливой жизни, спрятанной пока за неизвестной, запертой дверью.

3. Если Толстой одну сюжетообразующую деталь (золотой ключик) додумал, то другие пропустил. В общем, можно заметить, что произведение Толстого более сжато (по объему намного короче - см. первые пункты у приведенных нами 
выше изданий 2016 года - в издательстве «MAXАOН» вышла книга Толстого с объемом 142 страницы, в издательстве «Изд. дом Мещерякова» с объемом 239 страниц).

4. Есть исследователи, которые замечают чрезвычайную жестокость наказаний, следующих за всеми проказами Пиноккио, т. е. указывают на жестокость итальянского оригинала: «Логике характеров персонажей А. Н. Толстого чужда «добродетельная» жестокость героев итальянской сказки» (Шацкий, 111). Стоит обратить внимание на конкретный пример. Е. Шацкий демонстрирует гуманность Мальвины в том, что она плачет (выделила ЕКМ), наказав Буратино тем, что заперла его в темный чулан, тогда как итальянский прототип Коллоди Фея - жестока. Однако, если посмотреть в оригинальный текст на основе чешских переводов, то можно констатировать, что голубоволосая Фея Пиноккио не запирает нигде и никогда. Это он сам запирается - врёт настолько, что запирается своим постоянно растущим носом в ее домике. Однако, как только он осознает свои ошибки и старается быть лучше, Фея всегда его прощает и активно ему помогает.

5. Обратим внимание на то, что Буратино и Пиноккиио - герои непослушные, т. е. могут восприниматься как образы нестандартных детей (в предыдущей главе используется обозначение и теория трикстера М. Липовецкого, можно также удачно использовать термин М. Петровского: «герой-озорник» (Петровский, 161). Но при этом их пути развития разные - Пиноккио, пройдя все испытания, нравственно вырастает из образа деревянной куклы и в награду за это становится человеком. В отличие от него Буратино в своем образе марионетки остается и в конце сюжета находит свое призвание - планирует играть в театре самого себя в спектакле «Приключения Буратино и его друзей».

На этом сравнении мы остановимся - так как представляется нецелесообразным сравнивать оба произведения по их гуманности. Они очень сильно отличаются, причем сравнительный анализ дан уже М. Петровским (Петровский, 148-220). Также не стоит решать оригинальность Коллоди и право на заимствование и переработку Толстого, что особенно популярно в контексте современной погони за плагиатами. Однако, как нами уже отмечено выше, движущей силой искусства является вызов хорошего лучшему. Если бы великие писатели не стремились написать лучше, чем до них было написано, не возникли бы многие известные произведения. Этот вопрос разработали среди других специалистов Ю. и И. Минераловы, и особенно И. Минералова активно возвращает 
в литературоведческий дискурс термин «мимесис (подражание)» (Минералова, 122).

Однако, посмотрим дальше на современные тенденции в чешском восприятии русской литературы для детей имолодежи. Сначала на примере чешских изданий Буратино - Пиноккио.

\section{Алексей Толстой в контексте чешского восприятия}

Можно сразу констатировать, что специфика современного польского восприятия произведения «Золотой ключик», описанная в предыдущей главе, отчасти похожа на чешское восприятие. Алексей Толстой как писатель переводился на чешский язык задолго до написания «Золотого ключика». Одним из первых чешских изданий можно считать книгу, включающую три рассказа Толстого, выпущенную в 1911 году в серии «мировая библиотека» пражским издательством «J. Otto». Можно обратить внимание на то, что после 1989 года появились лишь две книги А. Толстого в чешских переводах. В 2013 году вышел «Золотой ключик» (с указанием «по мотивам А. Толстого» - больше об издании см. дальше) и в 2008 году книга народных сказок с названием “Baba Jaga a jiné pohádky» ${ }^{26}$. При этом до 1989 года выходили не только сказки А. Толстого, а также его прозаические произведения для взрослых.

Напомним, что в Польше вышли новые издания «Золотого ключика» А. Толстого еще в 90-е годы XX века (см. предыдущая глава о польском восприятии), в отличие от Польши, на чешском книжном рынке с 90 годов однозначно доминирует Пиноккио. Многочисленные издания итеатральные постановки А. Толстого сохранились в свободном доступе в каталогах библиотек или в букинистических магазинах, в книжных магазинах их давно нет. Таким образом, можно утверждать, что в чешском контексте в наше время никакой субкультуры, связанной с Буратино нет и, скорее всего, такой субкультуры в чешском контексте и не было. Фильмы о Буратино на чешский не переведены (удалось найти только перевод на словацкий язык), в каталоге Национальной библиотеки можно отыскать лишь две театральные постановки:

\footnotetext{
${ }^{26}$ TOLSTOJ, Aleksej Nikolajevič et al. Baba Jaga a jiné pohádky. Překlad Zdeňka Psůtková a Jana Mertinová. Praha: Reader's Digest Výběr, 2008. 351 s. ISBN 978-80-7406-006-9.
} 
1. ČAPOUN, Jiří a TOLSTOJ, Aleksej Nikolajevič. Dobrodružství dřevěného panáčka: pohádkový př́běh o 5 obrazech napsaný volně na motivy A. Tolstého. Praha: Dilia, $1984.52 \mathrm{~s}$.

2. BORISOVÁ, Eva. Tajemství zlatého kličku: Loutková hra o 3 dějstvích. Praha: Orbis, 1959. 81, [3] s. Hry pro loutky; Sv. 46.

\section{Книжные издания}

Первый перевод книги о Буратино А. Толстого на чешский язык вышел в 1937 году в издательстве «Melantrich», автором перевода был Петр Денк - переводчик и автор, благодаря которому кчешскому читателю попадали сказки не только русского происхождения (Новакова, 54). Его перевод был первым, и затем он два раза переиздавался в новом, государственном и практически монополизированном издательстве «Státní nakladatelství dětské knihy» в 1950 (15000 экземпляров) и 1954 (35 000 экземпяров) годах. Интересен факт, что упомянутое издание соответствует первому польскому и российскому изданию, так как во всех использованы иллюстрации Б. Малаховского.

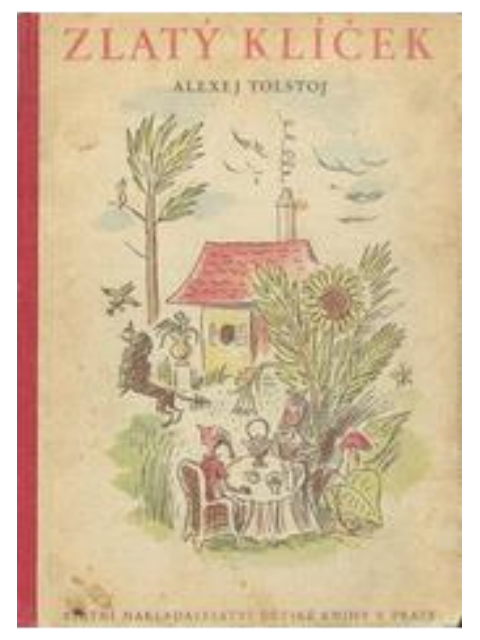

Иллюстрации того же художника использовались ив издании 1959 года, в основе которого лежал уже новый перевод Ганы Врбовой. Издательством третьего выпуска книги на чешском было в 1959 году издательство «Svět sovětů», напечатавшее 20000 экземпляров.

Рисунок 10 - Обложка издания: TOLSTOJ, Aleksej Nikolajevič. Zlatý klíček aneb Buratinova dobrodružství. 2. vyd., 1. vyd. ve SNDK. Praha: SNDK, 1950.

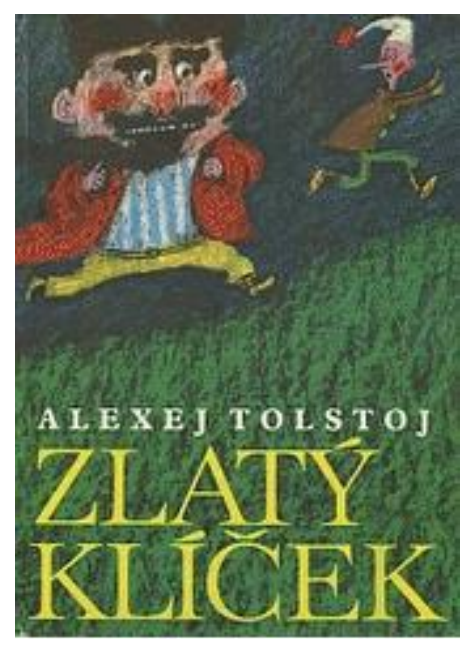

Новое художественное оформление книги появилось в издательстве «Lidové nakladatelství» в 1970 году. Тираж составил 50000 экземпляров, и художником стал Ян Черны.

Рисунок 11 - Обложка издания: TOLSTOJ, Aleksej Nikolajevič. Zlatý kliček aneb Buratinova dobrodružství. 4. vyd., (v Lid. nakl. 1. vyd.). Praha: Lidové nakladatelství, 1970. 120, [5] s. 


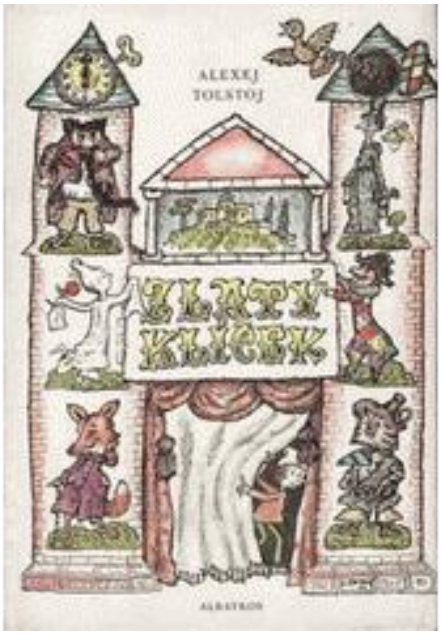

В 1979 году было напечатано 23000 экземпляров уже раннее изданного перевода Ганы Врбовой, и были использованы прежние иллюстрации Яна Черного. Изменена была лишь обложка (см. рисунок выше).

Рисунок 12 - Обложка издания: TOLSTOJ, Aleksej Nikolajevič. Zlatý kliček aneb Buratinova dobrodružství. 5. vyd. Praha: Albatros, 1979.

В чешском издании «Золотого ключика» 2013 года на первой странице указано «По мотивам оригинальной истории Алексея Толстого пересказала Гордана Малетич» (перевод ЕКМ). В тираже книги указано, что авторские права принадлежат сербской фирме «IKP EVRO/GIUNTI», права на текст - Г. Малетич. Далее указаны: чешский издатель «Fortuna Libri» как обладатель прав на чешское издание и чешский переводчик Петр Шварц. Указано также название оргинала - «Golden Кеу», по которому можно предположить, что перевод, возможно, сделан с английского оригинала. В любом случае, проанализировав данное чешское издание, мы можем заключить, что текст является выхолощением сюжета А. Толстого. Об этом свидетельствует объем текста,

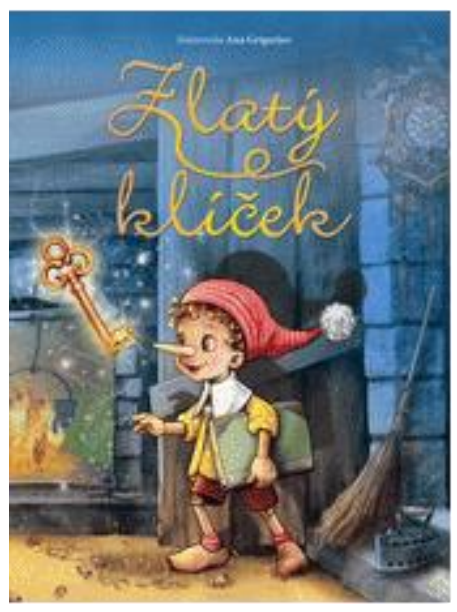
который был сжат до 62 страниц (на всех страницах над текстом доминируют иллюстрации, в среднем на одной странице размещено 7 строчек).

Таким образом, о данном издании можно говорить как об одной из многих современных адаптаций, которые достаточно свободно обращаются с оригиналом и раздвигают возрастные границы, т. е. приближают произведение к читателям младшего школьного возраста или даже дошкольникам. Больше об этой тенденции см. ниже.

Рисунок 13 - Обложка издания: MALETIĆ, Gordana a Aleksej Nikolajevič TOLSTOJ. Zlatý klíček. 1. vyd. Ilustroval Ana GRIGORJEV. Praha: Fortuna Libri, c2013. Fortuna Junior. ISBN 978-80-7321-704-4. 


\section{Сравнительный анализ чешских переводов}

В данной монографии немалое внимание уделено переводу и стратегиям перевода собственных имен (см. выше). В данном контексте в таблице ниже приводятся переводческие решения в двух переводах текста А. Толстого о Буратино и соответствующее решение из самого издаваемого перевода текста К. Коллоди о Пиноккио на чешском языке.

\begin{tabular}{|c|c|c|c|}
\hline А. Толстой в оригинале & $\begin{array}{c}\text { А. Толстой в переводе } \\
\text { П. Денка } \\
\text { (изд. } 1954 \text { г.) }\end{array}$ & $\begin{array}{c}\text { А. Толстойв переводе } \\
\text { Г. Врбовой } \\
\text { (изд. } 1970 \text { г.) }\end{array}$ & $\begin{array}{c}\text { К. Коллоди - перевод } \\
\text { М. и Я. Голицких } \\
\text { (изд. } 1969 \text { г.) }\end{array}$ \\
\hline Крыса Шушара & krysa Šušara & krysa Šušara & - \\
\hline Папа Карло & otec Karlo & otec Karlo & kmotr Geppetto; Kašička \\
\hline Буратино & Buratino & Buratino & Pinocchio \\
\hline $\begin{array}{l}\text { Говорящий Сверчок; } \\
\text { Букашка-таракашка }\end{array}$ & $\begin{array}{l}\text { Mluvící cvrček; } \\
\text { stoleté broučisko, } \\
\text { cvrčisko }\end{array}$ & $\begin{array}{l}\text { Mluvící cvrček; } \\
\text { stoletý brouku pabouku }\end{array}$ & $\begin{array}{l}\text { mluvící cvrček; } \\
\text { odporný cvrčoune }\end{array}$ \\
\hline Джузеппе & Džuzeppe & $\begin{array}{l}\text { Giuseppe řečený } \\
\text { Modronoska }\end{array}$ & $\begin{array}{l}\text { mistr Antonio; } \\
\text { mistr Třešnička }\end{array}$ \\
\hline Мальвина & $\begin{array}{l}\text { Panenka s blankytnými } \\
\text { vlásky }\end{array}$ & $\begin{array}{l}\text { Holčička s modrými } \\
\text { vlásky; Malvína }\end{array}$ & víla Modrovláska \\
\hline Карабас Барабас & siňor Karabas Barabas & signore Karabas Barabas & loutkář Ohňojed \\
\hline Лиса Алиса & liška Eliška & liška Alisa & lišák \\
\hline Кот Базилио & kocour Bazilio & kocour Basilio & koucour \\
\hline $\begin{array}{l}\text { Дуремар } \\
\text { (продавец лечебных } \\
\text { пиявок) }\end{array}$ & $\begin{array}{l}\text { Duremar } \\
\text { (prodavač léčivých } \\
\text { pijavic) }\end{array}$ & $\begin{array}{l}\text { Duremar, } \\
\text { prodavač pijavek }\end{array}$ & - \\
\hline Пудель Артемен & pudl Artěmon & pudlík Artemon & pudlík Pozor \\
\hline Черепаха Тортилла & želva Tortila & želva Tortila & - \\
\hline Арлекин и Пьеро & Pierot a Harlekýn & Pierot a Harlekýn & Šašek a Kašpárek \\
\hline
\end{tabular}

Таблица 7 - Сравнение собственных имен в русском оригинале Толстого и чешских переводах 
На основе проведенного анализа можно заключить, что разница между двумя чешскими вариантами перевода А. Толстого незначительная - чаще всего переводчица Г. Врбова заменяла фонетический принцип записи собственных имен (характерный для русского оригинала) орфографией, максимально приближенной к итальянскому оригиналу (характерно для чешской традиции) - ср. в таблице выше: siňor/ signore; Bazilio/ Basilio; Artěmon/Artemon; Džuzeppe/ Giuseppe. В остальном можно констатировать, что оба чешских переводчика Толстого выполнили свою работу очень хорошо, и качество перевода нельзя считать причиной того, что перевод в наше время в Чехии не переиздается.

\section{Современные тенденции}

Вышеприведенный факт подтверждает, например, судьба другого русского переложения в чешском контексте. После 1989 года не переиздается «Волшебник Изумрудного города» А. Волкова (на чешском: Kouzelník ze Smaragdového města), а лишь переводы с английского оригинала Ф. Л. Баума (на чешском: Čaroděj ze země $\mathrm{Oz})$.

Более развернутый анализ современного чешского восприятия русской детской литературы дается в отдельной монографии (Кудрявцева Маленова 2017), в рамках данной главы ограничимся лишь суммированием итогов:

- после 1989 года в Чехии русская детская литература (за редкими исключениями) не переиздается, и новые переводы возникают лишь изредка

- особое место среди чешских современных изданий или переизданий (переводов с русского языка в области детской литературы) занимают тексты русских сказок; при этом традиционно уделяется внимание русским народным сказкам (многочисленные книжные издания даже после 1989; культовым среди чехов стал фильм-сказка «Морозко» ипод его воздействием возникают другие формы, например, спектакли, ледовое шоу ит. д.

- с 90-х гг. появляется паразитирующая на успешных мультфильмах массовая книжная продукция («Ну, погоди», «Маша и Медведь»)

- в Чехии переведены книги современных русскоязычных писателей стиля фентези (С. Лукьяненко, Н. Щерба)

- с 90-х годов заметна тенденция публиковать на чешском проверенные временем произведения; это и возвращенные переводы авторов, исчезнувших с чешского книжного рынка после 1948 года (Л. Чарская) или 
авторов, переведенных не полностью (Д. Хармс), или недоступную чешскому читателю русскую классику (А. Погорельский)

- самыми многочисленными современными изданиями из области русской детской литературы является однозначно трилогия Н. Носова о Незнайке; переводы М. Корейса не перестали переиздавать даже после переломного 1989 года $^{27}$ с прежними чешскими иллюстрациями и графическим оформлением

- часто появляются переиздания книг с иллюстрации известных и успешных чешских иллюстраторов - текст в таком случае либо переиздается сминимальными изменениями («Доктор Айболит» К. Чуковского переиздавался в 1996 и в 2014 гг. с иллюстрациями Йосефа Лады, в переводе Раисы Новотной 1946 года), либо текст заново переводится новым, как правило неизвестным, переводчиком (сборник И. Карнауховой «Красота ненаглядная» приобрел на чешском языке популярность уже в 60-70е гг. 20 века не без успеха иллюстраций К. Фиалы, явно вдохновленного Билибиным; данный сборник был переиздан в 2010 году в том же графическом оформлении Фиалы, но в новом переводе К. Вартанян), либо текст прежнего перевода маскируется переформатированием (сказка Л. Н. Толстого «Три медведя» публиковалась на чешском языке с 1961 года с иллюстрациями известной чешской художницы Г. Зматликовой; сын (и наследник авторских прав) художницы выпустил под своим именем переиздания в 2002 и в 2014 году. В них добавлены места для детского творчества - счет, раскраска и т. д. Однако, в основе лежит текст перевода Э. Долейшовой и имя Л. Н. Толстого переместилось с обложки на разворот книги).

На основе вышеприведенных примеров, основанных на подробных анализах (Кудрявцева Маленова, 2017), можно прийти к заключению, что (не)существование некоторых произведений русской детской литературы в Чехии нельзя относить лишь к качеству текстов. Большую роль в (не)восприятии русской детской литературы играют внелитературные факторы - экономические, идеологические, время перевода, художественное оформление и т. д.

\footnotetext{
27 Можно сравнить годы изданий первого тома «Приключения Незнайки и его друзей»: 1957, 1958, $1961,1969,1972,1977,1984,1996,2003,2009,2014$. Больше об этом феномене (Кудрявцева Маленова 2018, 83-94.
} 


\title{
La fiaba letteraria russa in Italia: traduzione e ricezione - Русская литературная сказка в Италии
}

\author{
(Джулия Де Флорио)
}

"Folktale", "fairy tale", "household tale", "märchen", "conte populaire" e, per restare in Italia, "favoletta", "novellina", "cincella": il termine skazka è piuttosto complesso. Senza approfondire l'articolata catalogazione dei testi che possono rientrare nella categoria skazka ci limitiamo a evidenziare i due traducenti più spesso utilizzati in italiano: "favola" e "fiaba". I dizionari riportano spiegazioni sommarie della differenza tra i due: "La fiaba si distingue dalla favola (v.), inquantoché in essa non solo non può esistere assolutamente un fine morale, ma neppure gli animali compaiono necessariamente e con caratteri precisi e ben determinati; dalla saga, in quanto non è legata ad avvenimenti, a luoghi e a tempi determinati; e dalla novella, inquantoché da essa esula ogni intenzione realistica. 'Nulla contrasta più con lo spirito della fiaba che un fato morale, una relazione necessaria' (Novalis)"28 La favola invece è una "breve narrazione per lo più in versi. Quando si parla di f. come genere letterario, ci si riferisce comunemente a quella i cui caratteri fondamentali furono segnati già da Esopo e universalmente diffusi da Fedro: essenziale è che essa racchiuda una verità morale o un insegnamento di saggezza pratica e che vi agiscano (a volte insieme a uomini e dei) animali o esseri inanimati, sempre però tipizzazioni e quasi stilizzazioni di virtù e di vizi umani. Da notare però che l'animale perde talvolta, e sempre più frequentemente quanto più ci si avvicina ai tempi moderni, ogni caratterizzazione psicologica peculiare, diventando semplice pretesto per introdurre la conclusione morale. [...] Possibile invece, e necessario, distinguere la f. dalla fiaba anche se il confine tra esse è incerto, tanto che le due parole sono talvolta impropriamente usate l'una invece dell'altra"29. Per sommi capi dunque la "favola" parrebbe essere una sottocategoria della fiaba - ovvero la cosiddetta "fiaba di animali" - caratterizzata da una morale; Gianfranco d'Aronco definisce "favola" un termine "strettamente legato alla tradizione esopiana"30.

Per questo motivo negli anni si sono riscontrati problemi traduttivi e relativi fraintendimenti interpretativi. A ciò si aggiunge le modifiche che ha subito nel tempo la lingua italiana per cui termini come "favolelli", o "novelline" ${ }^{31}$, inizialmente utilizzati, sono stati abbandonati a partire dalla seconda metà del Novecento. Evidenziamo anche la

\footnotetext{
${ }^{28}$ http://www.treccani.it/enciclopedia/fiaba.

${ }^{29} \mathrm{http}: / /$ www.treccani.it/enciclopedia/favola. [corsivo mio]

${ }^{30}$ G. D'Aronco, Indice delle fiabe toscane, op. cit., p. 11.

${ }^{31}$ Si pensi alle Novelline popolari italiane di Domenico Comparetti o ai Favolelli di Krylov tradotti da Mary Tibaldi Chiesa. In effetti lo studioso Stith Thompson avvicina il termine "folktale" all'italiano "novella" (e non favola o fiaba). Cfr. S. Thompson, La fiaba nella tradizione popolare, op. cit., p. 24.
} 
mancanza nella lingua italiana di un traducente univoco per il russo "basnja". I testi di Krylov o Esopo, per rimanere a una tradizione più vicina a quella italiana, sono perciò tradotti come "favole", con la variante, oggi desueta, di "favolelli". Da questo punto di vista se analizziamo i titoli del corpus di fiabe raccolto per la presente indagine si possono osservare alcune incongruenze: in Le fiabe per la mia bambina (Skazki dlja moej devočki) di Mamin-Sibirjak, i protagonisti sono animali perciò sarebbe più preciso tradurre come favole; non solo: nella traduzione dell'introduzione di Andrej Černyšev in punti diversi si usano, indistintamente, "fiabe" e "favole"32. Un altro esempio: Skazki di Puškin sono spesso tradotte come "fiabe", ma non sono poche le edizioni in cui vengono definite "favole"33; ancora, Russkie satiričeskie skazki della sopracitata raccolta di Moldavskij diventano, all'interno della prefazione, sia "fiabe" sia "favole ${ }^{34}$. È difficile individuare la motivazione di tali divergenze traduttive; si può ipotizzare, soprattutto in mancanza di note o commenti esplicativi, che alla base ci sia una scelta editoriale oppure una "disattenzione" nel privilegiare uno dei due termini rispetto all'altro.

La "basnja" di Krylov pone invece un problema diverso, se cioè si possano considerare a buon diritto favole letterarie, ovvero di un autore ben preciso, o rielaborazioni - anche molto distanti dal testo di partenza - di favole già esistenti, in particolar modo di Esopo e La Fontaine. Gli studi sui testi kryloviani mostrano un'ampia gamma di approcci: dalla traduzione quasi pedissequa all'imitazione e all'adattamento. A volte Krylov coglie l'idea dominante e modifica il resto della favola; ma seppur egli debba molto alla tradizione favolistica occidentale gli studiosi sono unanimi nel tributargli il grande merito di aver posto solide basi alla tradizione favolistica russa ${ }^{35}$, aggiungendovi una nota di amarezza celata dietro un leggero umorismo.

Lasciando da parte il caso di Krylov, le prime favole letterarie russe tradotte in lingua italiana sono quelle di Žukovskij, Mamin-Sibirjak e Puškin. Quest'ultimo in particolare si ripresenta in molteplici edizioni, a partire dagli anni Quaranta ed è l'autore di fiabe che frequenta con maggiore assiduità il mercato editoriale italiano, nonostante le

\footnotetext{
32 D. Mamin-Sibirjak, Fiabe per la mia bambina, trad. di A. Montingelli, ill. di G. Judin, Mosca, Progress, 1982, pp. 5-7.

${ }^{33}$ Per l'analisi di queste opere di Puškin si veda il paragrafo 2.3.

${ }^{34}$ II titolo è Fiabe satiriche russe, ma nella nota finale si legge: "Il volume Russkaja satiričeskaja skazka (La favola satirica russa) pubblicato a Mosca nel 1958 da D.M. Moldavskij [...] II protagonista della favola satirica è un contadino povero [...] A differenza della favola fantastica, dove l'azione si svolge 'in un regno lontano', I personaggi della favola satirica agiscono in un ambiente reale". Fiabe satiriche russe, dalla raccolta di D.M. Moldavskij, op. cit., pp. 151-155.

35 "Pertanto, Krylov può essere considerato il vero creatore della favola russa, poiché non si contentò della traduzione o imitazione di favole straniere (La Fontaine, Florian, Esopo ecc.) ma, nel corso della sua evoluzione, passò a scrivere favole prettamente russe, di grande originalità e bellezza". I. Krylov, Cento favole, trad. di N. Martini Bernardi, litografie di P. Annigoni, Parma, Guanda, 1961, p. 195. Cfr. V. Kenevič, Primečanija k basnjam Krylova, Sankt-Peterburg, Tip. Imperatorskoj akademii nauk, 1878, pp. V-XVIII.
} 
difficoltà traduttive che impone. Come per le fiabe popolari il periodo di maggiore successo della fiaba letteraria si registra negli anni Settanta e Ottanta in cui, seppur in numero ridotto, fanno il loro ingresso in scena i maggiori classici della letteratura per l'infanzia russa del Novecento: Kornej Čukovskij, Samuil Maršak, Sergej Michalkov.

\section{Le fiabe in versi di Kornej Čukovskij, Samuil Maršak, Sergej Michalkov}

II più tradotto dei tre è Kornej Čukovskij, nonostante le molte difficoltà a livello di ritmo, intonazione, metro e intertestualità che presentano le sue favole in versi ${ }^{36}$. Dopo la pubblicazione del Dottor Aibolit nel paese delle scimmie del 1970 esce nel 1974 una raccolta che contiene alcune tra le sue più famose favole in versi: II telefono, Mifamale, Mangiasporco e /l sole rubato ${ }^{37}$. Mangiasporco e // sole rubato riappaiono in volumi a se stanti rispettivamente nel 1978 (edizioni Progress) e nel 1985 (edizioni Malyš), il primo con la stessa traduzione di M. Cozza-Zoubok, il secondo in una nuova versione di Saverio Reggio $^{38}$. Il grande narratore di storie è tornato molto recentemente nel mercato editoriale italiano con una nuova tradizione/adattamento de // telefono, a cura di M. Di Leo $^{39}$.

Le due traduzioni de // telefono si differenziano molto: la prima, di Margherita Cozza Zoubok, è più vicina al testo di Čukovskij e riprende la scansione in sequenza dell'originale, mentre quella di Atmosphere è a tutti gli effetti un adattamento, come riportato nel titolo. Si tratta in effetti di una riscrittura in cui rimane la struttura narrativa originale (una serie di animali che telefona alla voce narrante con richieste, spesso assurde), ma riveduta, con meno animali protagonisti e descrizioni che a volte si discostano dall'originale.

Inoltre è chiaro fin dalla prima pagina l'intento di far risaltare l'immagine rispetto alle parole; il nome dell'illustratrice è scritto per primo e in caratteri più grandi. Il testo, posto su doppia facciata, è sempre intervallato da una doppia pagina illustrata.

\footnotetext{
${ }^{36}$ Sul Čukovskij favolista esistono molti studi anche se pochi riguardano l'aspetto formale delle sue favole. Cfr. B.M. Gasparov, I.A. Paperno, "Krokodil K.I. Čukovskogo: k rekonstrukcii ritmiko-semantičeskich alljuzij", Tezisy I Vsesojuznoj konferencii "Tvorčestvo A.A. Bloka i russkaja kul'tura XX veka”, Tartu, 1975; I.V. Kondakov, "Lepye nelepicy Korneja Čukovskogo: tekst, kontekst, intertekst", Obščestvennye nauki I sovremennosti, 1, 2003, pp. 158-176. Si vedano anche: M. Petrovskij, Kniga o Kornee Čukovskom, Moskva, Sovetskij pisatel', 1966; i commenti di Elena Cesarevna Čukovskaja al primo volume dell'opera completa in 15 volumi: K.I. Čukovskij, Sobranie sočinenij v 15-i tomach, Moskva, Terra - Knižnyj klub, 2001-2013, pp. 572-593.

${ }^{37}$ K. Čukovskij, II libro delle meraviglie, trad. di M. Cozza-Zoubok, disegni di V. Konascevic [II telefono], V. Suteiev [Mifamale], A. Kanevski [Mangiasporco], Ju. Vasnetsov [I/ sole rubato], Mosca, Progress, 1974.

${ }^{38}$ Del 1981 è invece la traduzione di /l pulcino per Malyš-Edest. K. Cukovskij, Il pulcino, trad. di S. Reggio, ill. di T. Sevariova, Mosca-Genova, Malyš-Edest, 1981.

${ }^{39}$ K. Čukovskij, Il telefono, adattamento di M. Di Leo, ill. di A. Papini, Roma, Atmosphere Libri, 2017.
} 
Anche de // sole rubato esistono attualmente due versioni, la prima contenuta nel libro curato da Margherita Cozza Zoubok e la seconda, nella traduzione di Saverio Reggio, per Malyš-Edest (1985) in versione pop-up. Entrambe le traduzioni fanno uso di metri diversi - in prevalenza ottonari, novenari e decasillabi. La ripartizione strofica segue, quasi sempre, quella dell'originale, con alcune eccezioni.

È interessante rilevare che la traduzione che cerca di trovare un maggiore equilibrio tra il significato e la struttura ritmico-metrica è quella cronologicamente più datata, cioè del 1974. La versione di Reggio invece è meno attenta al ritmo impareggiabile - delle fiabe di Čukovskij e rimane più legata alla descrizione degli episodi che alla loro trasposizione creativa in un altro sistema linguistico e culturale.

II risultato migliore a livello di riproposizione del complesso sistema sonoro e semantico è raggiunto in Lavamano (Mojdodyr), anche se è la traduzione che più si discosta dalla favola originale, di cui perde alcune importati caratteristiche: la stilizzazione del tono epico, da bylina, che attua Čukovskij nel raccontare le peripezie del piccolo protagonista alle prese con il "Comandante delle spugne" non trova una corrispondenza nella versione italiana, seppure rimane traccia del ritmo incalzante dell'inseguimento. Scompaiono i riferimenti alla topografia di San Pietroburgo - il fiume Mojka e Tavričeskij sad, via Sadovaja e Sennaja - e le ripetizioni, vero e proprio coro tragico greco che accompagna la voce del protagonista, subiscono forti modifiche. A volte le strofe in traduzione ricevono ulteriori significati per aumentare la sonorità della poesia e la forza espressiva della scena evocata.

Nella favola Mifamale alcune ripetizioni vengono mantenute e anzi sottolineate dalla diversa disposizione, anaforica, rispetto all'originale, mentre altre si perdono nel passaggio all'italiano. Infine il traduttore a volte arriva a delle soluzioni "di compromesso", cercando di mantenere il complesso disegno sonoro dell'originale pur modificando - in base anche al significato - il numero e tipo di ripetizioni e assonanze:

Molteplici sono dunque le difficoltà che si incontrano quando si cerca di tradurre poesia per l'infanzia; in particolare, le favole di Čukovskij sono poesie che rielaborano in maniera originale il grande patrimonio del folklore russo e inglese (dalla bylina alla conta, dalla "draznilka" alla "nebylica" o "topsy-turvy rhyme"), inserendo, a livello formale, le innovazioni linguistiche - di metro, di ritmo, di intonazione - che in quegli anni portano avanti Majakovskij, Kručenych, Chlebnikov e molti altri poeti della cosiddetta avanguardia, ma senza dimenticare la lezione della poesia d'argento, dei simbolisti e degli acmeisti. Per questo motivo la traduzione di opere all'apparenza così semplici, in quanto destinate a giovani lettori, ma in realtà estremamente stratificate, diventa una sfida che pochi al momento hanno raccolto. Sono del tutto assenti infatti traduzioni di alcuni 
capolavori quali Krokodil, Mucha-Cokotucha, Tarakanišče, Fedorino gore, per citare i più famosi.

Più ristretta ancora è la conoscenza dei lettori italiani dell'opera di Samuil Maršak, presente in italiano con due soli titoli: Animali in gabbia del 1980 e Favola del topino sciocco del 1983. Il primo non è propriamente una favola, anche se si inserisce in una tradizione di racconti e storie che hanno al centro gli animali ${ }^{40}$. Due differenze saltano subito agli occhi: nella versione italiana il libro è diventato un pop-up, come la maggior parte delle uscite di Malyš-Edest degli anni Settanta e Ottanta, per cui il peso semantico è spostato più sull'immagine, tridimensionale, che sul testo, che serve quasi da cornice alla dominante parte visuale. In secondo luogo manca tutta la parte introduttiva della vicenda che ambienta la storia nello zoo; la parte introduttiva, composta da numerose strofe, non è tradotta. Mancano anche molti animali/episodi, per esempio gli orsi bianchi, il canguro o il cigno, ma la ragione potrebbe essere la versione originale di riferimento, in quanto ne erano state pubblicate diverse dagli anni Venti in poi.

La tetrapodia trocaica dell'originale viene sostituita da metri italiani variabili - in prevalenza novenari ed endecasillabi. Lo schema delle rime è pressoché invariato: nella versione russa le rime prevalenti sono baciate con alcune rime incrociate; nella versione italiana sono tutte baciate.

La straordinaria abilità di Maršak di tratteggiare in pochi, brevi, versi una situazione o un comportamento rende molto difficile la traduzione dei testi che spesso omettono alcuni precisi dettagli, come per esempio le zampe callose del cammello o il fatto che i due pinguini siano fratelli. Le descrizioni risultano comunque divertenti e sono un buon supporto alle immagini che catturano con maggior facilità l'attenzione dei lettori più piccoli.

La Favola del topolino sciocco in versione italiana perde molto del fascino dell'originale: le ripetizioni e le rime elementari che danno il ritmo di una ninna nanna, svolgendo la trama per brevi episodi, si perde in una serie di quartine in cui quasi mai si ravvisa uno schema metrico e rimico preciso. Si mantengono invece le ripetizioni tra le varie strofe che nell'originale sono ormai diventate proverbiali: “Pobežala myška-mat', / Stala [...] v njan'ki zvat'", con il nome dell'animale che viene chiamato di volta in volta dalla madre per far addormentare il topolino sciocco. Non si mantiene invece la rima che

\footnotetext{
${ }^{40}$ Detki v kletke esce nel 1923 per la casa editrice Raduga. II tema degli animali in gabbia e degli zoo percorre tutti gli anni Venti della letteratura russa per l'infanzia e va ben oltre: pensiamo a Čto ni stranica to slon, to l'vica di V. Majakovskij, My v zooparke di A. Barto, Mnogo zverej di A. Vvedenskij, Zoologičeskij sad di S. Fedorčenko fino al ciclo di racconti Pitomcy zooparka di V. Čaplina che occupa l'autrice per quasi quarant'anni e diventa un classico del genere tradotto in moltissime lingue. È necessario citare anche Zverinec di Chlebnikov, scritta prima del 1917 e per un pubblico adulto, ma che pone al centro il tema degli animali e dell'infanzia.
} 
contraddistingue il primo, secondo e il quarto verso della quartina in russo. II ritmo tranquillo ma deciso della storia prepara al climax finale in cui si coglie tutto il sottile umorismo di Maršak che conclude la vicenda con la terribile punizione riservata al protagonista per non essersi saputo accontentare. L'assenza di rime e metri ripetuti ostacola una lettura partecipata e coinvolgente che invece è il fulcro di questo genere: non si dà poesia per l'infanzia che non possa essere letta ad alta voce; per il pubblico prediletto da Maršak, ovvero i bambini in età prescolare, il momento a tu per tu con il libro è infatti quasi nullo, le parole arrivano sempre prima all'orecchio e l'occhio semmai si sofferma sulle illustrazioni che accompagnano il testo. Perciò la sonorità è così importante ed è già presente nei giochi e nelle canzoni dei bambini; la poesia ha il compito di riprodurla, di alimentare nei più piccoli quella "potenza unita all'eleganza, alla leggerezza, alla naturalezza, all'allegria, alla sobrietà" ${ }^{41}$, elemento fondante la parola artistica. Anche per Čukovskij, come per tutti i maggiori poeti per l'infanzia, la possibilità di contare su una lettura ad alta voce e collettiva si configura come elemento fondamentale: “Quando scrivo - confessava Čukovskij - mi immagino sul palco di fronte a una moltitudine di ascoltatori" ${ }^{42}$.

Un altro autore ancora da svelare al pubblico italiano è Sergej Michalkov, il padre del celeberrimo Djadja Stepa: a distanza di un anno, nel 1986 e nel 1987, escono due raccolte di fiabe scritte da Michalkov, entrambe curate da Irina Zaslavskaja e Marika Marchese. I libretti hanno l'aspetto di opere occasionali: sono edite rispettivamente da Prova d'Autore e Lunarionuovo, due progetti editoriali che fanno capo a Mario Grasso, scrittore siciliano e attivo operatore culturale ai tempi dell'Unione Sovietica. Della collaborazione con I'URSS ne è prova uno scatto che ritrae presso la Segreteria dell'Unione Scrittori dell'Unione Sovietica nell'ottobre 1986 Jurij Voronov (ministro per l'istruzione e direttore della "Literaturnaja Gazeta") e Mario Grasso, nella qualità di direttore di Lunarionuovo, nell'atto di firmare il protocollo di accordi culturali per la redazione della rivista a Mosca e lo scambio di collaborazioni letterarie. Nella fotografia compaiono anche Sergej Michalkov e Afanasij Veselickij ${ }^{43}$. La selezione di poesie di Fiabe in versi è particolare, soprattutto in base al titolo che annuncia che si tratta di Fiabe come effettivamente il poeta ha scritto per i più piccoli. Nell'ultima pagina si dice che il libro contiene fiabe in versi scritte tra il 1935 e il 1978. Le "basnja" sono però alternate a poesie del ciclo sulla guerra, come Frontovaja muza (La musa del fronte) e ad altre poesie "d'occasione", per esempio Una cosa ignorata dall'Aeroflot.

\footnotetext{
${ }^{41}$ B.E. Galanov, I.S. Maršak, Z.S. Papernyj, Ja dumal, čustvoval, ja žil. Vospominanija o Samuile Maršake, Moskva, Sovetskij pisatel', 1988, pp. 430-431.

${ }^{42}$ S.I. Sivokon', Uroki detskich klassikov, Moskva, Detskaja literatura, 1990, p. 44.

${ }^{43}$ Si può consultare la fotografia al seguente link:

http://www.mariograssoscrittore.it/index.php?option=com_content\&view=article\&id=52\&ltemid=67.
} 
Dal confronto tra l'originale e la traduzione italiana si intuisce subito che i libri non sono affatto pensati per un pubblico di bambini; il lessico tende a seguire un registro più alto di quello dell'originale ("sciabordano gli oceani", "imperversa un temporale"); non c'è quasi mai un tentativo di riprodurre, se non proprio la metrica, almeno l'intonazione e la struttura ritmico-fonetica del russo. Le poesie in traduzione hanno perciò l'andamento della prosa più che della poesia e si concentrano sulla riproduzione "fedele" del significato $^{44}$, lasciando da parte il lato sonoro delle composizioni. Nonostante la presenza di alcune "basnja" è quindi difficile considerare questo libro una presentazione delle opere per l'infanzia di Michalkov, e in questo senso il titolo appare fuorviante.

Un discorso a parte merita invece Vladimir Majakovskij che in Italia riceve una grande attenzione se ci riferiamo alla lirica civile e, parzialmente, amorosa; le sue poesie per bambini approdano qui con tre edizioni rispettivamente del 1969, 1979 e $1984^{45}$. L'esordio di Majakovskij nel campo della letteratura per l'infanzia risale al 1925, anno in cui pubblica 14 poesie ${ }^{46}$ dai temi più svariati, ma con un medesimo lavoro sulla lingua e sulla necessità di comunicare con i bambini in un modo peculiare. Majakovskij dispiega tutto il suo ricco armamentario poetico, parla ai bambini con la stessa audacia e onestà con cui si relaziona agli adulti e non fa alcuno sconto, pur tenendo presente la specificità del destinatario, a cui si sente affine soprattutto a livello espressivo. Del pensiero infantile condivide infatti il gusto per l'iperbole, la carica di ottimismo e la dimensione utopica che porta al cambiamento effettivo della realtà nel quale Majakovskij nutre grandi speranze.

Occorre sottolineare che per la traduzione de Il cavallino di fuoco viene chiamato in causa Antonio Porta (1935-1989), importante scrittore e poeta milanese del secondo Novecento. Nella traduzione opta per l'ottonario, le strofe sono più regolari dell'originale, anche se c'è una certa varietà e si passa dalle terzine alle ottave con tutti i tipi di strofa intermedi. Moltissime sono le parole tronche per rispettare la gabbia metrico-ritmico. La punteggiatura italiana è decisamente più semplice di quella majakovskiana che fa uso di tiré, virgole e delle famosa disposizione a scaletta non riproposta in traduzione. La descrizione dettagliata del processo che porta alla costruzione del cavallo - obiettivo di Majakovskij - è riproposta nella versione di Porta, pur con molte differenze nella descrizione delle varie scene. In italiano è più difficile cogliere il ritmo incalzante che

\footnotetext{
${ }^{44}$ Da notare alcuni errori grammaticali grossolani che indicano la probabile origine occasionale del libro e la poca cura nella sua composizione: "Se caso mai l'orso sarebbe venuto / a vedere il quadro". S. Micalkov, Fiabe in versi, trad. di I. Zaslavskaja e M. Marchese, Acireale, Lunarionuovo, 1986, p. 48.

${ }^{45} \mathrm{Nel} 2006$ è stata realizzata una nuova edizione de /l cavallino di fuoco per Nugae di Genova, ma con lo stesso testo dell'edizione del 1969.

${ }^{46}$ Su Majakovskij poeta per bambini cfr.: G. De Florio, A. Niero, La ricezione della letteratura russa per I'infanzia in Italia (1900-2017), op. cit., p. 427 [nota 28].
} 
esprime a un tempo la creazione passo passo del giocattolo e il processo di scoperta del bambino che impara come si fabbricano gli oggetti.

Mantiene la regolarità formale anche la traduzione di Saverio Reggio di Immagina: un animale ad ogni pagina in versione pop-up che non dà conto delle sperimentazioni attuate da Majakovskij, per esempio a livello di rima; il metro invece è più vario, domina il decasillabo, ma sono inseriti alcuni endecasillabi e dodecasillabi e in generale la versione italiana risulta più regolare:

Più coraggiosa da questo punto di vista la resa di Aldo Canestri per Questo è bene, questo è male; egli mantiene la disposizione a scaletta e anche le illustrazioni si rifanno a un'estetica più simile a quella di Majakovskij, con il tratto espressivo, l'uso piatto del colore e forti contrasti cromatici che occhieggiano alla grafica della ROSTA. I giochi di rima tentano di riprodurre la presa di distanza dalla norma di composizione che caratterizza il lavoro sul linguaggio dei primi due decenni del Novecento e in particolare la riflessione di Majakovskij. Questo procedimento rischia però di diventare poco comprensibile all'orecchio di un bambino che potrebbe trovare difficoltà a comprendere i complessi giochi sonoro-semantici.

Anche le scelte lessicali lasciano a volte qualche dubbio: "invitto uccello" (per "groznaja ptica", uccello minaccioso, temibile) è termine di registro alto, "farò solo il benfatto" è un'espressione desueta. I riferimenti contestuali ovviamente spariscono nel passaggio alla lingua d'arrivo: gli "oktjabrjata", i "valenki" vengono omessi o sostituiti con iponimi (bambini, stivali).

Nonostante il chiaro intento di restituire tutta la complessità delle poesie per l'infanzia di Majakovskij - non a caso Čukovskij e Maršak le elogiarono molto - il testo italiano fa fatica ad adattarsi a un pubblico di piccoli lettori.

I tentativi di traduzione di questi grandi classici della poesia per l'infanzia mettono in risalto le differenze di fondo dei due sistemi linguistici; il russo è una lingua sintetica e tendenzialmente ellittica. Attraverso un uso sapiente dei casi chi compone si può permettere salti grammaticali che non corrispondono ad altrettanti vuoti logici. La mancanza di articoli e preposizioni aiuta inoltre a mantenere il verso breve e perciò più incisivo. Al contrario, l'italiano è una lingua dove la maggior parte delle parole è bisillabica o trisillabiche; nel passaggio da una all'altra l'aumento della lunghezza del verso è perciò quasi inevitabile, se non si vuole correre il rischio di creare frasi incompiute o ambigue laddove nell'originale il passaggio è chiaro e non presenta deviazioni dalla norma.

In queste traduzioni inoltre si perdono due fondamentali caratteristiche: in primo luogo la capacità di divertire il lettore, stimolandogli la fantasia o insegnandoli, senza pedanterie, nuovi concetti; secondariamente, la possibilità di mostrare nella pratica la ricchezza della lingua che stanno imparando. Per Gor'kij, primo promotore di una nuova 
letteratura per l'infanzia, il libro per l'infanzia in generale, e la poesia in particolare, "forma la lingua del bambino e perciò il suo stile deve essere severo e trasparente. Questo libro aiuta il bambino a raccapezzarsi nelle prime impressioni della vita, gli insegna il pensiero e perciò, per quanto fantastico e leggero, deve possedere una sua logica e un suo contenuto informativo. Questo libro è indissolubilmente legato al gioco del bambino. E il gioco per lui è una cosa seria" ${ }^{47}$.

Il lungo lavoro di scrittura e rifacimento delle proprie poesie per l'infanzia, testimoniato dalle innumerevoli varianti che esistono per ognuna di esse, è il frutto di queste considerazioni che i poeti calano nelle avvincenti storie pensate per i più piccoli. Tra gli autori di favole letterarie russe, in prosa, arrivate in Italia, non mancano altri celebri nomi come Aksakov, Čarušin, Garšin, Kuprin, ma il numero di traduzioni si limita sempre a uno o due volumi e nessuno di questi autori è, al momento, riuscito a entrare nel canone favolistico italiano, costituendo per lo più casi isolati a cui non è stato dato seguito sotto forma di ristampe o di altre opere tradotte. Né Gor'kij - celebre in Italia per le opere "per adulti" e in buona parte grazie alla sua lunga permanenza sulla penisola - né Boris Zachoder, il celebre traduttore di Winnie the Pooh, riescono a conquistare il mercato editoriale e a diventare nomi conosciuti del patrimonio favolistico mondiale in lingua italiana.

\section{Puškin e Tolstoj per bambini e ragazzi}

I due "casi" più interessanti dal punto di vista della ricezione di un'opera straniera nel sistema letterario italiano sono rappresentati da due grandi classici che solitamente non vengono associati in prima battuta alla letteratura per l'infanzia, né russa né straniera: Aleksandr Puškin e Lev Tolstoj.

Puškin è il primo grande autore di fiabe letterarie ${ }^{48}$; le sue opere cosiddette maggiori sono conosciute e tradotte in Italia fin dall'Ottocento ${ }^{49}$, mentre le fiabe devono aspettare gli inizi del XX secolo con due edizioni a cura rispettivamente di Verdinois (1906) e Ciampoli (1915), ma la ricezione vera e propria inizia dagli anni Quaranta del

47 Stenografičeskij otčet Pervogo vsesojuznogo s"ezda sovetsikch pisatelej, a cura di I.K. Luppol, M.M. Rozental', S.M. Tret'jakov, Moskva, 1934, p. 37.

${ }^{48}$ Cfr. A. Želanskij, Skazki Puškina v narodnom stile, Moskva, Chudožestvennaja literatura, 1936; A. Azadovskij, "Istočniki skazok Puskina”, Puškin: Vremennik Puškinskoj komissii, Moskva-Leningrad, izd. AN SSSR, 1936; A. Azadovskij, "Puškin i fol’klor”, Puškin: Vremennik Puškinskoj komissii, Moskva-Leningrad, Moskva-Leningrad, izd. AN SSSR, 1936. Per la bibliografia degli studi più recenti cfr. I. M. Kolesnickaja, "Skazki", Puškin: Itogi i problemy izučenija, Moskva-Leningrad, Nauka, 1966, pp. 437-444; altri lavori e studi successivi sono indicati negli articoli: V. E. Vacuro, "Skazka o Zolotom petuske" in Puškin: Issledovanija I materialy, S. Peterburg, Nauka, 1995, T. 15, pp. 122-133; V. Papernyj, “Opyt o 'Skazke o Zolotom petuške'", Pusškinskij sbornik, Jerusalem, Praedicta LTD, 1997, pp. 115-141.

${ }^{49} \mathrm{Nel} 1834$ compare la prima versione italiana da Puškin, II prigioniero del Caucaso, che inaugura la lunga storia della fortuna italiana del massimo poeta russo. II primo Evgenij Onegin è tradotto nel 1856, in prosa, da A. Delâtre. Cfr. C.G. De Michelis, Russia e Italia, op. cit., pp. 693-694. 
Novecento, più precisamente nel 1942 con la pubblicazione di /l gallo d'oro e altre fiabe tradotte da Tibaldi Chiesa con le illustrazioni dell'artista russo emigrato Nikulin ${ }^{51}$. Sono circa una trentina i volumi pubblicati, contenenti una raccolta o un'opera singola tra quelle composte dal poeta russo negli anni che vanno dal 1830 al $1835^{52}$. Si ripresenta anche qui il problema della scelta per il traducente di "skazka": la maggior parte delle edizioni utilizza "fiaba", ma non mancano versioni delle "favole" di Puškin ${ }^{53}$. Proseguendo in ottica traduttiva salta agli occhi la diversità tra i titoli, a volte tradotti pedissequamente, in conformità all'originale, altre volte manifestando una volontà di adattamento più forte. I due casi più interessanti da questo punto di vista sono Skazka o pope i o rabotnike ego Balde e Skazka o mërtvoj zarevne i o semi bogatyrjach: "pop", "rabotnik", "zarevna", "bogatyr" - il mondo russo si manifesta già a partire da questi realia che obbligano a scelte traduttive importanti. Così in italiano abbiamo /l pope e il servo Cetrullo; Storia del pop e del suo servo Baldà; Fiaba del pop e del suo bracciante, Gnocco; Fiaba del pope e del suo servo Baldà - tutti titoli che aprono la stessa storia. Parimenti la "carevna" e il "bogatyr" sono personaggi sconosciuti a un lettore non appassionato di mondo slavo e perciò molti traduttori hanno optato per i più generici "regina" e "cavaliere" (o "eroe") che riportano al mondo medievale col quale, peraltro, le fiabe popolari sono in stretto rapporto ${ }^{54}$.

Un'altra scelta fondamentale si trova a monte del lavoro di traduzione di queste fiabe: la resa in poesia o in prosa. È un bivio in cui si erano già ritrovati i traduttori dell'Onegin di Puškin, presente in italiano sia in versione poetica sia in riscrittura prosodica. Se chi sceglie questa seconda soluzione si inserisce nel vasto mondo della riscrittura/rielaborazione/adattamento, i temerari traduttori in versi delle fiabe di Puškin sentono invece spesso il bisogno - forse data l'autorevolezza dello scrittore in questione

\footnotetext{
${ }^{50}$ Pusckin, Il gallo d'oro e altre fiabe, trad. di M. Tibaldi Chiesa, ill. di V.P. Nicouline, Milano, Hoepli, 1942.

${ }^{51}$ Sull'arte di Vsevolod Nikulin e sul suo sodalizio con la traduttrice lombarda cfr. R. Vassena, "Tra i tesori nascosti dell'emigrazione russa: I'archivio privato di V.P. Nikulin”, Russko-ital'janskij archiv, X, pp. 275-296.

${ }^{52}$ Un primissimo problema è individuare quali opere costituiscono il corpus di fiabe puškiniane: nel 1915 Ciampoli raccoglie sotto l'etichetta "leggenda" svariate opere, precisando poi nell'introduzione: "Sotto questo nome abbiamo scelto tre generi diversi, nei quali il Puškin è stato sommo: la Ballata storica (II savio Oleg), la Ballata romantica (I fratelli masnadieri, L'annegato), la Fiaba popolare (II pescatore e il pesce, la Russalka)". A. Puškin, Drammi, poemi, leggende, trad. di D. Ciampoli, Milano, Istituto Editoriale Italiano, 1915, p. 294. De Michelis rifiuta il criterio meramente cronologico e inserisce anche Skazka o care Nikite l ego soroka dočerjach, ma esclude le fiabe incompiute, come Skazka o medvediche, o che non aderiscono pienamente al genere "fiaba", come Ženich o Pesn' o veščem Olege, che attendono più alla ballata. Cfr. A. Puškin, Fiabe in versi, trad. di C. De Michelis, Venezia, Marsilio, 1990, pp. 9-31.

${ }^{53}$ Del corpus analizzato di 30 diverse edizioni cinque usano il termine "favola".

54 "Quel sottofondo di fiaba pagana e prepagana che doveva esserci dappertutto (e che ai tempi di Apuleio prendeva paludamenti ed onomastica dalla mitologia classica) s'informò allora delle istituzioni, dell'etica, della fantasia feudal-cavalleresche (e della contaminazione religiosa cristiano-pagana di quel mondo), in qualche punto fondendosi con l'altra onda di suggestioni e trasfigurazioni, quella d'origine orientale, che s'era a sua volta propagata dal Meridione". I. Calvino, Sulla fiaba, op. cit., pp. 70-71.
} 
o la seria preparazione di chi si accinge all'impresa - di motivare il loro approccio, prima di tutto metrico e rimico. Così Verdinois rende conto del suo lavoro sul trocheo puškiniano capace di evocare un ampio ventaglio ritmico-emozionale ${ }^{55}$ : "Oltre i grandi e forti lavori, il Pusckin si provò anche a dettare novelle popolari, raccontini, fiabe, e seppe infondervi tanta vitalità, tata grazia e tanto sentimento, che la critica non esitò a chiamarli dei capilavori [sic]. Ho tentato di voltarne quattro in italiano, studiandomi di essere fedelissimo nel pensiero e nella forma. Quanto a semplicità, ho conservato, per quanto era consentito dalla natura della nostra lingua, i trapassi rapidi, i mutamenti di tempo, le ingenue ripetizioni, le espressioni non ricercate, e via discorrendo. Pel metro ho scelto l'ottonario, perché risponde al coreo dell'originale, e così pure, come nel testo, ho rimato i versi a coppie: meno però che nel Pesciolino d'oro, dove la sestina m'è parsa di andamento più conforme al racconto russo" ${ }^{56}$. Antonico riconosce l'impossibilità di un esito positivo se non molto parziale: "Presunzione già grande è stata quella di averne voluto tentare la traduzione, che, per quanto fedele al testo russo [...], è sempre un'esercitazione accademica, essendo ogni vero poeta, per intrinseca natura, intraducibile. S'è preferito, in ogni modo, usare ritmi nostrani, che ci sono sembrati i più adatti a rendere il tono favoloso e insieme ironico dell'originale: lo spirito insomma della fiaba puskiniana, che era quanto ci premeva di più salvare nella difficile impresa" ${ }^{57}$. E De Michelis motiva la scelta dell'ottonario italiano in luogo dell'originario trocheo: "Quattro delle sei Fiabe qui raccolte sono stese in tetrametri trocaici a rima baciata: tra l'impossibilità di renderle, con un dignitoso referente semantico, in una struttura metrica e rimica coerente (ancorché 'equivalente', e non 'speculare'), e la debolezza d'una resa meramente prosastica (che ne farebbe svanire un elemento essenziale), abbiamo scelto una resa che, pur rinunciando alla rima, salvaguardasse almeno un ductus di forte riconoscibilità, con una versione improntata all'ottonario italiano, pur non 'perfetto', e pur con qualche, rara, deviazione semantica. Le due fiabe restanti (nell'originale, in versi 'irregolari', e comunque senza alcun equivalente italiano) vengono date in resa prosastica" ${ }^{\prime \prime}$.

Nonostante l'autorevolezza e l'importanza del poeta russo per eccellenza nemmeno Puškin è riuscito a fuggire strane operazioni editoriali che a volte attraversano la storia della ricezione di letterature straniere. Nel 1990 infatti Mondadori pubblica II gallo d'oro e altre fiabe nella traduzione di F. Cavattoni; nel colophon del libro si legge: “Originally published in France as Le Coq d'Or in 1925 by H. Piazza. Introduction and

\footnotetext{
${ }^{55}$ Osserva Angelo Maria Ripellino: "La sagacia prosodica di Puškin sa trarre da un medesimo metro gamme di sfumature diverse". A. Puškin, Teatro e favole, trad. di T. Landolfi, Torino, Einaudi, 1961, p. XXIX.

${ }^{56}$ A. Pusckin, Le fiabe, trad. di F. Verdinois, Milano, Sonzogno, 1906, pp. 5-6.

${ }^{57}$ A. Puskin, Le fiabe, trad. di N. Antonico, Milano, Rizzoli, 1968, p. 11.

${ }^{58}$ A. Puškin, Fiabe in versi, op. cit., p. 35.
} 
English language translation". A seguire il marchio dei diritti riservati, del 1989, della casa editrice Doubleday, "a division of Bantam Doubleday Dell Publishing Group. Inc" ${ }^{59}$. Ancora più sospetto è il titolo dell'opera originale indicato in didascalia: The Golden Cockerel. Osservando questi dati l'edizione sembra a tutti gli effetti una traduzione dall'inglese, confermata anche dal traduttore che infatti lavora con il francese e l'inglese. Rimane qualche dubbio su una possibile versione originaria francese, alimentato anche dalla nota sull'illustratore Boris Zvorykin, membro del Movimento per il rinnovamento slavo in Russia. Zvorykin abbandonò la Russia dopo la Rivoluzione ed emigrò a Parigi dove collaborò con la casa editrice $\mathrm{H}$. Piazza, continuando a illustrare fiabe russe. Anche l'introduzione, a firma di Rudolf Nureyev del 1988 (probabilmente della versione francese o inglese), sembra motivata più dalla fama del geniale ballerino russo che dalla sua effettiva competenza in materia di fiabe puškiniane ${ }^{60}$. Prova ne è la presentazione fuorviante delle opere come rielaborazione del patrimonio folklorico russo attraverso i racconti della njanja, quando invece, delle fiabe di cui Puškin è autore, due derivano dai racconti della njanja, tre sono dei Grimm, una è tratta da Čulkov e una da Irving: "Bisogna quindi tenere ben distinte le benemerenze di Puskin come uno dei primi registratori di fiabe russe e il senso, il valore e le finalità delle sue 'fiabe in versi'" ${ }^{\prime 61}$.

Una strana scelta editoriale, dunque, ancor più sorprendente se si pensa che viene realizzata da una seria e importante casa editrice come Mondadori e nel 1990, quando cioè l'abitudine di tradurre letteratura russa passando da un'altra lingua (soprattutto dal francese), era ormai scomparsa. Dal confronto tra le molteplici edizioni delle fiabe - in cui domina quantitativamente la fiaba sul pescatore e il pesciolino, seguita da quella sulla magica statua del galletto e dalla storia dello zar Saltan ${ }^{62}$ - possiamo infine trarre un'ulteriore conclusione: la storia della ricezione delle fiabe di Puškin in Italia sembra seguire un doppio binario. Da un lato questa produzione viene ripensata per bambini (al contrario delle intenzioni dell'autore stesso ${ }^{63}$ ), ed è quindi oggetto di numerosi adattamenti, rifacimenti e riscritture, pubblicata in edizioni e da case editrici legate al

\footnotetext{
${ }^{59}$ A. Puškin, Il gallo d’oro e altre fiabe, ill. di B. Zvorykin, trad. di F. Cavattoni, Milano, Mondadori, 1990.

${ }^{60}$ L'introduzione immortala Puškin come eroe romantico, intriso di ideali di libertà e grande conoscitore e appassionato cultore della Francia. Nurejev racconta la sua biografia, con molte imprecisioni e osservazioni superficiali. Si sofferma, ovviamente, sui rapporti tra Puškin e la danza e i forti legami della danza russa con quella francese (altro motivo che fa pensare a una prima edizione francese del volume), ricordando che Il pesciolino d'oro era diventato un balletto di Djagilev.

${ }^{61}$ Cfr. A. Puškin, Fiabe in versi, op. cit., pp. 10-11.

${ }^{62}$ Anche per queste fiabe, per l'ultima in particolare, i titoli italiani sono molti, dal semplice Fiaba dello zar Saltan al Fiaba dello zar Saltan, di suo figlio il famoso e possente bogatyr principe Gvidon Saltanovič e della bellissima zarevna-cigno passando per molte altre varianti.

${ }^{63}$ Per una riflessione sulla concezione puškiniana di skazka si veda: M. Pljuchanova, "Le fiabe di Puškin e Angelo Maria Ripellino", Puškin, la sua epoca e l'Italia. Atti del convegno internazionale di studi, Roma 2123 ottobre 1999, a cura di P. Buoncristiano, Roma, Rubbettino, 2001, pp. 115-126. In particolare pp. 118119 e 121-122.
} 
mondo dell'infanzia. A questo tipo appartengono, per esempio, /l pesciolino d'oro di Fabbri e AMZ oppure le Fiabe e leggende pubblicate da Fabbri nella collana "Letture giovani per la scuola elementare" e corredate da un'appendice didattica con schede di comprensione, esercizi, una Nota per insegnanti e genitori e un approfondimento tematico "per conoscere la Russia" ${ }^{64}$. Non sembra invece legata a scopi didattici e divulgativi, ma a puri fini commerciali l'ultima uscita che contiene fiabe di Puškin, questa volta affiancate a quelle popolari di Afanas'ev, tra cui campeggia nel titolo, guarda caso, quella di Maša e orso. Il nome di Bilibin dà ancora più lustro all'edizione, riassumendo in un solo volume più di un secolo di fiaba - popolare o letteraria che sia ${ }^{65}$.

Dall'altro le fiabe sono parte integrante del corpus poetico di Puškin, benché spesso relegate al ruolo di opere minori ${ }^{66}$, ma comunque da inquadrare all'interno dell'arte del poeta. A questa seconda categoria appartengono senza dubbio le prove di Tommaso Landolfi (introdotte da un saggio di Angelo Maria Ripellino) e Cesare G. De Michelis, due grandi studiosi della cultura e della letteratura russa. Qui l'interesse scientifico prevale su quello commerciale, l'intento precipuo è far conoscere una parte dell'opera di Puškin meno nota al pubblico dei lettori, non per forza russisti, senza alcun riferimento o orientamento verso il pubblico di bambini o ragazzi.

Rimane infine da esaminare l'esempio più rilevante in termini di presenza e significato sul mercato editoriale italiano: I quattro libri di lettura ${ }^{67}$ di Lev Tolstoj, pubblicati in Russia nel 1875, ma già quasi tutti presenti nell'Azbuka (1872) e nel Novaja azbuka (1875). Come per Puškin, se i capolavori di Tolstoj erano stati tradotti a breve distanza dalla loro uscita in patria, i Libri di lettura vedono la luce in italiano per la prima volta nel 1928 per la casa editrice Monanni ${ }^{68}$. Quella di Angelo Treves però è una

\footnotetext{
${ }^{64}$ A. Puskin, Fiabe e leggende, a cura di C. Poesio, ill. di B. Zago, appendice didattica di M. Cassuoli, Milano, Fabbri Editori, 1989, pp. 93-111.

${ }^{65}$ A. Puškin, A. Afanasev, Masha e orso e altre fiabe russe, ill. di I. Bilibin e N. Bosnia, Milano, BUR, 2015. Nel colophon si specifica quali fiabe appartengono a quale autore e si specifica l'illustratore di Maša e orso, Nella Bosnia. La fiaba L'ochetta bianca è attribuita a Puškin, ma se si tratta, come sembra, di Belaja utočka è in realtà una fiaba popolare di cui ne esiste una versione di Afanas'ev.

${ }^{66}$ Per fortuna ricollocate nel loro giusto spazio: "Come ha mostrato Vladimir Propp [le fiabe in versi] travalicano ampiamente il dato folklorico. Sotto spoglie di vivida e insistita 'russità' esse sono il portato d'un raffinato progetto letterario (sovente su base 'colta'), che le colloca a pieno diritto nel contesto della sua opera maggiore". A. Puškin, Fiabe in versi, op. cit., risvolto di copertina.

${ }^{67}$ Qui si prendono in considerazione le edizioni che comprendono uno o più libri di lettura. Singoli racconti sono usciti in parecchie edizioni per bambini e ragazzi, per esempio quella della casa editrice La Scuola del 1951 intitolata I migliori racconti per ragazzi, rinarrati da Nonno Pazienza in cui compaiono alcune storie tratte dai Libri insieme a racconti più tardi dello scrittore.

${ }^{68}$ Siamo a ridosso di quel momento di passaggio nella storia dell'editoria italiana e della ricezione della letteratura slava in cui negli editori subentra una attenzione criticamente più motivata e si assiste a una saldatura fra ragioni estetiche e programma editoriali. Grazie a riviste come "Novecento", "Solaria", "II Convegno", ma soprattutto di "Russia. Rivista di letteratura, storia, filosofia" e "Rivista di letterature slave" di Ettore Lo Gatto, con la fondazione a Torino della casa editrice Slavia e la nuova sensibilità di editori come Monanni, Ricciardi, Alpes, Stock, Sonzogno, Vallecchi e altri, oltre all'attività dell'Istituto per l'Europa
} 
traduzione dal francese, più precisamente dalla versione di Charles Salomon, al quale lo scrittore russo aveva regalato poco prima di morire una copia dei quattro libri di lettura. Dobbiamo aspettare il 1954 per avere una traduzione integrale dal russo, di Nicola Odanov, per la casa editrice Longanesi. Da quel momento in poi i libri di lettura vengono tradotti o ristampati di continuo, separatamente o in volume unico, fino all'edizione di ISBN del 2013.

Una tappa importante è rappresentata dall'operazione della casa editrice Fabbri che nel 1959 pubblica i quattro volumi nella traduzione di Luigi Ardenzi e a cura di Delfino Tinelli; l'orientamento è pedagogico, la scelta e traduzione dei racconti sono esplicitamente orientate alla percezione infantile. Einaudi (1964) e Mondadori (1998) sono invece le prime case editrici a offrire una versione filologicamente corretta dell'opera, pubblicando tutti i racconti dell'originale, senza omissioni o aggiunte, nell'ordine in cui erano stati pensati originariamente da Tolstoj.

I due approcci traduttivi che emergono in maniera distinta seguono in qualche modo il suggerimento del "doppio binario" segnalato per Puškin: da una parte un atteggiamento "filologico" rispetto al testo, dall'altro un indirizzo "pedagogico" della traduzione ${ }^{69}$. È chiaro che il pubblico di riferimento cambia di conseguenza - adulto nel primo caso, giovane o infantile nel secondo. La traduzione "pedagogica" offre più spunti di riflessione e presenta differenti gradi di intervento autoriale nei confronti dell'originale. Ardenzi, per esempio, tende ad aggiungere una morale o quantomeno una spiegazione della storia del tutto assente in russo:

Один человек пошел в лес, срубил дерево и стал распиливать. Он поднял конец дерева на пень, сел верхом и стал пилить. Потом он забил клин в распиленное место и стал пилить дальше. Распилил, вынул клин и переложил его еще дальше. Обезьяна сидела на дереве и смотрела. Когда человек лег спать, обезьяна села верхом на дерево и хотела то же делать; но когда она вынула клин, дерево сжалось и прищемило ей хвост. Она стала рваться и кричать. Человек проснулся, прибил обезьяну и привязал на верёвку70.

Il racconto è semplice e lineare, senza intervento diretto dell'autore. Nella versione italiana invece compare questa chiusa:

Orientale in pochi anni si assiste a un più radicato inserimento dello studio del mondo slavo in ambito italiano. Cfr. G. Tortorelli, L'Italia che scrive (1918-1938). L'editoria nell'esperienza di A.F. Formiggini, op. cit., pp. 84-104.

${ }^{69}$ I due termini sono tratti dall'articolo di E. Freda Piredda sulle traduzioni italiane dei Libri di lettura di Tolstoj. Cfr. E. Freda Piredda, Russkie knigi dlja čtenija: raznye napravlenija $v$ ital'janskich perevodach $i$ ich ispol'zovanie v prepodavanii RKI, Materialy IV meždunarodnogo seminara perevodčikov, izd. Muzej-usad'ba Jasnaja Poljana, Tula, 2010, pp. 23-30.

${ }^{70}$ L.N. Tolstoj, Sobranie sočinenij v 22 tomach, T. 10, Moskva, Chudožestvennaja literatura, 1982, pp. 18-19. 
Tutta colpa della coda!... La scimmia infatti può ben tentare di copiare l'uomo, ma non può riuscirvi. Perché la scimmia ha la coda, e l'uomo no... ${ }^{71}$.

Anche in Lev, volk i lisica (II leone, il lupo e la volpe) i finali della versione russa e italiana non coincidono:

Как растянул лев волка, лисица засмеялась и говорит: - Так-то, брат; господ не на зло, а на добро наводить надо ${ }^{72}$.

Ardenzi elimina le parole della volpe e ne aggiunge di proprie:

Dal che si vede che chi vuol fare il furbo corre i suoi rischi, specialmente se si imbatte in uno più furbo di lui ${ }^{73}$.

Gli interventi non riguardano soltanto la conclusione delle storie, ma anche la presentazione di alcuni episodi, decisamente ammorbidata se non proprio censurata nella variante in lingua italiana. Nel racconto Ljaguška i lev (La rana e il leone) il leone schiaccia con la zampa la piccola rana dopo che questa lo ha spaventato con il suo gracidare. II traduttore decide che la scena è troppo cruenta per un pubblico così giovane e così la sostituisce con un'osservazione personale, di pietas nei confronti del più debole: "Era un animale così piccolo e innocuo..." ${ }^{74}$.

La traduzione si adatta così alla sensibilità e agli obiettivi finali del testo, forse cercando di mantenere lo spirito e la funzione delle storie originali di Tolstoj, pensate per insegnare ai bambini di Jasnaja Poljana a leggere e ampliare il proprio bagaglio intellettuale. Nell'Italia degli anni Cinquanta, in pieno boom economico e alle prime avvisaglie di consumismo incontrollato, si sente l'esigenza - o almeno questo pare il messaggio - di un controllo e di una selezione dei contenuti da mostrare ai bambini in forme edulcorate e mai troppo dirette.

Ancora più in là negli intenti moralizzatori si spinge la casa editrice La Scuola nel 1951 con I migliori racconti per ragazzi, rinarrati da Nonno Pazienza (ripubblicati ancora nel 1984). In questo caso le storie di Tolstoj sembrano più ispirare o dare il pretesto per testi nuovi, completamente riscritti. Dietro la figura di Nonno Pazienza si cela il pedagogo Giovanni Bitelli (1875-1962) ${ }^{75}$ che avvisa genitori e bambini su come debba essere interpretata e letta l'opera di Tolstoj: “Quest'opera, con cui l'Editrice La Scuola mantiene

\footnotetext{
${ }^{71}$ L. Tolstoj, Il primo libro di lettura, Milano, Fabbri, 1973, p. 24.

${ }^{72}$ L.N. Tolstoj, Sobranie sočinenij v 22 tomach, op. cit., p. 178.

${ }^{73}$ L. Tolstoj, Il quarto libro di lettura, Milano, Fabbri, 1973, p. 17.

${ }^{74}$ L. Tolstoj, II primo libro di lettura, op. cit., p. 50.

75 “Bitelli, dopo la parentesi socialista e la conclusione del primo conflitto mondiale, aderì con convinzione al fascismo (sue nel '24 un'antologia per le scuole degli scritti di Mussolini e nel '37 la monografia paraviana Mussolini) anche se sostanzialmente nelle posizioni critiche relative alla letteratura per l'infanzia [...] è possibile rilevare una mescolanza di tolstoismo male assimilato, di vecchio nazionalismo, di spirito 'interventista rivoluzionario' alla Corridoni, di pruderie piccolo-borghese”. P. Boero, C. De Luca, La letteratura per l'infanzia, op. cit., p. 383 [nota 20].
} 
la tradizione di edizioni accurate ad un prezzo accessibile, si rivolge ai ragazzi. Tolstoi non è propriamente uno scrittore per ragazzi, ma non per questo i giovani non devono accostarlo. Naturalmente era necessaria una revisione, a volte decisa, del testo..." ${ }^{76}$.

Le revisioni sono in effetti molte, tanto da rendere difficile definire il volume una traduzione delle favole di Tolstoj; basti pensare che nel racconto Mužik i vodjanoj (in italiano diventa La scure d'oro) il protagonista non è lo spiritello padrone delle acque, bensì un angelo ${ }^{77}$.

Siamo qui agli estremi della diffusa tendenza, anzi maggioritaria fino agli anni Sessanta, e di cui Bitelli è il più significativo rappresentante, "a legare la produzione per l'infanzia alla scuola, a 'proteggere', insomma, la letteratura giovanile con una cappa di moralismo e didattismo" 78 .

Tolstoj è l'autore che meglio poteva essere manipolato a questi scopi, per il suo manifesto interesse pedagogico verso l'infanzia e le tante riflessioni circa l'etica, la morale, la disciplina. Profonda è la sua ricerca, linguistica prima di tutto, per entrare in contatto con i figli dei contadini della sua tenuta. Una tale operazione editoriale travisa invece al peggio lo spirito profondo degli insegnamenti dello scrittore di Jasnaja Poljana, riportando anche una idea distorta del suo pensiero a scapito di bambini e adulti.

A partire dagli anni Duemila aumenta il numero di favole o racconti singoli di Tolstoj, accompagnati da bellissime immagini che ribadiscono il ruolo centrale dell'illustrazione nel libro per l'infanzia. La casa editrice EL si cimenta con l'adattamento di Filipok, le Edizioni Paoline pubblicano La casa di Martin, Lapis presenta una scelta di favole tratte dai Libri di lettura e Fatatrac costruisce un libro di sole illustrazioni con il testo scritto nell'ultima pagina, diviso per "episodi", ispirato alla favola II vecchio del bosco e i due topolini.

\footnotetext{
76 L.N. Tolstoj, I più bei racconti per ragazzi, rinarrati da Nonno Pazienza, Brescia, La Scuola, 1984 [copertina].

77 Ibid., p. 38.

${ }^{78}$ P. Boero, C. De Luca, La letteratura per l'infanzia, op. cit., p. 383 [nota 20].
} 


\title{
Сказочная повесть в творчестве Владимира Кантора
}

\author{
(Паулина Вуйциковска-Вантух)
}

под редакцией Марии Ненароковой

Жил на свете таракан,

Таракан от детства... Федор Достоевский ${ }^{79}$

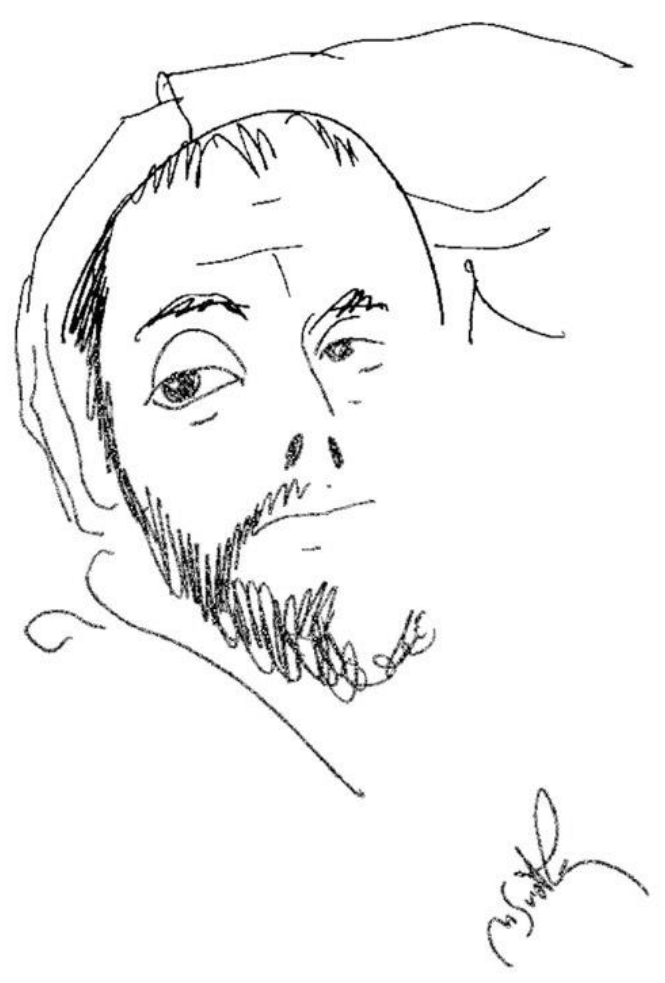

Рисунок 14 - Портрет Владимира Кантора, художник Максим Светланов
Романы-сказки ${ }^{80}$ Владимира Кантора (1943) Победитель крыс и Чур были напечатаны в 90-тые годы XX века, до того, как в 2006 году литературоведы Ольга Лебедушкина, Сергей Чупринин и Наталья Иванова провозгласили «сказочный бум» в современной русской литературе ${ }^{81}$. (Лебёдушкина 2007, Иванова 2006, Чупринин 2006). Первой в 1991 году в издательстве имени Сабашниковых вышла книга Победитель крыс, которая была посвящена сыну писателя - Мите ${ }^{82}$. За нее в 1992 году Кантор был номинирован на литературную премию Русский Букер. Сказка Чур, написанная для дочки Маши, была издана на семь лет позже

\footnotetext{
${ }^{79} Э$ пиграф к книге Чур.

${ }^{80}$ Я буду придерживаться именно такого жанрового определения, которое дает книгам сам автор. Тем не менее, по жанровым признакам тексты скорее всего принадлежат к жанру повести-сказки (одна сюжетная линия, ограниченное количество героев, небольшой объем, выразительный конфликт). Однако стоит отметить, что сказочные повести нередко получают жанровый подзаголовок "роман-сказка» (Три толстяка Ю. Олеши, Белка А. Кима, Кощей и Ягда или небесные яблоки М. Вишневецкой и др.). Как замечает Наум Лейдерман в работе Теория жанра, романизация жанра повести - это попытка расширить конфликт повести, „объективировать связи между главным конфликтом произведения и «целым миром»" (Н. Лейдерман 2010, 263).

${ }^{81}$ По мнению литературоведов, на переломе XX-XXI вв. наблюдается возрастающий интерес писателей и читателей к жанрам сказки как в русской, так и в мировой литературе. О том свидетельствует появление множества произведений прямо или косвенно относящихся к жанру сказки. Среди русских писателей, которые в это время обратились к сказке - Л. Петрушевская, А. Кабаков, Д. Быков, В. Пелевин, Т. Толстая, Л. Улицкая, А. Степанов, Б. Акунин и многие другие. Причины «сказочного бума» разные, Ольга Лебедушкина, Наталья Иванова и другие критики указывают прежде всего на кризис постмодернизма, востребованность литературы, утверждающей этические ориентиры, а также привлекательность жанра сказки.

${ }^{82}$ Книга была написана на десять лет раньше, в годы 1982-1983.
} 
в издательстве Московский Философский Фонд. Книги вышли тиражами 75000 и 1500. Они были положительно приняты критиками, как отмечает и сам автор. В интервью Елене Погорелой писатель так говорит о своем романе Победитель крыс: «Сказка эта пользовалась большой популярностью, да и сейчас гуляет по Интернету, ее кто-то оцифровал, перевел в удобный для электронных книг формат» (Погорелая, онлайн). Что примечательно, интерес ксказочным произведениям Кантора не падает, а растет - в 2017 году сказка Чур была переиздана в журнале «Волга», а в 2018 году в философском журнале «Гефтер».

Владимир Кантор является признанным в России писателем и философом, знатоком литературы Федора Достоевского и мысли Владимира Соловьева. Критики упоминают сказочные тексты Кантора, рассуждая об общей тематике его творчества. Напомним, что Владимир Кантор является также лауреатом престижных премий ${ }^{83}$ и автором выдающихся научных и философских работ ${ }^{84}$ : Русский европеец как явление культуры (2001), Между произволом и свободой. Квопросу о русской ментальности (2007), Любовь кдвойнику. Миф и реальность русской культуры (2013), а также многих литературных произведений: Два дома (1985), Крокодил (1990), Крепость (1996), Гид: Немного сказочная повесть (2007) Смерть пенсионера (2008) и другие. Последний художественный текст Владимира Кантора с длинным заглавием Нежить, или выживание на краю подземного мира. Странная повесть, фантазия в духе Борхеса был опубликован в журнале «Нева» в 2017 году. Как можно легко заметить, писатель продолжает работать в фантастическом жанре, в котором условность сюжетной ситуации позволяет затронуть универсальные, общечеловеческие темы.

В Западной Европе Кантор известен прежде всего как либеральный философ, его научные статьи были изданы во Франции, Германии и Италии. О польской рецепции сказок Владимира Кантора рассуждать еще рано. Пока на польский язык переведена только одна книга Кантора - Крокодил. Книга была издана в 2007 году в Академическом издательстве «Dialog» с иллюстрациями известного художника Бохдана Бутенко, автора комиксов и сотрудника многих детских журналов («Świerszczyk», «Płomyczek», «Miś»). Перевод с русского сделала Валентина

\footnotetext{
${ }^{83}$ Владимир Кантор (1945) стипендиат фонда Генриха Бёлля (1992). По версии известного французского журнала «Le Nouvel Observateur» (2005) входит в список двадцати пяти крупнейших мыслителей современного мира. Дважды получил премию «Золотая Вышка» (2009 и 2013) за достижения в науке. Его тексты переведены на английский, немецкий, французский, итальянский, чешский, польский, сербский, эстонский языки.

${ }^{84}$ Полная библиография творчества Владимира Кантора была составлена к 70-летию философа, профессора Высшей Школы Экономики и издана в 2015 году. Доступна онлайн: https://www.hse.ru/mirror/pubs/lib/data/access/ram/ticket/61/1541498346bad6140d1a7a3a13e3bbdd 738c92f590/Библиография\%20В.К.\%20Кантора1.pdf
} 
Миколайчик-Тжчинска. Книга остается известной в узком кругу читателей любителей русской литературы ипрофессиональных русистов. Польские исследователи посвятили несколько научных статей литературному творчеству Владимира Кантора (Krystyna Pietrzycka-Bohosiewicz, Halina Waszkielewicz 2006-2007, Urszula Trojanowska 2015, 2016). Возможно, что ситуация изменится в недалеком будущем, потому что, как удалось выяснить у самого писателя, сейчас идет работа над польским переводом сказки Чур. Следует еще упомянуть, что в 2006 году в журнале «Newsweek» было напечатано интервью с Владимиром Кантором, темой которого являлось европейское наследие России (Flip Memches 2006, онлайн).

Сказки Владимира Кантора Победитель крыс и Чур, в основу которых частично положен личный опыт, дополняют творческий портрет писателя ипо мнению исследователей являются неотделимой частью его творчества. Сюжеты романов-сказок Кантора изобилуют философскими вопросами, касающимися становления личности, смысла существования, свободы выбора. Тексты многослойны, насыщены множеством культурных символов и литературных цитат, в связи с чем при чтении требуют особого интеллектуальных усилий. Самое важное, что они продолжают проблематику, разрабатываемую писателем в романах, повестях и рассказах. В связи с вышесказанным нельзя рассматривать сказочные романы Владимира Кантора лишь в рамках детской или юношеской литературы. Они скорее всего принадлежат к ряду двухадресных произведений, как Хоббит Джона Толкина или Алиса в Стране чудес Льюиса Кэрролла.

Как замечает исследовательница Марина Загидуллина, каждая повесть или рассказ у Кантора превращаются в развернутое доказательство философской идеи, которая чаще всего «спрятана» в явной или реминисцентной культурной отсылке (Загидуллина 2004, онлайн). В случае романов Победитель крыс и Чур основным источником вдохновения для философских рассуждений писателя стали европейские и русские волшебные сказки, а также классические произведения русской литературы - Пушкина, Достоевского, Чуковского и многих других. 


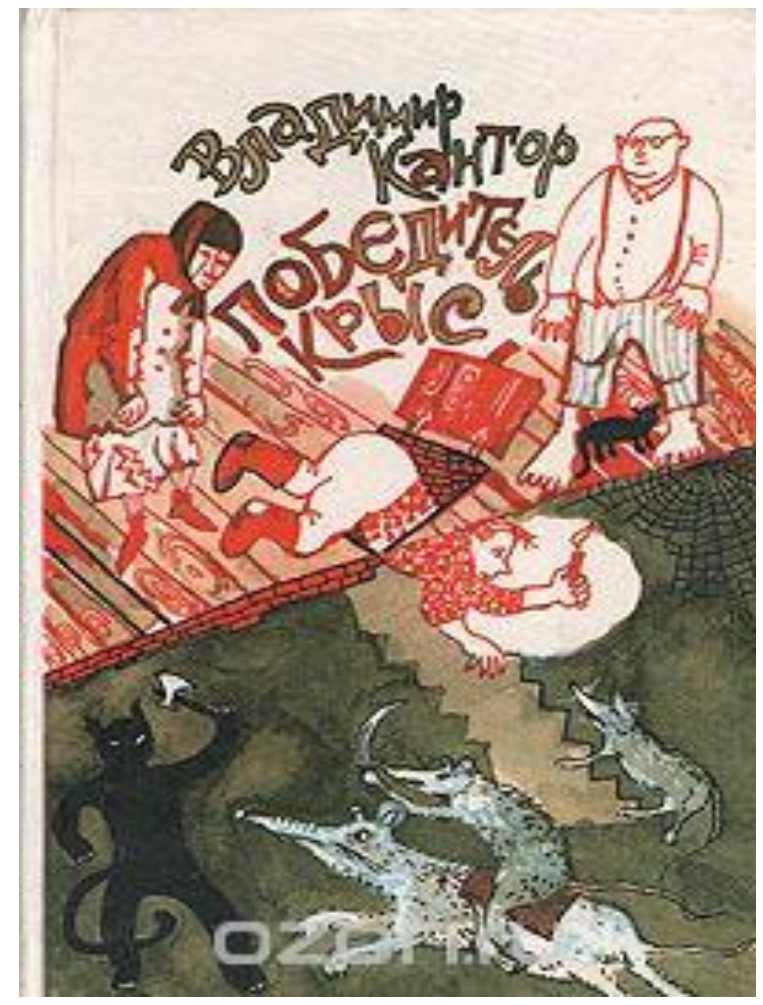

Рисунок 15 - Обложка сказки

"Победитель крыс", художник Максим Кантор

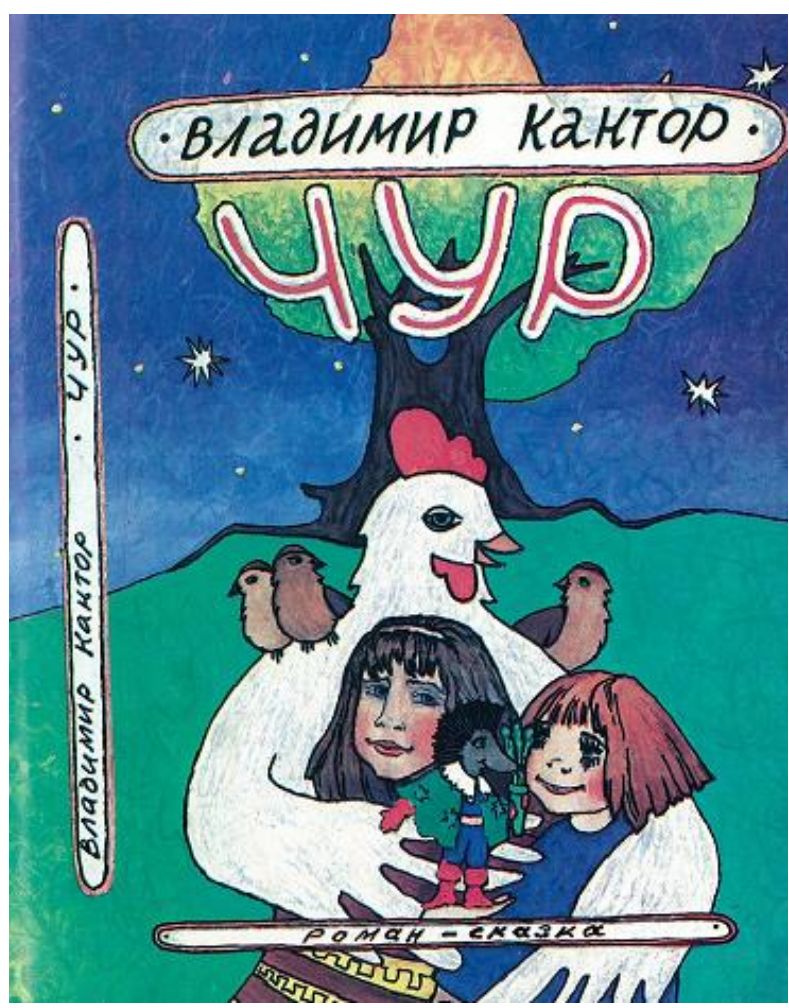

Рисунок 16 - Обложка сказки "Чур", художник Наталья Григорян

В анализированных мною сказочных произведениях также обнаруживается тип героя интеллигента - книжного мальчика ${ }^{85}$ (другие ипостаси этого героя философ, писатель, ученый), который является характерным для всего литературного творчества писателя (Trojanowska 2016, 18??) Тема взросления этого героя последовательно становится лейтмотивом творчества Кантора. Татьяна Мицук констатирует: «[...] в общем-то, он (Кантор - П. В.-В) пишет единый текст, и его герои переходят из повести в рассказ, из рассказа - в роман, из романа - в сказку и т. п.» (Мицук 2014, 240). Владимир Кантор сам родом из профессорской семьи, и поэтому так легко узнать в судьбе книжного мальчика, ставшего потом взрослым интеллигентом, автобиографические черты. Поиски авторской идеи и использование личного опыта вего самых разных произведениях вполне обоснованы, что подтверждают приведенные ниже слова Кантора:

Главное, что я вынес из своей семьи, - кредо, которое там сформировалось, что стремиться к успеху и славе неприлично, что главное - это быть верным себе, пытаться точно передать, что чувствуешь и думаешь. Это главное, а не признание современников. Повторю, я никогда не писал с ориентацией на какой-либо слой, на некоего читателя. Я писал только для

\footnotetext{
${ }^{85}$ В случае романа-сказки Чур следует говорить о „книжной девочке”.
} 
себя, понимая, что если я точен в своих словах, дошел до некоего дна, то там, как говорил Лев Толстой, находится нечто, что присуще всем думающим людям. И они рады это общее найти (Погорелая 2014, онлайн).

Стоит заметить, что идейное кредо Владимира Кантора реализуют полностью персонажи именно его детских произведений, которые достигают успеха в поисках истины ив борьбе с несправедливостью. Другие литературные персонажи из

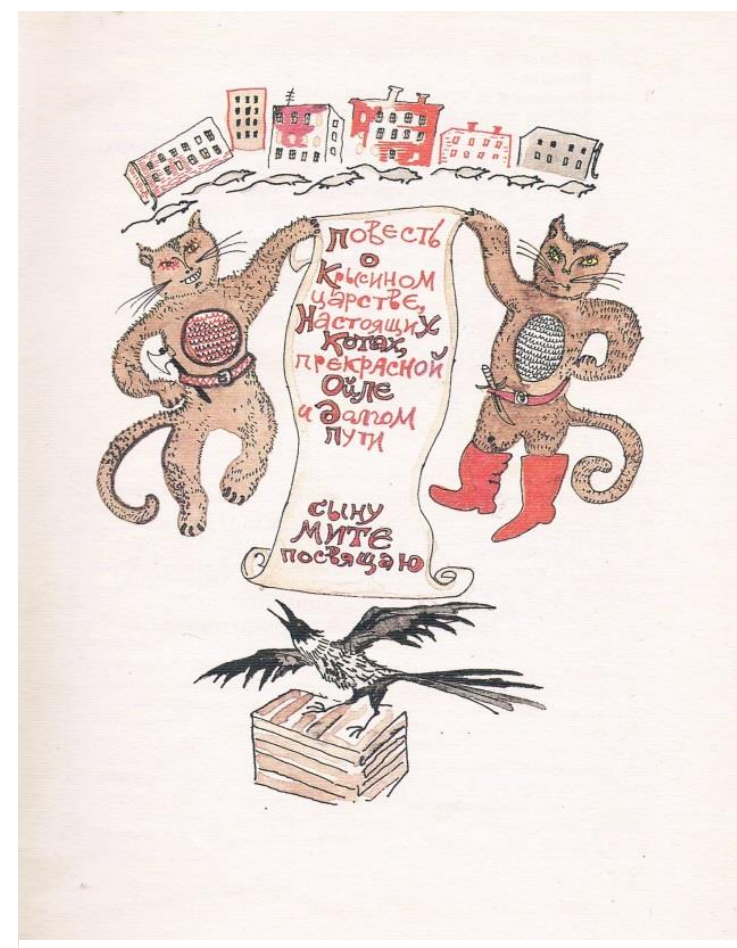

Рисунок 17 - Рисунок - Рисунок из книги ,Победитель крыс" Владимира Кантора, художник Максим Кантор, Издательство имени Сабашниковых (1991), c. 3. взрослых книг Кантора или стремятся кидеалу, или являются его противоположностью, как например, «деградированный герой» - Леопольд Помадов из романа Крокодил (Waszkielewicz 2015, 107-119).

Отвечая на вопрос, зачем тогда автор обратился к жанру сказки, если идея, заложенная в романах Победитель крыс и Чур, не является новой, стоит указать на три вещи. Вопервых, выбор жанра мотивирован возрастом адресата книги (героям книг соответственно 9 лет и 15 лет) и желанием писателя заинтересовать собственных детей, удовлетворить их читательские запросы. В результате романы-сказки Кантора стали чем-то вроде отцовского наставления для сына и дочери. Во-вторых, есть основания предполагать, что мифологическая проблематика, заложенная в волшебной сказке, кажется автору до сих пор актуальной. В-третьих, автору несомненно понадобился фантастический элемент, который позволяет представить экзистенциальные проблемы в отдаленной перспективе и стимулирует воображение читателя. Выбор цитаты из сказки Павла Катенина (1792-1853) Княжна Милуша, открывающей книгу Победитель крыс, подтверждает эти предположения: «Я сам не раз, гоним судьбой враждебной, Бичом ее пробитый до костей, Спасался в край поэзии волшебной [...]» (Кантор 1991, 4). В интервью, процитированном ранее, Владимир Кантор поясняет, что фантастический элемент вообще характерен для его писательской манеры - он 
присутствовал в романе Крокодил, повестях Два дома, Смерть пенсионера и, конечно, в сказках, о которых говорит так: «А сказка - это тема детства, но там именно в фантасмагорическом, сказочном плане рассказывается о нашей жизни, где взрослеет мальчик. Но ведь эта фантасмагория и есть на самом деле реальность» (Погорелая, онлайн). Важную роль при выборе жанра сыграл воспитательный элемент волшебной сказки, связанный с положительной развязкой действия, преодолением страха и беды. Благодаря финальной победе героя, реализуется компенсационная функция и целительное действие сказки, на которое указывал в своих трудах Бруно Беттельгейм (Bettelheim 1976).

На первой странице романа-сказки Победитель крыс можно прочитать, что это «повесть о крысином царстве, настоящих котах, прекрасной Ойле и долгом пути». Сюжет основан на известной народной немецкой легенде о Гамельнском крысолове и одновременно развивается вокруг вступительного фрагмента к поэме Александра Пушкина Руслан и Людмила «У лукоморья дуб зеленый; Златая цепь на дубе том: И днем и ночью кот ученый, Все ходит по цепи кругом [...]» (Пушкин 1960, 9). Такое смешение западноевропейских и исконно русских культурных образов не должно удивлять, ведь Владимир Кантор - создатель и поклонник идеи «русского европейца». Поэму Пушкина читает герою бабушка, сидящая у его кровати, когда пятнадцатилетний Борис заболевает. Поссорившись с отцом из-за пустяков, взволнованный и расстроенный юноша уезжает к бабушке. От злости он думает: «Пусть я умру, а папа ничего не сумеет сделать [...] А если не умру, то все равно я ему покажу, что я без него смогу совершить нечто великое» (Кантор 1991, 8). Получается, что герой предсказывает наступающую болезнь и последующие события. Слова поэмы Пушкина завораживают подростка. Из-за высокой температуры ипод впечатлением бабушкиного чтения он начинает бредить. Борис оказывается в фантастическом мире, где крысы захватили власть над человеком. С этого момента реальное (бабушка, читающая Пушкина идедушка, убивающий крыс в подвале деревенского дома, болезнь Бориса, ссора с родителями) и нереальное (крысиная туманная страна, крысы-оборотни на конях, хата Бабы Яги, коты в человеческом облике, поезд-дракон, способный проглотить пассажиров итд.) будет постоянно смешиваться в его сознании. С самого начала, когда Борис попадает в другой мир, он бегает по бесконечному лабиринту лестниц и площадей, пытаясь убежать от крыс, что придает тексту характер фантасмагории, узнаваемой ив мрачном рассказе Александра Грина Крысолов. От случайно встреченного им кота-оборотня юноша узнает, что он спаситель человечества («Борис-борись!» «Царь Борис-победитель крыс!») и после долгих рассуждений решает принять на себя миссию по спасению мира. Борис отправляется в долгий путь. Ему необходимо добраться до Лукоморья, 
чтобы пробудить рыцарей, спящих у высохшего дуба, так как только они в состоянии победить крыс. Путешествие Бориса можно проследить на карте, помещенной на обложке книги, которой нарисовал художник Максим Кантор - брат писателя.

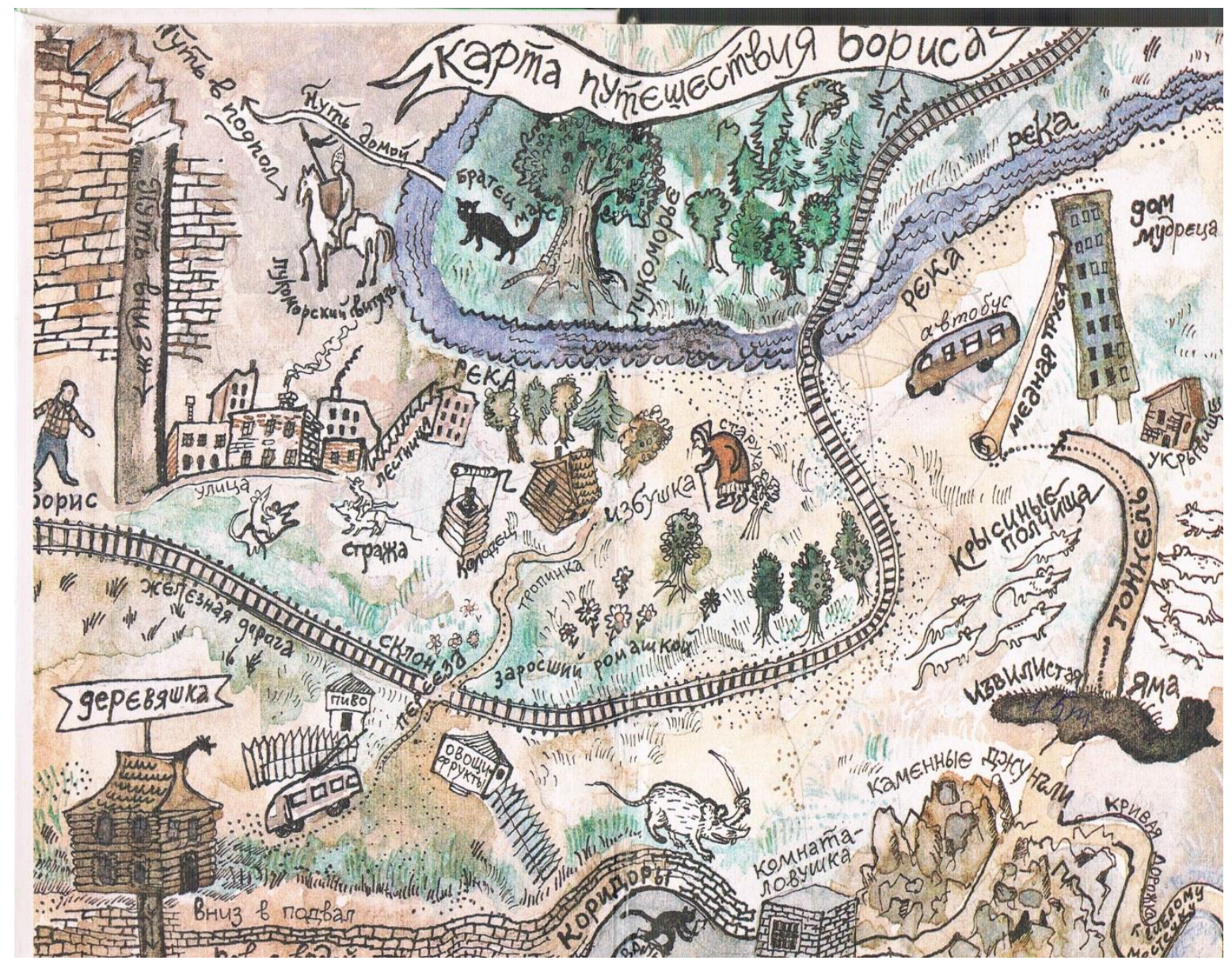

Рисунок 18 - Форзац сказки ,Победитель крыс" Владимира Кантора, художник Максим Кантор, Издательство имени Сабашниковых (1991).

На пути к Лукоморью герой вынужден преодолевать препятствия, сражаться с врагом, скрываться и убегать от опасности, но самое главное заключается в том, что нужно самостоятельно принимать правильные решения. Достичь успеха помогают Борису коты-оборотни, внучка Бабы Яги - Эмили/Ойле, и наконец Мудрец, встреча с которым окончательно убеждает Бориса в правильности его усилий. В последней сцене романа-сказки появляются все элементы, описанные Пушкиным, - идуб зеленый, и кот, ходящий по цепи, и леший, и витязи, и царевна. Сказочным Русланом является сам герой, он пробуждает витязей, которые отправляются на бой с крысами. Борис доводит до конца свою миссию ипросыпается на сундуке у бабушки совсем другим человеком как в физическом, так и в духовном смысле: 
Борис кивнул. Ему не хотелось говорить. Все это был сон. А теперь начиналась жизнь. В голове у него была ясность, в теле - легкость [...] Потому что перед ним была теперь своя собственная жизнь, которой он не боялся отныне и в которой - он был уверен в этом - ему еще встретятся и настоящая Дружба и настоящая Любовь. И теперь ему казалось, что он готов к этим встречам (ibidem, 266).

Сюжет сказки Чур развивается очень похоже, но опирается на культовую сказку Корнея Чуковского Тараканище, цитата из которой появляются в эпиграфе «Вот и стал Таракан победителей, И лесов и полей повелителем». Героиня сказки девочка Маша, дочь книгочеев - как определяет ее повествователь, вместе со своими подружками, чудесно ожившими куклами, спасает принца Ёжика Карла от

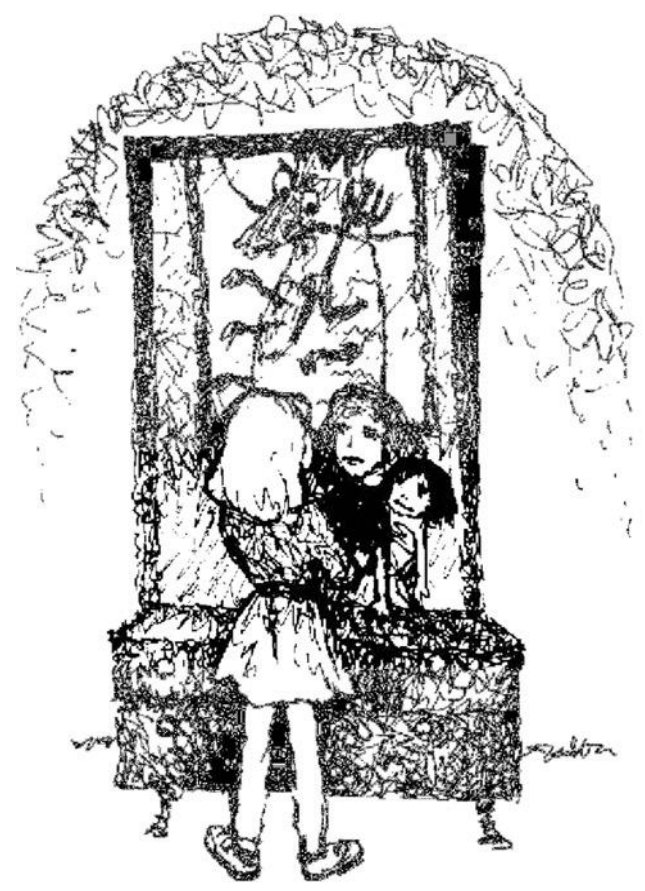
злого Тыковкина, колдуна Карачуна и тараканов. Помогает ей добрый волшебник Эрнест Яковлевич Чур. Это сосед девочки, друг семьи, умный и обладающий магической силой защитник, участие которого в событиях определяется словами стихотворения К Чуру поэта Льва Мея (1822-1862):

«Но, Чур, от моего не отходи порога И береги покой моей родной семьи! Ты твердо знаешь, кто чужие и свои, Остерегай же нас от недруга лихого, От друга ложного и ябедника злого, От переносчика усердного вестей, От вора тайного и незваных гостей [...] ${ }^{86}$ (Кантор 1999, 7).

Рисунок 19 - Рисунок из книги

„, Чур" Владимира Кантора, художник Наталья Григорян,

Издательство МФФ (1998), с. 3.

${ }^{86}$ Первоначально стихотворение было посвящено собаке поэта. 
Интересно, что слово чур, по мнению, исследователей восходит кимени славянского ${ }^{87}$ бога родового очага, оберегающего границы земельных владений (Бронгауз, Ефрон 1890-1907, т. 39). Такую же информацию автор помещает в тексте сказки (ibidem, 6). Героиня часто пользуется междометием «чур» именно в функции заклятия: «Только, чур, друг дружке помогать» (34), «я уже сказала: чур, я буду смелая и, чур, Тыковкину помогать не буду»(81); «Чур меня. Чур за меня. Чур со мной» (22). Примечательно, и сегодня это слово является частью детского фольклора. Восклицание "Чур меня» означает «не трогай, я в стороне», так как раньше он оберегал от нечистой силы (Мокиенко, Никитина 2007, 743).

Стоит обратить внимание на еще одну деталь. В случае истории о Маше автор использует иной прием введения фантастического элемента, отличный от сказочного сна. Маша попадает в другой мир через зеркало (Кантор 1999, 9), символика которого широка, ав сказках оно встречается очень часто (Сказка о Елене Премудрой, Белоснежка, Сказка о голом короле, Сказка о мертвой царевне и семи богатырях А. Пушкина, Королевство кривых зеркал В. Губарева). Домой Маша возвращается по чудесной реке, которая вливается прямо в окно ее комнаты. Девочка плывет по ней одна, оставляя в другом мире принца, волшебника Чура и оживших подружек-кукол. Волшебное приключение заканчивается вмомент возвращения Маши в детскую комнату.

Сказки Кантора в основном отличаются друг от друга в идейном плане (а и то не полностью, а в деталях), что связано прежде всего с возрастом адресата произведений. Как известно, читатель ребенок ичитатель-юноша это разные читатели, у каждого из них свои проблемы. Например, у школьницы, девятилетней девочки Маши пробуждается смелость и самостоятельность. Благодаря приключениям в волшебной стране она выходит из детского, уютного пространства своей семьи и комнаты, полной игрушек, - наружу, вмир, где кроме доброжелательных людей есть и плохие, а кроме настоящих друзьей - фальшивые. Взросление Маши повествователь прокомментирует словами: «Вэти дни она научилась молчать, когда надо. И почти ничего не бояться» (ibidem, 156). Главная идея романа - сказки Чур высказывается героиней на одной из первых страниц текста.

А я могу (рассказать - П. В.-В. ) про то, как надо делать, чтобы не ссориться и всем быть добрыми. Ведь на свете живет Злость, она нападает на людей илюди становятся злыми. И тогда дети расшвыривают свои игрушки, а взрослые всё грязнят и между собой ругаются и дерутся. Как же справиться с нею? я считаю, что по злости Злость победить нельзя. Надо ее по доброте победить (ibidem, 7).

\footnotetext{
${ }^{87} Э$ то не единственный славянский мотив в сказке Чур. В ходе сюжета упоминаются и полудница женский демон славянской мифологии, а также дуб, как объект славянского сакрального культа.
} 
Слова Маши соответствуют тому, как ребенок воспринимает окружающий мир - в речи девочки персонифицируется зло (злость нападает), его присутствие легко заметить ребенку в поведении людей (ссора, драка, беспорядок), кроме того, с некоторой наивностью обрисовываются цели и возможности героини. В ходе сюжета сказки оказывается, что Тыковкина итараканов можно победить чистотой и порядком, а волшебник Чур заключительное сражение над колдуном Карачуном ${ }^{88}$ выигрывает с помощью пылесоса! Путь Маши также можно проследить на карте, на которой центральное место занимает заколдованный дуб с дуплом. Для славян дуб является священным деревом. Тот же символ был использован автором в сказке Победитель крыс.

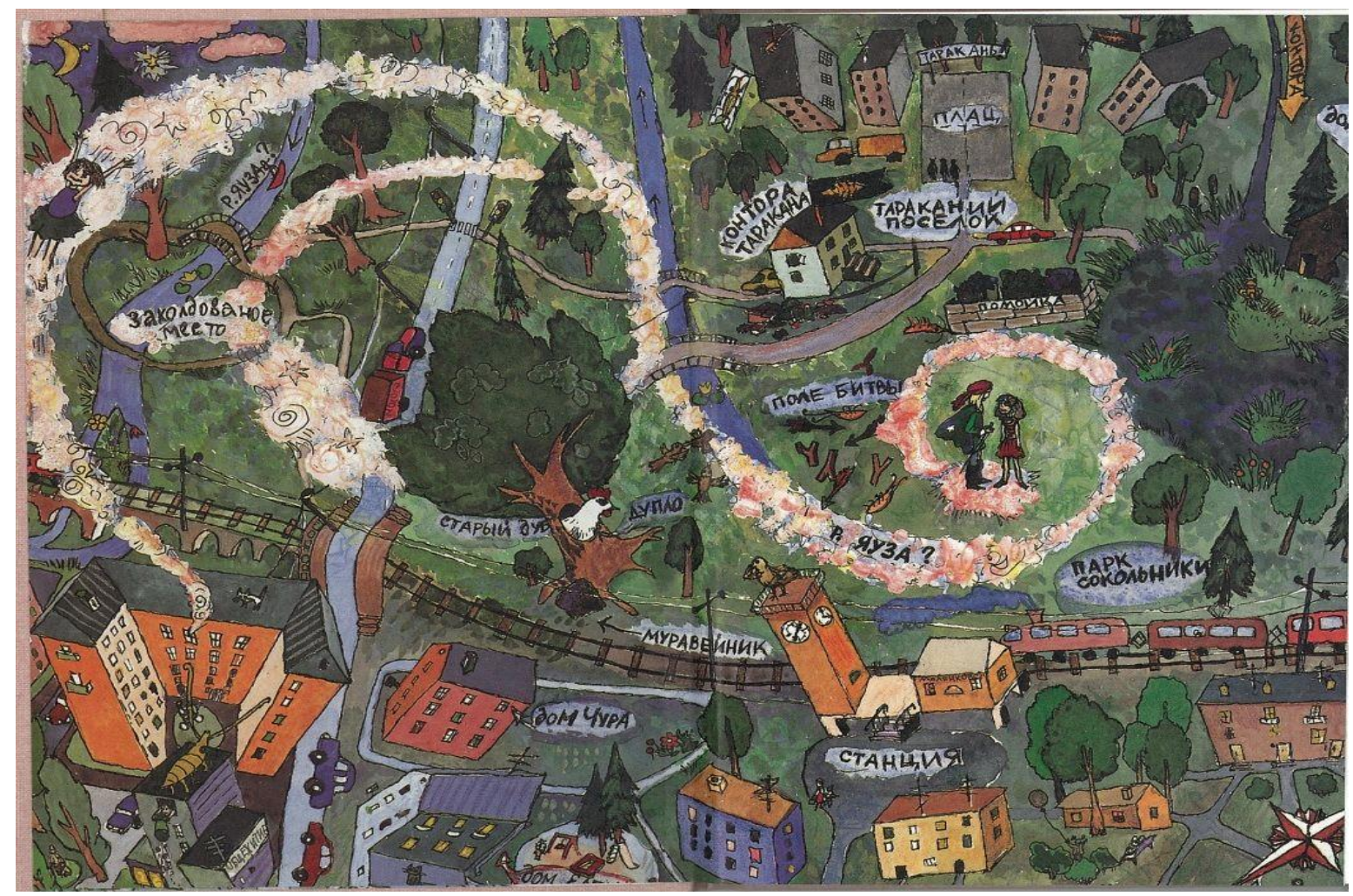

Рисунок 20 - Форзаи сказки , Чур" Владимира Кантора, художник Наталья Григорян, Издательство МФФ (1998).

Не так уж идалеко отошли они от захламленной полянки, как Маша неожиданно увидела и узнала знакомый дуб, который весной они с папой лечили: отдирали гниль, высохшую кору и обмазывали больные места глиной. Папа тогда сказал, что это не простой дуб, а сказочный, быть может, даже дерево жизни, которое соединяет влюбленных, дает приют усталым и гонимым, помогает добрым и храбрым.

\footnotetext{
${ }^{88}$ Добрый волшебник Чур иплохой колдун Карачун - оппозиционная пара в семантиколингвистическом плане. Карачун - древнеславянский бог нижнего мира, повелитель мороза, холода и мрака (Токарев 1957, 109).
} 
Стоит отметить, что в обозначенном на карте Тараканьем поселке на главном месте помойка, и везде разбросан мусор. Часть города, в которой живет Маша, тоже находится под угрозой: Главный Таракан сидит на высотном здании и ждет. Это неслучайно, что антагонистами героев своих сказок Владимир Кантор сделал крыс и тараканов, которые ассоциируются с грязью, дном общества иподпольной жизнью. Как утверждает в своей статье Марина Загидуллина, идея чистоты является лейтмотивом творчества писателя «Внешняя неопрятность, по Кантору, - знак замутнения духовных основ» (Загидуллина 2004, онлайн). И когда Маша говорит о том, что если на человека нападает зло, вокруг него становится грязно, следовательно, порядок становится символом духовной чистоты. Стоит заметить, что в идейном плане сказки Владимира Кантора схожи с христианским учением (непротивление злу насилием, добро должно победить, чистота духа выражается и во внешней красоте ичистоте) ${ }^{89}$. Эти принципы отражают гуманизм, веру в человека как носителя высших ценностей. Тамара Мицук замечает, что в прозе Кантора работают законы, которые зачастую не работают в реальности - законы совести и справедливости (Мицук 2013, онлайн). Понятия Добро и Зло (а также Любовь и Дружба) пишутся в книгах Чур и Победитель крыс с прописной буквы. Такой прием склоняет читателя к философским и этическим рассуждениям, так же как и многократное указывание на категорию человеческой души («На душе у неё тишина и покой», «Ведь у тараканов души нет, сердца тоже, а бесчисленны они, как песок в пустыне», «Что такое душа? Не понимаю. Это все поэты выдумали»). Особое, символическое значение автор придает понятию книга (книга как источник знаний, путь к пониманию мира, книга как сила мысли, книга как атрибут интеллигента). Она находится в центре сюжета обоих романов - о книгах беседуют Борис с Мудрецом, книгу читает бабушка больному Борису, книгу пишет отец Маши (кстати он тоже Борис!) и именно эту отцовскую книгу спасает от врагов девочка.

Очень интересной темой для рассуждений в контексте сказок Кантора является онтология Зла. Как положено в традиционных волшебных сказках, Зло у Кантора тоже выразительное, могущественное, признаки зла выражены ярко и определенно, чтобы не было сомнений, кому противостоят герои сказки. Однако у Кантора значения наслаиваются друг на друга и все получается более сложным, чем в традиционной сказке. Кроме уже названных признаков Зла, есть еще многие другие: тараканы икрысы персонифицируют зло коллективное, тоталитарное, уничтожающее индивидуальность в человеке, его оригинальность и независимость. Зло приносит с собой порабощение человека инесвободу, оно побеждает

\footnotetext{
${ }^{89}$ На это обращает внимание и Андрей Синявсикй в книге Очерк русской народной веры.
} 
насилием, захватывает умы (с помощью пропагандистских лозунгов - «Из грязи в князи», «Тараканье знамя - знамя побед», «Вся власть Таракану»), имеет глупых и преданных помощников, (например специалист по крысоведению Алек из романа Победитель крыс или кукла предательница в романе Чур) контролирует общество и притворяется чем-то другим (фальшивые коты в Деревяшке). Эта характеристика прямо ассоцируется с тоталитарной советской властью, которая изображена в виде крыс и тараканов, и вызывает у читателя особое отвращение (Trojanowska 2016, 184). Эффект тотальности зла усиливают детали: в крысиной стране все носят одинаковые имена - Александр, в тараканьей все читают одну газету - «Тараканий порядок»). Связь с исторической реальностью обнаруживает и Марина Загидуллина, когда пишет про роман Победитель крыс: «Ився эта сказка - никакая не сказка, а документ начала 80-х» (Загидуллина, онлайн). Хочется отметить, что в Крысином Императоре иГлавном Таракане легко рассмотреть черты Сталина - лидера Советского государства. В этом плане сюжет романов-сказок Кантора является метафорической картиной советского общества имеханизмов в этом обществе работающих. Существенно, что герои Борис и Маша вынуждены сначала осознать присутствие и опасность зла, без этого борьба вообще невозможна.

Вернемся к текстам книг. Если сказка Чур написана о победе зла добротой и грязи чистотой, то главной темой романа сказки Победитель крыс является проблема взросления молодого человека и все что связано с вхождением юноши во взрослую жизнь - первая любовь, плохие отношения с родителями (проблема отиов идетей), попытка остаться собой среди других (дилемма пить или не пить в компании друзьей, оригинальность одиночки), тема ответственности за свои решения ипоступки (выбор между принципом удовольствия ипринципом реальности). Это во многом психологический роман об инициации, изображающий в метафоричной форме внутренний мир юноши - книжного мальчика, который, как замечает Марина Загидуллина «хочет уйти от книжного мира в мир настоящий, мир парней, которые не читают книг, но ведут себя, как заправские "романные бандиты”, лихо сплевывают сквозь зубы, называют девчонок "чувами" и пускаются в отчаянные драки» (Загидуллина 2004, онлайн). Побеждая крыс, Борис побеждает свой страх, слабость и неуверенность в себе, при этом обретает самостоятельность. Из этого следует, что интерпретация всего происходящего в духе психоанализа вполне оправдана. Хочется отметить, что одним из первых пациентов Сигизмунда Фрейда был человек-крыса (Rattenmann).

В другом мире, крысином царстве, Борис встречает Мудреца - наставника, во многом напоминающего собственного отца героя произведения. Во время философской беседы с Мудрецом подросток узнает, что главное в жизни - это иметь 
свою цель и быть верным своему выбору. «Во всяком случае запомни, что твоя жизнь и твое_здоровье зависят от_твоего душевного состояния, от того, имеешь ли ты право уважать себя, служил ли ты Добру или Злу, или постыдно бежал с этого поля битвы?» (Кантор 1991, 200). Получается, что быть взрослым означает быть самостоятельным, это подчеркивается Мудрецом многократным повторением местоимения «ТЫ». Хочется заметить, что активная деятельность и целеустремленность отличают как Бориса, так и Машу от Леопольда Помадова, героя уже упоминавшейся повести Владимира Кантора Крокодил. Польская исследовательница Халина Вашкелевич характеризует этого героя, как проигравшего в жизни интеллигента, не способного к действию на благо общества, не владеющего самим собой: „Niemożność czynu, a raczej niezdolność do bycia panem samego siebie, tłumaczy także brak dokonań na polu służenia społeczeństwu, w walce o prawdę i wolność" (Waszkielewicz 2015, 114). Как можно предполагать, Борис и Маша являются примерами подлинного героя, способного жертвовать собой ради высшей цели и брать на себя ответственность. Они созданы как противоположность пассивному иэгоистичному герою. Водной из заключительных сцен сказки Победитель крыс Борис пьет таинственной напиток, полученный от рыцарей, благодаря которому, еще лучше осознает, в чем суть его миссии.

«Странен был вкус этого напитка: горький он был и соленый одновременно будто вся горечь мира, все слезы впитались в его. Сделав первый глоток, понял вдруг Борис, что не сможет отныне жить спокойно, если знает, что есть где-то униженные и оскорбленные люди, что отныне он ответствен за них за всех, за их беды и несчастья и что он приложит все усилия, чтобы прогнать крыс и освободить людей» (ibidem, 259).

Здесь хочется подчеркнуть педагогический смысл романов-сказок Кантора. Они имеют ярко выраженную на разных уровнях текста (сюжет, высказывания героев имеющее характер прямых поучений, выделенные, самостоятельные фрагменты текста - например Притча о Зеленой стране 90 ) универсальную мораль. Это не свойственно новейшей литературе, стремящейся в основном к идейному релятивизму и свободе читательской интерпретации, но необходимо в рамках детской и юношеской литературы которая прежде всего направлена на передачу нравственных ценностей. Арзамасцева и Николаева пишут: «Дети жаждут счастливой развязки, требуют правдивости даже в фантастически-сказочных произведениях, они очень чутки кэтической позиции автора иждут от него одобрения мира детства [...] Отрицательные герои изображаются как враги детства и носители

\footnotetext{
${ }^{90}$ Притчу рассказывет Борису кот-оборотень Степа во время беседы харчевне Деревяшка. Это аллегорический рассказ о настоящей оригинальности, которая очень редка. Быть оригинальным по-настоящему это не значит выделяться внешним признаком, как Голубой человек одиночка в Зелёной стране. Оригинальность внутри человека и не всегда обнаруживается сразу (164).
} 
отрицаемых детьми этических черт» (Арзамасцева, Николаева 2005, 21).

Помимо нравоучительности о принадлежности сказок Кантора кдетской и юношеской прозе свидетельствует наличие познавательной информации из разных областей науки. Факты из истории, культуры, религии, литературы и даже биологии перемешиваются с литературными цитатами, пословицами, поговорками («с ежом даже медведь в берлоге не уживётся», «бей своих, чтобы чужие боялись», «тот здоровья не знает, кто болен не бывал»), которые знакомят молодого читателя с языком культуры, вводят в традицию, просто обучают. Это соответствует словам Арзамасцевой: «Язык детской книги должен быть особенно богат и выразителен, чтобы помочь ребенку расширить горизонты, научить новым формам речи» (Арзамасцева, Николаева 2005, 29). В сказке Чур, которая предназначена детям младшего возраста много уменьшительно-ласкательных слов и детской атрибутики (подружки, сестренка, Ирочка, девочки, плюшевый Ёжик, игрушки, зверюшки, солнышко, детская комната). Автор приводит цитаты из волшебных сказок и книг, ныне принадлежащих кдетскому кругу чтения (Золушка, Али-баба и сорок разбойников, Тараканище К. Чуковского). Видим также большое количество неологизмов (отараканить, стараканить, втараканить, Тараканск и т. п.) и поговорки, в которых меняется автором обычно одно слово словом «таракан» и благодаря тому, выражения приобретают новое - комическое значение («подлость на тараканьих ножках», «клясться Тараканом», «один Таракан ведает!»).

К традициям сказки (памяти жанра) Кантор относится так же, как многие современные писатели. Творчески работая с текстами культуры использует жанровые условности для передачи авторской оригинальной идеи. Сказки Победитель крыс и Чур почти полностью соответствуют правилам жанра волшебной сказки, как по формальным, так и по идейным признакам. Если попытаться сделать морфологический анализ этих сказок по Проппу, окажется, что в них можно найти почти все функции, начиная с вредительства, заканчивая на победе положительного героя над антагонистом, и то по очереди (Пропп 1998, 23-51). Типы героев вполне соответствуют жанру - кроме главного героя и антагониста, есть и помощники (волшебник Чур, кукла Ирочка,), персонаж, отправляющий героя в путь (Мудрец), и царевна/царевич (Эмили, Принц Ежик Карл, ibidem, 59-61). Структурная модель обеих сказок такова:

- Исходная ситуация - герой оказывается в другом мире, в котором ему приходится бороться за справедливость;

- Другой мир захвачен антагонистом. Герой выступает против коллективного врага - нации крыс и тараканов.

- Герой отправляется в путь и преодолевает препятствия. 
- Герой подвергается испытаниям.

- Герою помогают магические помощники.

- Герой одерживает победу.

Присутствуют в сказках Кантора и остальные элементы, указанные в определениях жанра волшебной сказки: магия (звери-оборотни, говорящие куклы, мотив превращения героини в лягушку, поезд - дракон), дихотомический образ мира, в идейном плане - победа добра над злом. Сохранены также функции волшебной сказки: компенсационная, воспитательная и развлекательная (Paulina WójcikowskaWantuch 2018, 51-57).

Это не значит, что произведения Владимира Кантора полностью традиционны. Поскольку это авторские сказки, вних сильно отражается индивидуальный стиль писателя и его личное мировоззрение, а время создания сказок - конец 80-х годов XX века (триумф русского постмодернизма) оказало большое влияние на поэтику произведений. Сказки Владимира Кантора безусловно современны, и в них отражаются перемены, каким подвергался жанр сказки в конце XX века. Так, их отличает интертекстуальность. Автор указывает в примечаниях к книгам сказкам фамилии писателей, тексты которых он использовал. Среди них стихотворения А. Пушкина, Г. Державина, В. Жуковского, А. Буниной, Н. Карамзина, И. Тургенева, О. Мандельштама, К. Чуковского, Б. Окуджавы, В. Высоцкого, Э. Логвинской, самого автора, а в сказке чур - стихи, сказки, поговорки и придуманные слова дочери писателя. Текст произведений Кантора просто-таки соткан из других литературных текстов, в идейном плане он находится в постоянном философском диалоге с литераторами разных эпох и времен. Особенно четко заметны переклички и аллюзии к произведениям Федора Достоевского, можно даже указать некие семантические группы слов-ключей, которые функционируют у обоих писателей (подполье, таракан, подросток, христианство, миссия и многие другие). Наблюдается у Кантора множество автоцитат - как я уже указывала, повторяются образы героев, мотивы, идеи, характерные для творчества писателя. Если учесть вышеуказанное, получается, что литературность является главной чертой романовсказок Кантора. Литературные цитаты сопровождаются богатой культурной символикой (таракан, крыса, книга, дерево) и архетипикой (отец, мудрец, дорога). С насыщенностью текста цитатами связана синкретичность. Текст сказок неоднородный, в него вплетены песни, стихотворения и пословицы, хотя согласно правилам традиционного жанра соблюдается линейность событий. Что касается языка сказок, он современный, лишен стилизации под фольклор, традиционных формул, присказок итак далее. Зато приведенные при анализе примеры доказывают, что автор реализует игровой подход к языку. 
Подведем итоги. Романы-сказки Владимира Кантора это высококачественная литература, многослойная и универсальная, соединяющая в себе многие черты традиционной и современной литературной сказки. Книги Чур и Победитель крыс выходят за пределы детской и молодежной литературы, благодаря насыщенности культурными аллюзиями, становятся литературой для всех. Серьезность идейного содержания романов-сказок Кантора перемешивается с игровым подходом к языку и литературному материалу, что делает эти книги очень привлекательными для самых разных читателей. 


\section{Заключение}

\section{(Ева Кудрявцева Маленова)}

Научная новизна данной работы заключается в соединении разных точек зрения на сказку. Монография организована хронологически - от сказки народной до сказки авторской в ее современном облике, при этом основной призмой является Россия. В хронологическом плане в монографии представляются модификации жанра сказки на материале русских сказок (от фольклорных до литературных), и вопросы его восприятия на избранной территории средней Европы.

Русской исследовательнице, Марии Ненароковой, удалось в ее двух главах показать сначала проблемы перевода и восприятия русской народной сказки на английском языке, и затем традицию восприятия и издания западноевропейских (чешских, польских, итальянских и английских) сказок в России. Анализы М. Ненароковой доказали, что западноевропейские сказки прочно вошли в сказочную культуру России, также, как и русские сказки в культуру за рубежом. Более того, можно констатировать, что позиция зарубежных сказок в России разделила судьбу домашних сказок (запреты и гонения на сказку в 20-30-е гг.; интерес к фольклору разных народов, пробудившийся в 40-е гг.) Основываясь на первой главе, мы приходим к заключению, что некоторые сказки становятся (по различным причинам) своеобразным стереотипическим символом целой сказочной культуры конкретного народа (что показано на примере сказки „Златовласка“ в русском контексте). Подобный вывод можно сделать на основе чешского контекста по отношению крусским сказкам - таким же концентрированным символом русского фольклора и сказочной культуры является чешский перевод сборника И. Карнауховой «Красота ненаглядная» и фильм-сказка «Морозко».

В области литературной сказки мы обратили внимание, во-первых, на текст о Буратино А. Толстого и на его итальянский прототип К. Коллоди, и шире - на роль обоих текстов в современном польском ичешском культурных контекстах. Мы показали историю переводов выбранных произведений на оба языка, провели сравнительные анализы переводов, ина основе вышеуказанного мы приходим к выводу, что восприятие иностранной сказки в другой культуре (какой бы она ни была нейтральной в идеологическом плане) зависит отнюдь не только от качества перевода. В Чехии и Польше в наше время русские сказки практически не издаются. В наше время сюжет А. Толстого является востребованным лишь в России, тогда как в Чехии и Польше издатели предпочитают итальянский первоисточник К. Коллоди. Во всех трех странах (Россия, Польша, Чехия) замечена тенденция упрощать и сокращать сказочные тексты, т. е. приспосабливать их для читателей поменьше. 
О взаимосвязи и различиях Пиноккио и Буратино было уже много написано (Акимова, А. С.; Курий, С.; Новиков, В. И.; Минералова, И. Г. и др.), поэтому следующая, итальянская глава направлена не на связь Коллоди - Толстой, а на историю итальянских переводов русских литературных сказок. Глава о русской литературной сказке в Италии не только контрастирует, но иподтверждает вышеуказанное. В итоге выявлен факт, намеченный уже впольском ичешском контекстах - русская литературная сказка в итальянских переводах представлена отнюдь не полностью, предпочтение издатели однозначно отдают классике произведениям А. С. Пушкина и Л. Н. Толстого.

Ссылаясь на главу об индивидуальном стиле В. Кантора, мы повторяем, что сказка является актуальным и очень продуктивным жанром, впитавшим в себя черты многих других жанров, отражающим важные тенденции современной литературы. На материале сказок В. Кантора подтвержден факт, что сказка адресована в наше время не только детям, но и взрослым, и таким расширением читательского круга жанр возвращается ксвоим корням и изначальному предназначению. Помимо того, судьба сказок В. Кантора за рубежом, вернее отсутствие их переводов (в контексте Польши, Чехии и Италии), может послужить свидетельством о неинформированности о русской литературной сказке. Данный фактор можно считать ключевым в контексте восприятия любого произведения в иноязычной среде. 


\section{Summary}

The chapter A RUSSIAN FAIRY TALE IN ENGLISH: THE DIFFICULTIES OF ITS TRANSLATION AND CULTURAL ADAPTATION (MN) focuses on the difficulties encountered while translating Russian folk tales into English. The object is the English translations of Russian folk tales, made from 1873 to 2000 . The subject of the paper is conveying characteristic features of Russian fairy tales in English translations. The study material is the existing translations of Russian folk tales, carried out both by English and Russian native speakers. The main objective of the research is to see how the ways to overcome difficulties while translating Russian fairy tales changed gradually. The tasks of the study were as follows: to identify and describe the main difficulties faced by translators of Russian folk tales; to determine a number of invariable elements that occur in all texts, and to comment on the variants of their translation; to identify and describe the range of transformations used in the translation, to analyze the role of the translator's commentary while translating Russian fairy tales; to note the translation losses and their causes. The study shows that the Russian folk tale is written down in several versions, so when analyzing translations, it is necessary to focus on invariable elements of the texts. These are the titles of fairy tales, the names of characters, words with diminutive suffixes, the realia, formulaic expressions, invariable adjectives, paired synonyms, archaisms. While translating the usual losses are the inability to convey the rhythm and rhyme of the original, replacing the pair of synonyms with one word, shifts of meaning. The most frequent transformations are translation by analogy, transliteration, entire reformulation of the text. Transcription and Ioan translation are used less commonly. The translators of Russian fairy tales tend either to preserve their characteristic features or to use simpler grammar and neutral vocabulary. By the end of the XXth century the second tendency has prevailed.

The next chapter focuses on the history of translation, publication and presence of the West European folk tale in Russia. The object of study is the publication of Czech, Polish, Italian fairy tales in Russian translations from the middle of the 19th century to the present day. The subject of the study is the tradition of the publication and the perception of the West European fairy tale in Russia. The study material is the editions of Czech, Polish, Italian, English fairy tales in the collections of the Russian State Library (RSL, Moscow) and the Russian National Library (NLR, St. Petersburg). The main objective of the research is to trace how the tradition of translation, publication and perception of Czech, Polish, Italian, English fairy tales developed in Russia. The tasks of the study were as follows: to find all the editions of fairy tales in the RSL and the NLR; collect information on publishing houses that specialized in publishing fairy tales, and on their publishing policy; to analyze the forewords to the publications; to summarize information on publishing and 
translation strategies, existing in Russia; to trace the origin of traditions in the publication of fairy tales, to point out the interpreters of fairy tales, to assess the perception of the West European fairy tale in Russia and its place in the culture of the country. The study showed that foreign tales, Czech, Polish, Italian, English ones, were adopted into the culture of Russia through translations, and they shared the fate of the Russian fairy tales: the bans of the 20-30s and the popularity since the 40s. Some tales, f.eg. the Italian and English ones, were read by generations of Soviet and Russian children; others, like the Polish tales, are not so well known. Sometimes a fairy tale, f.eg. "Goldilocks", written down by Karel Erben, becomes a symbol of the nation's folklore. Nevertheless, in Russia every fairy tale finds its reader, teaching him or her to be good, merciful, just.

The chapter The Italian Original and the Russian Translation - Pinocchio and Buratino in the Polish context (PW) is devoted to the problem of the Polish reception of a juvenile novel "Pinocchio" by Carlo Collodi and "The Golden Key, or the Adventures of Buratino" by Aleksey Tolstoy. The author begins by sketching the publication and translation history of Carlo Collodi's book, which even today enjoys popularity in Poland. The novel about Pinocchio belongs to the juvenile canon in Poland and is required reading in schools. The Pinocchio character is still recognizable in the Polish culture, although we can observe the lowering of the age of the potential reader. This stands in contrast to the reception of the Russian version of the adventures of the wooden puppet. Aleksey Tolstoy's fairy tale, "The Golden Key, or the Adventures of Buratino" has been translated only once, by Julian Tuwim. In spite of the fact that in the Polish People's Republic Aleksey Tolstoy's book has been republished several times, it did not manage to take root in the readers' minds, and contemporarily it is not remembered. In the chapter the author analyses as well an excellent translation of "The Golden Key, or the Adventures of Buratino" into Polish, penned by Julian Tuwim, and provides an outline of the reception of both texts in the Polish theatre, cinema and popular culture.

The chapter titled Italian Original and Russian Translation - Pinocchio and Buratino in the Czech context deals with Czech reception and translation. The chapter contains a presentation of the history of translations by C. Collodi and A. Tolstoy into Czech. Comparison of current issues in Russian and Czech proves the different situation in both countries. As in the previous chapter, the analysis of the Czech translation is limited to the names of the main literary characters. The end of the chapter is devoted to the contemporary Czech reception of Russian children's literature, based on the author's monograph.

The chapter of Julia de Florio aims at investigating the fortune of Russian literary fairy tales in Italy. Despite the considerable amount of translations that have been published throughout the century the major Russian authors are still quite unknown to 
the Italian public and are not part of the canonic texts of children's literature in Italian language.

Chukovsky's, Marshak's and Mikhalkov's poems received some attention in the 70s and 80 s thanks to the close political relations between Italy and the USSR. Majakovsky's too was already known as a great author of lyric and civic poetry and his fame probably contributed to the appearance of his children's verses in Italian.

Pushkin and Tolstoy, of whom there has been a long tradition of studies and translations in Italy since the 19th century, are a separate subject. Their fairy tales and short stories are periodically reprinted or new editions published thanks to their status as classical authors, both for adult and young people. Together with the history of reception some reflections about the translation of children's literature, poetry in particular, are put under discussion.

The chapter A Fairy-tale Novel in the Oeuvre of Vladimir Kantor (PW) concerns this part of the work of Vladimir Kantor, a contemporary writer and philosopher, which is not as familiar to the audience as his novels and academic books. The subject of the analysis are the writings meant for the young reader, the fairy-tale novels "Победитель крыс" (1991) and "Чур" (1998). Both of these texts were created for the writers' children and they contain autobiographical elements. The author of the chapter focuses on the themes and plots of these works, underlining their close links to the tradition of the European and Russian fairy tales. The contemporary novel-fairytales of Kantor can be formally inscribed into the tradition of a literary fairy tale, and apart from the conventional elements, they contain the postmodern features, e.g. intertextuality, syncretism, self-reflexivity, and the use of parody and stylistic devices. On the ideal plane, the novel-fairytales of Kantor reflect the moral creed of the writer, the essential feature of which is the conviction of the necessity of choosing the good side, making the right and brave life choices as well as fighting with one's weaknesses. The key role in the novel-fairytales of Vladimir Kantor is played by the images of purity/beauty and dirtiness/ugliness, which are allegorical representations of good and evil. 


\section{Список рисунков и графиков}

Рисунок 1 - Обложка издания "Złoty kluczyk czyli niezwykłe przygody Buratino» Алексея Толстого в польском переводе Ю. Тувима, Zysk i S-ka (2014).

Рисунок 2 - «Пиноккио» в переводе Зофии Яхимецкой с иллюстрациями Марцина Шанцера, Nasza Księgarnia (1954).

Рисунок 3 - Иллюстрации Марцина Шанцера к книге «Пиноккио» в переводе Зофии Яхимецкой, Nasza Księgarnia (1954). Источник иллюстрации:

https://jarmila09.wordpress.com/2011/11/14/pinokio/ [дата обращения 20.12.2018].

Рисунок 4 - Обложка книги «Pinokio. Historia pajacyka» в переводе Я. Миколаевского с иллюстрациями Р. Инноченти, Media Rodzina (2011).

Рисунок 5 - Обложка диска с польской аудиозаписью сказки Пиноккио. Текст зофия Яхимецка по мотивам сказки Карло Коллоди, музыка Рушард Селицки, MUZA (1976).

Рисунок 6-Обложка книги «Złoty kluczyk czyli niezwykłe przygody Buratino» Алексея Толстого в переводе Ю. Тувима, Czytelnik (1949).

Рисунок 7-Иллюстрации Бронислава Малаховского к книге Алексея Толстого "Золотой ключик или Приключения Буратино», (1936). Источник:

https://golos.io/ru--istoriya/@ramin/istoriya-illyustracii-bronislav-malakhovskii-zolotoiklyuchik-ili-priklyucheniya-buratino [дата обращения 20.12.2018].

Рисунок 8-Обложка книги «Złoty kluczyk czyli niezwykłe przygody Buratino» Алексея Толстого в переводе Ю. Тувима, Czytelnik (1953).

Рисунок 9 - Обложка издания: «Złoty kluczyk czyli niezwykłe przygody Buratino» Алексея Толстого в переводе Ю. Тувима в художественном оформлении Малгожаты Коморовской, издательство Votum (1992).

Рисунок 10 - Обложка издания: TOLSTOJ, Aleksej Nikolajevič. Zlatý klíček aneb Buratinova dobrodružství. 2. vyd., 1. vyd. ve SNDK. Praha: SNDK, 1950.

Рисунок 11 - Обложка издания: TOLSTOJ, Aleksej Nikolajevič. Zlatý klíček aneb Buratinova dobrodružství. 4. vyd., (v Lid. nakl. 1. vyd.). Praha: Lidové nakladatelství, 1970. 120, [5] s.

Рисунок 12 - Обложка издания: TOLSTOJ, Aleksej Nikolajevič. Zlatý klíček aneb Buratinova dobrodružství. 5. vyd. Praha: Albatros, 1979.

Рисунок 13 - Обложка издания: MALETIĆ, Gordana a Aleksej Nikolajevič TOLSTOJ. Zlatý klíček. 1. vyd. Ilustroval Ana GRIGORJEV. Praha: Fortuna Libri, c2013. Fortuna Junior. ISBN 978-80-7321-704-4.

Рисунок 14 - Портрет Владимира Кантора, художник Максим Светланов. Источник иллюстрации: http://gefter.ru/archive/25024 [дата обращения 20.12.2018].

Рисунок 15 - Обложка сказки „Победитель крыс" Владимира Кантора, художник Максим Кантор, Издательство имени Сабашниковых (1991). 
Рисунок 16 - Обложка сказки „Чур" Владимира Кантора, художник Наталья Григорян, Издательство МФФ (1998).

Рисунок 17- Рисунок из книги „Победитель крыс" Владимира Кантора, художник Максим Кантор, Издательство имени Сабашниковых (1991), с. 3.

Рисунок 18 - Форзац сказки „Победитель крыс" Владимира Кантора, художник Максим Кантор, Издательство имени Сабашниковых (1991).

Рисунок 19 - Рисунок из книги "Чур" Владимира Кантора, художник Наталья Григорян, Издательство МФФ (1998), с. 3.

Рисунок 20 - Форзац сказки „Чур" Владимира Кантора, художник Наталья Григорян, Издательство МФФ (1998). 


\section{Список использованной литературы}

\section{Источники на русском языке:}

«Почитайка», альманах. №2, 1994.

«Почитайка», альманах. №3, 1994.

Английские народные сказки. 1993. - 1690 с. Пер. с англ. Н.Шерешевской ISBN 5-265-02719-X

Английские народные сказки. М., ОАО Московские учебники, 2009.-109, [2] с. ISBN 978-5-7853-1083-4

Английские народные сказки. 1992. - 160 с. Пер. с англ. Н.Шерешевской ISBN 5-86-246-002-02

Английские народные сказки. Государственное издательство Художественной литературы.М, 1960 - 216 с.

Английские народные сказки. Москва, Государственное Издательство Художественной литературы, 1957. - 208 с. ISBN не указан.

Английские народные сказки. Составление, адаптация текста и комментарий В.А.Верхогляд. Упражнения, словарь Л.Т.Добровольской. Москва, Айрис Пресс, 2018. - 157, [2] с. ISBN 978-5-8112-5748-5

Английские сказки, собранные и обработанные Е.М.Чистяковой-Вэр. СПб, Издание В.И.Губинского, 1908. - 364 с.

Английские сказки. Издание журнала «Золотое детство». СПб, 1913. - с.160.

АРЗАМАСЦЕВА, И., НИКОЛАЕВА, С. (2005): Детская литература: Учебное пособие для студентов пед. ВУЗов. Москва: Академия, 2005, 576 с.

АФАНАСЬЕВ А.Н. 1984 (онлайн): Народные русские сказки А. Н. Афанасьева: В 3 т. М.: Наука, 1984-1985. - (Лит. памятники). Т. 1. - 1984. - С. 331-343

http://hobbitaniya.ru/afanasyev/afanasyev105.php [Дата обращения 03.05.2018]

БЕВЗ, Л., сост. (2007): Итальянский язык с Итало Кальвино "Волшебное кольцо". Москва: АСТ: Восток-Запад, 2007 - 316 с.

БЛОХ М.Я. И ДР. 2005: Блох.М.Я., Новикова Н.С., Олейник Н.Г. Учим русский через сказку: Тексты с параллельным переводом. Комментарии. Лингвистический анализ. Упражнения. М.: Флинта:Наука, 2005. - 96 с. ISBN 5-89349-554-3

БУЛАТОВ, М. (1955): Писатель и национальная сказка// Об изданиях сказок для детей. Москва, Государственное Издательство Детской Литературы Министерства Просвещения РСФСР, 1955. - 424 с сс. 46-68. ISBN не указан.

ВАВЖИНьЧАК, А. (2011): Русская литература в современной Польше [в:] ХХІ век. Итоги литературного десятилетия: язык- культура - общество. Материалы международной научно-практической конференции, 21 апреля - декабрь 2010 года, ред. Большакова А.Ю. и Дырдина А.А. Ульяновск: УлГТУ 2011, с. 317-322. 
Волшебные сказки Британии. сост., адаптация текста, коммент. В. А. Верхогляд, упражнения, слов. И. П. Твердохлебовой. Москва : Айрис-пресс, 2013 - 181, [2] c. ISBN 978-5-8112-5093-6

ГАВАЛЕВИЧ М. и СТАХЕВИЧ П. (1911): Польские народные Легенды о Богородице. пер.с польского В.Ходасевича. М., издание В.М.Саблина, 1911. - 134 с.

Гороховый Стручок - Огородный Старичок. Польские народные сказки. М-Л, Детгиз, 1953. -80 с.

ГОРЬКИЙ, М. (1989): О детской литературе, детском и юношеском чтении: избранное. М., Детская литература, 1989. - 224 с.

ЗАГИДУллИНА, М. (2004): Аутсайдер современного литературного процесса (художественный мир Владимира Кантора). Вестник Челябинского государственного университета 2004, 106-124 с.

ЗАГИДУЛЛИНА, М. (2004, онлайн): Морок иявь. О прозе Владимира Кантора. Москва: «Октябрь» 2004, №11 [онлайн]. Режим доступа: http://magazines.russ.ru/october/2004/11/zag11.html [дата обращения 4.05.2018]

Златовласка. Чешские народные сказки. Серия «Книга за книгой». Детгиз, 1954. $32 \mathrm{c}$.

Золотая книга сказок всех стран и народов. Перевод М.Благовещенской, А.Плещеевой, и Н.Рождественской. вступительная статья проф.А.Погодина. СПб.-М., издание товарищества М.О. Вольф, 1913. - 364 с.

ИВАНОВА, И. И. (1990): Чешские и словацкие народные сказки, перевод с чешс.и словацкого / [сост. и примеч. И. Ивановой ; ил. А. Белюкина] Москва: Худож. лит., 1990

ИВАНОВА, Н. (2006): Ultra-fiction, или Фантастические возможности русской словесности. „Знамя” 2006, $\mathrm{nr} 11.2$ Режим доступа: http://magazines.russ.ru/znamia/2006/11/iv1.html [дата обращения 4.05.2018]

Источник на краю света. Британские сказки. Издательство "Детская литература» M, 1969. - 272 c.

Источник на краю света. Британские сказки. СПб-М., издательство Речь, 2017. 256 c. ISBN 978-5-9268-2

Итальянские сказки, обработанные Итало Кальвино. Государственное издательство Художественной литературы. М., 1959. - 208 с. ISBN не указан.

Итальянские сказки. пер. Марии Андреевой под редакцией Максима Горького. Издание т-ва скоропечатни А.А.Левенсон. М, 1912. т.1-140 с. т.2. - 96 с.

КАНТОР, В. (1991): Победитель крыс, Москва: Издательство имени Сабашниковых 1991,272 c.

КАНТОР, В. (1999): Чур, Москва: Московский философский фонд 1998, 172 с.

КАРАБАНОВА, 3. (1914): Польские сказки. изд. т-ва И.Д.Сытина. М, 1914 - 292 с.

Карлик с длинными ступнями. М, издание книгопродавца А. Д. Сазонова, 1899 г., $32 \mathrm{c}$. 
КАРСКАЯ, Т.С. (1969): Божена Немцова и современные ей русские литератоы. Из истории чешско-русских литературных контактов второй половины ХІХ века. Автореферат диссертации на соискание ученой степени кандидата филологических наук. Ленинград, 1969. - 18 с.

Книга - друг ребенка. Воспитатели о детских книгах. Москва, Просвещение, 1964. - 207 с. ISBN не указан.

КУДРЯВЦЕВА МАЛЕНОВА, Е. (2017): Литературная сказка в индивидуальном стиле Геннадия Цыферова в контексте чешской рецепции русской литературы для детей и молодежи во второй половине 20 века. Брно: Masarykova univerzita, 2017. 182 c. ISBN 978-80-210-8521-3.

КУДРЯВЦЕВА МАЛЕНОВА, Е. (2018): «Бархатная революция» в истории чешских переводов русской детской литературы. In Ivo Pospíšil, Miloš Zelenka, Lenka Paučová. Česká slavistika 2018. Brno: Jan Sojnek - Galium, 2018, c. 83-94. ISBN 978-8088296-00-3.

КУРИЙ, Сергей (онлайн). Является ли «Золотой Ключик» плагиатом «Пиноккио»?. Школа жизни. [онлайн]. Режим доступа:

https://shkolazhizni.ru/archive/0/n-30350/ [дата обращения: 2019-05-02].

ЛЕБЕДУШКИНА, О. (2007, онлайн): Шехерезада еще жива, пока... „Дружба народов” 2007, № 3. Режим доступа: http://magazines.russ.ru/druzhba/2007/3/le12.html [дата обращения 4.05.2018]

ЛЕЙДЕРМАН, Н. (2010): Теория жанра. Исследования и разборы. Екатеринбург: «Словесник» 2010, 904 с.

ЛИПОВЕЦКИЙ, М. (2003 онлайн): Утопия свободной марионетки, или Как сделан архетип. (Перечитывая “Золотой ключик» А.Н. Толстого). „НЛО” 2003, № 63. Режим доступа: http://magazines.russ.ru/nlo/2003/60/lipov-pr.html [дата обращения 12.12.2018].

МАКСИМОВИч К.А. 1992: Максимович К.А. Птица Феникс в древнерусской литературе (К проблеме интерпретации образа) // Герменевтика древнерусской литературы. XI-XIV вв. Т. 5. М., 1992. С. 316-334. ISBN не указан.

МАРШАК, С.Я. (1964): Воспитание словом. Статьи. Заметки. Воспоминания. М., Советский писатель, 1964. - 584 с. ISBN не указан.

МЕДВЕДЕВА, Н.Б. (1951): Организационная и издательская деятельность А.М.Горького в области детской литературы// А.М.Горький и детская литература. М., Государственное издательство культурно-просветительской литературы, 1951. 36 с. сc.10- 21. ISBN не указан.

МЕДВЕДЕВА, Н.Б. (1989): А.М.Горький о детской литературе, детском и юношеском чтении// Горький М. О детской литературе, детском и юношеском чтении: избранное. М., Детская литература, 1989. - 224 с. сс.6-20.

МИФЫ НАРОДОВ МИРА 2008 - Мифы народов мира. Энциклопедия. т.2. М., Дрофа, 2008. - 720 с. ISBN 987-5-358-04213-1 (т.1).

МИЦУК, Т. И. (2013): Три книги Владимира Кантора. „Вестник Европы” 2012, 237-242 c. 
МОКИЕНКО, В., НИКИТИНА, Т. (2007): Большой словарь русских поговорок. Москва: ОЛМА Медиа Групп 2007, 784 с.

НЕМЦОВА, Б. (1863): О двенадцати месяцах. (с чешского). Извлечено из Северной пчелы. Спб. 29 марта 1863. В типографии Н.Греча. - 10 с.

НЕНАРОКОВА, М. (2018): Основы лингвостилистического анализа текста. Учебное пособие. Москва: Российский университет дружбы народов 2018, с. 186.

HЕЧAEB, А. (1955): О народных сказках в детской литературе// Об изданиях сказок для детей. Москва, Государственное Издательство Детской Литературы Министерства Просвещения РСФСР, 1955. - 424 с. сс.7-45. ISBN не указан.

ОВЧИНнИкОВА, Л. В. (2003) Русская литературная сказка ХХ века. История, классификация, поэтика. Москва, 2003. 381с.

Огонь, вода и честь. Богатое приданое. пер.с итал. Ю.Ильиной, обработка Н.Гессе. «Вокруг света», №11, 1958.

ПЕРЫШКО ФИНИСТА 2000 - Перышко Финиста. Русские сказки (на английском языке). М., Радуга, 2000. ISBN 5-7842-0107-7.

ПЕТРОВСКИЙ, М. (1986) Книги нашего детства. Москва, 1986.

ПЕТРОВСКИЙ, М. (2008): Книги нашего детства. СПб.: Изд-во Ивана Лимбаха 2006, $424 \mathrm{c}$.

ПЛОТНИКОВА Л. И., ЮЙШИНА Е. А. 2016: Русская ментальность в сказках:

этнопсихолингвистический аспект. Чита : Забайкальский гос. ун-т, 2016 - 207 с. ISBN 978-5-9293-1625-8.

ПОГОРЕЛАЯ, Е. (2013, онлайн): Где взрослеет мальчик. Владимир Кантор о двоящихся семьях, ручном пауке Бабы-яги и неприличности. «Независимая газета» [онлайн]. Режим доступа: http://www.ng.ru/person/2013-04-04/2_kantor.html [дата обращения 4.05.2018].

Подарок северного ветра. Итальянские народные сказки. Составление, задания, комментарии, словарь, И.Г Константиновой. СПб, Каро, 2015. - 112 с. ISBN 978-59925-1087-4

ПОЛЕВОЙ П.Н. 1874: Народные русские сказки в изложении П. Полевого . СПб.: тип. и хромолит. А. Траншеля, 1874. [14], 320 с.: ил.

Польские народные сказки. Л., Художественная литература, Ленинградское отделение, 1980. - 328 с. ISBN не указан.

Польские народные сказки. М.-Л., Художественная литература, 1965. - 384 с. ISBN не указан.

Польские сказки, изложенные по К.В.Войницкому и К. Балинскому. Спб, издание О.А.Гримма, 1880-92 с.

Польские сказки. К.Балинского, К.Войцицкого, А.Глинского, А.Дыгасинского, И.Крашевского, В. Пржиборовского, З.Моравской и др. СПб, издание В.И.Губинского, 1897. - 312, i-ii c. 
Польские сказки. Серия «Иллюстрированная сказочная библиотека Ф. Павленкова» №97. СПб, 1899 Типлграфия товарищества «Общественная польза». - 48 с.

ПРОПП, В. (1998): Морфология/Исторические корни волшебной сказки. Москва: Лабиринт 1998, 512 с.

Путешествие в сказку. Английские народные сказки. пер. Н.Шерешевской. М, Кристина и Ольга, 1993. - 96 с. Литературно-художественное издание. Для младшего школьного возрраста. ISBN 5-7086-0035-7

ПУШКИН, А. (1960): Собрание сочинений в десяти томах. Том третий. Поэмы и сказки. Руслан и Людмила. Москва: Государственное издательство художественной литературы 1960, 539 с.

РЫЦЕЛЬСКА, Б. (2018): О количественной иконичности в сказке Алексея Толстого Золотой ключик или приключения Буратино и ее польском переводе. Łódź: „Acta Universitatis Lodziensis. Folia linguisitca" 1993, № 27, c. 77-85.

СИняВСКИЙ, А. (2001): Очерк русской народной веры. Москва: Аграф 2001, 464 с.

Сказания древней Чехии. «Легенды, предания и сказки народов Европы». Пер. с чеш. Ф. Боголюбовой, М. Таловой. Сост. А. Платов . М. : Менеджер, 2000. - 351 с.

Сказки Золотой Праги. Саратов : Кн. изд-во, 1962. - 120 с.

Сказки. Русские народные сказки. Казахские народные сказки. Итальянские народные сказки. М, «Союзинформкино»,1991. - 208 с. ISBN не указан.

Сквозь волшебное кольцо Британские легенды и сказки. Пер. с англ. Н. В. Шерешевской. Москва: Правда, 1987.

СКВОРЦОВ, Ир. (1957): Сказки в деле воспитания первого детства // Вестник воспитания. Научно-популярный журнал для родителей и воспитателей. 1898, № 2. cc.190-196.

Скворцы и дрозды. пер.с итал. Э.Казаковой, обработка Н. Гессе. «Нева», №9, 1957.

Славянские сказки. Болгарские, чешские, польские и югославские. Для сред. возраста. - Ленинград : Лениздат, 1956. - 223 с.

Там, где Висла-река. Польские сказки. Для мл. возраста. Пересказ Н. Подольской. Москва : Детская литература, 1975. - 190 с.

TOKAРEВ, С. (1957): Религиозные верования восточнославянских народов XIX начала XX в. Москва-Ленинград: Издательство Академии наук СССР 1957, 163 с.

ТОлстоЙ, А. (2016): Золотой ключик, или Приключения Буратино: Издательство АCT; М.; 2016. ISBN 9785170966400

Три апельсина. Итальянские народные сказки. Санкт-Петербург, Москва: Речь, 2016. - 256 c. ISBN 978-5-9268-2298-1

ТРОЯнОВСКА, У. (2016): Мелкие бесы. Образы власти в творчестве Владимира Кантора. Olsztyn: „Przegląd Wschodnioeuropejski” 2016, nr VII/2, Wydawnictwo Uniwersytetu Warmińsko-Mazurskiego, c. 183-195.

Хитрый Камприано (Итальянские сказки). М.: Прогресс - Пермь: Урал-Пресс, 1993, 176 с., тираж 200000 экз. 
Хитрый Камприано : итальянские сказки / [перевод Натальи Михайловны Сухановой]; художник Юрий Николаев. Санкт-Петербург; Москва: Речь, 2018. - 170с.

Цветок папоротника: Польские сказки. Пер. Л. Пивоваровой. Чита: Кн. изд-во, 1960. $102 \mathrm{c}$.

Чешские и словацкие народные сказки. перевод с чешского и словацкого. М, «Художественная литература», 1990. 478 с. ISBN 5-280-00637-8

Чешские народные сказки. Государственное Издательство Детской Литературы Министерства Просвещения РСФСР, Москва-Ленинград, 1951. 104 с. ISBN не указан. Чешские народные сказки. Пер. и сост. М. Таловой. Москва: Гослитиздат, 1956. 280 с. Чешские сказки. Пер. с чеш. яз. Екатерины Бобраковой-Тимошкиной. Прага: Виталис, 2007. ISBN 978-80-7253-093-9

Чешские сказки. Сост. Иржи Горак. Пер. с чеш. Л. Рюриковой. Прага: АРТИЯ, 1974. $175 \mathrm{c}$.

чУковСКИЙ, К. Друзья героя волшебной сказки// Семья и школа. 1946, № 1-2. сс.2228.

ЧУПРИНИН, С. (2006, онлайн): Еше раз к вопросы о картографии вымысла. „Знамя” 2006, nr 11. Режим доступа: http://magazines.russ.ru/znamia/2006/11/ech19-pr.html [дата обращения 4.05.2018]

ШАЦкИЙ, О. Е. (онлайн): Сказка в оригинале и в переводе. In Начальная школа. 2013 (5), 108-112 [online]. Режим доступа: https://n-shkola.ru/storage/archive/14043781621689953961.pdf [дата обращения 29.4.2019]

ЭРБЕН, К.Я. (2013): Златовласка: чешские волшебные сказки. Для среднего школьного возраста. Пер. с чеш. Ольги Акбулатовой. Москва: Издательский дом Мещерякова, 2013. - 140, [3] с.

яХНИН, Л.Л. пер.(2011): Итальянские народные сказки. В моих краях. Москва: РИПОЛ классик, 2011 - 75, [4] с. ISBN 978-5-386-03194-7

яХНИН, Л.Л., пер. (2011): Итальянские народные сказки. т. 20. Москва: РИПОЛ классик, 2013- 48 с. ISBN 978-5-386-05560-8

яХНИН, Л.Л., пер. (2011): Итальянские народные сказки. т.27. Москва: РИПОЛ классик, 2012. - 33 с. ISBN 978-5-386-04861-7

\section{Электронные ресурсы}

Сайт: SkySlogan. URL: http://skyslogan.ru/dnevnik/896-otzyv-dlya-chitatelskogodnevnika-zlatovlaska.html Дата обращения: 18.09.18.

Сайт: Читательский дневник Насти Куликовой. URL: http://123456ant8.blogspot.ru/2013/11/blog-post_23.html Дата обращения: 18.09.18.

Сайт: Madame La Vie. URL:

http://madamelavie.ru/otzyvy/otzyv_erben_3_zolotyh_voloska Дата обращения: 18.09.18. 
Сайт: BabyBlog. URL: https://www.babyblog.ru/community/post/kids_books/3158499 Дата обращения: 18.09.18.

Сайт: Знания. URL: https://znanija.com/task/14267137 Дата обращения: 18.09.18.

Сайт: Лабиринт. URL: https://www.labirint.ru/reviews/goods/509618/ Дата обращения: 18.09.18.

Сайт: MKRU . URL: http://www.mk.ru/editions/daily/article/2007/12/21/63519-vgostyah-u-cheshskoy-skazki.html Дата обращения: 18.09.18.

Сайт: . URL: http://back-in-ussr.com/2014/07/v-gostyah-u-skazki-lyubimaya-peredachadetstva.html Дата обращения: 18.09.18.

Сайт: Назад в CCCP . URL: https://shkolazhizni.ru/culture/articles/61745/ Дата обращения: 18.09.18.

Сайт: Кинопоиск . URL: https://www.kinopoisk.ru/film/85047/ Дата обращения: 18.09.18.

Сайт: КиноМост . URL: http://www.kinomost.ru/index.asp?case=19\&num=7433 Дата обращения: 18.09.18.

Сайт: Кино-Театр.Py . URL: https://www.kino-teatr.ru/kino/movie/euro/32281/forum/ Дата обращения: 18.09.18.

Сайт: КиноПод . URL: http://kinopod.ru/video.html?id=9600 Дата обращения: 18.09.18.

Сайт: Livejournal. URL: https://nashe-detstvo.livejournal.com/316897.html Дата обращения: 18.09.18.

Сайт: Лабиринт . URL: https://www.labirint.ru/reviews/goods/546335/ Дата обращения: 18.09.18.

Сайт: Новая Литература.Литературно-художественный журнал. URL: http://newlit.ru/info/10/skazki_o_pane_tvardovskom_polskom_variante_fausta.html Дата обращения: 18.09.18.

Сайт: Большая онлайн-библиотека . URL: http://www.ereading.club/bookreader.php/130642/Polskie_narodnye_skazki.html Дата обращения: 18.09.18.

Сайт: Портал «Родон». URL: http://www.rodon.org/other/pns.htm; http://narodstory.net/poland.php; URL: http://skazkoved.ru/index.php?fid=1\&sid=17; https://libking.ru/books/child-/child-tale/180081-polskie-narodnye-skazki-polskienarodnye-skazki.html и др. Дата обращения: 18.09.18.

Сайт: Большая онлайн-библиотека. URL: http://www.ereading.club/bookreader.php/130642/Polskie_narodnye_skazki.html Дата обращения: 18.09.18.

Сайт: LiveLib. URL: https://www.livelib.ru/book/1000215012-polskie-narodnye-skazki Дата обращения: 18.09.18. 
Сайт: Лабиринт. URL: https://www.labirint.ru/reviews/goods/554414/ Дата обращения: 18.09.18.

Сайт: LiveLib . URL: https://www.livelib.ru/book/1000306360-italyanskie-skazkiantologiуа Дата обращения: 18.09.18.

Сайт: LiveLib . URL: https://www.livelib.ru/book/1002724784-hitryj-kamprianoitalyanskie-skazki-bez-avtora Дата обращения: 18.09.18.

Сайт: Лабиринт. URL: https://www.labirint.ru/reviews/goods/602117/ Дата обращения: 18.09.18.

Сайт: LiveLib . URL: https://www.livelib.ru/book/1000326131-skvoz-volshebnoe-koltsobritanskie-legendy-i-skazki-antologiya Дата обращения: 18.09.18.

\section{Источники на чешском языке:}

COLLODI, C. L. (1941): Nosáčkova dobrodružství: (Pinocchio.). V Červeném Kostelci: Josef Doležal, 1941. 140 - [IV] s. Doležalovy knihy pro mládež; Sv. 7.

COLLODI, C. L. (1988): Pinocchiova dobrodružství. Překlad Marie Holická a Jan Holický. Praha: Albatros, 1988.

HOLANEC, K. (2018): Collodiho Pinocchiova dobrodružství v českých překladech a literárních adaptacích [online]. 2018 [cit. 2019-05-01]. Dostupné z: https://dspace.cuni.cz/handle/20.500.11956/100502. Bakalářská práce. Univerzita Karlova, Filozofická fakulta, Ústav románských studií.

MANDYS, P. a kol. (2013): 2 x 101 knih pro děti a mládež: nejlepší a nejvlivnější knihy. Praha: Albatros, 2013. 430 s. ISBN 978-80-00-03336-5.

NOVÁKOVÁ, L. (2009): Proměny české pohádky: (k historii žánru ve čtyřicátých letech dvacátého století). Brno: Masarykova univerzita, 2009. 196 s. ISBN 978-80-210-5026-6.

TOLSTOJ, A. N. (1954): Zlatý klíček aneb Buratinova dobrodružství. Překlad Petr Denk. Praha: SNDK, 1954.

TOLSTOJ, A. N. (1970): Zlatý klíček aneb Buratinova dobrodružství. Překlad Hana Vrbová. Praha: Lidové nakladatelství, 1970.

\section{Источники на английском языке:}

BRYLINSKA A., SMITH H. (1919): Russian Fairy Tales. An Accented Russian Reader with Notes and Vocabulary. ed.A.Brylinska, H.Smith. L.-NY., Kegan Paul, Trench,Trubner \&Co, 1919.

CARPERNETER, Н. (1988, онлайн): Children's books; the subject was noses. „New York Times" 1988/11/13. Режим доступа:

https://www.nytimes.com/1988/11/13/books/children-s-books-the-subject-wasnoses.html [дата обращения 12.12.2018]. 
FINIST (1979): Finist the Bright-Eyed Falcon. A Russian Folk Tale. Moscow, Malysh, 1979.

FINIST (2000): Finist the Falcon Russian Folk Tales. Moscow, Raduga, 2000. ISBN 5-81940019-4

GUTERMAN N. (1945): Russian Fairy Tales. tr. by Guterman N. NY, Pantheon, 1945. ISBN не указан.

HELLMAN, B. (2013): Fairy Tales and True Stories. The History of Russian Literature for Children and Young People (1574-2010). Leiden, 2013.

LANG A. (онлайн) : The Fairy Books of Andrew Lang. The Story of King Frost. Режим доступа: http://www.gutenberg.org/files/640/640-h/640-h.htm\#2H_4_0020 [дата обращения 15.04.2018].

MCCRIMMON, B. (1988 онлайн): W.R.S.Ralston (1828-89): Scholarship and Scandal in the British Museum.British Library Journal, 1988, pp.178-198.

http://www.bl.uk/eblj/1988articles/pdf/article13.pdf [дата обращения 15.04.2018]

NISBET BAIN R. (1915): Russian Fairy Tales from the Russian by Polevoy by R.Nisbet Bain. NY, Frederick \&Stokes Company, 1915. - 252 p.

RALSTON W.R.S. (1873): Russian Folk-Tales. tr.W.R.S.Ralston. L., Smith, Elder\&Co, 1873. RUSSIAN FOLK TALES (1987): Russian Folk Tales. Moscow, Foreign Languages Publishing House, 1987.

SCHWAB YOCH (1934): Russian Folk Tales. Told by Yoch Schwab. Racine, Wisconsin, USA, 1934.

WHEELER P. (1957): Russian Wonder Tales. tr.Post Wheeler. NY. - L., Thomas Yoseloff.1957.

WILLIAMS P. (2000): Russian fairy tales. transl. by Paul Williams. St. Petersburg: P-2, 2000. ISBN 5-8194-0019-4

WORDS OF WISDOM (2000): Words of Wisdom. Russian Folk Tales from Alexander Afanasiev's Collection. Moscow, Raduga, 2000. ISBN 5-05-004635-1

WORLD OF TALES (онлайн) : World of Tales, 1. Режим доступа: https://www.worldoftales.com/European_folktales/English_folktale_8.html [дата обращения: 14.04.2018]

WORLD OF TALES (онлайн): World of Tales, 2. Режим доступа: https://www.worldoftales.com/European_folktales/English_folktale_21.html [дата обращения: 14.04.2018]

WORLD OF TALES (онлайн): World of Tales, 3. Режим доступа: https://www.worldoftales.com/European_folktales/English_folktale_29.html [дата обращения: 14.04.2018]

WORLD OF TALES (онлайн): World of Tales, 4. Режим доступа: https://www.worldoftales.com/European_folktales/English_folktale_1.html [дата обращения: 14.04.2018] 
WORLD OF TALES (онлайн): World of Tales, 5. Режим доступа: https://www.worldoftales.com/European_folktales/English_folktale_7.html [дата обращения: 14.04.2018]

WORLD OF TALES (онлайн): World of Tales, 6. Режим доступа: https://www.worldoftales.com/European_folktales/English_folktale_76.html [дата обращения: 14.04.2018]

WORLD OF TALES (онлайн): World of Tales, 7. Режим доступа: https://www.worldoftales.com/European_folktales/English_folktale_43.html [Дата обращения 16.04.2018]

WORLD OF TALES (онлайн): World of Tales, 8. Режим доступа: https://www.worldoftales.com/European_folktales/English_folktale_50.html [Дата обращения 16.04.2018]

WORLD OF TALES (онлайн): World of Tales, 9. Режим доступа: https://www.worldoftales.com/European_folktales/English_folktale_60.html [Дата обращения 16.04.2018]

ZAMCHUK A. (1998): Russian Folk Tales. Русские народные сказки. Transl. from Russ. by A. Zamchuk. Moscow: Literatura, 1998. ISBN 5-7842-0062-3

\section{Электронные ресурсы:}

https://fairytalez.com/region/russian

https://www.tor.com/2016/10/05/adapted-russian-fairy-tales-make-for-magical-novels

https://www.fictiondb.com/author/arthur-ransome favorite-russian-fairytales 547416 b.htm

https://www.csmonitor.com/Books/Book-Reviews/2016/0108/Vasilisa-the-Beautifulbrings-Russian-fairy-tales-to-life-with-gorgeous-new-illustrations

https://www.theguardian.com/childrens-books-site/2015/dec/02/grandfather-frost-andbaba-yaga-the-weird-wonderful-world-of-russian-fairytales

http://store.doverpublications.com/0486438937.html

https://www.amazon.com/Russian-Fairy-Pantheon-Folklore-Library/dp/0394730909 https://muse.jhu.edu/article/655156/summary

http://www.loyalbooks.com/book/Russian-Fairy-Tales

https://www.telegraph.co.uk/books/what-to-read/wolves-in-literature-katherinerundell/ 


\section{Источники на польском языке:}

AUGUSTYNIAK, A. (2016): Irena Tuwim. Nie umarłam z miłości. Biografia. Warszawa: Trzecia strona 2016, c. 272.

BALTYN, H. (2005, онлайн): Buratino - to je dobre. «Teatr Lalek» 2005, № 1. Режим доступа: http://encyklopediateatru.pl/artykuly/216307/buratino-to-je-dobre [дата обращения 12.12.2018].

BARDIJEWSKA, L. (2004 онлайн): Młodszy brat Pinokia. «Gazeta wyborcza» 2004.12.02, онлайн. Режим доступа: https://teatrlalka.pl/pl/spektakle/buratino [дата обращения 12.12.2018].

BETTELHEIM, B. (2010): Cudowne i pożyteczne o znaczeniach i wartościach baśni. tłum. D. Danek, Warszawa 2010.

BIAłEK, Z. (1979): Literatura dla dzieci i młodzieży w latach 1918-1939. Warszawa: Wydawnictwa Szkolne i Pedagogiczne 1979, c. 464.

BIBLIŃSKI, L. (1977): Zarys rozwoju ruchu wydawniczego w Polsce Ludowej. Warszawa: Wydawnictwa Naukowo-Techniczne 1977, c. 157.

Encyklopedia Teatru Polskiego (онлайн). Режим доступа: http://encyklopediateatru.pl [дата обращения 12.12.2018].

FRYCIE, S. (1988): Literatura dla dzieci i młodzieży w latach 1945-1970. Warszawa: WSiP 1988, т. 1., 511 c.

GALA, S. (1993): Apelatywno-antroponimiczne struktury z sufiksem -ajło. Łódź: „Acta Universitatis Lodziensis. Folia linguistica" 1993, № 27, c. 77-85.

JAMRÓZ-STOLARSKA, E. (2014): Serie literackie dla dzieci i młodzieży w latach 1945-1989. Produkcja wydawnicza i uksztattowanie edytorskie. Warszawa: SBP 2014, 180 c.

JĘDRYCH, K. (2014): Lektury w programach dla szkoły podstawowej z lat 1949-1989 [в:] Literatura dla dzieci młodzieży. T. 4, ред. К. Heska-Kwaśniewicz, K. Tałuć. Katowice: Wydawnictwo Uniwersytetu Śląskiego 2014, c. 205-224.

KADYKAŁO, A. (2014): Dzieciństwo jako rosyjski temat kulturowy w XX wieku, Kraków: Księgarnia Akademicka 2014, $622 \mathrm{~s}$.

KARDELA, D. (2014): Literatura rosyjska w Polsce. Próba charakterystyki produkcji i czytelnictwa w latach 2007-2012 [в:] Studia o Ksiqżce i Informacji. Wrocław: „Acta Universitatis Wratislaviensis" 2014, т. 33, c. 47-70.

KĘCZKOWSKA, В. (2004, онлайн): Rozmowa z Grzegorzem Leszczyńskim. „Gazeta wyborcza" 2004.11.19, онлайн. Режим доступа:

http://warszawa.wyborcza.pl/warszawa/1,34861,2402008.html [дата обращения 12.12.2018].

KRASIŃSKA, A. (2006): Recepcja utworów lekturowych w świetle wyników ankiety. Łódź: „Acta Universitatis Lodziensis” 2006, № 8, c. 571-592.

KRZEMIŃSKA, W. (1963): Literatura dla dzieci i młodzieży, Warszawa: SBP 1963, 183 c. 
LASKOWSKA, J. (2017): Rynek ksiq̨żki dla dzieci i młodzieży w Polsce, Gdańsk: „Jednak książki" 2017, № 7, c. 201-209.

MUSIOŁ, A. (2011): Przekłady ksiq̨żki zagranicznej w Polsce w latach 1991-2000 w świetle statystki, „Zagadnienia informacji naukowej” 2011, № 2, c. 89-101.

NUKAT. Katalog zbiorów polskich bibliotek naukowych (онлайн). Режим доступа: http://centrum.nukat.edu.pl/pl/ [дата обращения: 12.12.2018].

ODZIOMEK, М. (2017, онлайн): Buratino i niezwykły świat lalek. Premiera na jubileusz w Teatrze Lalek "Banialuka" w Bielsku-Białej, "Gazeta wyborcza” 2017.09.22, онлайн. Режим доступа: http://katowice.wyborcza.pl/katowice/7,35018,22402852,buratino-i-niezwykly-swiatlalek-premiera-na-jubileusz-w-teatrze.html [дата обращения 12.12.2018].

OLECH, J. (2011, онлайн): Pinokio w krainie odwyku. „Tygodnik powszechny” 2011, № 51. Режим доступа:

https://mediarodzina.pl/zasoby/attachments/pinokio_tyg_powszechny_18.12.2011.pdf [дата обращения 12.12.2018].

OSTASZ, M. (1999): Oblicze powojennej krytyki literatury dla dzieci i młodzieży 1945-1956. Kraków: Wydawnictwo Naukowe WSP 1999, c. 107.

PIETRZYCKA-BOCHOSIEWICZ, K. (2007) Poza granicami postmodernizmu. Późny debiut Władimira Kantora (cykl "autobiograficzny") [B:] Postmodernizm rosyjski i jego antyсурасје, ред. А. Gildner, M. Ochniak, H. Waszkielewicz, Kraków 2007, s. 141-153.

PIETRZYCKA-BOCHOSIEWICZ, K. (2010): Realizm chrześcijański Władimira Kantora. (Nowela "Śmierć emeryta") [в:] Idea i komunikacja w języku i kulturze rosyjskiej. Ред. А. Dudek, Kraków 2010, с. 213-222.

Ruch wydawniczy w liczbach 2005. Biblioteka Narodowa - Instytut Bibliograficzny 2006.

T. 5, 116 c.

Ruch wydawniczy w liczbach 2012, 2015, 2016

Ruch wydawniczy w liczbach 2015. Biblioteka Narodowa" 2016, T. 62, 62 c.

Ruch wydawniczy w liczbach 2016. Biblioteka Narodowa 2017, T. 63.136 c.

SADOWSKA, J. (2016): Literatura dziecięca w Polsce w świetle statystyki wydawniczej 1944-2012. Białystok: „Bibliotekarz Podlaski” 2016, № 2, c. 13-27.

SEMCZUK, M. (2005): Literatura rosyjska w Polsce po 1989 r. Warszawa: „Recepcja. Transfer. Przekład” № 1 (4), Wydawnictwo Uniwersytetu Warszawskiego 2005, c. 17-29.

SEMCZUK-JURSKA, M. (2010): Literatury i kultury wschodniosłowiańskie w Polsce - Rosja „Przegląd humanistyczny” 2010, т. 5/6, c. 67-82.

Słownik Języka Polskiego, PWN (онлайн). Режим доступа: https://sjp.pwn.pl [дата обращения 12.12.2018]

ŚWIETLICKI, M. (2014): „Dzieci imperium” - postkolonialny wymiar ukraińskiego rynku ksiq̨żki i pracy dla dzieci i młodzieży. Poznań: „Porównania” UAM 2014, № 15, c. 233-244.

TROJANOWSKA, U. (2016): Tymczasowy grób - pocigg. Podróż do i z Kolonii w twórczości Władimira Kantora. „Przegląd Wschodnioeuropejski” 2016, nr VII /1, Wydawnictwo Uniwersytetu Warmińsko-Mazurskiego, c. 247-259. 
TUWIM, I. (1981): Tajemnice warsztatu tłumacza. (Wizyta u Ireny Tuwim). „Sztandar Młodych" 1981.03.19.

WASZKIELEWICZ, H. (2015): Degradacja bohatera. Władimir Kantor „Krokodyl”, [в:] Bуć stwórca świata własnego. Szkice o współczesnej literaturze rosyjskiej, Kraków: Columbinum 2015, c. 107-119.

WIATROWA, H. (1973): Z dziejów recepcji w Polsce radzieckiej literatury dla dzieci i młodzieży. „Studia Rossica Posnaniensia” 1973, № 5, c. 23-32.

Wołodźko-BUTKIEWICZ, A. (2010): Badania nad literaturq rosyjskq XX wieku w okresie przeobrażeń (po 1990 roku). Nowe koncepcje periodyzacji, nowe podręczniki, „Przegląd humanistyczny" 2009, № 2, c. 1-10.

WORTMAN, S. (1958): Baśń w literaturze i życiu dziecka. Co i jak opowiadać?, Warszawa: SBP 1958, c. 205.

WOŹNIAK M., BIERNACKA-LICZNAR K., STANIÓW B. (2014). Przekłady w systemie małych literatur. O włosko-polskich i polsko- włoskich tłumaczeniach dla dzieci i młodzieży. Toruń: Wydawnictwo Adam Marszałek 2014, c. 290.

WOŹNIAK, M. (2012): Puchata przepustka do sławy. Pochwała Ireny Tuwim. „Przekładaniec” 2012, № 26, c. 115-134.

WOŹNIAK, M. (2013): Adaptacja w przekładach dla dzieci - gawęda terminologiczna. «Filoteknos» 2012, № 3, c 22-36.

WÓJCIK-DUDEK, M. (2012): Pinokio i Pippi, czyli o pożytkach błaznowania. O tym, na ile znamy bohaterów lektur. „Polski w Praktyce” 2012, № 2, c. 14-17.

WÓJCIKOWSKA-WANTUCH, P. (2018), Rosyjska bajka literacka na przełomie XX i XXI wieku. Nowy Sącz: Wydawnictwo PWSZ w Nowym Sączu 2018, 242 c.

ZYWERT, A. (2015): Czytajqc Rosję, współczesna proza rosyjska w Polsce: wybrane zagadnienia. Olsztyn: „Acta Neophilologica”, Wydawnictwo UWM 2015, c. 185-194. 


\section{Именной и предметный указатель}

\section{A}

адаптация, 31, 72

B

восприятие, 4, 6, 34, 61, 66, 73, 74, 88, 126

и

издание, 11, 34, 35, 36, 37, 38, 39, 40, 45, 49, 50, 52, 53, 59, 69, 70, 72, 83, 89, 90

имя, 10, 11, 12, 13, 14, 15, 31, 32, 35, 40, 42, 51, 79, 93

$\mathbf{K}$

Кантор, Владимир , 110, 111, 113, 114, 115, 116, 118, 120, 122, 123, 124, 125, 127

Коллоди, Карло, 6, 55, 56, 57, 58, 61, 62, 63, 64, 65, 66, 72, 74, 80, 81, 82, 85, 86, 87, 91, 126,127

M

Маршак, Самуил, 34

Михалков, Сергей, 75

H

название, 9, 10, 11, 12, 14, 18, 20, 24, 27, 31, 33, 44, 56, 78, 86, 90

0

отношение, 36, 40

$\Pi$

перевод, 6, 7, 9, 11, 12, 13, 14, 20, 21, 23, 24, 25, 28, 29, 33, 39, 48, 49, 51, 56, 57, 61, 62,

$63,69,72,73,75,78,79,80,81,82,86,88,89,90,91,92,126,134,138$

переводчик, 8, 9, 10, 11, 12, 13, 14, 17, 18, 19, 21, 22, 23, 24, 25, 28, 34, 49, 61, 63, 77,

$78,79,81,89,90$

переложение, 56

повесть, 64, 83, 84, 110, 111, 112, 115

Пушкин, Александр 75, 115

\section{$\mathbf{P}$}

реалия, 17, 19, 26, 29

роман, 67, 68, 113, 114, 115, 116, 120, 121

Россия, 70, 126 
сказка, 4, 5, 10, 11, 12, 15, 23, 30, 31, 32, 33, 34, 36, 37, 39, 40, 41, 46, 48, 50, 51, 54, 55,

$65,66,74,83,84,85,92,93,111,115,121,126,127,133,135,136$

английская, 10, 24, 30, 51, 52, 53, 54

итальянская, 34, 46, 48, 49, 50, 53, 82

литературная, 6, 57, 94, 127

народная, 8, 20, 33, 34, 36, 40

польская, 43, 45, 46, 50, 53

чешская, 39,40

Толстой,

Алексей Николаеви, 68, 70, 83, 84, 86, 88, 91

Лев Николаевич, 58, 114

4

Чуковский, Корней, 34, 55, 68 


\section{Сказка - вопросы перевода и восприятия}

Mgr. Eva Kudrjavceva Malenová, Ph.D.

Maria Raviljevna Nenarokova

Paulina Wójcikowska-Wantuch

Giulia De Florio

Published by Masaryk University Press, Žerotínovo nám. 617/9, 60177 Brno, CZ Cover design Mgr. Jana Nedomová, Ph.D.

First electronic edition, 2019

ISBN 978-80-210-9344-7

https://doi.org/10.5817/CZ.MUNI.M210-9344-2019 


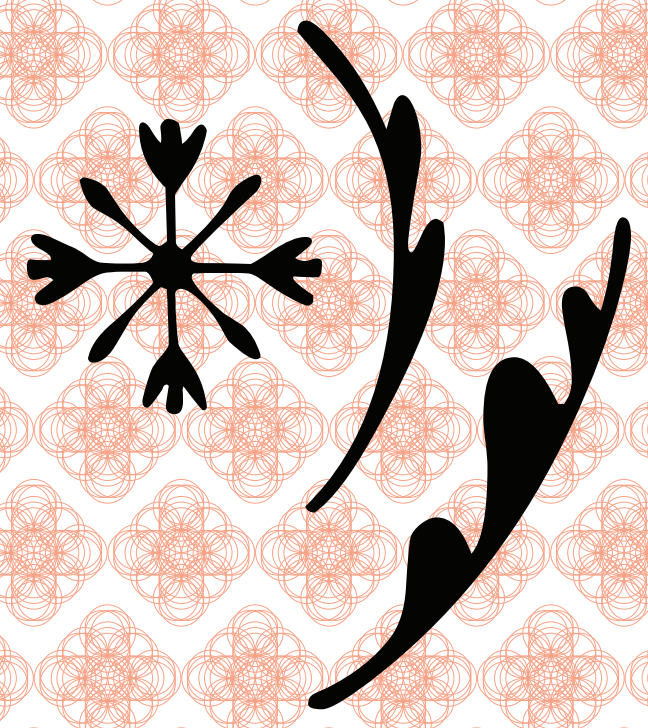

II U II I

II U II I

PED

PRESS 